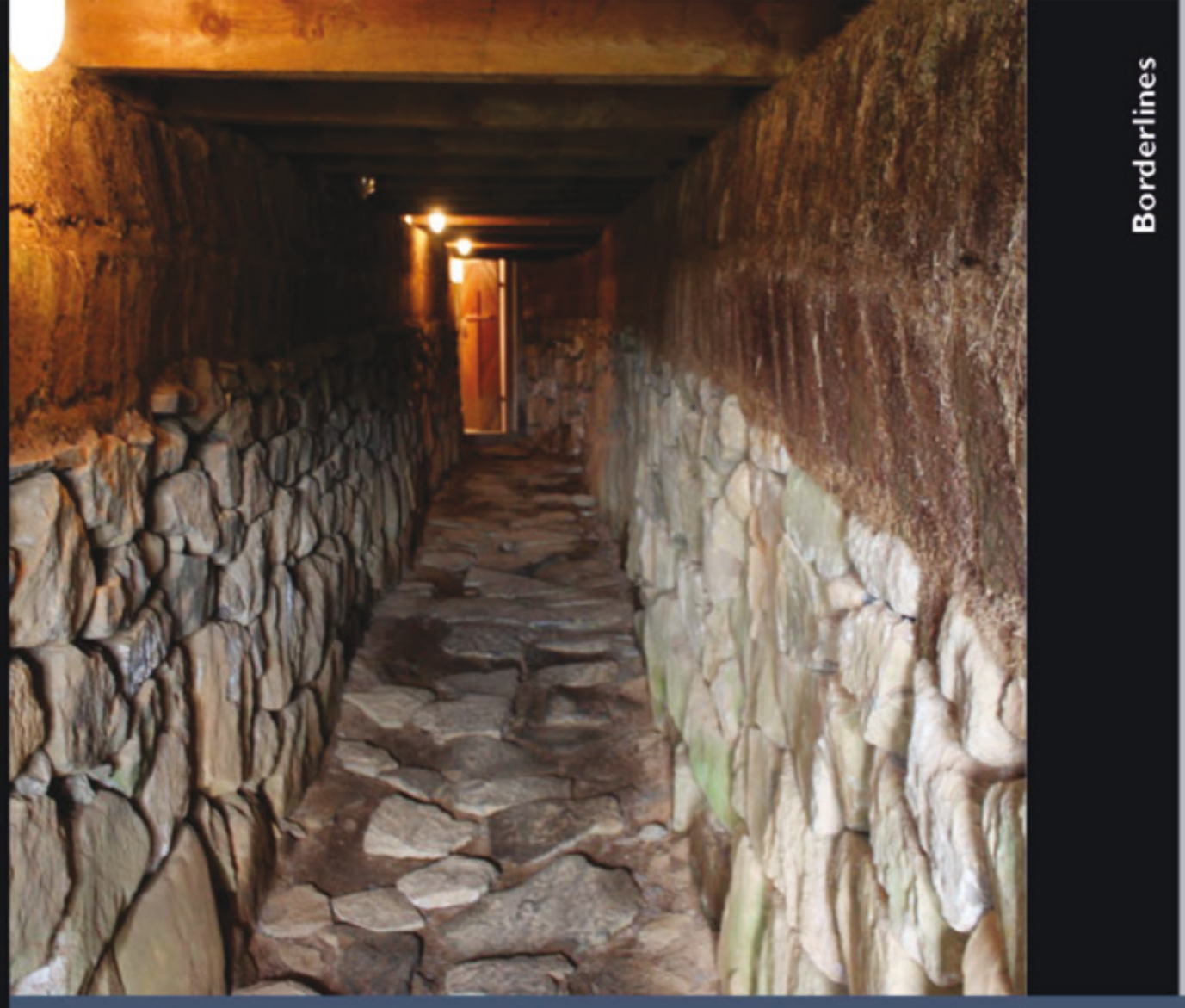

\title{
ICELANDIC FOLKLORE AND THE CULTURAL MEMORY OF RELIGIOUS CHANGE
}

by

ERIC SHANE BRYAN

ARChumanities press 



\section{ICELANDIC FOLKLORE}

AND THE CULTURAL MEMORY OF RELIGIOUS CHANGE 


\section{BORDERLINES}

Borderlines welcomes monographs and edited collections that, while firmly rooted in late antique, medieval, and early modern periods, are "edgy" and may introduce approaches, methodologies, or theories from the social sciences, health studies, and the sciences. Typically, volumes are theoretically aware whilst introducing novel approaches to topics of key interest to scholars of the pre-modern past. 


\title{
ICELANDIC FOLKLORE
}

\section{AND THE CULTURAL MEMORY OF RELIGIOUS CHANGE}

\author{
by \\ ERIC SHANE BRYAN
}

ARChUYARITIES PRESS 
We have all forgotten our names.

-G. K. Chesterton

This work is licensed under Creative

Commons licence CC-BY-NC-ND 4.0.

\section{British Library Cataloguing in Publication Data}

A catalogue record for this book is available from the British Library.

\section{(C) 2021, Arc Humanities Press, Leeds}

The author asserts their moral right to be identified as the author of this work.

Permission to use brief excerpts from this work in scholarly and educational works is hereby granted provided that the source is acknowledged. Any use of material in this work that is an exception or limitation covered by Article 5 of the European Union's Copyright Directive (2001/29/EC) or would be determined to be "fair use" under Section 107 of the U.S. Copyright Act September 2010 Page 2 or that satisfies the conditions specified in Section 108 of the U.S. Copyright Act (17 USC §108, as revised by P.L. 94-553) does not require the Publisher's permission.

ISBN (HB): 9781641893756

ISBN (PB): 9781641894654

eISBN (PDF): 9781641893763

\section{www.arc-humanities.org}

Printed and bound in the UK (by CPI Group [UK] Ltd), USA (by Bookmasters), and elsewhere using print-on-demand technology. 


\section{CONTENTS}

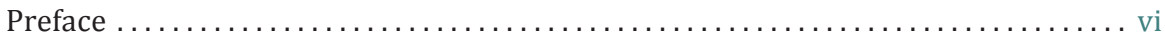

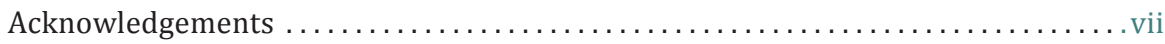

Introduction: Stories, Memories, and Mechanisms of Belief $\ldots \ldots \ldots \ldots \ldots \ldots \ldots 1$

Chapter 1. The Dead Bridegroom Carries Off His Bride: Pejoration

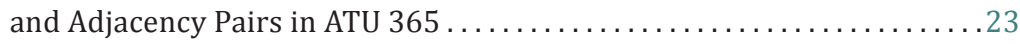

Chapter 2. The Elf Woman's Conversion: Memories of Gender and Gender Spheres..................................

Chapter 3. The Fylgjur of Iceland: Attendant Spirits and a Distorted

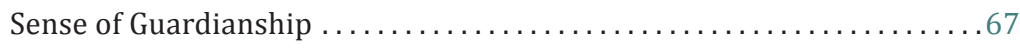

Chapter 4. The Elf Church: Memories of Contested Sacred Spaces............... 89

Chapter 5. The Stupid Boy and the Devil: Sæmundur fróði Sigfússon, Magic, and Redemption .............................. 117

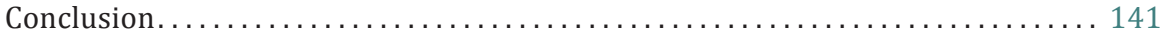

Select Bibliography....................................... 149

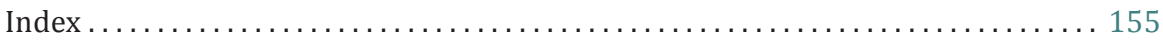




\section{PREFACE}

THERE IS SOMETHING inherently offensive about the study of folklore. Inevitably, the student of folklore becomes either an imposter, an opportunist, or (most often) both, because they presume to project objectivity upon something that was never meant to be objectified. The search for such objectivity, further, is an endeavour doomed from the start. Folk stories, as one part of folklore, can never be objectified in the way the student would hope; the folk story is the action being done, not an object upon which something is done. Once it becomes the object, it ceases to be folklore. Scholars normally call this kind of agency performance, yet when it is objectified, the performance must be torn from both the performers of the action-the storytellers, the singers, the dancers, the actors-and the recipients of the action-the hearers, the audience, the cultural life in which the folklore acts. Nor is it enough for the student of folklore to remain quiet and still and allow the story to speak for itself, without interruption or analytical lens, because it is not possible to hear or read any story without also becoming a participant in it. The human mind will always participate in the story being told. This much, at least, we know for sure. The best the student of folklore can hope for, perhaps, is to participate in a specific way: by telling the story ... and then by telling the story of the story. This volume represents an effort to participate thus in five of the greatest stories ever told in the northern world.

This book attempts to understand the origins and development of religious belief in Iceland and greater Scandinavia through the lenses of five carefully selected Icelandic folktales collected in Iceland during the nineteenth century. Each of these five stories has a story of its own: a historical and cultural context, a literary legacy, influences from beliefs of all kinds (orthodox and heterodox, elite or lay), and modalities (oral or written) by which the story was told. These factors leave an imprint-sometimes discernable, sometimes not-upon the story, and when that imprint is readable, the legacies and influences upon these stories come alive to illuminate a tapestry of cultural memory (that is, a society's perception of itself, its past, and its prospects for the future) and cultural development that might otherwise be hidden from the reader's eyes. So much is the aim of this book: to tell the story of five great stories.

It remains only to be added that I hope any of the offences that inevitably accompany a study of folklore will here be forgiven by virtue of the deep appreciation and wonder I hold for these (and all) Icelandic folktales, and for the people and the land from which they come.

Eric Shane Bryan

Saint Louis, Missouri

February 14, 2020 


\section{ACKNOWLEDGEMENTS}

I HAVE ACCRUED many debts during the course of writing this book. I must first thank professors Thomas A. Shippey and Paul Acker for their encouragement and correction of the earliest version of this book. I am also deeply indebted to Professor Terry Gunnell at the University of Iceland, who was a wonderful mentor during my time as a Fulbright researcher and who has continued to be a source of support, encouragement, and friendship throughout this entire process. I also offer very special thanks to Professor Shaun F. D. Hughes for his encouragement even at the earliest stages of this project and for his willingness to review the final version of this book. His keen eye has saved me from more embarrassing mistakes than I care to count. I am also grateful to Gísli Sigurðsson, Ármann Jakobsson, Simon Bronner, and Anne Cotterill—all of whom read drafts of various chapters of this work and offered both encouragement and correction where needed-and to Margaret Cormack, who was always willing to discuss ideas related to this work. Special thanks to Bruce Smith, who has been a careful reader and source of constant encouragement for this and many other endeavours. I also extend my gratitude to the Fulbright Program, which gave me my first opportunity to travel and study in Iceland, as well as the American-Scandinavian Foundation, the College of Arts, Sciences, and Business at Missouri University of Science and Technology, and the Missouri Research Board, for granting financial support for travel and study in Iceland. I offer special thanks to the Árni Magnússon Institute in Iceland, as well as to the many kind and generous scholars there who permitted me to study alongside them at various times from 2005 to the present. I am also very grateful to Robert Bjork, Anna Henderson, and the other editors at Arc Humanities Press for their tireless efforts during the review and editorial process. Thanks also to my department chair at Missouri University of Science and Technology, Kristine Swenson, who permitted me to run off to Iceland on various research trips whenever I could find the time and money. Last and most important, thanks to my family—my beloved wife, Emily; my son, Everett; and my daughters Bryndís (who was born in Iceland on one of my research trips) and Adelaide-for their love, support, and patience throughout the writing of this book. 



\section{INTRODUCTION: STORIES, MEMORIES, AND MECHANISMS OF BELIEF}

\section{Cultural Memory and the Development of Belief}

This book traces the origins and development of five post-Reformation Icelandic folktales in an attempt to understand cultural memories of Christianization and Reformation in Iceland and elsewhere in the North. While the study of cultural memory has in recent years become a keen interest for scholars of the medieval North, ${ }^{1}$ relatively little attention has been given to the cultural memory of the post-medieval period, and even less consideration has been given to what post-medieval folk stories might contribute to memory studies. ${ }^{2}$ The present book seeks to fill that gap by drawing connections between Icelandic folktales collected during the eighteenth and nineteenth centuries-with special attention given to Jón Árnason's vast collection of tales published in 1862 and 1864-and their earlier counterparts in Old NorseIcelandic sagas and Eddic poetry. The five Icelandic folktales that anchor the following chapters were selected because they meet criteria that set them apart as especially useful lenses through with to view the diachronic developments of cultural memory in Iceland: (1) each tale has deep and discernible roots in literary history, folkloristic development, and theological undercurrents not only in Iceland but throughout Scandinavia; (2) each displays a distinct concern for one of five fundamental aspects of religious belief (respectively, death and mourning, gender, supernatural attendance, sacred spaces, and the renewal of self); and (3) the development of each tale shows evidence of a demonstrable transformation over time of how those fundamental aspects of belief are perceived within cultural memory. Since discernible vectors can

I For some important examples, see Sverrir Jakobsson, "Conversion and Cultural Memory in Medieval Iceland," Church History 88 (2019): 1-26; Handbook of Pre-Modern Nordic Memory Studies: Interdisciplinary Approaches, ed. Jürg Glauser, Pernille Hermann, and Stephen A. Mitchell, 2 vols. (Berlin: de Gruyter, 2018); Minni and Muninn: Memory in Medieval Nordic Culture, ed. Pernille Hermann, Stephen A. Mitchell, and Agnes S. Arnórsdóttir (Turnhout: Brepols, 2014); and "Memory and Remembering: Past Awareness in the Medieval North," ed. Pernille Hermann and Stephen A. Mitchell, special issue, Scandinavian Studies 85, no. 3 (2013).

2 Important exceptions to this rule are Agnes S. Arnórsdóttir's "Cultural Memory and Gender in Iceland from Medieval to Early Modern Times," Scandinavian Studies 85 (2013): 378-99; Sofie Vanherpen's “Remembering Auðr/Unnr djúp(a)uðga Ketilsdóttir: Construction of Cultural Memory and Female Religious Identity," Mirator 14 (2013): 61-78; and my "Prospective Memory of Death and the Afterlife," Neophilologus 103 (2019): 543-60. 
be articulated from these tales backwards into literary history and cultural memories of the past, ${ }^{3}$ they illuminate the development of Icelandic cultural memory from the medieval to the post-medieval period, for, as will be argued in the following pages of this book, folktales do not change without purpose; they rather transform in response to the cultural, religious, and interpersonal influences around them. These narratives can therefore reveal elements of a society's cultural development that would otherwise go unnoticed if one looks only at more traditionally conceived historical evidence.

More specifically, viewing Icelandic cultural memory through the lens of folklore helps illuminate some of the most significant and long-standing questions regarding the relationship between the beliefs of the lay person and the doctrines of orthodoxy: How close are the beliefs of the lay person to the doctrines of the Church? What is the relationship between post-conversion Christian (and, later, post-Reformation Lutheran) beliefs and the pre-Christian pagan beliefs of the medieval North? And, finally, How accurately do later, post-conversion (or post-Reformation) folk narratives represent the convictions and beliefs of those persons outside the realm of the elite (literate) classes? As Stephen A. Mitchell recently stated, "Folklore and 'memory' (in all its different varieties) are largely inseparable, even, one might say, helpmates." ${ }^{4}$ As helpmates to memory, then, the five stories (and the corresponding aspects of belief) that anchor the following chapters allow for a comparative, diachronic assessment of the developing cultural memory of belief in Iceland. The following assessment of these five anchor narratives proceeds by considering them on three axes: (1) connections with international folktale types and motifs; (2) connections with theological and historical events that occurred in Iceland and beyond as the region experienced Christianization and Reformation; and (3) connections to the literature and poetry of the Old Norse/medieval Icelandic world. An assessment along these three axes enables a test of the hypothesis that, while it may reasonably be expected that fringe and heterodox beliefs as represented in these folktales would be an attempt to undermine or outright reject established religious institutions, these indications of heterodoxy instead reflect an inclination to create a unified belief system that incorporates both the institutional (i.e., Christian) religious doctrine and the native landscape of belief.

The specific outcomes of this assessment and how they relate to the above hypothesis will be borne out in the subsequent chapters of this book. The remainder

3 Gísli Sigurðsson takes up a similar perspective in consideration of the value of Snorri Sturluson's Prose Edda, whose composition (it may be added here) has a similar makeup as might be observable in a later collection of folktales. See Gísli Sigurðsson, "Past Awareness in Christian Environments: Source-Critical Ideas about Memories of the Pagan Past," Scandinavian Studies 85 (2013): 400-10 (especially 408-10).

4 Stephen A. Mitchell, "Folklore Studies," in Handbook of Pre-Modern Nordic Memory Studies: Interdisciplinary Approaches, ed. Jürg Glauser, Pernille Hermann, and Stephen A. Mitchell, 2 vols. (Berlin: de Gruyter, 2018), 1:101. See also Mitchell's “Orality and Oral Theory," in Handbook of Pre-Modern Nordic Memory Studies: Interdisciplinary Approaches, ed. Jürg Glauser, Pernille Hermann, and Stephen A. Mitchell, 2 vols. (Berlin: de Gruyter, 2018), 1:120-31. 
of this introductory chapter will be dedicated to establishing the scope and scholarly context for the following chapters, particularly regarding three key factors: a framework for cultural memory and its application to Old Norse-Icelandic studies, a brief outline of Reformation history and theology relevant to post-Reformation folk narratives, and consideration of the folklore sources that make up the heart of this study.

\section{Cultural Memory in Iceland and Abroad}

The question of a tension between lay and ecclesial beliefs throughout these religious developments has long been a point of contention amongst scholars. In the broader context of medieval and early modern Europe, scholars have been divided on the question of how closely the beliefs and cultural views of the elite aligned with those of the masses. Some scholars, on the one hand, argue for a stark differentiation between a clerical elite and a much larger "folk" culture, ${ }^{5}$ while others vigorously reject the notion of a conflictive polarity between two cultures, arguing that the sources that would support such a polarity are in fact scarce and that many more reflect a culture struggling to understand Christianity rather than oppose it. ${ }^{6}$ Recently, Richard Firth Green has argued for a "state of hostility, or at least deep suspicion, existing between representatives of the great tradition [of the educated few] and those espousing such aspects of the little tradition [of the uneducated masses] as a belief in fairies." ${ }^{\prime 7}$ In fact, argues Green, "vernacular culture (that is to say, the culture of the little tradition) was far from having lost its power to resist in the Middle Ages despite the church's having stepped up its campaign against it." ${ }^{8}$ The present study of Icelandic folklore bears relevance on this debate, which has been ongoing for several decades, ${ }^{9}$ because

5 Conceptually, at least, this historical anthropological approach is not inherently partisan on the issue of elite versus folk beliefs, but suggests that historiography can benefit from applying methodologies from the fields of anthropology, art history, literature, and folkloristics.

6 This view is chiefly represented in John Van Engen's essay "The Christian Middle Ages as an Historiographical Problem," American Historical Review 91 (1986): 519-52, which outlines the origins and development of the issue. See also Alexander Murray, "Confession as a Historical Source in the Thirteenth Century," in The Writing of History: Essays Presented to Richard William Southern, ed. R. H. C. Davis and J. M. Wallace-Hadrill (Oxford: Clarendon, 1981), 275-322.

7 Richard Firth Green, Elf Queens and Holy Friars: Fairy Beliefs and the Medieval Church (Philadelphia: University of Pennsylvania Press, 2017), 50. Green aims to nuance the notion of a high and low culture, or, as Peter Burke puts it, the "great" and "little" traditions. See Green, Elf Queens, 42-51, for more on this discussion.

8 Green, Elf Queens, 49.

9 For an appraisal of the relationship between this approach and Nordic memory studies, see Bjørn Bandlien, "History," in Handbook of Pre-Modern Nordic Memory Studies: Interdisciplinary Approaches, ed. Jürg Glauser, Pernille Hermann, and Stephen A. Mitchell, 2 vols. (Berlin: de Gruyter, 2018), 1:303-317 (304-5), but note that Norse proponents of the Schmitt/Le Goff perspective rarely acknowledge the reservations registered by Van Engen, "The Christian Middle Ages," and others noted in footnote 6 above. 
of the persistent question of whether medieval and post-medieval Icelandic folklore may be indicative of-if not pre-Christian then at least-heterodox Icelandic beliefs. Jean-Claude Schmitt's enticing reference to "the complex makeup of medieval culture," and "the heritage that gave birth to it: the legacies of Greco-Roman paganism ... or the 'barbarian' legacies that were brought back through the migrations of Germanic peoples and that were integrated into Christendom during the first millennium" ${ }^{10}$ may be an exciting prospect, but as John Van Engen has demonstrated, it is nearly impossible to show evidence of the kind of definitive historical connections between paganism and Christianity alluded to by Schmitt. ${ }^{11}$

The study of cultural memory has provided some useful new tools to the problem, largely due to its recognition of diverse modalities of transmitting cultural memories, along with the notion of an internal/external context for those memories. Early on, James Fentress and Chris Wickham emphasized the transmissible quality of "social memory,"12 to use their terminology, saying that in order for a memory to be "social," it must have some modality by which it can be felicitously distributed throughout a society. ${ }^{13}$ Both narrative and visual modalities function as viable means of such transmission, but in both cases the memory conveyed (rather than the medium of transmission) must remain the central subject of study. ${ }^{14}$ To understand the modality of transmission, Fentress and Wickham envisioned an internal and external context in which cultural memory might be transmitted. The external context depends upon a specific social environment and therefore upon those cultural phenomena which are meaningful to a particular society at a particular time. The internal context, which depends more heavily upon imagery and thematic coherence, tends to remain free of a specific social context. ${ }^{15}$

For instance, one noteworthy site of the internal/external contexts of Icelandic cultural memories may be found in Ari Porgilsson's (1068-1148) well-known deference to bishops Porlákur and Ketill and the priest Sæmundur fróði (the wise) at the start of Íslendingabók (The Book of the Icelanders). As Sîan Grønlie points out, though Íslendingabók may be called history by genre, "Ari creates a myth of origins for the

10 Jean-Claude Schmitt, Ghosts in the Middle Ages: The Living and the Dead in Medieval Society, trans. Teresa Lavender Fagan (Chicago: University of Chicago Press, 1998).

I I Van Engen, “The Christian Middle Ages," 532.

12 For an effective discussion of the relationships between schools of social/cultural memory, see Alan Kirk, "Social and Cultural Memory," in Memory, Tradition, and Text: Uses of the Past in Early Christianity, ed. Alan Kirk and Tom Thatcher (Atlanta: Society of Biblical Literature, 2005), 1-24.

13 See especially chapter 2 of James Fentress and Chris Wickham, Social Memory: New Perspectives on the Past (Oxford: Blackwell, 1992), 41-86.

14 See Carole L. Crumley, "Exploring Venues of Social Memory," in Social Memory and History: Anthropological Perspectives (Walnut Creek: AltaMira, 2002), 39-52, for more on ways of understanding the different media (venues) of cultural memory.

15 Fentress and Wickham, Social Memory, 72. Fentress and Wickham employ an analysis of epic narratives and what they call "fairy tales" to exemplify their distinctions. See below for my discussion of genre, however. 
Icelanders involving migration over the sea and settlement in a 'promised' land."16 Presuming this "myth of origins" was taken up by the Icelandic people, it would have been woven into the tapestry of the Icelandic cultural memory and carried forward through various means, and not just historical sources, like Ari's, but through a variety of modes of communication and memory. While it may be difficult to verify definitively that Ari's view of early Icelandic history is accurate, he is clearly concerned with (at least the appearance of) accuracy, for he refers to what would amount to the intellectual elite of Iceland at the time in the persons of Porlákur, Ketill, and Sæmundur. All three were well known for their wisdom and learning and thus constitute an appeal to an external context for the cultural memory Ari means to communicate. ${ }^{17}$ Notably, even historians outside of Iceland during Ari's time took notice of the care Icelanders had for history. Ármann Jakobsson notes that the great medieval historian Saxo Grammaticus (ca. 1160-1220) acknowledged Icelandic historians for their ability. ${ }^{18}$ Saxo says he has "scrutinized [Icelanders'] store of historical treasures and composed a considerable part of [his] present work by copying their narratives, not scorning, where I recognized such skill in ancient lore, to take these men as witnesses."19 This acumen for composing and preserving "historical treasures" and "ancient lore" does not necessarily imply that Icelandic histories are more accurate than others (as Saxo seems to deduce), yet it cannot be denied that Icelanders, from the earliest recorded writings about themselves, especially valued the very types of stories and sense of self that make a study of cultural memory possible. Ari's appeal to authority in his preface to Íslendingabók also represents an attempt to establish a connection with the external context in Iceland, specifically, as he aims to gain the approval of those considered wise in the country.

Sverrir Tómasson has pointed out that Ari's appeal to church authority and his pursuit of accuracy reflect a common medieval topos evident in many such historical writings outside Iceland..$^{20}$ Even though they are derived from outside Iceland, these

16 Sîan Grønlie, "Introduction," in Íslendingabók = Kristni Saga (The Book of the Icelanders = The Story of Conversion), trans. Sîan Grønlie (London: Viking Society for Northern Research, 2006), xxv. See also Stephen A. Mitchell's "The Mythologized Past: Memory in Medieval and Early Modern Gotland," in Minni and Muninn: Memory in Medieval Nordic Culture, ed. Pernille Hermann, Stephen A. Mitchell, and Agnes S. Arnórsdóttir (Turnhout: Brepols, 2014), 155-74.

17 These must be Porlákur Runólfsson, bishop of Skálholt (1118-1133) and Ketill Porsteinsson, bishop of Hólar (1122-1145). Sæmundur inn fróði (the wise) was a priest at Oddi, in southern Iceland, who was well known for his learnedness and wisdom. He became an important figure in history and lore, and would feature in the story entitled "The Stupid Boy and the Devil," discussed in chapter 5 , below.

18 See Ármann Jakobsson, A Sense of Belonging: Morkinskinna and Icelandic Identity, c. 1220, trans. Fredrik Heinemann (Odense: University Press of Southern Denmark, 2014), 287.

19 Saxo Grammaticus, The Histories of the Danes, Books I-IX, ed. Hilda Ellis Davidson, trans. Peter Fisher (Cambridge: Brewer, 1979), 5.

20 Sverrir Tómasson, Formálar íslenskra sagnaritara á miðöldum, Rannsókn bókmenntahefðar, Stofnun Árna Magnússonar á Íslandi, Rit 33 (Reykjavík: Stofnun Árna Magnússonar, 1988), 155-57. Siân Grønlie directs readers to this work in n. 4 of her translation of Íslendingabók. 
topoi represent an internal context that remains free of any dependence upon the immediate external context localized in Iceland. The presence of such topoi not only indicates the author's concern with literary custom of the day (one modality of cultural memory), but it also speaks to a concern with the ethos with which his expressly Icelandic audience will receive his work. For the same reasons that modern scholars include footnotes and page references, Ari gives deference to the intellectual standards of his day. Despite Sverrir Tómasson's keen observations, if Ari were seeking to impress an international audience, he would have almost certainly written in Latin, and he would certainly have done much more to couch the Icelandic story within the context of global Christian missionary initiatives rather than the local. ${ }^{21}$ In other words, the appeal to an international topos represents an internal context, but the manner in which he applies that topos (via a localized appeal to Icelandic figures) represents an external context. Both in this instance and in more general terms, this type of interdependence upon internal and external context results in a close relationship between the communicator of the cultural memory (be they saga writer, oral storyteller, or historian) and the audience. No doubt, as Gísli Sigurðsson recently stated, "The tellers and writers of stories about the past shape the ideas of their audiences and readers about what happened, how it happened, and why it happened,"22 yet the authors of such stories (or histories, in the case of Ari) must also gain and sustain the respect of their audience in order to articulate such performative acts as Gísli describes. ${ }^{23}$

Fentress and Wickham's presentation of internal and external contexts also illuminates one of the most important attributes of cultural memory: malleability. Cultural memories are often constructed or reconstructed decades or even centuries after the events they purport to recall, and their shaping is influenced by all manner of contemporary forces, whether political, religious, or other cultural currents. The reasons why a particular society might permit or even encourage the shaping or reshaping of certain aspects of its cultural memories offer a good opportunity for an analysis of cultural development. A study of cultural memory acknowledges a reciprocal relationship between memory and the external cultural and historical context from which it draws its vitality, yet it does not depend wholly upon that relationship for its textual analysis; it also asserts itself upon that context. This allows for the presence of cultural differences to be indicated by a study of cultural memory without the need for claiming something on a historical level. In short, cultural memory is not history, and a

2I See Grønlie, "Introduction," xxv-xxvi for a useful defence of this point.

22 Gísli Sigurðsson, "Constructing a Past to Suit the Present: Sturla Pórðarson on Conflicts and Alliance with King Haraldr Hárfagri," in Minni and Muninn: Memory in Medieval Nordic Culture, ed. Pernille Hermann, Stephen A. Mitchell, and Agnes S. Arnórsdóttir (Turnhout: Brepols, 2014), $175-96$ at 175.

23 See J. L. Austin, How to Do Things with Words, ed. J. O. Urmson (Oxford: Oxford University Press, 1965), 14-15, where Austin discusses the need for performatives to meet certain felicity conditions, without which a performative would not be valid. 
study of cultural memory is not historiography. Cultural memory is rather an image of history preserved, accurately or not and by various modalities ${ }^{24}$ of the transmission of meaning, within a culture. Sverrir Jakobsson has recently explored these characteristics of cultural memory with respect to Old Norse-Icelandic historical narratives about the conversion and Christianization of Iceland. Sverrir suggests that the Old Norse-Icelandic histories of conversion in Iceland are concerned not only with the establishment of church institutions and authority but "also with the development of Christian identity in Iceland and the question of whether this new religion should be an elitist endeavor connected with a limited group of people or it implied a genuine conversion of the masses." 25 Sverrir concludes that while the earlier accounts of conversion attribute the change in religion to an individual or a few people, subsequent accounts became increasingly inclusive until conversion was represented in the latest versions as a nationwide phenomenon, including both the elite and humble. ${ }^{26}$

Iceland's conversion from paganism to Christianity ${ }^{27}$ would clearly have been an especially important part of the cultural memory. This period marked a time when writing became an increasingly significant medium for narrative transmission,

24 Recently, Old Norse scholars Pernille Hermann, Stephen A. Mitchell, and Agnes S. Arnórsdóttir have taken up this notion (though they use their own terminology) of the various modalities of conveying meaning. These scholars seek to understand premodern Nordic memory from a variety of frameworks and genres: myth, history, poetry, and saga are all considered, such that their work perceives how memory is shaped, how it functions, and how is depicted in medieval Icelandic and Nordic culture. Their volume, Handbook of Pre-Modern Nordic Memory Studies, referenced several times in this Introduction, brings together a wide array of interdisciplinary approaches to the conception of memory, cultural and otherwise, in the medieval North. While memory studies do not oppose historical approaches, they pursue a different objective than does historiography. Whereas historiography seeks an account of events as they happened, memory studies pursue an understanding of how events are remembered. A review of this expansive two-volume reference work would be impossible here, but, as the foreword to the first volume states, the goal of the study is to "scrutinise the ways in which memory, remembrance, commemoration, and other forms of anamnesis (at individual, collective, and cultural levels) mattered to pre-modern Nordic cultures" (Handbook of Pre-Modern Nordic Memory Studies, 1:xvii). This volume will be of great use to scholars of memory in the medieval North. Of special value may be the second volume, which includes a wealth of interesting primary texts and images relevant to memory studies: Minni and Muninn.

25 Sverrir Jakobsson, "Conversion and Cultural Memory," 2.

26 Sverrir Jakobsson, "Conversion and Cultural Memory," 26.

27 The conversion and Christianization of Iceland have been thoroughly discussed in scholarship and requires no further scrutiny here. Aspects of conversion and Christianization relevant to the content of the following chapters will be addressed where appropriate. For the most accessible discussion of conversion and Christianization, see Orri Vésteinsson, The Christianization of Iceland (Oxford: Oxford University Press, 2000). For a broader Scandinavian context, see Anders Winroth, The Conversion of Scandinavia: Vikings, Merchants, and Missionaries in the Remaking of Northern Europe (New Haven: Yale, 2012); for a discussion of sources relevant to conversion, see Siân Duke, "Kristni Saga and Its Sources: Some Revaluations," Saga Book 25 (2001): 346-66. Further discussion of Reformation and Lutheranization is given below. 
but oral transmission remained vital to the communication of cultural memory. ${ }^{28}$ Christianization was in full swing in Iceland by 1100 , and it obviously had a tremendous impact on how and whether various pre-Christian folk beliefs persisted, due both to the increasing emphasis on written sources and the cultural dissemination of Christian doctrine and worldview. It is during this period (roughly 1100-1400) that many of the greatest of the early Icelandic family sagas and histories were composed. These remembrances and reinventions contain much about the pre-Christian past, but it must always be remembered that these sources contribute to the cultural memory of the time in which they were authored rather than the time of the narrative events. ${ }^{29}$ To name just one example, the fourteenth-century short tale from Flateyjarbók entitled Piðranda páttr ok Pórhalls, ${ }^{30}$ which narrates several supernatural competitions between Norse paganism and Christianity during the time of conversion, tells us more reliably about the cultural memory of the fourteenth century than about beliefs or events of the conversion period. ${ }^{31}$ Nevertheless, by viewing these earlier sources as precursors to the post-medieval sources discussed here, a diachronic image of the development of cultural memory in Iceland begins to come into focus. ${ }^{32}$

To complicate matters further, history as we know it today has only been around since the invention of writing or, in societies that accepted the technology of writing much later, since the introduction of that technology to their society. ${ }^{33}$ Oral societies sustained a sense of their collective pasts, presents, and prospects for the future long before the introduction of written histories. In fact, Jan Assmann has posited, contrary to expectations of the modern (literate) world, that oral societies do a better job of preserving cultural remembrances than literate societies. In oral cultures, says Assmann,

28 I will say little about the folkloric elements of this era here, but see Einar Ólafur Sveinsson, The Folk-Stories of Iceland, rev. Einar G. Pétursson and trans. Benedikt Benedikz, ed. Anthony Faulkes, Viking Society for Northern Research, Text Series 16 (London: Viking Society, 2003), especially 71, as well as the work of Merrill Kaplan cited below in footnote 30. For a comprehensive overview of memory studies in Old Norse-Icelandic sources, see Handbook of Pre-Modern Nordic Memory Studies.

29 See, for example, Jesse L. Byock, "Social Memory and the Sagas: The Case of Egils Saga," Scandinavian Studies 76 (2004): 299-316; Jesse L. Byock, Feud in the Icelandic Saga (Berkeley: University of California Press, 1982); Vésteinn Ólason, Dialogue with the Viking Age (Reykjavík: Heimskringla, 1998); and, from a more historiographical perspective, see Sverre Bagge, "The Making of a Missionary King: The Medieval Accounts of Olaf Tryggvason and the Conversion of Norway," Journal of English and Germanic Philology 105 (2006): 473-513.

30 For an in-depth study of folk motifs in Flateyjarbók, perhaps the most important of the medieval Icelandic manuscripts, see Merrill Kaplan's monograph, Thou Fearful Guest: Addressing the Past in Four Tales in Flateyjarbók, FFC 301 (Helsinki: Academia Scientiarum Fennica, 2011).

31 See Merrill Kaplan, "Prefiguration and the Writing of History in Páttr Piðranda ok Pórhalls," Journal of English and Germanic Philology 99 (2000): 379-94.

32 See my discussion of how this comparison works for piðranda páttr in chapter 4, below (109-10 and 113).

33 Walter Ong argues that literacy is "absolutely necessary" for the development of history and other modern studies: Orality and Literacy (New York: Routledge, 2002), 14. 
cultural memory circulates in forms of commemoration that were originally bound up with rituals and festivals. As long as these rites were predominant, the knowledge that was all-important for identity was handed down through repetition. It is the very essence of all rites that they follow a given, unchanging order. Thus each performance is consistent with its predecessors, so that in illiterate societies time typically follows a circular pattern. ${ }^{34}$

In his late twelfth-century Historia de Antiquitate Regum Norwagiensium (An Account of the Ancient History of the Norwegian Kings), Theodoricus monachus (Pórir munkur) calls Icelanders "the people among whom in particular the remembrance of these matters [of the ancient history of Norwegian kings] is believed to thrive ... who preserve them as much celebrated themes in their ancient poems." ${ }^{35}$ The phrase "ancient poems" no doubt refers to Old Norse skaldic verse, ${ }^{36}$ a predominantly oral art form (though many skaldic poems were later venerated in writing) with which Icelanders had considerable facility. Taken together, the comments made here by Theodoricus, and those by Saxo Grammaticus mentioned above, indicate a medieval Icelandic culture that was renowned for its strong sense of its own identity and awareness of its origins, and for its prowess in both written and oral modalities of their cultural memory.

In contrast to oral society, a literate world, according to Assmann, does not produce and sustain cultural memory but rather cultural forgetting, for "as more and more texts sank into the archival background, the written word grew increasingly into a form of forgetting, a graveyard of meanings that had once emerged from live interpretation and communication." ${ }^{37}$ This is in fact one of the challenges of working with nineteenthcentury archival material: archival material, in contrast to the living cultural phenomenon of oral storytelling, may represent more a graveyard of meaning than a living tradition. ${ }^{38}$ However, the relationship between orality and early literacy in Iceland is perhaps a unique one. It is clear that Iceland sustained more of a continuum between orality and literacy in both the medieval and post-medieval periods. Assmann's view may be valid for a fully integrated literacy such as that of our modern western society, ${ }^{39}$ but in a world in the early stages of a transition to literacy, as was the case in Iceland's early history, or a world that is undergoing re-oralization, as is the case in post-medieval

34 Jan Assmann, Cultural Memory and Early Civilization: Writing, Remembrance, and Political Imagination (Cambridge: Cambridge University Press, 2011), 72.

35 Theodoricus monachus, Historia de Antiquitate Regum Norwagiensium-An Account of the Ancient History of the Norwegian Kings, trans. David and Ian McDougall (London: Viking Society for Northern Research, 1998), 41.

36 See Theodoricus, Antiquitate Regum Norwagiensium, xvi-xvii.

37 Assmann, Cultural Memory, 80.

38 For a discussion on how to find variation in archival materials, see Jyrki Pöysä, "Variation in Archived Anecdotes," in Thick Corpus, Organic Variation and Textuality in Oral Tradition, ed. Lauri Honko, Studia Fennica: Folkloristica 7 (Helsinki: Finnish Literature Society, 2000, 577-93, especially 580 .

39 See again Ong, Orality and Literacy, 14. 
Iceland (see below, 17 and 38 for more), the contrast between oral and literate society was much less clearly defined..$^{40}$ Jesse Byock's work on Icelandic cultural memory (though he also uses the phrase "social memory") considers this point from the perspective of the audience. Byock suggests that the Icelandic family sagas, though written and not oral, possess reliable evidence of cultural memory because of their communal nature. ${ }^{41}$ The family sagas were not simply composed by a single person who then inflicted a creative work upon an unsuspecting audience. Even for those sagas that were conceived and penned by a single author, audiences possessed an involved knowledge of both the genealogy and geography referenced in the narratives, which meant the composers of the sagas had to work within the framework of that knowledge. ${ }^{42}$ Aspects of the narratives remain open for revision and creative flourishes, but the parameters enforced by the audience specify which aspects of a narrative are open to modification. ${ }^{43}$ This modification speaks to the malleability of cultural memory mentioned above, yet Byock's point also recognizes that such malleability is not free to be random. Like other cultural memories, Icelandic family sagas must be validated by the community at large. Thus, two components of cultural memory-whether perpetuated by official histories or the folklife of a society, whether written or oralwork together: On the one hand, cultural memory is malleable, subject to change when the culture itself deems it necessary; on the other hand, cultural memory may not be changed at the whim of a single person. The community at large must dictate how the malleability of its own cultural memory ought to proceed through the years. In this way, cultural memory works rather like language: just as the linguistic community determines language, the remembering community determines cultural memory.

This brief overview of cultural memory and its points of contact with the medieval Icelandic world yields four fundamental conclusions about the characteristics of and assumptions about cultural memory to be carried into the following chapters:

40 See for instance, Agnes S. Arnórsdóttir, "Legal Culture and Historical Memory in Medieval and Early Modern Iceland," in Minni and Muninn: Memory in Medieval Nordic Culture, ed. Pernille Hermann, Stephen A. Mitchell, and Agnes S. Arnórsdóttir (Turnhout: Brepols, 2014), 211-30 at 213-15, and Arnved Nedkvitne, The Social Consequences of Literacy in Scandinavia (Turnhout: Brepols, 2004), 72 (as cited by Agnes, 217), where open letters were often read aloud, merging the oral and the literate.

4 I Byock, "Social Memory," 299-316. On "social memory," see footnote 12, above.

42 For more on this view, see Gísli Sigurðsson, The Medieval Icelandic Saga and Oral Tradition: A Discourse on Method (Cambridge, MA: Harvard University Press, 2004), 247-50; and Gísli Sigurðsson, "Njáls saga and Its Listeners' Assumed Knowledge: Applying Notions of Mediality to a Medieval Text," in RE:writing: Medial Perspectives on Textual Culture in the Icelandic Middle Ages, ed. Kate Heslop and Jürg Glauser (Zürich: Chronos: 2018), 285-94.

43 Byock, "Social Memory," 301. 
1. Cultural memory may be manifest in a variety of modalities, be it visual, oral, or literate, and in a variety of genres, be it artistic, literary, historical, or folkloric: Regardless of medium or genre, cultural memory appeals to contexts both internal (as evinced by symbols, images, and topoi) and external (as evinced by appeals to its immediate cultural and historical situation).

2. Cultural memory is malleable, meaning it is not necessarily or fundamentally correspondent with actual events as they happened in history. Since a given memory might or might not coincide with historical events as they occurred in the past, that memory is free to change depending upon the needs of the society.

3. Though malleable, cultural memory also relies upon both internal and external contexts to establish its validity. The interdependence between these two contexts fosters a close relationship between the communicator of the memory (regardless of modality) and the recipients of that memory (the community that sustains the memory). Thus, the malleability of cultural memory is what makes it a worthwhile subject for examination: its disconnect with historical event makes it malleable, but its dependence upon the validation of the culture that sustains it means the cultural memories change as the culture itself changes.

4. In Iceland (and perhaps elsewhere), the production of cultural memories in early literate culture functioned similarly to the way it functioned in oral culture. (And, as will be argued below, that same interplay between literacy and orality continued well into the post-medieval period in Iceland in ways that make it a uniquely valuable location for the exploration of post-medieval cultural memory.)

Cultural memory may not be history, but it is best understood when observable in its historical context. Thus, some understanding (a complete assessment cannot be achieved here) of the Reformation and post-Reformation periods in Iceland will prove valuable to the chapters that follow. The following section offers a brief introduction to these events on both a historical and theological level.

\section{Reformation and Lutheranization: Some Context}

The Reformation in Iceland, like conversion and Christianization in centuries prior, had a profound impact upon the country's developing cultural memory, even though the Icelandic Reformation has received less scholarly coverage than Christianization. Perhaps the greatest difference between the two is that the Icelandic Reformation was a much bloodier affair than the conversion process of $999 / 1000 .^{44}$ With a few important exceptions, the missionary, conversion, and Christianization processes were peaceful in Iceland, ${ }^{45}$

44 See, for instance, Jenny Jochens's oft-cited article on the subject of Iceland's peaceful conversion: "Late and Peaceful: Iceland's Conversion through Arbitration in 1000," Speculum 74 (1999): 621-55.

45 But see Kathleen M. Self, "Remembering Our Violent Conversion: Conflict in the Icelandic Conversion Narrative," Religion 40 (2010): 182-92. 
whereas Reformation, by comparison, all but divided the country. While the concern for the preservation of cultural memory in Iceland carries well into the post-medieval period, a tension between the ecclesiastical elite and the lay person seems even more evident in the later sources than in medieval texts. Possibly, this tension was a reflection of the hostility that accompanied the Reformation. ${ }^{46}$ The reasons behind the violence no doubt require careful consideration, ${ }^{47}$ but it may be sufficient here to attribute a significant portion of the cause to the much stronger presence of an outside government in Iceland than was at play during the lead up to the conversion to Christianity. To be sure, Christianity was largely ushered into Iceland from abroad, but as eager as King Óláfur Tryggvasson of Norway was to see Iceland converted to Christianity, ${ }^{48}$ he never had a ground presence of more than a few representatives (and Iceland never provoked him enough to send more). By the time of the Reformation, however, Iceland had been a dependency of Denmark for a hundred years or so, and the Danish king exerted his authority, either by force or by administration, when he felt the need..$^{49}$ Reformation was no exception.

This foreign presence in Iceland likely prompted a transformation of the fight against Reformation, at least in part, into a fight against foreign domination as well. Jack P. Cunningham suggests that Bishop Jón Arason (1484-1550) of Hólar in the north-the last Catholic bishop in Iceland and the staunchest of opponents to Reformation-fought not just against Reformation but also against the Danish hegemony that had been in

46 There is a greater need for an overview of the events leading to the establishment of Lutheranism in Iceland than for discussion of the details of Christianization, since, in contrast to Christianization, the Reformation in Iceland has been covered much less by scholars, particularly in English. The most thorough treatments of the Reformation in Iceland may be found in Vilborg Auður Ísleifsdóttir, Siðbreytingin á Íslandi 1537-1565 (Reykjavík: Íslenska bókmenntafélag, 1997), and in Loftur Guttormsson, ed., Frá siðaskiptum til Upplýsingar (Reykjavík: Alping, 2000), a comprehensive study of the history of Christianity in Iceland and volume 3 of Hjalti Hugason and Sigurjón Einarson's four-volume Kristni á Íslandi project. In English, a good starting place is Gunnar Karlsson's Iceland's 1100 Years: The History of a Marginal Society (London: Hurst, 2000), 128-48 and 169-72. More recently, Jack P. Cunningham has done two in-depth studies of the events leading up to the Reformation in Iceland. The first, "Jón Arason, 'the last Icelander' and the Coming of the Reformation to Iceland," Reformation and Renaissance Review 11 (2009): 245-73, offers a study of the life of Jón Arason, the last Catholic bishop of Iceland, and the events leading up to his execution in November of 1550. Cunningham's second article on the subject, "Changing Fashions: The Coming of the Reformation to Iceland," Reformation 16 (2011): 65-92, is a broader study of the cultural and political influences that contributed to the Reformation in Iceland. Note that in my subsequent review, much of the basic history of events that took place leading up to Reformation in Iceland is common to all of these sources. My account below of those historical events are, consequently, drawn from these sources essentially simultaneously. For that reason, I offer these sources as a general reference for my following remarks. I will take care, however, to make further reference to specific theses made by respective authors.

47 See Cunningham's articles cited below.

48 For a recent discussion of written sources, especially pertaining to King Óláfur Tryggvason, see Anders Winroth, The Conversion of Scandinavia, 121-37.

49 Cunningham, “Jón Arason," 256-59. 
place since the late fourteenth century. ${ }^{50}$ It is at least true that the violence started at the hands of the Danish. On Whit Sunday 1539, a Danish bailiff-a rather caustic man named Didrich von Minden - and thirteen of his men ransacked the monastery on Viðey, which was taken over by the Danish government thereafter. ${ }^{51}$ The violence set a dark precedent for subsequent confrontations between Lutherans and Catholics. That same year, von Minden went on a similar errand when he and his men stopped at Skálholt to make some trouble, but they seem to have badly miscalculated the strength of Catholic sympathizers. Perhaps von Minden knew that Lutherans were secretly meeting at Skálholt and thus misperceived the situation there, but the Catholic bishop, Ögmundur, was still in charge. Despite their differences, Ögmundur apparently received von Minden and the Danish men hospitably and even warned them that the Catholic contingent in the area might be looking for a fight. ${ }^{52}$ Notwithstanding, von Minden and his men behaved so badly that the Catholic contingent in Skálholt eventually captured and killed the lot of them, von Minden included. The following year, a Lutheran sympathizer, Gissur Einarsson, took over at Skálholt, and in May of 1541 a Danish emissary, Christoffer Huitfeldt, arrived in Iceland with two hundred men to investigate von Minden's death, with Gissur as Huitfeldt's advocate. That same year, Huitfeldt's military force oversaw the Alping's (the Icelandic parliament) ratification of the New Church Ordinance that had been drafted by Christian III in 1536. The ratification was attached in part to the Danish landshjálp (national relief) aimed at relieving Denmark's financial troubles.

Through all of this strife in the south of Iceland, the north remained solidly Catholic, but while all of these developments must have seemed like a nightmare to the much more staunchly Catholic see at Hólar, which was under Jón Arason's authority, the northerners could do little to stop what was happening in the south. Jón Arason seemed to have recognized the futility of fighting off Huitfeldt and his men, either by logic or by force, and did not attend the Alping that year. It is difficult to say what these conflicts looked like in theological terms. Without a doubt, the early Reformers in the south of Iceland shared a conviction to pursue a Lutheran theology, but in the north-and perhaps at any distance-the violence and coercion at the hands of men like von Minden and Huitfeldt must have appeared very much like the hostile actions of a domineering and greedy foreign ruler rather than the manifestation of earnest theological conviction. Regardless, after the ratification of the New Church Ordinance in 1541, Jón Arason and his northern contingent of Catholics arranged a kind of treaty with Gissur and the Reformers in the south. The country would remain thus-divided but peaceful-until the death of Gissur in March of 1548.

50 Iceland had been subject to Norwegian rule from 1262 to 1380 , but family ties ensured that King Ólafur IV (1376-1387) ruled over both Denmark and Norway in 1380 at the death of his father, Hákon VI (1340-1380). At that time Denmark assumed rule over Iceland. After Christian III emerged victorious from the Danish civil war in 1536, he quickly established Lutheranism in his realm. See Gunnar Karlsson, Iceland's 1100 Years, 83-105, for more on these developments.

5 I Gunnar Karlsson, Iceland's 1100 Years, 129.

52 Gunnar Karlsson, Iceland's 1100 Years, 130. 
The three years following Gissur's death would determine the outcome of the conflict between Reformers and Catholics. Jón Arason wasted no time in moving to retake control of the south. He and other priests elected a Catholic bishop, Sigvarður Halldórsson (d. 1550), to reside at the southern see, while the Lutherans elected Marteinn Einarsson (d. 1576), who had strong southern connections. Bishop Jón, two of his sons, and another hundred men then went south to stir up trouble for the southern Lutherans and Jón managed to capture the newly elected Marteinn as well as his chaplain. In the summer of 1550, Bishop Jón challenged Skálholt and, threatening to execute Marteinn, regained control of the southern see at Skálholt; he then restored the monasteries at Viðey and Helgafell. ${ }^{53}$ By all appearances, Bishop Jón had achieved near-total control over the country, and all seemed lost for the Reformers.

The last remaining obstacle for Jón was Marteinn Einarsson's brother-in-law, Daði Guðmundsson, about whom-it must be added incidentally-not enough is written or known by modern scholars. Daði seems almost singlehandedly to have overcome significant military, political, social, and legal challenges to bring about one of the most important events in Icelandic history: the capture and execution of Jón Arason. We may now remember Daði as something of a villain because of his actions and disregard for legal procedure, but the fact remains that he accomplished what seemed an insurmountable task under the circumstances. He had earlier been tasked by the Danish government with arresting Bishop Jón. Until Jón came against him directly, however, Daði had either ignored the Crown's entreaties or had not felt the timing was right. Jón must have felt confident when he went south again in the autumn of 1550 to deal with Daði directly. Despite the odds overwhelmingly in Jón’s favour, Daði nevertheless outmatched him in a series of deft moves, which proceeded as follows: (1) Daði managed to get out of a summons to the Alping, where he was meant to answer to charges against him. (2) When Jón came against Daði in the fall of that year, Jón had with him several dozen of Daði's own neighbours who were ready to act on Jón's, not Daði's, behalf, but Daði managed to convince many of Jón's southern supporters to withdraw their support before the confrontation took place. ${ }^{54}$ Having disbanded much of Jón's force without spilling a drop of blood, it must then have been easy for Daði to overcome his inferior force. (3) When Jón and his sons finally took refuge in a nearby church, Daði disregarded the sanctuary afforded by the sacred place, entered, and captured Jón and his sons. The captives were then held by Marteinn, Daði, and the Danish bailiff, Christian Skriver. Legally, Jón and his sons ought to have been kept alive through the long winter so that they could stand trial at the next Alping, but Daði, Marteinn, and Scriver decided that it would be impossible to do so. (4) Therefore, the three captors-disregarding their legal responsibility, ignoring a decree given by a preliminary jury, and without holding a legal trial-executed Jón and his two sons by beheading. Jón had to watch as his sons were executed: Ari went first, then Björn, and finally Jón. It is said that Jón's beheading took seven strokes.

53 Gunnar Karlsson, Iceland's 1100 Years, 131.

54 Cunningham, “Jón Arason," 266. 
In the following months a contingent from the north came south and hunted down and killed every Danish representative they could find. ${ }^{55}$ This must have felt like a great victory, but the next spring (1551), King Christian III was sufficiently provoked to send two warships and about three hundred men to quell what he viewed as a rebellion. ${ }^{56}$ Afterwards, Daði was absolved of any wrongdoing by the lawman Ormur Sturluson, who judged that Jón and his sons had been handled appropriately. Daði also received a letter from Marteinn Einarsson exonerating him and the others in his party. It may be, as Jack P. Cunningham suggests, that "Daði found the stain of guilt a difficult one to remove as he sought religious, as well as, legal absolution." ${ }^{57}$ Regardless of how his feelings of guilt factored into things, Daði's pursuit of both religious and legal exoneration must have served him well in the eyes of his neighbours, but the cultural memory of a holy Catholic church persisted in Iceland for some considerable time. In the following spring, Jón's surviving son Sigurður and daughter Pórunn received permission from Bishop Marteinn to come south to take Jón's remains to the north. It is said that all manner of miracles followed Jón's final journey back to Hólar.

\section{Lutheranization and Icelandic Folk Stories}

After the struggle over Reformation was won by Reformers in Iceland, the real work of religious change began. Just as we must not focus too much on a specific date of conversion to Christianity, the Reformation of the church in Iceland must be viewed as a longer process than just the proclamation of Lutheranism throughout the country. Re-education was required, and despite the fact that the theological changes implemented after the Reformation had less potency than some of the stauncher reformers would have liked ${ }^{58}$ early Lutheran leaders in Iceland had their work cut out for them. The bulk of the re-education effort fell to Guðbrandur Porláksson, the bishop of Hólar from 1571 till his death in 1627. Guðbrandur, however, faced an entirely different sort of problem from the early Icelandic converts to Christianity. Two aspects of culture threatened the Lutheran church: the remains of Catholic teaching, on the one hand, and a persistent heterodoxy associated with Iceland's ancient past on the other. The primary medium of the latter consisted of stories, songs, and poems passed from person to person and from farmstead to farmstead. Guðbrandur in fact composed his Sálmabók (Book of Hymns) for the express purpose of competing with the vast numbers of these tales, ballads, and songs that he perceived as heterodox. In his introduction to Sálmabók, he states his desire that

men might be able to put away unprofitable songs of trolls and of the [pagan] peoples of old [Trölla og Fornmanna] ... such as are loved and practiced by the common folk [Alpydu Folke], to the displeasure of God and his angels, and to the delight and service of the Devil

55 Gunnar Karlsson, Iceland's 1100 Years, 133.

56 Gunnar Karlsson, Iceland's 1100 Years, 133.

57 Cunningham, "Changing Fashions," 67.

58 Cunningham, "Changing Fashions," 67. 
and his messengers, such as is not seen in any other Christian land and more like the manner of Heathen men than Christian. ${ }^{59}$

But who were these "albýða fólk," and how far back does their cultural memory go? Far enough, it seems, to concern the most influential church leader of the day.

At this time, Lutheranism had only just been established in Iceland, and Guðbrandur was busy educating Icelanders on the new way of doing things. He might have even felt that this contrary folk culture in Iceland was partly due to a lax treatment of heterodoxy by his Catholic predecessors. In areas of morality, certainly, the new Lutheran leadership stiffened against what was seen as immoral activities in Iceland. The Stóridómur, or Great Verdict, was a series of laws enacted in Iceland in 1564 meant to stamp out unacceptable behaviour that had been more or less tolerated under Catholicism. But that was a question of morality. Against competing narratives, Guðbrandur, at least, seems to have fought fire with fire, or rather verse with verse. In addition to his Sálmabók, he wrote a collection of religious verses, published in 1612, called Vísnabók Guðbrands, ${ }^{60}$ or Guðbrandur's Book of Verses, in which he attempted to redirect popular interest away from offensive secular literature and toward verses more acceptable to God.

It seems not to have worked. For the next two hundred years, subsequent religious leaders echoed Guðbrandur's grievances against secular literature. ${ }^{61}$ Priests resorted to calling upon the heads of households to prevent members of the house from indulging in suspect storytelling, but to no apparent avail. At that time, after the Reformation and long after conversion, there persisted a cultural space in which narratives of heterodox beliefs found a comfortable home. Though not alternatives to Christian religion, these narratives were seen by some as a real and perceptible threat to the laity. Church leaders fought against them, sometimes with alternative literary creation, sometimes with rhetoric, and on very rare occasions with violence. Efforts to overcome the appeal of

59 This quotation from En nij Psalmabok is most accessible in Driscoll 14. See, however, En nij Psalmabok at http://baekur.is/is/bok/000603210/0/23/Ein_ny_Psalma_Bok__Bls_23. My translation, like Driscoll's (in The Unwashed Children of Eve), is based on Guðbrandur Vigfússon and F. York Powell, Corpvs Poeticvm Boreale: The Poetry of the Old Northern Tongue, from the Earliest Times to the Thirteenth Century (Oxford: Clarendon, 1883), 2:388, although note several small changes I have made to bring the translation closer to the original, if less agreeable aesthetically. See also Shaun F. D. Hughes's translation in "The Last Frontier: The Renaissance in Iceland, 1550-1750," Parergon: Bulletin of the Australian and New Zealand Association for Mediaeval and Renaissance Studies 12 (1975): 20-31.

60 In 1612, this work had the title Ein ný vísnabók með mörgum andlegum vísum og kvæðum, sálmum, lofsöngvum og rímum úr heilgagri ritningu almúga fólki til gagns og góða prentuð og peim öðrum sem slíkar vísur elska vilja og iðka Guði almáttugum til lofs og dýrðar en sér og öðrum til gagns og skemmtunar (A new book of verses with many sacred verses and poems, psalms, hymns, and rímur from holy scriptures for the use of common folk and printed so that they can use it as they wish and pursue almighty God to his praise and glory and other uses and enjoyment).

6I For an overview of these efforts see Matthew James Driscoll, The Unwashed Children of Eve: The Production, Dissemination and Reception of Popular Literature in Post-Reformation Iceland (Enfield Lock: Hisarlik, 1996), 13-16. 
those narratives of heterodox belief seem to have produced more of an admixture than a total rejection of them, as post-medieval ${ }^{62}$ Icelanders continued to show an awareness of literary and historical cultural identity that intertwined their diverse beliefs. The seventeenth century saw the production of a stock of reproductions of Old Norse sagas, many of which had not survived from the medieval period. ${ }^{63}$ Added to this literary production (or re-production), ample evidence suggests that post-medieval Iceland also experienced a lively oral transmission of remembrances of the past in the form of rímur. ${ }^{64}$ These rímur and the Old Norse-Icelandic sagas were mainstays at the kvöldvaka, literally "night-wake," a nightly (especially during the cold winter months) gathering in households in which songs, sagas, rímur, and religious writings were read or sung to pass the time. All of this amounted to a kind of "re-oralization" process by which stories from the medieval period re-entered the Icelandic cultural memory (if they had ever left) in the post-medieval period. ${ }^{65}$ Thus, the vibrant cultural memory that originated in the early medieval period carried over into the post-medieval period, despite the major changes in religion and government.

During the nineteenth century, Icelandic intellectuals grew intrigued by the work being done by the Grimm brothers and others and began collecting and cataloguing folk narratives from around Iceland. There was no shortage of contributions from all over the country. Due in large part to its lively storytelling traditions, Iceland was well placed to compile one of the great collections of folklore in the nineteenth century. Icelanders Jón Árnason and Magnús Grímsson, admiring the work of Jacob Grimm, set out to produce their own collection of Icelandic folktales. The first work to come from their efforts was Íslensk æfintýri (Icelandic Adventure Tales), published in 1852. After its publication, financial concerns hampered their collection of tales until the German scholar Konrad Maurer visited Iceland and revitalized the project. When Magnús Grímsson's health began to fail, Jón Árnason continued collecting sources, sending requests throughout the country. ${ }^{66}$ The voluminous collection of folk narratives that

62 The label "early modern" does not quite apply in the case of Iceland. I take the term "postmedieval Iceland" to refer to the period from about 1500 to about 1900, that is, leading up to and following the Reformation (ca. 1548-1575).

63 See Margrét Eggertsdóttir, "From Reformation to Enlightenment," in A History of Icelandic Literature, ed. Daisy Neijmann, Histories of Scandinavian Literature 5 (Lincoln: University of Nebraska Press, 2006), 174-250; Driscoll, Unwashed Children, 1-33.

64 See Shaun F. D. Hughes, "Report on Rímur," Journal of English and Germanic Philology 79 (1980): 477-98, for a cornerstone study of rímur, along with Shaun F. D. Hughes, "Rímur," in Dictionary of the Middle Ages, ed. Joseph R. Strayer, 13 vols. (New York: Scribner, 1987), 10:401-7.

65 Lena Rohrbach refers readers to Jürg Glauser, "Tendenzen der Vermündlichung isländischer Sagastoffe," in (Re)Oralisierung, ed. Hildegard L. C. Tristram (Tübingen: Narr, 1996), 111-25, as the first iteration of this notion. See Rohrbach, "Drama and Performativity," in The Routledge Research Companion to the Medieval Icelandic Sagas, ed. Ármann Jakobsson and Sverrir Jakobsson (Abingdon: Routledge, 2017), 144).

66 Jón Árnason, Hugvekja til alpýðlegra fornfræða [Reykjavík: n.p., 1987]. First published in Íslendingur, vol. 2.12 (October 19, 1861), 91-93. 
grew out of these efforts cultivated all manner of images and genres-mythological, legendary, and historical-including stories of contemporary events, of stories purportedly from the ancient past, and from every era between. The final product was called Íslenzkar pjóðsögur og æfintýri (Icelandic Folk/National Stories and Adventure Tales). ${ }^{67}$ In the words of Einar Ólafur Sveinsson, "the vast majority of the best and most important stories in every field of Icelandic folklore were included in it." ${ }^{\prime 68}$ Whether memories (however inaccurate) of ancestral paganism or stories of mythical events (however fanciful), many of these collected tales reflect something of those heterodox belief narratives that so displeased Guðbrandur Porláksson in the late sixteenth and early seventeenth centuries.

Odd though it may seem given Guðbrandur's harsh words against "unprofitable songs," Icelandic churchmen made significant contributions to the collection. By this time the Enlightenment had reached Iceland, and church leaders turned their concern more toward philosophical worldviews than folklore narratives, which seem to have been relegated to a kind of anthropological curiosity. In a thorough study of the role of Icelandic clerics as collectors and reporters of nineteenth-century Icelandic folklore, ${ }^{69}$ Terry Gunnell observes that clerics, perhaps contrary to their calling to uphold orthodoxy and shun superstition, made a significant contribution to the collection and codification of folklore in Iceland as early as the sixteenth century, and that during the mid-nineteenth-century initiatives of Jón Árnason, certain clerics were on the front lines of the collection and reporting of tales. Gunnell points out that amongst Icelandic clerics, opinions toward the folk traditions varied. Some seemed to have no interest at all $;^{70}$ others were, as one might expect, dubious of the spiritual quality of the tales; ${ }^{71}$ still others came to recognize the nationalistic value of these tales. ${ }^{72}$ These various opinions notwithstanding, argues Gunnell,

there was clearly very little real antagonism to the beliefs involved ... The main question seems to have been one of literary value, and this material was far from as threatening to the establishment as other works that were beginning to appear around this time: Folk tales were not Nietzsche's Zarathustra, Ibsen's Ghosts, Wilde's The Picture of Dorian Grey [sic], or Hardy's Tess of the D'Urbervilles." ${ }^{73}$

67 In the present book, I will refer to the six-volume, 1954-61 edition of this collection, which includes many of the tales Jón Árnason elected to leave out of his first publication: Jón Árnason, Íslenzkar pjóðsögur og ævintýri, ed. Árni Böðvarsson and Bjarni Vilhjálmsson, 6 vols. (Reykjavík: Pjóðsaga, 1954-61).

68 Einar Ólafur Sveinsson, Folk-Stories of Iceland, 139.

69 Terry Gunnell, "Clerics as Collectors of Folklore in Nineteenth-Century Iceland," ARV: Nordic Yearbook of Folklore 68 (2012): 45-66.

70 Gunnell, "Clerics as Collectors," 50-51.

7I Gunnell, "Clerics as Collectors," 56.

72 Gunnell, "Clerics as Collectors," 59.

73 Gunnell, "Clerics as Collectors," 56-57. 
If this is the case, then it reduces the likelihood that those clerics who collected tales for Jón Árnason would have intentionally altered them to exclude or minimize heterodox beliefs.

This deduction, if valid, must not imply that the assessment of post-medieval Icelandic folk narrative is unproblematic. Gunnell has highlighted the importance of the morpheme bjóð- ("nation" or "the people") in the editing and collection of Jón Árnason. ${ }^{74}$ By contrast, Einar Ólafur Sveinsson, in his 1939 publication on Icelandic folklore, Um Íslenzkar pjóðsögur, often used the morpheme alpýða-, more expressly connoting the "common people," rather than pjóð-, meaning "national," to refer to "folk" belief. Perhaps the most significant of the difficulties inherent in examining the late Icelandic material for cultural memory is that of sorting out whether there is a difference between a distinctly nationalistic folklore and folk belief on a local level. Understanding the cultural memory of a given society at a given time requires an awareness of both internal and external contexts. For literary sources, that means having knowledge of manuscript origins and source transmission. For folkloristic sources, this awareness means having reliable information about editorial and collection practices. ${ }^{75}$ We must acknowledge any evident agendas that saga writers, collectors, and editors might have had pertaining to the source at hand. It should be clear that the most essential elements of a successful study of folklore as a site for cultural memory are the external and internal contexts for respective sources. ${ }^{76}$

Each of the five anchor stories for the following chapters- "Djákninn á Myrká" (The Deacon of Myrká), ${ }^{77}$ "Álfkonan hjá Ullarvötnum" (The Elf Woman at Ullarvötn), ${ }^{78}$

74 Terry Gunnell, "Daisies Rise to Become Oaks: The Politics of Early Folktale Collection in Northern Europe," Folklore 121 (2010): 23-24.

75 See Júlíana Póra Magnúsdóttir, "Gender, Legend, and the Icelandic Countryside in the Long Nineteenth Century: Re-Engaging the Archives as a Means of Giving Voice to the Women of the Past," Folklore 129 (2018): 129-47, for a thorough discussion of the value of nineteenth-century Icelandic sources.

76 For key examples of this discussion see Richard Bauman, "Differential Identity and the Social Base of Folklore," in Toward New Perspectives in Folklore, ed. Américo Paredes and Richard Bauman, Publications of the American Folklore Society, Bibliographical and Special Series 23 (Austin: University of Texas Press, 1972), 31-41; Richard Bauman, Story, Performance and Event: Contextual Studies of Oral Narrative (Cambridge: Cambridge University Press, 1986); Anna-Leena Siikala, Interpreting Oral Narrative, FF Communications 245 (Helsinki: Suomalainen Tiedeakatemia, 1990); John D. Niles, Homo Narrans: The Poetics and Anthropology of Oral Literature (Philadelphia: University of Pennsylvania Press, 1999); Richard Bauman and Donald Braid, "The Ethnography of Performance in the Study of Oral Traditions," in Teaching Oral Traditions, ed. John Miles Foley (New York: Modern Language Association, 1998), 106-22; Lauri Honko, "Thick Corpus and Organic Variation: An Introduction," in Thick Corpus, Organic Variation and Textuality in Oral Tradition, ed. Lauri Honko, Studia Fennica Folkloristica 7 (Helsinki: Finnish Literature Society, 2000), 3-28; John Miles Foley, How to Read an Oral Poem (Urbana: University of Illinois Press, 2002).

77 Jón Árnason, Íslenzkar pjóðsögur og ævintýri, 1:270-72. Hereafter, this will be referred to as JÁ followed by volume and page number.

78 JÁ 1:97-99, from the manuscripts of Ólafur Sveinsson of Purkey (1762-1845). 
"Sels-Móri eða Porgarður" (Porgarður, the Móri of Sel), ${ }^{79}$ "Tungustapi” (The Elf Church at Tungustapi), ${ }^{80}$ and "Tornæmi drengurinn og kölski" (The Stupid Boy and the Devil) ${ }^{81}$-allow for an understanding of their respective internal and external contexts. When such contexts are discernable, it becomes possible to view such narratives as "doorways" to cultural meaning. As Gunnell says, "these narrative 'doorways', however they were collected, have the potential to say something about background context and the wider living space that gave birth to them, spaces that should never be forgotten as scholars examine the structural symmetry of the door frames and the quaintness of the door handles." ${ }^{\prime 2}$ Due to the importance of connecting source material to a specific cultural context, an approach focused on a distinct community works better than a broad, international, comparative assessment. Iceland provides fertile ground for literary and folkloristic studies alike. On this point, Bo Almqvist argued that Icelandic folk materials are especially valuable to folklorists, citing, among other reasons, the "scope and quality of the source material, old and new, and the extent to which legends survived until recently." ${ }^{83}$ Almqvist also argued that the geographic and cultural conditions in Iceland readily lend themselves to a clearer picture of the nature, history, and function of the country's folklore materials.

\section{Final Thoughts}

Each of the following chapters begins with a retelling (or translation, if the story has never before appeared in English) of one important, sometimes under-appreciated folk story from Jón Árnason's nineteenth-century collection of Icelandic folktales: "The Deacon of Myrká" relates the story of a young man who tragically dies only to return after death to haunt his beloved. The story has deep roots in international folklore and indicates much about the development of conceptions of death throughout the history of Iceland and greater Scandinavia. "The Elf Woman at Ullarvötn" describes the odd events that lead to a human man becoming the lover of an elf woman, who-most uncharacteristically-is liberated of her elf-hood to become Christian. "Porgarður, the Móri of Sel" offers the account of a fylgja (a kind of attendant spirit) who threatens to terrorize a family for nine generations. The story finds its origins in Norse paganism,

79 JÁ 1:373-76, collected from Jón Porleifsson (1825-1860).

80 JÁ 1:32-35, compiled by Jón Árnason from stories circulated in Álftanes, Seltjarnarnes, and elsewhere in the region of Árnessýsla (in the southwest of Iceland). Valgerður Jónsdóttir (1771-1856) and Hólmfríður Porvaldsdóttir (1812-1876) are also listed as sources.

8 I JÁ 1:483-84, collected from Markús Gíslason (1837-1890).

82 Terry Gunnell, "Narratives, Space, and Drama: Essential Spatial Aspects Involved in the Performance and Reception of Oral Narrative," Folklore (Tartu) 33 (2006): 12.

83 Bo Almqvist, "Midwife to the Fairies (ML 5070) in Icelandic Tradition," in Legends and Landscape: Articles Based on Plenary Papers from the 5th Celtic-Nordic-Baltic Folklore Symposium, Reykjavík, 2005, ed. Terry Gunnell (Reykjavík: University of Iceland Press, 2008), 274. 
though the twists and turns that bring it to its post-medieval form indicate quite a lot about the development of supernatural attendants and companionship. "The Elf Church at Tungustapi" relates the story of a contest between a Christian church and an elf church hidden away in the rocky crag known as Tungustapi. This story says much about the importance of sacred and forbidden spaces in the history of religion in Iceland and beyond. Finally, "The Stupid Boy and the Devil" offers a classic account of a young boy who unwittingly makes a deal with the Devil, and how he escapes damnation in the end. This story has ties to possibly the oldest folklore tale type in the Indo-European world, and it helps illuminates the great and often mysterious Icelandic magicians' tales.

Many other folk narratives, Old Norse-Icelandic sagas, and histories will be woven into the accounts of these five stories along the way. Ultimately, these tales function especially well as "doorways" to a greater legacy of storytelling and cultural memory in Iceland and beyond. Building upon Terry Gunnell's notion, the present study argues that these narratives work not only as doorways through which we, in the present, might look to perceive cultural memories of the past. They also serve as mechanisms by which living cultural memories of belief were established and fostered during the periods when these stories were told. A basic need for a rational system of beliefs ${ }^{84}$ drives the cultivation of such a mechanism, and tracing the origins and developments of these stories gives us the opportunity to understand something about the transformation of cultural memories of religious belief in the North. As Richard Firth Green observes, vernacular culture "might make remarkable efforts to adjust its beliefs to the orthodoxies of the church." ${ }^{85}$ These efforts may be evident in Icelandic cultural memory as well, but the manner in which such efforts occur and the mechanisms by which those adjustments are made point us to a telling conclusion: while the Church might not endorse folk stories about elves, trolls, and witches, the folk stories themselves suggest a basic desire to be reconciled-if not always with the leadership of the Church, then with the fundamental beliefs represented by the Church.

84 My understanding of a "system of beliefs" follows conceptually from those of Mihály Hoppál's "Linguistic and Mental Models for Hungarian Folk Beliefs," in Myth and Mentality: Studies in Folklore and Popular Thought (Helsinki: Finnish Literature Society, 2002), 50-66, and Robert A. Hahn, "Understanding Beliefs: An Essay on the Methodology of the Description and Analysis of Belief Systems," Current Anthropology 14 (1973), 207-24. I stop short of arguing for an individual's or group's beliefs in a certain system, since these are psychological in nature and cannot be discerned from the present type of study. I do, however, share Hoppál's essential view that systems of belief, whether superstitious, orthodox, or juvenile, follow a discernable (though perhaps not always rational) logic. Logic of this kind can be identified within narratives, if not within individual beliefs. See especially Hoppál's overview of systems of belief in "Linguistic and Mental Models," 52-57. As Richard Firth Green has recently argued, "when belief in fairies could offer a reasonable explanation for many things that would otherwise have seemed inexplicable, rationality, in this sense, must be viewed as every bit as historically contingent as belief" (Elf Queens, 70).

85 Green, Elf Queens, 2. Green here evokes the idea first posited by Carlo Ginzburg of "cultural compromise formation." See Ginzburg, Ecstasies: Deciphering the Witches' Sabbath, trans. Raymond Rosenthal (New York: New York University Press, 2000), 11. 



\section{Chapter I}

\section{THE DEAD BRIDEGROOM CARRIES OFF HIS BRIDE: PEJORATION AND ADJACENCY PAIRS IN ATU 365*}

\section{“Djákninn á Myrká” (The Deacon of Myrká)'}

In the north of Iceland, there once lived a church deacon at a farm called Myrká [Dark Water]. His name is not recorded, but he was in love with a beautiful young woman named Guðrún, who lived at the nearby farm at Bægisá on the opposite side of the river Hörgá from Myrká. The deacon would often ride his trusted horse, Faxi, to visit Guðrún. A little before Christmas one year he rode there to ask whether she would like to go with him to the Christmas Eve party at Myrká. She happily agreed, and the deacon returned to Myrká, promising to come back on Christmas Eve to escort Guðrún to the party. About that time there had been an unusual thaw along the river Hörgá, so when he tried to cross on his way back to Myrká that night, the ice broke up to make his usual fording impossible. The deacon rode down the river and tried to cross closer to Saurbæ, the farm below Myrká, but his horse stumbled on the ice and threw its rider. The deacon fell and suffered a gruesome, fatal wound on the back of his head. The next morning a neighbouring farmer woke to find Faxi, the deacon's horse, saddled and grazing in his field, but the deacon was nowhere to be found. The farmer went out to search for him, fearing the worst, and he found the deacon's body near the river. Shortly thereafter the deacon was buried in the Myrká churchyard, but because of the changing weather conditions, word of the tragedy did not to reach Guðrún across the river, which is why on Christmas Eve, she was not surprised to see the deacon arrive at Bægisá as planned to escort her to the party. The deacon was a little quiet, a little pale, and strangely cold, but she mounted the horse behind him and they began the trip to Myrká. As they crossed the Hörgá, the deacon's hat slipped forward just enough to reveal the nasty, clearly fatal wound on the back of his head. The deacon then recited an ancient poem:

\footnotetext{
* An early version of this chapter was published as "The Moon Glides, Death Rides: Pejoration and Aborted Otherworldly Journeys in 'The Dead Bridegroom Carries Off His Bride' (ATU 365)," Intégrité 16 (2017): 13-30.

I Adapted from "Djákninn á Myrká" (JÁ 1:270-72). It could be objected that the informant for "Djákninn á Myrká," a housewife named Ingibjörg Porvaldsdóttir (1807-1873), lived, as far as we know, in Belgsholt in Borgarfjörður (in the west of Iceland) and had no real connections with the Myrká farm or Hörgardalur (JÁ 1:678, note for "270. Djákninn á Myrká"). However, a variant of the tale recorded by Páll Jónsson (1812-1889), of Valla, who worked at Myrká in Hörgardalur, corroborates the story, saying that he had seen the stone under which the deacon was said to have been buried and that a woman there had told him the story (JÁ 1:272).
} 


\author{
Máninn líður, \\ dauðinn ríður; \\ sérðu ekki hvítan blett \\ í hnakka mínum,
}

Garún, Garún?

\author{
The moon glides, \\ death rides; \\ don't you see the white gash \\ in my neck, \\ Garún, Garún?
}

Guðrún was terrified but brave. She stayed on the horse behind the deacon until they arrived at Myrká, when she realized that the deacon was taking her to the churchyard where his open grave awaited them both. At this, Guðrún's fear seized her and she fought to get away. Looking desperately for any way to free herself, Guðrún scrambled and grabbed at whatever was close at hand, and as they crossed the threshold of the graveyard, she managed to get hold of the bell cord at the gate leading into the churchyard and rang the bell for her very life. The sound of the bell was enough to send the deacon into a frenzy. Guðrún escaped, but in his frenzy the deacon was able to clutch her riding cloak, and with it still in his hand he went down into his grave as the dirt poured in over him.

Thus begins ${ }^{2}$ the story of "The Deacon of Myrká," one of the great specimens of nineteenth-century Icelandic folktales collected by Jón Árnason. Hidden beneath the haunting visual images of the deacon riding his horse, Faxi, in the moonlight as Guðrún sits terrified behind him is a history of the love between the couple and the tragedy of Guðrún's loss. The tale is also deeply connected to the geography of Iceland. The river Hörgá runs in the north, not far from the now-popular tourist town of Akureyri, where the farms of Myrká, Bægisá, and Saurbæ are situated just as they ought to be according to the tale. Myrká is a small farm now, about ten kilometers from Bægisá. Just on the Bægisá side of the river, a great slope rises to divide the two, so that Myrká sits in a kind of valley through which the Hörgá flows. The interested tourist (or folklorist) can easily follow the deacon's tracks from Myrká to Bægisá and back, noting on the way different places where he might have forded the Hörgá, and where he might have died. It is obvious to anyone who walks those paths why the deacon elects to go downriver to Saurbæ-instead of upriver toward Myrká-to find a better place to ford: the river's banks become far too craggy to cross closer to Myrká.

The story also has deep roots in the Scandinavian beginnings of Iceland, reaching, as we shall soon see, far back into Old Norse and even Proto-Indo-European origins. For all of the intrigue of the story-its geographic connections, its ancient origins, and its lasting value as a classic horror story-one subtle but vital question lingers just below the surface: as tragic as the story is, it offers no explanation for why the deacon, who by all accounts was a good man in life (a deacon in the local church, seemingly well respected in the region, and well-liked by Guðrún), transforms into such an evil creature after his

2 The story goes on to tell of the deacon's continued haunting of Guðrún, until a powerful galdramaður (sorcerer) came to Myrká and put his ghost to rest by placing a boulder over his grave. This ending will be considered in more detail below (30-31). 
death that he would want to haunt and murder the one person he seems to love most. Discovering an answer to this question requires an exploration of the cultural memory embedded in the narrative, which leads to a study of how the story was constructed over a long period of time, reaching as far back as the mythology and religion of the medieval North, and the cultural and religious influences upon the Icelandic society that produced the "The Deacon of Myrká."

\section{ATU 365 and Connections to Old Norse Literature}

Indications of the earliest manifestations of this story may be found by recognizing "The Deacon of Myrká" as a classic example of the international tale type known as "The Dead Bridegroom Carries Off His Bride" (ATU 365), ${ }^{3}$ which has at its core the story of a recently deceased bridegroom who returns from the dead to take his unwitting bride into the grave with him. This tale type has enjoyed a remarkably broad appeal among storytellers throughout Europe. Hans-Jörg Uther identifies examples of it in no less that forty-five distinct cultures, all but one of which (Japanese) have their origins in either the European (in forty instances) or the Finno-Ugarit world (in four instances). ${ }^{4}$ Francis Child was the first to recognize a connection between ATU 365 and Old Norse narrative. In his late nineteenth-century collection, English and Scottish Popular Ballads, Child says of the eighteenth-century ballad "Sweet William's Ghost," that it "agrees in many particulars with the conclusion of the second lay of Helgi Hundingsbani in the Elder Edda." 5 Since Child's remarks, numerous passing references to a connection between Old Norse sources and ATU 365 may be found throughout scholarly discussions, yet there has been no in-depth examination of those possible connections. To do so would require a more involved study than is possible here, but I hope at least to set the foundations for future work.

Three important medieval connections to ATU 365 bear relevance to the "Deacon of Myrká." First, the Eddic poem "Helgakviða Hundingsbana Önnur" (The Second Lay of Helgi Hunding's Bane) presents the final chapter of two heroic lovers-the great king Helgi and his Valkyrie wife, Sigrún-whose love had endured great adversity only for Helgi to be killed at the hands of Sigrún's brother, Dagr. A burial mound is raised for

3 Though there are at least five recorded variants of ATU 365 in Iceland, I will focus on "The Deacon of Myrká" because it is the most complete and most elegant. As Jacqueline Simpson notes (Icelandic Folktales \& Legends (Stroud: Tempus, 2004), 150), these variants may be found in JÁ 1:272-3 and 273-74. See also Konrad Maurer, Isländische Volkssagen der Gegenwart (Leipzig: Hinrich, 1860), 73; and Einar Ólafur Sveinsson, Verzeichnis Isländischer Märchen-varianten, FFC 83 (Helsinki: Academia Scientiarum Fennica, 1929), 33; but see my comments below (43-44) on these variants.

4 Hans-Jörg Uther, The Types of International Folktales: A Classification and Bibliography, Based on the System of Antti Aarne and Stith Thompson, 3 vols. (Helsinki: Suomalainen Tiedeakatemia, Academia Scientiarum Fennica, 2004), 1:229-30. Hereafter these tale type designations will be referred to by their abbreviated name and ATU number, in this case: "The Dead Bridegroom," ATU 365.

5 Francis Child, English and Scottish Popular Ballads, ed. Helen Child Sargent and George Lyman Kittredge, 5 vols. (Toronto: University of Toronto Press, 1882-98), ballad no. 77 (3:226-34). 
Helgi, and he is said to go on to Óðinn's hall to join the einherjar, that prestigious group of warriors who will fight for Óðinn at the end of the world. Sigrún's grief and tears are so great, however, that she calls him back to the living for one last night with his bride. The relevant passages read as follows:

Heim gekk ambótt ok sagði Sigrúnu:

42. "Út gakk pú, Sigrún

frá Sevafjollum,

ef pik fólks jaðar

finna lystir.

Upp er haugr lokinn,

kominn er Helgi;

dólgspor dreyra,

dǫglingr bað pik

at bú sárdropa

svefja skyldir."

44. "Fyrr vil ek kyssa

konung ólifðan

en pú blóðugri

brynju kastir.

Hár er pitt, Helgi,

hélu prungit,

allr er vísi

valdoggg sleginn,

hendr úrsvalar

Hǫgna mági.

Hvé skal ek pér, buðlungr,

pess bót of vinna?"

[Sigrún bjó sæing í hauginum.]

47. "Hér hefi ek pér, Helgi,

hvílu gǫrva,

angrlausa mjǫ,

Ylfinga niðr;

vil ek pér í faðmi,

fylkir, sofna,
The handmaid went home and said to Sigrún:

42. “Go out, Sigrún

from Sevafjall,

if you want to

find the leader of the troop.

The barrow has opened,

Helgi has come;

gaping wounds bleed,

the king requested

that you soothe

his bloody injuries."

44. "First I will kiss

the lifeless king

before you cast off

your bloody mail.

Your hair, Helgi,

is covered with hoar-frost,

The prince is all

wet with the dew of the corpse,

the hands of

Hǫgni's son-in-law are cold and wet.

How shall I, lord,

bring about a cure for this?"

[Sigrún made a bed in the barrow.]

47. "Here, Helgi, I have

made a resting place,

free from heavy cares,

descendant of Ylfings;

in your embrace I will

sleep, Lord, 
sem ek lofðungi

lifnum myndak."6 as I would with

the prince when he was alive."

Like "The Deacon of Myrká," this narrative poem tells of a woman who survives the man she loves. The relevant elements are that (1) a well-respected man, Helgi, has died and he bids his beloved, Sigrún, to enter his burial mound with him to tend his bloody wounds; (2) Sigrún, grieving, willingly and eagerly does so and ornately prepares a bed for them both to lie upon; and, most importantly, (3) in the morning, Helgi returns to Valhalla and does not come back. Sigrún dies of grief not long after.

Closely related to the death scene in "Helgakviða Hundingsbana Önnur" is another Eddic poem, "Sigurðarkviða in Skamma" (The Short Lay of Sigurður), which is a version of possibly the most famous story in all of Germanic and Old Norse literature-that of Sigurður Fáfnisbani and the Valkyrie, Brynhildur:

65. “Biðja mun ek pik
bœnar einnar,
sú mun í heimi
hinzt bœn vera:
Láttu svá breiða
borg á velli
at undir oss ǫllum
jafnrúmt sé,
peim er sultu
með Sigurði.

66. “Tjaldi par um pá borg

tjoldum ok skjǫldum,

valarift vel fáð

ok Vala mengi;

brenni mér inn húnska

á hlið aðra.

67. “Brenni inum húnska

$$
\begin{aligned}
& \text { á hlið aðra } \\
& \text { mína bjóna } \\
& \text { menjum gofga"7 ... }
\end{aligned}
$$

65. "I must make

one request of you,

it will be my last

request in this world:

Let a pyre be prepared

In the meadow

with enough space

for all of us-

those who die

with Sigurður.

66. "Cover the pyre with

tapestries and shields,

foreign cloths, well-made

and a host of foreign slaves;

the southerner should burn

beside me.

67. "On the other side

of the southerner should burn

my serving women,

wearing splendid jewels" ...

6 Eddukvæði, ed. Jónas Kristjánsson and Vésteinn Ólason, Íslenzk Fornrit, 2 vols. (Reykjavík: Hið Íslenzka Fornritafélag, 2014), 2:280-81.

7 Eddukvæði 2:347-48. 
This poem describes Brynhildur's lamentations after the great hero, Sigurður, meets his unfortunate demise (even though Brynhildur is the one who arranges his murder). This burial scene again features (1) the death of a well-respected man, (2) the grieving bride who goes to her lover and prepares a marriage bed/pyre upon which the lovers lie, (3) which will facilitate the journey into the afterlife. To point (3), Brynhildur proclaims, "Shut not yet on Sigurður's heels / the gleaming, ring-locked gates of Hel" (st. 69), implying that Sigurður cannot, or must not, make the otherworldly journey into the afterlife without his bride.

A third medieval reference is more controversial. It has become unpopular to associate these two death and burial scenes from the Poetic Edda with the wellknown tenth-century account of a (possibly Scandinavian) ship burial on the Volga River described by the Muslim traveller Aḥmad ibn Faḍlān, mainly, I suppose, because it remains uncertain that ibn Faḍlān was indeed describing a tribe of Scandinavian voyagers who had come so far into Russia. ${ }^{8}$ If the rituals described are not Scandinavian, then it is difficult to see how they would be connected to burials described in Scandinavian Eddic poetry. ${ }^{9}$ Regardless of these reservations, the similarities between the Eddic death scenes and the burial ritual described by ibn Faḍlān are, frankly, quite strong. According to his account,

They produced a couch and placed it on the boat, covering it with quilts and cushions made of Byzantine silk brocade. An aged woman whom they called the Angel of Death turned up. She spread the coverings on the couch. It is her responsibility to sew the chieftain's garments and have him prepared properly, and it is she who kills the female slaves. $^{10}$

And later:

Six men entered the yurt. They all had intercourse with the female slave and then laid her beside her master. Two held her feet, two her hands. The crone called the Angel of Death placed a rope around her neck with the ends crossing one another and handed it to two of the men to pull on. She advanced with a broad-bladed dagger and began to thrust it in and out between her ribs, now here, now there, while the two men strangled her with the rope until she died. ${ }^{11}$

Here we may observe that, despite the brutality, several essential aspects of the ritual remain: (1) a well-respected man, probably a high-ranking chieftain, has died; (2) a

8 James E. Montgomery, "Ibn Faḍlān and the Rūsiyyah," Journal of Arabic and Islamic Studies 3 (2000), 1-25 at 1-5, but see now Pórir Jónsson Hraundal, The Rus in Arabic Sources: Cultural Contacts and Identity (Bergen: Centre for Medieval Studies, 2013), 92-128, who offers an extensive discussion of Ibn Faḍlān's life and travels.

9 See also Neil Price, "Passing into Poetry: Viking-Age Mortuary Drama and the Origins of Norse Mythology," Medieval Archaeology 54 (2010): 123-56.

10 Abū Zayd al-Sīrāfi and Ahmad Ibn Faḍlān, Two Arabic Travel Books: Accounts of China and India and Mission to the Volga, ed. and trans. Tim Mackintosh-Smith and James E. Montgomery, Library of Arabic Literature 17 (New York: New York University Press, 2014), 246-47.

I I al-Sīrāfi and Ibn Faḍlān, Two Arabic Travel Books, 250-51. 
marriage bed/pyre is ornately prepared for the deceased and a lover; and (3) for the express purpose of facilitating the chieftain's passage into the afterlife, the death ritual hinges upon a sexual union-however gruesome-enacted by the chieftain's men on his behalf.

Setting these medieval sources alongside "The Deacon of Myrká" allows for a comparison of common elements. In both medieval and post-medieval sources, (1) a man of good reputation - a deacon, chieftain, or hero-has died; (2) he is unable to complete his otherworldly journey to the afterlife; consequently, (3) certain burial proceedings are enacted that include the participation of a beloved or bride. In the medieval sources, these include the preparation of a marriage bed/pyre and the accompaniment of a wife, lover, or slave; and in the post-medieval accounts, they include the abduction of the grieving bride. The essential difference between the medieval and post-medieval narratives is that in almost all cases, post-medieval tales like "The Deacon of Myrká," the bride is either terrified of the recently deceased bridegroom and tries to get away or she wants to go with him but is forbidden. In most cases, she survives the encounter. This fundamental difference is telling.

\section{The Pejoration of ATU 365}

One of the important nuances of ATU 365 is that it has never been only about the loss of a lover. These stories are about the loss of a lover and the otherworldly journey the deceased lover takes into the afterlife. If, however, there is any value in the connections between medieval sources and post-medieval tales, then the differences between the early and late traditions indicate a kind of pejoration process in the development of ATU 365. The emphasis and cultural investment in the two components of ATU 365 - the loss of a lover and the journey to the afterlife-changed as time passed, so that a developmental trajectory may be observed. In the sources discussed here, ibn Faḍlān's account offers some indication of what the early, pre-Christian stages of this development might have looked like in the developmental trajectory of these narratives. ${ }^{12}$ That account describes a ritual that is almost wholly concerned with the journey to the afterlife, as indicated by one conversation recounted in ibn Faḍlān's narrative. When the Muslim traveller asks one of the Rūsiyyah why they burn their dead, the latter replies, "We ... cremate them there and then, so that they enter the Garden on the spot," because "My lord feels such great love for him that he has sent the wind to take him away within an hour."13 Of course, the Rūs does not mention here that the dead chieftain is not burned alone but with the female slave who is meant to be

12 It is worth pointing out that it is not necessary that the ritual described by ibn Fadalān be of Scandinavian origin for the connection between it and ATU 365 to hold. It only needs to be an observation of one of the cultures that supports ATU 365. This connection cannot be proven either, but given the broad distribution of the tale type throughout the Indo-European world, it seems reasonable to deduce that there may well be a connection based on comparative analysis.

13 al-Sirafi and ibn Faḍlān, Two Arabic Travel Books, 252-53. 
his lover. But while there is an element of an intimate connection between the female slave to be sacrificed and the chieftain to whom she is bound in death, that element has more to do with the ritual journey the deceased must take than with any sense of romantic commitment on the part of the chieftain or the unfortunate girl. It is clear that the slave is meant to see her sacrifice as a great honour-she volunteers-but it is not because of any apparent love she feels for the deceased. She and the rest of the female slaves have been convinced that to die with the chieftain is a high honour. On this point, a particularly chilling moment in ibn Faḍlān's account occurs when the men outside the ritual ship are instructed to bang their shields and make other noise to cover the screams of the slave girl as she is being murdered, lest the other young women in attendance become reluctant to participate in future rituals. ${ }^{14}$

The Eddic poems "Helgakviða Hundingsbana Önnur" and "Sigurðarkviða in Skamma" represent a midway point along the narrative's trajectory, where the grossly sexualized ritual of ibn Faḍlān's account is transformed into a desperate, romantic commitment on the part of both the bride and the bridegroom. The romantic element thus rationalizes the sacrifice of the slave girl. It is possible that earlier, oral versions of these narratives were coeval with rituals such as that observed by ibn Faḍlān and were used as a kind of script for the ritual. While we have no direct evidence of such a thing, Terry Gunnell's work on the origins of drama in Scandinavia may lend some credence to the speculation. Gunnell is able to argue that poems in the Poetic Edda were once used to support dramatic, possibly ritual enactments of the narratives. ${ }^{15}$ If so, then an oral tradition would, even in the earliest stages, be responsible for romanticizing the ritual sacrifice. ${ }^{16}$ Regardless, at least by the time of the Poetic Edda, the functionality of these death and burial motifs has shifted: whereas the ritual practices in Ibn Faḍlān's account were invested in the well-being of the deceased and in his journey to the afterlife, the heroic narratives in the Poetic Edda invest themselves not only in that journey but also in the grieving beloved who is left behind.

By the time of the post-medieval narrative, the developmental trajectory has severed all ties with any sympathy we may have for the deceased's otherworldly journey. As Ronald M. James observes in reference to Cornish variants of the tale type, "for preChristian society, crossing the line into the supernatural-or at least in this case into the realm of the dead-for romance was heroic. Nineteenth-century expressions of the story generally assert that no living person would want to enter the grave, even when it is the last resting place of a lover." ${ }^{17}$ The same may be said of nineteenth-century versions of the tale in Iceland and, generally, in other cultures. Even in those variants in which

14 al-Sirafi and ibn Faḍlān, Two Arabic Travel Books, 250-51.

15 For an involved discussion of this hypothesis, see Terry Gunnell, The Origins of Drama in Scandinavia (Cambridge: Brewer, 1995).

16 See also Price, "Passing into Poetry," 123-56.

17 Ronald M. James, “'The Spectral Bridegroom': A Study in Cornish Folklore,” Cornish Studies 20 (2013): $131-47$ at 143. 
sympathy with the deceased might remain, the thought of going with the deceased has come to be pejorated. ${ }^{18}$ Acknowledging this pejoration process, however, points to a problem with the development of ATU 365. As the function of the bride's joining her fallen bridegroom in the grave becomes pejorated, the bridegroom's safe conduct during his otherworldly journey to the afterlife is hindered. To put it another way, if the bride does not go with her bridegroom into the grave, then he cannot rest peacefully after death. "The Deacon of Myrká" illustrates the problem quite well, for after Guðrún is saved from her fate that night, the deacon goes on to terrorize her and the farm at Myrká for two weeks. Only when the townspeople enlist the help of a galdramaður, a magician, is the deacon finally laid to rest, and then only after a great struggle in which a large boulder is set upon his grave. ${ }^{19}$

\section{A Theological and Historical Context}

A brief examination of the religious and theological developments in Iceland might offer some explanation of this quandary. It may appear logical that after the conversion and Christianization that took place in Iceland during the medieval period, the new Christian worldview would quickly facilitate a pejoration of such sacrifices, but poems such as "Helgakviða Hundingsbana Önnur" and "Sigurðarkviða in Skamma" attest to at least a lingering appreciation of the romantic aspects of the ritual, as James's observations attest. I suggest that it is Lutheran, rather than Catholic, doctrine and culture that brings about the most significant pejoration of ATU 365 in Iceland, and particular it is a preoccupation with Hell that does so. B. S. Benedikz has argued that post-Reformation Iceland experienced such a preoccupation with Hell due to what amounts to faulty Lutheran theology. According to Benedikz, post-Reformation Icelanders' "minds were fed by ill-trained priests, most of whom were no better off than themselves physically or spiritually, with an ill-digested adulterated Lutheranism which passed for theology in which Hell became of greater importance than Heaven." ${ }^{20}$ During the sixteenth and seventeenth centuries, Iceland struggled to overcome poor food supply and Danish oppression, which drove Icelanders into what Benedikz calls the "slough of mental and physical degradation." ${ }^{21}$ With Reformation came a redoubled effort to stamp out any suspect moral turpitude in the country, and the effort prompted a more aggressive and, importantly, a much more corporeal approach to governing morality. The Alping, the Icelandic parliament, passed the Stóridómur (The Great Verdict) in 1564, a law put forward in an effort to secularize punishment of immorality, which invoked an immediate

18 See Child, English and Scottish Popular Ballads, no. 77 A-C (3:226-34) for variations on this theme, in which, when the bride desires to go with the deceased bridegroom, it is typically the bridegroom who charges her not to come.

19 JÁ 1:272.

20 B. S. Benedikz, "Introduction," in Legends of Icelandic Magicians, ed. Jacqueline Simpson (Cambridge: Brewer, 1975), 2.

2 I Benedikz, “Introduction," 2. 
and tangible punishment that had not been immediately present in the Catholicism of Iceland.

Regarding the theology of post-Reformation Iceland, Jack P. Cunningham looks at the broader landscape, both politically and theologically, of Icelandic Reformed religion to argue that the Reformation succeeded in Iceland due in part to the significant developments in Denmark and in part to the fairly minimal theological changes brought about by Icelandic Reformers. Cunningham argues that these minimal theological changes reflect "a deliberate ploy of the Reformers," who wanted to make it easy for Icelanders to accept the new theology. ${ }^{22}$ Whether Cunningham is right about the motivations behind the theologically soft Reformation in Iceland, it does seem to be the case that, at least initially, little changed on the ground level of theology, but there were also no remaining Catholic bishops or priests to preserve the old theology. Consequently, and in much the same way that an official-sounding date for conversion does not necessarily signal a society fully Christianized, we must consider whether a process of "Lutheranization" following Reformation might have stretched over a considerably long time after Lutheranism won control of Iceland in $1550 .^{23}$

The first real, ground-level theological changes in Iceland were not enacted for another twenty years. It was the prolific bishop of Hólar, Guðbrandur Porláksson (bishop from 1571 till his death on July 20,1627), who made the first fruitful efforts to re-educate Icelandic lay population. Guðbrandur was greatly helped by the introduction of the printing press to Iceland, ${ }^{24}$ which allowed him to write a series of texts that were relatively easy to reproduce. Not least, he oversaw a translation of the Bible into Icelandic, known as Guðbrandsbiblía, which was completed in 1584 and was in use for some considerable time to follow. ${ }^{25}$ With the publication of his Vísnabók Guðbrands in 1612, Guðbrandur also offered a Christian response to what he saw as the rising problem of secular poetry on all manner of unsavoury topics, including rímur (long, complicated narrative poems) that were often retellings of medieval romances and heroic sagas. ${ }^{26}$ If we view Guðbrandur's efforts as the establishment of Lutheranization in Iceland, then the process took at least one generation. As important a figure as Guðbrandur was, however, there is reason to say that the Lutheranization process in Iceland was not fully complete, at least on the ground level, until the life and works of another Icelandic Lutheran bishop, Jón Porkelsson Vídalín (1666-1720,

22 Cunningham, “Changing Fashions,” 67.

23 For information on the Icelandic Reformation, see Vilborg Auður Ísleifsdóttir, Siðbreyting á Íslandi 1537-1565 and Guttormsson's comprehensive study of the history of Christianity in Iceland, Frá siðaskiptum til Upplýsingar. In English, see Gunnar Karlsson, Iceland's 1100 Years, 128-48 and 169-72, and Cunningham, “Jón Arason," 245-73 and “Changing Fashions," 65-92.

24 The printing press was first introduced by Jón Arason, who seems to have made good use of it. See Gunnar Karlsson, Iceland's 1100 Years, 136.

25 Gunnar Karlsson, Iceland's 1100 Years, 136.

26 Gunnar Karlsson, Iceland's 1100 Years, 137. 
bishop of Skálholt from 1697 till his death). Jón Vídalín’s contribution was important to the Lutheranization process not because his theology was materially different from that of his predecessors but rather because his message much more effectively made it into the hands of Icelanders. Jón Vídalín's Vídalínspostilla-a set of sermons, one for every day of the year and various major church festivals (published in 1718 and 1720$)^{27}$-were much more likely to become a part of the average Icelander's daily life than the Bible, which during this time was not present in every Icelandic household because it was too expensive. ${ }^{28}$ It was difficult, especially in the winter, for many Icelanders to travel to church for Sunday services on a regular basis. Even in the summer months, the long distances between farms made it difficult. In lieu of regular church attendance, weekly—and, in the winter, nightly-worship was held in the home, and Vídalínspostilla became arguably the primary text for such "services" from the time of its publication till well into the nineteenth century. ${ }^{29}$

As was discussed in the Introduction, these nightly services were in reality just one part of a much more important Icelandic tradition. ${ }^{30}$ The kvöldvaka, or the "night wake," was an occasion when families gathered together during the evening on farmsteads across Iceland to tell stories, read from the classic medieval sagas, sing songs, recite rímur, and read from religious texts such as Vídalínspostilla. The kvöldvaka was both a form of entertainment and a means of worship; it was a key factor in intermingling classic medieval saga materials with life and culture long after the end of that era. As Emily Lethbridge stated recently, "the kvöldvaka ... meant that orality, or 're-oralization', was still central to the transmission of written texts even up until the nineteenth century in some parts of Iceland." ${ }^{31}$ As an anthropological phenomenon, the kvöldvaka indicates that there were regular, widespread familial and social gatherings in which narrative genres, literary works, and theological perspectives intermingled. As a literary and folkloristic phenomenon, the kvöldvaka thus justifies serious consideration of whether and how religious and secular narratives might display a significant exchange

27 For a thorough discussion of Jón Vídalín and Vídalínspostilla, see Gunnar Kristjánsson "Inngangur," in Vídalínspostilla: Hússpostilla eður Einfaldar predikanir yfir öll Hátíða og Sunnudagaguðspjöll árið um Kring, ed. Gunnar Kristjánsson and Mörður Árnason (Reykjavík: Mál og Menning, 1995), xv-civ.

28 Sigurdur Arni Thordarson, Limits and Life: Meaning and Metaphors in the Religious Language of Iceland (New York: Lang, 2012), 59.

29 There were other postilla, but none of them had the widespread influence that Vídalínspostilla could boast. See Gunnar Karlsson, Iceland's 1100 Years, 171, and Thordarsson Limits and Life, 59.

30 For more on this tradition, see Magnús Gíslason, Kvällsvaka: En isländsk kulturtradition belyst genom studier $i$ bondebefolkningens vardagsliv och miljö under senare hälftan av 1800-talet och börgan av 1900-talet, Acta Universitatis Upsaliensis, Studia Ethnologica Upsaliensia 2 (Uppsala: Almkvist and Wiksell, 1977).

3I Emily Lethbridge, "Gísla saga Súrssonar: Textual Variation, Editorial Constructions and Critical Interpretations," in Creating the Medieval Saga: Versions, Variability and Editorial Interpretations of Old Norse Saga Literature, ed. Judy Quinn and Emily Lethbridge (Odense: University Press of Southern Denmark, 2010), 123-52 at 125-26. 
of ideas between one another. Jón's Vídalínspostilla was a central, vital contributor to the kvöldvaka in both anthropological and literary terms. ${ }^{32}$

There was doubtless a wealth of sixteenth- and seventeenth-century Icelandic oral folk narratives and legends that rankled leaders of the Lutheran church. We may remember that Guðbrandur Porláksson was quite concerned that these heterodox tales, poems, and songs might obscure the minds and hearts Icelanders. ${ }^{33}$ Considering the importance of the kvöldvaka, he was probably right to be concerned. These "unprofitable songs" were in many cases later, post-medieval manifestations of medieval narratives from the fornaldarsögur (legendary sagas), Íslendingasögur (Icelandic family sagas), and Eddic poetry, which themselves purported (whether accurately or not) to be holdovers from a pre-conversion and Christianization age in Iceland and the medieval North. ${ }^{34}$

We thus have three cultural-religious phenomena taking place at once: (1) a growing preoccupation with Hell, death, and the afterlife; (2) a changing religious landscape that has not been adequately established to address the fears and needs of a population preoccupied with Hell; and (3) the cultural venue of the kvöldvaka, in which theology, folk narratives, and ancient sagas are intermingled. This latter cultural phenomenon, the kvöldvaka, afforded Icelanders a weekly (or nightly) opportunity to talk, read aloud, and tell stories about those matters of belief that concern them most. Those stories and discussions would have invariably been informed by Lutheran doctrine, but they could just as easily have been merged with the lingering folk belief of the day. This was the cultural-religious environment in which "The Deacon of Myrká" was told, a story that had its roots in an ancient and widespread Proto-Indo-European tale type that was sufficiently influenced by a muddled Lutheran message to pejorate the one part of the story that was truly reprehensible in Christian eyes: the willingness of the bride to be gruesomely murdered for the purpose of securing the bridegroom's peaceful transition into the afterlife. The most felicitous way around this problem in the post-medieval tales was to transform the recently deceased - who was a "good man" in the ancient pagan ritual and the romantic, heroic narratives of the medieval sources-into an evil, disgruntled creature after his death, who must be defeated rather than comforted in his death. Doing so comes with its own problems, however, as it seems to have left a gap-an unmet need,

32 For my reading of Vídalínspostilla, Thordarson's Limits and Life has been an invaluable resource. Interested readers may also consider Arne Möller's Vídalínspostilla (Copenhagen: Gyldendalske Boghandel Nordisk Forlag, 1922), and the Introduction ("Inngangur") to the recent edition of Vídalínspostilla cited above. For an English translation of selected sermons, see Jón Vídalín, Whom Wind and Waves Obey: Selected Sermons of Bishop Jón Vídalín, trans. Michael Fell (New York: Lang, 1998).

33 See above, 15-17.

34 For a discussion of this topic, see Driscoll, Unwashed Children; Eric Shane Bryan, "Icelandic Fylgjur Tales and a Possible Old Norse Context: A Translation and Discussion of several Icelandic Folktales," Heroic Age 13 (2010), www.heroicage.org/issues/13/bryan.php; Eric Shane Bryan, "Conversion and Convergence: The Role and Function of Women in Post-Medieval Icelandic Folktales," Scandinavian Studies 83 (2011): 165-90; Bryan, "Prospective Memory of Death and the Afterlife." 
so to speak-in the folk tradition for stories about people who die and do not become evil creatures after death. Surely some (or most?) people die peacefully and go to Heaven when they die. What of them? Is Church doctrine enough to accommodate the cultural memory of the afterlife, or do stories arise of these more fortunate folk as well?

\section{Discursive Tales as Adjacency Pairs}

The field of linguistics may be of help here. The concept of adjacency pairs has its origins in linguistics, where it may be described as a pair of utterances in which the cultural context, customs of communication, and speech situation of an utterance determine that the first part of a verbal exchange be followed by a second part that fits well with it. For instance, the phrase Hello, how are you? might be followed by the adjacent phrase Just fine, thanks ... and you? The context of the discourse and the first part of the exchange work together to create an environment in which the second part of the exchange is appropriate and even expected. ${ }^{35}$ In a similar way, while the connections between "The Deacon of Myrká" and the Dead Bridegroom tale type reveal much about the cultural memory imbedded in the tale, a study of cultural memory also benefits from a proper understanding of how the tale might be in "dialogue" with other tales. Inasmuch as a particular tale draws from its past, it may also respond to other stories from the same cultural context. In this sense, one tale might have developed and thriven in a culture not just because it was believed to be true but because it was a necessary-as the cultural context demanded-reaction to an existing story, and, given that context, created a folkloristic version of an adjacency pair.

\section{Adjacency Pairs for "Djákninn á Myrká”}

An adjacency pair in which one tale, tale type, or motif is discernably responding to another due to its specific external context may be evident in the tradition of "The Deacon of Myrká." Within this notion of adjacency pairs, in fact, we may find ways in which other tales answer that lingering question about the story of the deacon-why the deceased would be transformed into something evil in death.

There are five other Icelandic variants of the deacon story that fit into the category of ATU 365 and address these questions in some way. ${ }^{36}$ All of them retain the detail that the deceased suitor uses Guðrún's nickname, Garún, because they cannot say the name of God, Guð, embedded within her full name. ${ }^{37}$ They also respond to the lingering question of the lover's posthumous evil by intimating or stating overtly that the motivation for the haunting is that the woman has scorned his love in some way. While this answer resolves the question of the lover's evil, it represents quite a departure from

35 See Stephen C. Levinson, Pragmatics (Cambridge: Cambridge University Press, 1983), 302-304.

36 These may be found in JÁ 1:272-3, 1:273-74, and 3:352-53; Maurer, Isländische Volkssagen, 73; Einar Ólafur Sveinsson, Verzeichnis Isländischer Märchen-varianten, 33.

37 As Jacqueline Simpson also notes, Icelandic Folktales \& Legends, 150. 
the usual international trend, which tends to depict the two principal figures in the story as being genuinely in love. In some cases, the lover cares deeply about the wellbeing of his beloved, despite the fact that he has come back from the dead. In others (Child 77A and B, see below, 44), it is the beloved's idea to follow the lover in death (not unlike Brynhildur's desire to follow Sigurður into the afterlife), but he even attempts to stop her.

Another group of Icelandic folktales depicts visitations from the recently deceased in more of a sentimental than a sinister light. In several instances a recently deceased person appears in a dream or as a ghost in order to tell a loved one something about their death. These rather formulaic stories typically comprise a brief prose contextualization of events leading to a tragic death, followed by a four- to six-line poem that describes the circumstances of the death and the deceased's prospects for the afterlife. The tale "Dapur er dauðinn kaldi" (Dreary Is Cold Death) ${ }^{38}$ serves as a particularly nice example. At around seventy-five words, the story offers a brief description of a man's death by drowning having gone out fishing with several others. That night his mistress (unaware of his death) dreams that he comes to her and speaks the following verse:

Mjög var órótt pá að dró nótt.

Dapur er dauðinn kaldi.

Mig par að bar sem margur var

Á lifandi manna landi. ${ }^{39}$
All was quite restless as the night dragged on.

Dreary is cold death.

I was taken there where many are,

To the land of the living.

The poem displays a certain morbidity in the first two lines, but in the end it offers consolation and hope to the grieving bride: lifandi manna landi (to the land of the living) must allude to a peaceful afterlife if it is not a specific naming of the Christian Heaven. The mourner can rest assured that her beloved is in good hands and can hold onto the prospect that she will see him again. Most importantly, the bridegroom neither tries to deceive the bride nor use force to take her with him, nor even to convince her in any way to come with him. He simply leaves. He needs no assistance or sacrifice to bring about his otherworldly journey into the afterlife. His sole purpose in appearing to the bereaved is to ease their pain. In all other respects, these tales mirror the formula of ATU 365: A well-respected man has died tragically away from home; the beloved (or a loved one) is unaware of his death until he arrives in a dream or as a ghost. Yet, after all is said, he leaves to go on his otherworldly journey on his own.

A particularly interesting poem in this group refers to a historical personage, a Reverend Porlákur Pórarinsson who lived in Iceland from 1711 to $1773 .{ }^{40}$ The tale only

38 JÁ 1:224.

39 JÁ 1:224.

40 For more on Reverend Porlákur, see Oscar Clausen, "Prestasögur: Dulspakur klerkur og forvitri," Lesbók Morgunblaðsins 41 (January 16, 1966), 4 and 12, https://timarit.is/page/3289742\#page/ n3/mode/2up. 
offers a single sentence as introduction, saying that the night after the death of Reverend porlákur, he visits a girl close to him (though not a lover) and speaks the following verse:

Dauðinn fór djarft að mér,

dauðanum enginn ver;

dauðinn er súr og sætur,

samt er hann víst ágæutur

peim sem í drottni deyja

og dóminum eftir preyja. ${ }^{41}$
Death handled me roughly,

against death there is no defence;

death is sour and sweet,

yet it is surely fine for

those who die in the Lord

and subsequently wait for judgment.

For eighteenth-century Icelanders, a theological connection to the story of Porlákur's death would have been reinforced by the songs of the famous Icelandic hymnist, Hallgrímur Pétursson (1614-1674). One of his most popular hymns, for instance, follows the trajectory of Jón Vídalín’s theology:

Með sínum dauða hann deyddi

Dauðann og sigur vann,

Makt hans og afli eyddi.

Ekkert mig skaða kann.

Pó leggist lík í jörðu

Lifir mín sála frí.

Hún mætir aldrei hörðu

Himneskri sælu í. ${ }^{42}$
With his death he put death

to death and won the victory.

Its strength and power destroyed,

Nevermore can it hurt me.

Though my body be laid in the earth

My soul lives on free.

It will never meet with harshness,

In blissful eternity.

Based on this comparison, the tale of Porlákur's death suggests no conflict between accepted Church doctrine and the fact that Reverend Porlákur appears in a dream. After all, there is nothing heterodox about supernatural events. In fact, the validity of Christian doctrine hinges upon the one all-important supernatural events of Christ's birth, death, and resurrection, and further encompasses a plethora of supernatural events. Thus, the convergence we see here of ATU 365 and Christian doctrine would not be alarming to the Christian lay person in eighteenth-century Iceland, provided that the supernatural events recorded in the tale did not diverge into pagan or otherwise heterodox belief systems.

The aforementioned tale of Reverend Porlákur's death and posthumous visitation in a dream would not seem to qualify as one of the unprofitable songs to which Guðbrandur refers, but other stories about him certainly would. Porlákur lived in Hörgárdalur, Iceland, from 1711 to 1773 . Though perhaps not properly a galdramaður, a magician, Porlákur Pórarinsson was known to have the gift of second sight (ófreskisgáfur) and

4I JÁ 1:223.

42 Hallgrímur Pétursson, Hallgrímskver: Sálmar ok Kvæði (Reykjavík: Leiftur, 1944), 230. 
was said to see huldufólk, or hidden people (whom we might call elves), in Eyjafjörður and other places. ${ }^{43}$ Perhaps not insignificantly, he was believed to have some talent for quieting troublesome ghosts, ${ }^{44}$ and known for unusual methods of healing. ${ }^{45}$

He is said, also, to have known the details of his own death, which is quite a remarkable story in itself. Premonitions about one's own death or the deaths of others are a commonly used literary topos or folkloristic motif in Iceland, ${ }^{46}$ both before and after the Reformation, but this example offers particular insight. Porlákur knew he would drown while crossing the river Hörgá at a certain ford. As the story goes, ${ }^{47}$ one day as he was leaving the church after a gathering, he came across a beautiful red foal tied to a post. Bystanders noticed that he was uncharacteristically interested in the foal, and after examining it carefully, Porlákur sought out the owner and begged him to sell him the horse. From then on, this red foal became Porlákur's saddle horse, and it was on this horse that he drowned in the Hörgá. On the day of his death, he rode out with a companion, came to the ford and asked his companion to wait a moment. Porlákur got off his horse, prostrated himself on the bank and prayed; after a time, he rose, mounted the red foal, and told his companion to proceed ahead of him. As his companion reached the opposite riverbank he looked back to find the foal in the middle of the river, riderless. The important implication here is that Porlákur knew, because of his second sight, the appearance and features of the horse upon which he was to die and, rather than trying to escape his fate, he made efforts to secure it by obtaining the horse.

It must be stressed that Reverend Porlákur was, as I have said, a historical person, and he lived in Hörgárdalur, in the north of Iceland. In fact, it is not at all insignificant that Reverend Porlákur lived and died on the very same river, not fifteen kilometers from the site where the deacon of Myrká is said to have died. This means that in the same region, on the same river, just a short horse ride away, we have one active narrative that represents the pejorated version of ATU 365 ("The Deacon of Myrká") and another narrative (about Porlákur) that not only fills the functional void left by the pejorated ATU 365 but does so by joining aspects of ATU 365, with its roots in paganism, with the dominant religious infrastructure of the day. In the one tale, we have a pejorated, aborted otherworldly journey into the afterlife; in the other, we have the fulfilment of that otherworldly journey, free of the pejoration present in ATU 365.

\section{Adjacency Pairs in the Bear's Son Tales}

Adjacency pairs of this kind are neither new nor uncommon in the development of beliefs in the North. One of the most important adjacency pairs occurs in the stories

43 JÁ 3:20 and 434, 3:588-89, 4:243, 5:463-64.

44 JÁ 3:588 and 3:589.

45 JÁ 3:589.

46 Margaret J. Cormack, "Saints and Sinners: Reflections on Death in Some Icelandic Sagas," Gripla 8 (1993), 187-218 at 189.

47 JÁ 3:434. 
that make up the tale type known as Bear's Son tales, which is so prevalent throughout the northern world. An intriguing Icelandic folktale entitled "Gullbrá og Skeggi í Hvammi" (Goldbrow and Skeggi in Hvammur) ${ }^{48}$ represents a nineteenth-century manifestation of this adjacency pair at work in this group of tales, but the origins of the story reach back to the earliest of Norse stories and pass along the way through stories about conversion from paganism to Christianity. The function of certain motifs in the narrative also illuminates an important discursive mechanism in the development of the folktale. The tale is divided into two distinct parts, ${ }^{49}$ of which the first (addressed more fully in the next chapter) tells the story of a conflict between Auður djúpuðga Ketilsdóttir and the evil troll-woman Gullbrá, who takes over a portion of Auður's land at Hvammur. Auður was a prominent early Icelandic settler in the Hvammur region of Iceland, well known not only for being a strong female leader during the Icelandic settlement period but also for being a Christian in an otherwise pagan country. Another series of conflicts with Gullbrá occur in the second distinct part of the tale, this time between Gullbrá and an expressly pagan figure named Skeggi, who, according to the tale, is the son of Friðgerður, a famous practitioner of Norse paganism and vocal opponent of Christianity featured in Kristni saga (generally known as The Story of Conversion)..$^{50}$

By the end of the first half of the story, Auður has trapped Gullbrá within a series of crosses set up around Gullbrá's land (the final barrier is to be Auður's own body, which is buried in such a way as to block Gullbrá's only remaining exit from the space). Gullbrá tries to escape by having her servants bind her eyes and lead her on a horse out of the land, up toward the slopes leading to the nearby heath. She brings with her a precious chest of gold, but as she passes by one of the crosses, the chest tumbles from her lap.

48 JÁ 1:140-44. Collected from Jón Porleifsson (1825-1860).

49 In fact, the manuscript sent to Jón Árnason presents them as two related but distinct tales, even though Jón combined them to create a single narrative. Jón's change makes logical sense to a degree due to the closeness of the two tales. See below, 51-54 for more on this story.

50 The tale seems to contain an error here. It describes in some detail the scene in Kristni saga, chap. 2, in which the missionaries Porvaldur and Bishop Friðrekur are mocked by a boy named Skeggi, son of the pagan woman Friðgerður, who was conducting a blót (sacrifice) at the time of the missionaries' arrival in Hvammur. However, the tale mistakenly refers to Pangbrandur instead of Porvaldur. Porvaldur's missionary efforts spanned from 981-985, while the later missionary Pangbrandur was not active until 998/999. The later folktale reads: "Pess er getið í Kristnisögu og víðar að pá er Pangbrandur prestur fór um Vestfirði pá kom hann að Hvammi; var máli hans par illa tekið; húsfreyja kom eigi út og var inni að blóti; en Skeggi son hennar gjörði gabb að peim Pangbrandi á meðan" (It is told in Kristi saga and many other places that when the missionary Pangbrandur went around the Westfjords, he came to Hvammur; he was not received well; the housewife at the farm [that is, Friðgerður] did not come out and was inside at a sacrifice, but Skeggi, her son, mocked Pangbrandur and company in the mean time"; my italics). The error is also present in the manuscript Handrit af Jón Porleifsson, Lbs. 531 4to. It is perhaps most prudent not to try to make more of the error than we ought. One can imagine how easy it might have been to confuse the two names. 
Desperate to save it, she tears the blindfold from her face, cursing the ring on which the gold chest hung, ${ }^{51}$ but when she sees the cross barrier, her eyes are gruesomely burned. She finally reaches her new abode (in a dreadful valley) but suffers constant pain from the ordeal until she finally dies from her wounds. On her deathbed she asks her servants to bury her in a deep hole under a violent waterfall, which flows in a dark valley. There, neither light nor church bells can trouble her.

As John McKinnell has noted, the second part of the Gullbrá narrative fits well the well-known Bear's Son tale type, so prevalent in medieval Scandinavian sources, ${ }^{52}$ which R. W. Chambers and others reference in the early studies of Beowulf and Grettis saga. ${ }^{53}$ The shift from Gullbrá's original abode to her final "resting" place results in a narrative landscape perfectly situated to follow the Bear's Son story. Chambers enumerates the steps in this tale type as:

1. A hero sets out on an adventure with companions;

2. the hero resists a supernatural being in a house;

3. guided by the creature in some manner (often a trail of blood);

4. the hero is lowered by a rope;

5. overcomes a different underworld foe, victory often attained by the use of a magic sword found below, and finally;

6. the hero is left by those who were supposed to lift him up again.

5I This is quite an interesting detail in itself. According to the tale, Gullbrá curses the ring, saying that it will now be put to some use that she did not intend. The narrator breaks in to say that the ring then became the door handle for a church in Hvammur. A long description is given of the ring, which is very old, worn down copper plated with a picture embossed on it of two figures wearing armour and one with a pointed weapon (a lagvopni) thrust through his chest so that it comes out of his back. The narrator then links the tale to Kristni saga, saying that the woman who harangued Porvaldur was in fact the mother of Skeggi, who laughed at Porvaldur and his companion (Kristni saga, 9 , and see footnote 50 above). It is impossible to say definitively what the association between the two stories might be. The geography as described in both tales corresponds well enough to suggest some connection, which at least contributes verisimilitude and the possibility of oral transmission, but the tale is in no way dependent upon the association, so much so that Powell and Magnússon do not even include the excerpt in their translation of the tale. Nevertheless, it bears testament to the importance of the association between the struggles of pre-conversion Iceland and those of the later belief structure. They are all of a piece.

52 John McKinnell's Meeting the Other in Norse Myth and Legend (Cambridge: Brewer, 2005), 134-35.

53 See R. W. Chambers, Beowulf: An Introduction to the Study of the Poem with a Discussion of the Stories of Offa and Finn, 3rd ed. (Cambridge: Cambridge Unuversity Press, 1967), 62. See McKinnell, Meeting the Other, 132-35. For further connections, see Magnús Fjalldal, "Beowulf and the Old Norse Two-Troll Analogues," Neophilologus 97 (2012): 547-48, doi:10.1007/s11061-012-9328-y; and Magnús Fjalldal, The Long Arm of Coincidence: The Frustrated Connection between Beowulf and Grettis saga (Toronto: University of Toronto Press, 1998). For a more comprehensive list and assessment of Bear's Son examples in literature and folklore, see J. Michael Stitt, Beowulf and the Bear's Son: Epic, Saga and Fairytale in Northern Germanic Tradition (New York: Garland, 1992). 
The Gullbrá narrative differs in one important way from traditional Bear's Son tales, particularly in step five. After her defeat at the hands of Auður, Gullbrá retreats to her hidden abode, dies, and becomes an afturganga, a ghost who roams the region killing livestock and the occasional farmhand. As the battle begins, the audience realizes that, unlike Auður and Gullbrá, Skeggi and Gullbrá have much in common: they are both pagan (of a sort), both practise witchcraft (though Gullbrá seems more proficient than Skeggi), and both seem to love gold. Skeggi, however, has no malice in him, and his desire for Gullbrá's gold does not seem to carry with it the greed that Gullbrá harbours. Wanting to put a stop to Gullbrá's hauntings, Skeggi waits for favourable enough weather to travel to the gully where she is buried. Here the indications of a connection with the Bear's Son tale begin to show. Skeggi travels with two companions to Gullbrá's lair, representing the first, albeit very general, step that the hero travels with companions. The story then hints at step 2, the hero initially resists the supernatural foe, when he is lowered by his two companions and fights with Gullbrá in her lair. As the struggle takes place, Skeggi's companions are so frightened by the horrible noises below that they nearly abandon Skeggi. Just as they are about to flee, however, Skeggi gives the signal to pull up the rope (which is attached to the chest of gold), but just before they get it to the top, they see an awful spectral fire that rises above the heights of the mountains. Unable to stand any more, his companions flee, finally abandoning Skeggi (step 6) and the gold. Skeggi escapes but cannot subdue the afturganga, taking the story back to steps 2 and 5 . He must again fight Gullbrá, who, according to the tale, seems to have doubled in strength.

Step 5-that the hero achieves victory in the second battle by means of a magic sword, which he finds in the cave below-warrants careful consideration, because here the notion of an adjacency pair begins to come into focus. Step 5 in fact seems at first to have little bearing on the tale about Skeggi, as he does not find any weapon in Gullbrá's cave. Put in the proper context, however, step 5 becomes one of the more significant moments in the tale. Skeggi recovers and makes another attempt to overcome Gullbrá. Three days later, Skeggi returns, near-dead but with the chest of gold, and says that he has killed the troll and is himself dying. On his deathbed he explains that a portion of the gold should be used to build a church at Hvammur because the Christian god helped him when his pagan gods would not. He explains that when he struggled with Gullbrá the first time, he called upon Pórr for help but the pagan god did nothing for him. He then says that the second time they fought, he promised the Christian god that he would build a church at Hvammur if he succeeded. Immediately after calling to the Christian god, a bright light turned the troll to stone. In Beowulf, as in many other Bear's Son tales, the hero finds himself in a similar situation to Skeggi here. Beowulf has been given the sword Hrunting by Unferð (ll. 1455-64), but it fails Beowulf in his fight with Grendel's mother (ll. 1522-28). Instead of a sword, it is a god that fails Skeggi, and the magic weapon he discovers is not another sword but another god, the Christian god.

Some profound change has taken place in the legacy of the Gullbrá story, in which a Christian evangelical message replaces the finding of a magical sword. While it is a fascinating development in the Bear's Son tale type, this substitution of an appeal to the Christian god has a long history in Norse sources. The fourteenth-century Bárðar saga 
Snæfellsáss (The Saga of Bárður, the God of Snæfell), for instance, offers a specimen of the Bear's Son tale type similar to the Gullbrá narrative. ${ }^{54}$ In Bárðar saga, Gestur, the leader of a band of warriors sent to fight the evil king Raknar, enters Raknar's burial mound but soon finds himself in dire straits. Gestur first calls on his pagan troll father, Bárður "Snæfellsás" (the god of Snæfell), who appears but who can do nothing to help. Gestur then vows to take the Christian faith if he leaves the mound alive. King Óláfur Haraldsson, who sent Gestur and the party on their quest, magically appears in the mound carrying a great light that stuns Raknar and gives Gestur the victory. True to his word, Gestur is baptized shortly thereafter, much to the dissatisfaction of his father, Bárður, who appears to Gestur in a dream the night after his baptism. After telling his son that he lacks character for abandoning his forefathers' faith, Bárður puts his hands over his son's eyes and seems to curse them to burn out of their sockets. Gestur dies of the wounds, still in his baptismal clothes. Though Skeggi decides not to convert whereas Gestur does, both suffer in their own way. More importantly, the currency of exchange between the "helping" force has become conversion in both narratives: Gestur converts himself, and Skeggi converts the landscape. The prevalence of the Bear's Son tale type in Icelandic sources suggests that this type of narrative was well-known in literate and oral cultures alike, ${ }^{55}$ so the narrative type was sufficiently well known that the key shift in the Bear's Son narrative-going from a pagan magical helper to an explicitly Christian one-was likely recognized throughout the folk culture, literate or not, and was maintained centuries after the earliest evidence of it. The detail about a great light saving the hero is consistent between the earlier and later sources, as well.

It may be that the presence of the light is the factor that connects the pagan and Christian traditions of the story. For example, in Harðar saga og Hólmverja (The Saga of Hörður and the People of Hólm), another fourteenth-century Icelandic family saga represents another variant of the Bear's Son tale type. ${ }^{56}$ While Harðar saga maintains several similarities to Bárðar saga, in this version the Christian elements do not play an immediate role. Hörður's crew still suffer the problem of digging into the mound, but Hörður has received a special sword from a mysterious man named Björn (bear) that prevents the earth from filling back in. Inside the mound Hörður faces the sinister troll Sóti and overcomes him by asking his companion, Geir, to light a wax candle. The light weakens Sóti sufficiently for Hörður to overcome him. The idea of a saving light, it seems, was either originally a part of some pagan versions of the narrative and later co-opted by the Christian-empowered revisions, or late medieval versions have reverse engineered the motif to fit supposedly pagan versions.

The post-medieval tale about Gullbrá, like the medieval versions that contain the same motif, thus achieves a graceful unity in the end, as Gullbrá's gold pays for the

54 See Stitt, Bear's Son, 116-20 and 146-50; Magnús Fjalldal, “Two-Troll Analogues,” 547-48.

55 See Magnús Fjalldal, Long Arm of Coincidence, 79-116, for an overview of theories concerning relationships between respective Bear's Son texts.

56 For comparisons between the two sagas, see Stitt, Beowulf and the Bear's Son, 150. 
building a church on the land she stole from Auður in the first half of the story. The remembrance of Gullbrá's role as a representative of evil in the Christian sense burns again in high relief when the redemption of the land suggests a promise of the greater redemption to come, compelling the audience to admit the value of conversion. Only Skeggi resists conversion, buried on unconsecrated ground, with the remainder of Gullbrá's gold under his head. His figure leaves the audience anxious about the state of those who hold on to pagan ideas after realizing the power of the Christian god, for they cannot help but wonder whether Skeggi will turn out any better than did Gullbrá. Because of the changeover from sword to god, the structure of the Bear's Son tale here takes upon itself the cultural memory of conversion.

As an adjacency pair, the Bear's Son and Gullbrá narratives establish a discernable dialogue between the earlier examples of the Bear's Son tales and the later. The later versions, making up the group that substitutes the Christian god as the weapon that saves the hero, seem to have developed in response to the earlier versions as a way to emphasize the power and authority of the Christian god. In the Gullbrá narrative, the identification of the pagan hero as Skeggi-a famous pre-Christian figure whose identity is kept alive in the Icelandic cultural memory-enables the adjacency pair to generate a localized cultural memory within the specific history of the region and country.

\section{Final Thoughts:The Deacon of Myrká and the Legacy of Storytelling}

Although the Icelandic folk narrative "Djákninn á Myrká” represents a cultural memory of the time during which it was produced, the narrative does not stand isolated in literary and folkloric history. Both its internal and external contexts point to deep roots in the past. As an example of the folktale type ATU 365, "Djákninn á Myrká" is part of a legacy of belief and storytelling that reaches back to a pre-Christian time. This legacy implies nothing about actual pagan practices or beliefs as they occurred in the preChristian North, but it does suggest that they, whatever they were, were diachronically connected to the post-medieval narratives through this legacy. The pejoration process and adjacency pairs represent two ways that narratives concerning death and the afterlife have been transformed by-and have in turn transformed-cultural memories of death in the medieval and post-medieval North. The development of the narrative from the earliest times to the post-medieval period has undergone a process of pejoration which has brought about what amounts to the demonization of the dead bridegroom in the story. I have furthermore suggested that this fundamental change has left this tale type wanting something and, consequently, a closely correspondent group of tales has arisen, making up a folkloristic "adjacency pair," to fill the void left by the pejoration of ATU 365.

Considerably more work is required to determine whether such adjacency pairs have developed around other examples of ATU 365 throughout the Indo-European world, but a cursory glance at some other traditions suggests that different traditions address the problem differently. Each seems to be compelled to deal with the pejoration of ATU 365 in one way or another. In some, the hostile bridegroom is said to be a rejected 
lover seeking revenge; ${ }^{57}$ in others, the romance of self-sacrifice seen in the Norse poetry remains to some extent, though it is not consummated; ${ }^{58}$ while in still others, a moral lesson of some kind is proposed..$^{59}$ This variation is to be expected in such a widespread tale type, the many variants having been uniquely influenced by their respective cultural context, but there is another, perhaps more important lesson to be taken from the observations made here: folk narratives develop according to the cultural influences upon them. The "Deacon of Myrká" and its adjacent narratives develop in such a way as to create a narrative mechanism by which beliefs about death, Hell, and the afterlife might be accepted, revised, or rejected. It is hard to call these stories "orthodox" according to the post-Reformation doctrine, but that is quite different from saying that they are "pagan" or simply "heterodox." They are a complicated blend of heterodoxy and orthodoxy. These stories indicate a desire to make sense of the religious context in which they were fostered. When a part of the narrative legacy becomes offensive to that context, the narrative suffers a pejoration. When the narrative seems lacking or irrational within that religious context, adjacent narratives or variants crop up to address the pressure of the irrationality or need.

The subsequent chapters of this book will illustrate further examples of this type of blending, pejoration, adjacency pairs, and other ways that the legacies of some of the great Icelandic folktales of the post-medieval period illustrate a developing cultural memory of belief, and, hopefully, some indications of why and how such blending occurred. It is not difficult, however, to imagine how it might have happened. During a long winter night in the north of Iceland, the kvöldvaka-that time of storytelling, hymn singing, and perhaps reading from Vídalínspostilla-is particularly lively at a certain farm near the river Hörgá. Perhaps some guests have come from the neighbouring farm to join the night's festivities, and someone tells the story of the of the deacon who raged so violently after his unfortunate death. No one knows why he turned into such a devil when he died, and it is hard to imagine that he made it to Heaven in the end. Then, thinking about that hymn of Hallgrímur Pétursson's they had sung just a few minutes earlier, someone remarks: Have you heard the story of poor Reverend Porlákur? He died just like the deacon, even on the same river, though he wasn't quite so nasty as the deacon after he died. My grandmother was there and she told me all about it. Here's what happened ...

57 See JÁ 1:272-74; Maurer, Isländische Volkssagen, 73; and Child, English and Scottish Popular Ballads, 77C.

58 Child, English and Scottish Popular Ballads, 77A and B.

59 Gottfried August Bürger, Lenore, trans. Dante Gabriel Rossetti (London: Ellis and Elvey, 1900). 


\section{Chapter 2}

\section{THE ELF WOMAN'S CONVERSION: MEMORIES OF GENDER AND GENDER SPHERES*}

\section{“Álfkonan hjá Ullarvötnum” (The Elf Woman at Ullarvötn)'}

Near the Lakes of Wool in the east of Iceland, a sheep farmer named Andrés lost his entire flock. As this was a grievous loss to the farmer, he sent out servants to find the sheep, but neither sheep nor men returned. Despite his parents' fears for his safety, the farmer's son, Sigurður, determined to go look for the men and the sheep. Sigurður found no sign of them until he came upon a series of lakes where someone had spread wool out to dry, and just then he noticed a flock of sheep grazing on lush, green grass. He approached, feeling sure they were the missing flock, but a beautiful woman met him before he could get very close to the sheep. She greeted him by name (though he was sure he had never seen her before), said that she had taken the sheep and killed all the servants, and that she would surely kill him too unless he agreed to become her lover. The woman-who said she could be called Vandráð or Valbjörg, whichever Sigurður prefers-said she was of elf-kind and that she had lost her parents two years before. No longer did she live with her own kind because her father had prophesied that she would bear the children of a human man. Sigurður, moved by her beauty, grace, and not unimpressed by her elfish powers, agreed to stay with her on the conditions that the flock be sent back to his father and that his father be told that he was alive and well. She agreed, and all was well with the couple for three years.

Sigurður's father, Andrés, was glad to see his flock returned, and while saddened not to have his son come home, he felt a consolation that he was safe and sound, until one night, Sigurður came to his father in a dream and beseeched his father to come to him on the night of Christmas Eve. "When you come," said Sigurður, "bring the Reverend Eiríkur with you, have him stand at the door as you enter, and be sure that he catches and holds fast to the woman who tries to rush out of the house when you enter. Be sure of this, father, for if he lets her go, you will surely never see me again." After explaining where to find him, Sigurður disappeared. Andrés did just as his son had asked, and on Christmas Eve, he followed the directions given to him and came upon their home. He entered the rooms to find his son carding wool while a beautiful woman sat holding a baby. When Andrés entered the room he proclaimed, as was the custom in Iceland at the time, "God be here!" At the proclamation of the name of God, the elf woman went into a frenzy, threw the baby on the bed, and ran from the house, but the Reverend Eiríkur was at the door and ready for her. He clasped his arms around her and didn't let go. For a week thereafter, Eiríkur

* A version of this chapter appeared in Scandinavian Studies 83 (2011): 165-90.

I Adapted from JÁ 1:97-99, from the manuscripts of Ólafur Sveinsson of Purkey (1762-1845). 
confined the elf woman, though she wailed and begged him to free her. Eiríkur was firm but gentle with her, working to quell her anger and violent temperament. After that time, she was somewhat recovered and went home with Sigurður, where they stayed over the winter. The woman improved greatly over that time (though it is unclear whether she took the Sacraments during mass) and had been completely freed from her elfish nature by the spring, when Reverend Eiríkur came to visit them. He joined the couple in marriage, and from then on, they were happy and productive. In fact, it is said that many people admired the woman because she was very charitable, had great virtue as a housewife, and she hated any kind of disagreeability.

The couple is said to have had four children together, some of whom went on to become well known in the country.

This story must be one of the most peculiar in all of Icelandic folklore. It preserves the powerful otherworldliness often associated with the elfish or fairy dwellings in international tales, yet the elf's power and beauty also fit well into Icelandic traditions. Valbjörg's wooing of a human man and aversion to Christianity are likewise not unexpected in Icelandic stories of elves, though elfish women who take human lovers tend to hope their children will be baptized into the Christian church. All this so far fits well into both Icelandic and international motifs associated with stories of the elves, ${ }^{2}$ but the story takes an odd, even unprecedented turn in the second half, when the elf woman is mysteriously freed from her elfish nature and becomes, by all accounts, human. The referend, Eiríkur, seems to exorcise her in some fashion, as the text reads, "vakir prestur yfir henni; er hún stundum í ómegin, en pess á milli er hún að gráta og biðja prest að sleppa sér; en pað gjörir hann ekki" (the priest watched over her through the night; she would faint now and then, and would at times weep and beg the priest to free her, but he did not do it), ${ }^{3}$ and her condition after having been cured is almost picturesque: "Hún var góðgjörandi kona so hún var elskuð af fólki; líka var hún siðferðisgóð á heimili og hataði ósampykki" (She was such a charitable woman that she was much loved by people; she was likewise of great virtue as a housewife and hated any kind of disagreeability). ${ }^{4} \mathrm{Her}$ liberation (as it is depicted) from her elf nature intertwines with gender and religion as well. In fact, the story seems to pit two spheres of gender against one another: in the one sphere, Sigurður, Andrés, and Eiríkur (Sigurður's mother is hardly mentioned) represent masculinity, Christianity, and the normative world, and in the other, Valbjörg represents the feminine, (anti-Christian) elf-hood, and an elfish otherworld. The female sphere-it must be evident-is almost wholly redefined by the male sphere.

As chapter 1 made evident, the kvöldvaka (lit. "night-waking") was a key factor in the cultivation of cultural memory in Iceland because it afforded a context in which stories from an older time could be intermingled with existing religious doctrine. Kirsten

2 I discuss these connections in some detail below (61).

3 JÁ 1:99.

4 JÁ 1:99. 
Hastrup suggests that sagnaskemmtun, or the part of the kvöldvaka when old sagas were read aloud, resulted in the "steady reproduction of ancient images of Icelandic history." ${ }^{5}$ As is observable in the stories discussed in this and the previous chapter, these "ancient images" serve a deeper purpose in cultural memory than just to recall events or even merely to entertain. While they rarely supported Christian doctrine in the strictest sense, ${ }^{6}$ they regularly worked to reconcile those "ancient images" with contemporary Christian life. Furthermore, woven into the images of the past were newly fashioned (but often equally heterodox) images of the supernatural world that required reconciliation as well. The result was a tension between a stricter view of church doctrine, which did not look kindly upon ancient folk motifs, and a view that was not so strict, which welcomed intermingling between folk and Christian belief. ${ }^{7}$ The divide quickly spread throughout cultural memory by way of orally transmitted folk materials, songs, and poetry. ${ }^{8}$ Throughout all of these changes and the blending of interpretation, gender spheres-such as those on display in the story of the elf woman's conversion-were also woven into the mixture. Answering the question of how these gender spheres interact with religious belief will be the work of this chapter. ${ }^{9}$

\section{Gender Spheres in Old Norse Sources}

Scholars have often noted that in Old Norse sources, female historical and literary figures tend to exhibit strong opposition to the conversion to Christianity. Often cited as

5 Kirsten Hastrup, "Iceland: Sorcerers and Paganism," in Early Modern European Witchcraft, ed. Bengt Ankarloo and Gustav Henningsen (Oxford: Clarendon, 1996), 190.

6 The obvious exceptions to this statement are those stories propagated by the religious leaders themselves. Vísnabók Guðbrands (1612) by Guðbrandur Porláksson, for instance, stands as an especially important exception. See the introduction above for my discussion of Guðbrandur and his efforts.

7 Hastrup argues for less of a divide between the elite and popular cultures though she acknowledges a small educated class. In my opinion, post-Reformation Icelandic literature supports a more divided culture than in medieval times. See Kirsten Hastrup, Nature and Policy in Iceland 1400-1800: An Anthropological Analysis of History and Mentality (Oxford: Clarendon, 1990), 190-91. See also my discussion of religious development in the Introduction.

8 See Matthew Driscoll's chapter on "Popular Romances in Post-Reformation Iceland" in his The Unwashed Children of Eve: The Production, Dissemination and Reception of Popular Literature in Post-Reformation Iceland (Enfield Lock: Hisarlik, 1997), 1-33.

9 This chapter attends primarily to the female gender sphere largely because valuable scholarly work has recently been directed toward understanding the relationship of women to old Norse conversion, Christianization, and religious institutions. This scholarly discussion offers a useful and important point of contact with the later folk tradition, which in my opinion must be taken into account in order for the discussion to be considered complete. As may be evident here, the argument could certainly be made that, given the predominance of men in Christian institutions, no aspect of the normative culture therefore remains unaffected by the attributes of the masculine gender. If such is the case, it is all the more reason to examine the role and impact of the non-normative gender. 
support for this opposition are the confrontations between Porvaldur and Friðgerður in Porvalds páttr ens víðforla (The Tale of Porvaldur the Far-Travelled) and Kristni saga as well as Pangbrandur's conflict with Steinunn in Njáls saga. Sources such as these have contributed to the perception of a Christian-male/pagan-female opposition structure that has helped forge our understanding of gender roles in Norse conversion and Christianization. ${ }^{10}$ Some scholars see this opposition structure as evidence of a historical phenomenon involving pagan women during the process of Norse conversion and Christianization, ${ }^{11}$ while others have argued that it functions as a literary construction ultimately reflective of negative ecclesiastical views of women. ${ }^{12}$ Recently, Siân Grønlie has challenged these interpretations, arguing that they tend to overlook narrative accounts that paint women in a supportive, Christian light, adding further, "even when the Christian-male/pagan-female opposition is clearly drawn, it does not always follow that the narrative sympathy, insofar as we can discern it, lies with the Christian-male."13 Rather than a gendered religious opposition, Grønlie observes a topos in Icelandic literature that instead presents a social opposition that bears a gendered imprint. ${ }^{14}$ On one side of the opposition persists a "female sphere," which is private, intimate, based in the home, and opposed to conversion, while on the other stands the "male sphere," which is public, political, legal, and in support of conversion.

One interesting literary example from the thirteenth-century Sturlunga saga warrants further comment. In a brief scene, the famous pagan heroine from Volsunga saga and the Poetic Edda, Guðrún Gjúkadóttir, appears as a dream-woman to the young

10 For overviews of this discussion see Gro Steinsland, "Husfruer, gydjer og volver," in Kvinnenes kulturhistorie: Fra antikken til år 1800, ed. Kari Vogt, Sissel Lie, Karin Gundersen, and Jorunn Bjørgum, 2 vols. (Oslo: Universitetsforlaget, 1985-88), 1:126-30; Ruth Manzo Karras, "God and Man in Medieval Scandinavia: Writing — and Gendering-the Conversion," in Varieties of Religious Conversion in the Middle Ages, ed. James Muldoon (Gainesville: University Press of Florida, 1997), 100-114; and, more recently, Siân Grønlie, “'Neither Male Nor Female'? Redeeming Women in the Icelandic Conversion Narratives," Medium Ævum 75 (2006): 293-318; and Íslendingabók, Kristni saga: The Book of the Icelanders, The Story of Conversion, trans. Siân Grønlie. Viking Society for Northern Research, Text Series 18 (London: Viking Society, 2006), n. 18.

II See, for example, Jenny Jochens, Old Norse Images of Women (Philadelphia: University of Pennsylvania Press, 1986), 79-80; Gro Steinsland, "The Change of Religion in the Nordic Countries: A Confrontation between Two Living Religions," Collegium Medievale 3 (1990-92): 123-35.

12 See, for example, Birgit Sawyer, Kvinnor och Familj i det forn- och medeltida Skandinavien, Occasional Papers on Medieval Topics 6 (Skara: Victoria bokfölag, 1992), and Birgit Sawyer, "Women and the Conversion of Scandinavia," in Frauen in Spätantike und frühmittenlalter: Lebensbedingungen, Lebensnormen, Lebensformen, ed. Werner Affeldt and Ursula Vorwerk (Sigmaringen: Jan Thorbecke, 1990), 263-81; Helga Kress, "Grey pykir mér Freyja": Um konur, kristni og karlveldi í islenskum fornbókmenntum," in Konur og kristsmenn: pættir úr kristnisögu Íslands, ed. Inga Huld Hákonardóttir (Reykjavík; Háskólaútgáfan, 1996), 15-63 (reprinted in Helga Kress, Fyrir dyrum fóstru. Konur og kynferði i íslenskum fornbókmenntum (Reykjavík: Rannsóknastofa í kvennafræðum, 1996), 167-219).

13 Grønlie, "Neither Male nor Female," 295.

14 Grønlie, "Neither Male nor Female," 310. 
woman Jóreiður. The passage proceeds as might be expected in a sequence of visits from a dream-woman, ${ }^{15}$ and contains a mixture of prose and poetry in which Guðrún reports on certain events. In literary terms, Guðrún's usefulness to the story appears have more to do with allusions to her own story ${ }^{16}$ than with the fact that she is a pagan hero. Be that as it may, the saga writer seems to anticipate an objection on the part of the audience to a pagan speaking into a Christian world and thus gives an answer to the objection.

Judy Quinn has noted that the narrative works hard to contribute a Christian context to the passage,${ }^{17}$ which opens by giving the dreams at least the veil of a Christian context, saying, "Petta dreymdi hana Jóreiði sextán vetra gamla par í Miðjumdal um messu, Maríumessu Magðalenu, í kirkju" (The sixteen-year-old Jóreiður dreamed this in the church at Miðjumdalur during the Mass of Mary Magdalene). ${ }^{18}$ Later Jóreiður sees her dream-woman (who at this point remains anonymous) dressed in a black cloak riding a grey horse. Jóreiður asks who she is, and when Guðrún tells her, she responds, "Hví fara heiðnir men hér?" (What are pagans doing here?). Guðrún replies, "Öngu skal pið pað skipta ... hvort eg em Kristin eða heiðin en vinur em eg vinar míns” (That should not concern you at all ... whether I am Christian or pagan, but I am a friend to my friends) ${ }^{19}$ The questioning then moves on to the more relevant issues concerning the well-being of Jóreiður's family members. Later, Guðrún again references Christianity, when she says, "Nú hefir petta prisvar borið fyrir pig enda verður prisvar allt forðum. Рað er og eigi síður að góð er guðs prenning” (Now this has happened to you three times, since all good things come in threes. It is no less true that God's Trinity is good) ${ }^{20}$ The narrative could easily go without the references to Christianity, and for that reason the appearance of the Christian context indicates something about the expectations of the audience in the mid-thirteenth century. Judging from Jóreiður's reaction when she learns the name of her dream-woman, the question seems to be whether a pagan dream-guide, male or female, can be trusted. ${ }^{21}$ That the events take place specifically on the mass of Mary

I5 See my discussion of dream-women below, 133 and 136.

I6 Julia McGrew's makes note of this point in her translation of Sturlunga Saga, 2 vols. (New York: Twayne, 1970), 1:476. See also Sandra Balif Straubhaar's brief introduction to the scene in Old Norse Women's Poetry: The Voices of Female Skalds (Cambridge: Brewer, 2011), 44. Straubhaar's is furthermore a useful collection and discussion of female skalds from Old Norse poetry.

17 Judy Quinn, “The Use of Eddic Poetry in Contemporary Sagas," Frá Suðlægri Strönd/From a Southern Shore 3 (1987): 54-72.

18 Sturlunga saga, ed. Örnólfur Thorsson and Bergljót Kristjánsdóttir (Reykjavik: Mál og menning, 2010), 674 .

19 Sturlunga saga, 675.

20 Sturlunga saga, 675.

21 Quinn notes that in other places in Íslendinga saga, Valkyries often appear in men's dreams and prophecy about death in battle and therefore do not contradict expectations, but in contrast, in a Christian setting, a (male) bishop tends to appear to a male dreamer to advise him: Quinn, "Eddic Poetry," 59-60. 
Magdalene, rather than just any mass, further feminizes the encounter and further breaks the expectations of the female sphere.

This late medieval representation of the pagan heroine Guðrún Gjúkadóttir serves as a contrast with expectations of male and female spheres: though she is not Christian, she speaks from a Christian perspective into a Christian narrative context. The extra efforts to present her in a Christian context may also point to the expectation of gender spheres, since the narrative works to push Guðrún beyond the expected pagan-female sphere, which she might otherwise appear to confirm. ${ }^{22}$ While there may have once been the expectation that the female sphere would oppose Christianity, in the Christian period even pagan women of the past can be claimed by Christendom. If this reading has any merit, the narrative may point to a shift in gender spheres toward the end of the Christianization period.

\section{Gender Spheres in Post-Medieval Folk Narratives}

At this point, it is worth asking whether and how these spheres might have survived in the later Icelandic cultural memory. The remainder of this chapter seeks to observe these two spheres across a longer view of religious development in Iceland, paying specific attention to the body of Icelandic folklore material collected from the seventeenth to the nineteenth century. ${ }^{23}$ Rather than turning to historical, literary, or archaeological sources, it is worth looking here to the folk record, which also preserves a cultural memory of both cultural and religious developments. ${ }^{24}$ I begin by revisiting the tale entitled "Gullbrá og Skeggi í Hvammi" (Gullbrá and Skeggi in Hvammur) ${ }^{25}$ to explore the first part of the story, in which familiar persons and events from pre-conversion

22 It is impossible to make any definitive assertion on this question, since we are without a matching context in which a male pagan hero appears for a similar purpose.

23 The analysis of later material requires a slight revision of Grønlie's male and female spheres. Rather than speaking of the support or opposition to conversion, as such, in post-Christianization Iceland, the opposition is between Christian orthodoxy and beliefs more on the periphery of Christian doctrine.

24 I have discussed some of the historical discussion that surrounds issues of post-Reformation Iceland above (11-17), but for further context see Hastrup, Nature and Policy, as well as Karlsson, Iceland's 1100 Years for a general overview. For a discussion of Icelandic Reformation, see Vilborg Auður Ísleifsdóttir, Siðbreytingin á Íslandi 1537-1565: Byltingin að ofan (Reykjavík: Íslenska bókmenntafélag, 1997). For an examination of women's social and legal rights in the nineteenth century, see Pórunn Sigurðardóttir, "Saga World and Nineteenth-Century Iceland: The Case of Women Farmers," in Cold Counsel: Women in Old Norse Literature and Mythology, ed. Sarah M. Anderson and Karen Swenson (New York: Routledge, 2002), 281-93. For a study of educational developments in Iceland after the Reformation, see Sigurður Pétursson, "Latin Teaching in Iceland after the Reformation," in Reformation and Latin Literature in Northern Europe, ed. Inger Ekrem, Minna Skafte Jensen, and Egil Kraggerud (Oslo: Scandinavian University Press, 1996), 106-22.

25 An English version of this tale appears in the first volume of Jón Árnason, George E. J. Powell, and Eiríkur Magnússon's Icelandic Legends (London: Bentley, 1864), 113-20, but note that significant portions of the original tale were not included in this translation. 
Iceland appear once again. I then turn to a series of tales about Icelandic magic users ${ }^{26}$ which betray much about the spheres of gender and Christian beliefs, though perhaps more for their lack of a female sphere than for its prevalence. Thus equipped, a deeper exploration of the morphological potency and uniquely Icelandic character of the story about the elf woman's conversion-“Álfkonan hjá Ullarvötnum"27 ("The Elf Woman at Wool Lakes") - opens the door to a vision of the reconciliation between male and female spheres. Analysis of these tales suggests that the gendered spheres observed by Grønlie have not been lost in the later Icelandic folktales. Rather, the tales seem to manipulate the topos to reconcile lingering social challenges of both gender and religion.

\section{The Cultural Memory of Auður hin djúpuðga}

As may be evident from the discussion of early Iceland in the Introduction, the cultural memory of Auður hin djúpuðga (the deep-minded) played an important role in the cultural memory of early Icelandic Christianity and beyond. ${ }^{28}$ Imbedded within this cultural memory, the story of "Gullbrá og Skeggi í Hvammi"29 again places Auður at her farmstead in the Hvammur region, where much Icelandic history begins. No doubt appended by the collector, the tale reminds us that Sturla Pórðarson, "Hvamm-Sturla," and his famous children get their start here, and states that Auður settles in this area upon her arrival to pre-conversion Iceland. ${ }^{30}$ In the early Icelandic accounts, Auður unmistakably challenges the expectation that women oppose Christian conversion. ${ }^{31}$ Not only is she a strong, authoritative woman, but she is also a devout Christian (one of only a few in Iceland at the time), owns land, gives advice, and serves in political roles. Thus, Auður functions perhaps more as a female in the male sphere. Nevertheless, she stands as an early example of the complicated relationship between the two spheres of gender and Christianity.

26 Many of these tales are not yet translated into English, but see Jacqueline Simpson's translation of Legends of Icelandic Magicians (Cambridge: Brewer, 1975) for an representative selection.

27 An English version of this tale appears in the first volume of Árnason, Powell, and Eiríkur Magnússon, Icelandic Legends, 72-80.

28 In fact Auður remained fixed in the Icelandic memory well into the twentieth century. See Vanherpen's very good article "Remembering Auðr/Unnr djúp(a)uðga Ketilsdóttir." Especially noteworthy is Vanherpen's examination of Magnús Friðriksson's 1940 version of the tale, entitled "Hvammur í Dalasýslu," published in Árbók hins íslenzka fornleifafélags (1940): 88-111.

29 JÁ 1:140-44. The Jón Árnason version of this tale is taken from the manuscripts of Rev. Jón porleifsson (1825-1860), but the tale is first mentioned in 1690, in a letter from Árni Magnússon, who lived at Hvammur. See McKinnell, Meeting the Other, 132; Einar Ólafur Sveinsson, Folk-Stories of Iceland, 119.

30 Hvammur is also the site of one of the more famous male Christian/female pagan oppositions, that between the Christian (male) porvaldur and the pagan (female) Friðgerður. See Kristni saga, chap. 2 and Porvalds páttr ens víðförla.

31 The most predominant accounts of Auður hin djúpuðga appear in Landnámabók and in Laxdælasaga, chaps. 5-7. 
"Gullbrá og Skeggi í Hvammi" further muddles the topos, but it does so by manipulating the male and female spheres rather than by dispensing with them all together. Of the tale's two distinct parts, one deals directly with Auður while the other addresses events after her death (which I have discussed in the previous chapter). In the first part, Auður has set aside a certain portion of her farmland as sacred, upon which no crops should grow and no livestock should graze. ${ }^{32}$ The tale acknowledges that Auður, though Christian herself, lives in a pre-Christian Iceland. By reserving this sacred area, Auður seems to anticipate the conversion of the entire country, and the ensuing conflict bears out her foresight. When Auður has grown old, a young and beautiful woman named Gullbrá arrives at Hvammur wanting to purchase the sacred land because, she says, she fears that eventually another Christian church (one already stands on Auður's land) will one day be built on the sacred land. Since Auður is at the time bedridden with an illness, Gullbrá is able to trick the superintendent (a man) into selling her the land for a bag of gold. Typical of Scandinavian folk tradition, the beautiful Gullbrá then reveals her true nature as an evil and ugly troll, and she builds her own temple on her newly acquired sacred land, specifically (even geographically) in opposition to the Christian church already standing on Auður's land.

Thus begins a battle between the two women. The prefigured battle over conversion allows us to examine how a gendered opposition might have progressed alongside Iceland's various religious developments. In simple terms, the cultural memory of Auður hin djúpúgða preserves in a post-medieval Iceland both her status as a strong, exceptional female leader and her role as a representative of Christianity during the settlement period, but several emendations to the original memory cannot be ignored. For one, the later tale revises the expected opposition to Christianity of the female sphere, not just because Auður is a female Christian (as she is in Old Norse sources) but also, in the folktales, because the tale creates a new enemy of Christianity: a troll. Perhaps it is not entirely surprising, given the close association between the post-medieval folk story and the conversion narratives of earlier Icelandic texts, that we again do not find the prevalent conversion opposition of a Christian male figure struggling against a pagan female figure. Here, even more pointedly than in the earlier narratives, we observe a female Christian pitted against the evil, notably female, Gullbrá who has come to thwart conversion. The difference bears special significance due to the association of evil not with just any female, but with a female troll-a mythological figure who, particularly in female form, is well-known in Icelandic oral tradition for being especially sinister. ${ }^{33}$

Closely related to this adoption of a female-female confrontation is the tale's blurring of religious boundaries. At first glance it appears evident that the evil troll Gullbrá represents paganism and that Auður represents Christian condemnation of the ancient

32 The land is placed under an álag, a "compulsion," or in the more common plural form, álög, the meaning of which is closer to "a spell" or a "curse." An álagablettir is a piece of land own by the huldufólk and is off limits. See Árni Óla’s Álög og bannhelgi (Reykjavík: Setberg, 1968).

33 See for instance Stjúpusögur, JÁ 2:299-381, in which female trolls play an especially sinister role. 
religion. Gullbrá uses strong magic, makes sacrifices of some sort, and her malice is unmistakable. By taking possession of the sacred land, she does indeed forestall the building of another Christian church-hindering the spread of the Christian religion, as it were. Religious affiliations in the tale are complex, however, as Gullbrá offers a more vaguely defined opposition to Christianity, appearing more troll-like than pagan. She is never referred to in terms of ancient religion, and none of her rituals suggest the connection. Even Auður somewhat blurs the line between religions. In one instance, she seems to rely on more than just Christian divine strength, for she states that no harm will come to Hvammur because the land is protected by a good spirit, a fylgja, to use her exact word, a term that, as the following chapter of this book will attest, conjures memories of pagan attendant spirits by the same name. In the post-medieval folklore, it seems, evil does not always directly correspond to ancient paganism, nor does good rely exclusively upon the Christian god.

The point is driven home in the second half of the tale, where gendered opposition becomes further inverted. Chapter 1 offers a thorough examination of the second part of the tale (39-43), but it is worth remembering that a pagan male, Skeggi-according to the tale, this appears to be Skeggi, son of Friðgerður, a famous female opponent to Christianity featured in Kristni saga-takes up the battle against the evil trollwoman. While Skeggi initially turns to several typically pagan elements of heroism and strength, ${ }^{34}$ he finally defeats the troll by seeking help from the Christian god, vowing to build a Christian church at Hvammur in return. Divine assistance immediately comes, and in the end Skeggi keeps his promise to build the church (thus confirming Gullbrás original fear). Interestingly, however, Skeggi refuses to convert to Christianity before his death.

In its entirety, the tale revises gender spheres to produce a male pagan, Skeggi, who refuses to convert despite his collaboration with the Christian god, and a female Christian, Auður, who at times calls on old beliefs. The revision of the gender structure in early motifs is associated with, and in some ways allows for, a softening of Christian hostility against paganism and vice versa, while setting another category-trollishnessas the sphere of evil. This assessment of a "troll sphere" coheres with recent work done by Ármann Jakobsson on the subject of trolls. Ármann concludes that trolls are not a mythological category so much as a designation of otherness and danger. As he puts it,

The troll is danger; what is not dangerous and feared cannot be a troll ... Danger turns the world on its head. Like death it intrudes into the established order, snatches all imagined control from the humans who have set themselves up to be the protagonists of their own lives. Danger becomes an abyss, into which one can feel themself helplessly falling. As an image of danger, the troll cannot be but terrible..$^{35}$

34 In fact the tale reflects the well-known Bear's Son type. John McKinnell outlines this connection, though he is more interested in the second half of the tale: Meeting the Other, 134-35). See my discussion of this point in chapter 1 (39-41).

35 Ármann Jakobsson, The Troll Inside You: Paranormal Activity in the Medieval North (Earth, Milky Way: punctum, 2017), 19. 
Such is the portrayal of the troll sphere in "Gullbrá og Skeggi í Hvammi." In contrast, the tale depicts a paganism that is not so much "evil" as "ancestral," and though not an acceptable part of Christendom, Christianity still allies itself with paganism to defeat the troll. Ultimately, the tale preserves a complicated nostalgia for the Norse ancestral religion, while reducing the associations of paganism with evil by deflecting evil onto another, independent mythological race. Contemporary historical and literary evidence of the time corroborates this assessment. We may remember that the sixteenth-century bishop Guðbrandur Porláksson (1541-1627) famously voices his frustration in Ein ný sálmabók (A New Hymnal, 1589) over rural Icelanders who enjoy the songs and stories of trolls and pagandom, ${ }^{36}$ and Arngrímur Jónsson's Crymogæa (1609) codifies the view of the Old Norse world as a golden age. ${ }^{37}$ "Gullbrá og Skeggi í Hvammi" contributes to this larger context of cultural memory by reconstituting the male Christian-female pagan opposition. In doing so, the cultural memory reflected by the tale paints a favourable picture of both strong women characters and paganism, while likewise maintaining the integrity of early Christianity in Iceland.

\section{Cases of Witchcraft, Male or Female?}

Female magic users were not limited to mythological figures like the trollish Gullbrá in Icelandic folktales. Sorcerers (male galdramenn and female galdrakerlingar or galdranornir) constitute a vibrant part of the folk record. Even more so than in the story of Gullbrá and Auður, tales of Icelandic magic users often share a connection to historical figures and events. At times these tales make obvious use of typical folk motifs, but sometimes one gets the sense that stories simply report local suspicions of a certain person's magical ability. The role of these tales in Iceland's cultural memory is particularly illuminating on the question of gender and Christianity, but not in ways that might be expected. While Iceland did indeed suffer from the same wave of witchcraft persecutions as other areas of Scandinavia and Europe in the seventeenth century, cases of witchcraft were comparatively few. ${ }^{38}$ Only 120 cases were brought, all of them in the seventeenth century, resulting in only twenty-two defendants being burned for the crime, ${ }^{39}$ while others received less severe punishments or were

36 Margrét Eggertsdóttir, "From Reformation to Enlightenment," 190; Driscoll, Unwashed Children, 14 , for discussions of this sentiment.

37 See also Jakob Benediktsson for a deeper discussion of Arngrímur's motivations for writing his polemics in Arngrímur Jónsson and His Works (Copenhagen: Ejnar Munksgaard, 1957), 32-39.

38 Ólafur Davíðsson, Galdur og Galdramál á Íslandi, ed. Einar Arnórsson, Sögurit 20 (Reykjavík: Sögufélagið, 1940-43), and Ólína Porvarðardóttir, Brennuöldin: galdur og galdratrú í málskjölum og munnmælum (Reykjavík: Háskólaútgáfan, 2000), present the most comprehensive accounts of the witch trials in Iceland. The clearest discussion in English is Hastrup, "Iceland," 383-401. For a recent and comprehensive study of witchcraft in medieval Nordic world, see Stephen A. Mitchell, Witchcraft and Magic in the Nordic Middle Ages (Philadelphia: University of Pennsylvania Press, 2011).

39 Hastrup, "Iceland," 386 
acquitted. ${ }^{40}$ Also unlike Europe, Icelandic prosecution of witches focused primarily on men. Of the 120 recorded cases of witchcraft in Iceland, only ten were brought against women, and of the twenty-two defendants burned, only one was a women (a second was smothered). ${ }^{41}$ These numbers starkly contrast with the results of the witch-hunt craze in Europe, where the total number of cases, and specifically cases against women, was considerably higher. Modest assessments count roughly 50,000 victims, and in most European countries, women were considerably more likely (4 to 1 ) to be accused and executed for witchcraft. ${ }^{42}$ Cases in Europe tended to reflect the sentiments of the late fifteenth-century production Malleus Maleficarum (The Hammer of Witches), in which women were viewed as the morally weaker of the two sexes and therefore more susceptible to temptation by the Devil. Certain regions, however, defied the typical expectation of predominantly women victims of execution. Burgundy (52\% male), Estonia (60\% male), Normandy (73\% male), and Iceland (92\% male) all prosecuted more male than female witches. ${ }^{43}$ Lara Apps and Andrew Gow argue, in fact, that cases of male witches in early modern Europe have been largely ignored. ${ }^{44}$ The overwhelming number of male defendants in Iceland, however, suggests an intrinsic expectation that men, rather than women, practised witchcraft.

It remains to be seen why places such as Normandy, Estonia and Iceland so drastically contradict typical tendencies to accuse women of witchcraft. The anomaly is especially perplexing in Iceland, since, as Helga Kress has recently argued, it is primarily women who practise sorcery in medieval Icelandic sources. Those few men who engaged in witchcraft, says Kress, maintained a close proximity with the female gender: either they owed their magical ability to a more experienced female magic user (typically a family member) or they themselves suffered a kind of feminization by using magic. ${ }^{45}$ In his recent study of magic in the Nordic Middle Ages, Stephen Mitchell

40 Michael Fell, And Though this World with Devils Filled: A Story of Suffering, American University Studies, Series 7: Theology and Religion 236 (New York: Lang, 2007), 15. See also the introduction to Jón Magnússon, Píslarsaga séra Jóns Magnússonar, ed. Matthías Viðar Sæmundsson (Reykjavík: Mál og Menning, 2001).

4 I Hastrup, "Iceland," 386.

42 Alan Charles Kors and Edward Peters, "Introduction: The Problem of European Witchcraft," in Witchcraft in Europe 400-1700: A Documentary History, 2nd ed. (Philadelphia: University of Pennsylvania Press, 2001), 1-40 at 17. This ratio has raised much scholarly debate. See Elspeth Whitney, "The Witch 'She'/The Historian 'He': Gender and the Historiography of the European Witch-Hunts," Journal of Women's History 7 (1995): 77-101; Lara Apps and Andrew Gow, Male Witches in Early Modern Europe (Manchester: Manchester University Press, 2003).

43 Apps and Gow, Male Witches, 45.

44 Apps and Gow, Male Witches, 2-3.

45 Helga Kressm “'óparfar unnustur áttu,' Um samband fjölkynngi, kvennafars og karlmennsku í Íslendingasögum,” in Galdramenn: Galdrar og samfélag á miðöldum, ed. Torfi H. Tulinius (Reykjavík: Hugvísindastofnun Háskóla Íslands, 2008), 21-49, especially 22. Compare FrançoisXavier Dillmann's argument that magic users in Old Norse narratives are evenly numbered between male and female: Les Magiciens dans l'Islande ancienne (Uppsala: Kungl. Gustav Adolfs Akademien 
corroborates the notion of the Nordic medieval feminization of magic: "one also senses an important and meaningful opposition between that which is 'manly' or virtuous ..., on the one hand, and magic, on the other." ${ }^{46}$ In contrast, Gunnar Karlsson and several others suggest that the surprising dearth of female witches in the country results first from the sociological status of women in seventeenth-century Iceland and second from the uniquely Icelandic perspective on what constituted magic use. ${ }^{47}$ In comparison with the European descriptions of witchcraft, Icelandic law defined witchcraft as having a much stronger element of literacy. Sorcerers were said to study magic books and to carve runes. Since women were largely illiterate, the argument goes, it was impossible for them to qualify as magic users. Fell adds that since women were typically more closely bound to the home, they would rarely have had the opportunity to go into the wilderness or live on the outskirts of society for the purposes of conducting witchcraft. ${ }^{48}$

This sociological assessment goes a long way to explaining why Icelandic accusations of witchcraft largely ignored women, but the scarcity of female witches in the historical record may also be reflected by the folk tradition, where primarily male sorcerers seem to have prevailed as well. While, as Kress observes, Iceland certainly enjoyed a legacy of strong supernatural female beings in the figures of the norn, the Valkyrie, and the volva from pagan times, the idea of female magic users seems not to have survived the Christianization and Reformation processes. It is true, as Ellison points out, that several women magic users appear in the later folk record, ${ }^{49}$ but these female figures invert the medieval trend and often display some key proximity to other, male, magic users. As indicated by the discussion below, this proximity occurs in many cases by way of some family connection: a husband or father has taught magic to his wife or daughter. At other times, the proximity is more simply a morphological one. The first post-Christianization sorcerers were men, beginning in the twelfth-century tales of Sæmundur fróði. ${ }^{50}$ From then on, folk tradition closely follows the Sæmundur tales

för Svensk Folkkultur, 2006), 157. Note Jóhanna Katrín Friðriksdóttir's comments in “Women's Weapons: A Re-Evaluation of Magic in the Íslendingasögur," Scandinavian Studies 81 (2009), n. 1, and Images of Women, 123, which make it clear that the strength and numbers of women magic users were greater than men.

46 Mitchell, Witchcraft, 190.

47 See Gunnar Karlsson, Iceland's 1100 Years, 146; Hastrup, "Iceland," 227-28; Fell's “Introduction" in And Though this World, n. 36; Ruth C. Ellison, "The Kirkjuból Affair: A Seventeenth-Century Icelandic Witchcraft Case Analyzed," Seventeenth Century 8 (1993): 220; Shaun F. D Hughes, "The Re-emergence of Women's Voices in Icelandic Literature, 1500-1800," in Cold Counsel: Women in Old Norse Literature and Mythology, ed. Sarah M. Anderson and Karen Swenson (New York: Routledge, 2002), 91-128.

48 Fell, "Introduction," And Though this World, n. 36.

49 Ellison, "The Kirkjuból Affair," 219.

50 Terry Gunnell has done a thorough review of the folk tradition of Sæmundur fróði: see "The Return of Sæmundur: Origins and Analogues," in Pjóðlif og Pjóðtrú: Ritgerðir Helgaðar Jóni Hnefli Aðalsteinssyni, ed. Jón Jónsson, Terry Gunnell, Valdimar Tr. Hafstein, and Ögmundur Helgason (Reykjavík: bjóðsaga, 1998), 87-111. See also Jón Hnefill Aðalsteinsson, "Sæmundr fróði: 
either by leaving out female magic users altogether or by associating them in some way with that tradition. Additionally, magic users in the Sæmundur tradition tend, somewhat strangely, to use their abilities for the good of Christian people; most of them were in fact said to be reverends in the Church. The result is that we do not observe the typical European-style female witch in Icelandic folktales. In terms of tradition, it may not have been folkloristically feasible for women to be witches in the European sense. The witch-hunt craze in the seventeenth century simply had no folk identity upon which to graft itself. The post-medieval folk tradition of Icelandic magicians was male and pro-Christian, though indeed on the fringe, while the European tradition perceived witches as female and anti-Christian. The two traditions were in competition with one another, and the older, native tradition won out. There was no folkloristic room for the European-style witch to flourish.

This suggestion finds some confirmation in the tale conspicuously titled "Nornin á Saxlandi," 51 or "The Witch of Germany," one of the few references to a European-style female witch in Icelandic folklore. In the tale, Sæmundur, the prototypical Icelandic sorcerer, has apparently agreed to marry the eponymous German witch, but only so that he can play her for a fool. When the witch realizes that she has been insulted, she sends Sæmundur a cursed $\operatorname{cask}^{52}$ of ominously red-coloured gold. The tale at this point becomes an opportunity to show that Sæmundur outwits his opponents, and he takes the cask of red gold and throws it into Hekla, a volcano in the south of Iceland. The tale is very clear that Sæmundur would never marry the German witch and that he is the more powerful magic user.

Jón Árnason acquired this tale from the manuscripts of Árni Magnússon, who lists as his informants Björn Porleifsson (1663-1710), who was bishop of Hólar, Captain Magnús Arason (ca. 1684-1728), and Halldór Porbergsson (ca. 1623-1711), all of whom died in the early eighteenth century. This tale very likely then represents a late addition to the Sæmundur tradition, one that developed only after the explosion of witch-hunts in Europe. On the level of folk memory, the tale indicates a distancing of Icelandic belief in magic from European varieties. The German witch represents the malevolent, typically female strain of European magical prowess, stories of which had by that time made their way to Iceland as indicated by the historical records mentioned here. This tale makes an enemy of that type of witchcraft, saying, quite literally, that Icelandic magic, like Sæmundur, will never "marry" it. The prototypical Icelandic magician then engages in and wins contests against the foreign type of witchcraft, and divorces himself from it forever.

A Medieval Master of Magic," Arv 50 (1994): 117-32; and chapter 5 (124-38) for more on the legacy of Sæmundur fróði.

5I JÁ 1:471.

52 The tale refers to a sending, which can aptly be translated as a "gift," but presumably one that is intended to harm rather than acknowledge friendship. In this case it can be considered a subset of the more typical ghost-like sending common in Icelandic lore from the late medieval period, in which a sorcerer sends a spirit to harass the object of his displeasure. 
More will be said of Sæmundur and other magic users in chapter 5, below, but this brief foray into magicians in Iceland should be enough to indicate that, at least generally speaking, the prevalence of male magicians in Iceland appears to preserve at least the male/Christian half of the gendered spheres discussed at the beginning of this study, but the few tales of female magic users in the later sources articulate a meaningful female sphere as well. Three female magicians are of special interest. StraumfjarðarHalla (Halla of Straumfjörður), is said to be one of two sisters of Sæmundur fróði, the most famous of all Icelandic sorcerers, though, according to Jón Árnason, she lived several hundred years after Sæmundur. ${ }^{53}$ Halla's magical prowess certainly echoes that of Sæmundur, and she appears, like him, to use magic with benevolent intent. Further, many motifs corresponding to those of other magician tales appear: haymaking, anxiety over the state of the soul at her death, and assisting those in need while attacking the greedy. ${ }^{54}$ These motifs suggest no specific gender, but the tale entitled "Ljósmóðurstörf Höllu" (Halla as Midwife) ${ }^{55}$ bears particular poignancy for the role of magical women in post-Reformation Iceland. The tale states that Halla, a skilled midwife, was called upon to assist a woman in labour. When the labour pains get too great and the woman begins to scream out in pain, her husband chastises her, remarking that it cannot be as bad as she is making out. Hearing the husband's ignorant remarks, Halla tells him to try it himself and see how he likes it. At once, the husband begins wailing with pain and the wife's pains cease, and so it continues until the baby is nearly born, when the pain returns to the wife for the final moments of birth. The tale concludes with Halla remarking that she was able to have the husband bear the pain of labour but not the baby itself.

Halla's actions bring her closer to what Simpson refers to as a "white witch," or someone who uses charms to effect good, often times as a healer or midwife. ${ }^{56}$ In its patently Icelandic social and folkloristic context, however, the tale also presents Halla as one who has the ability to usurp authority from the patriarchal figure (in his own house, no less!) and hand it over to the matriarch. In this way the tale confirms the female sphere as private, intimate, based in the home, and of course childbirth is entirely in the female sphere. The husband's remarks infringe upon the female sphere in a decidedly

53 JÁ 1:494, n. 1. Halla lived in the fifteenth century, in Straumfjörður in the west of the country. Also of historical interest, as Simpson has stated, are the famous gifts that Halla purportedly gave to Alftanes church: fishing rights for a particular area and a magic cooking pot (Simpson, Legends, 96).

54 For more on the connections between Halla and Sæmunudur, see Jón Hnefill Aðalsteinsson, "Six Icelandic Magicians after the Time of Sæmundur Fróði," trans. by Terry Gunnell, Arv 52 (1996): 49-50.

55 JÁ 3:539. It is worth noting that Jón Árnason rejected this tale from his original collection. It was not included until the 1954-1961 edition, along with other rejected tales. One can only speculate as to why it was initially rejected. It was collected by Brynjólfur Jónsson (1838-1914) of MinnaNúpi, who regularly contributed to Jón Árnason's first edition but also had several tales rejected. See also Brynjólfur Jónsson frá Minni-Núpi, Tillag til albýðlegra fornfræði, ed. Guðni Jónsson (Reykjavík: Menningar- og fræðslusamband alpýðu, 1953).

56 Jacqueline Simpson, “Witches and Witchbusters," Folklore 107 (1996): 9. 
male manner, reflecting what amounts to a public display of strength and authority. When Halla forces him to suffer the pains of labour, she not only preserves the female sphere, she also threatens to undermine the husband's authority in the public sphere. Should anyone in the male sphere see him, he would lose face. Finally, the last moments of the tale confirm the ultimate primacy of the female sphere, for only women can know the experience of childbirth. Only in the female sphere does such intimacy between mother and child exist.

Other tales of female magic users are much more mixed in their sympathy. Margrét Pórðardóttir (d. 1726), known as Galdra-Manga (Sorceress-Margrét), is thought to be the daughter of Pórður Guðbrandsson, who was burned to death for sorcery at Trékyllisvík in $1654 .{ }^{57}$ She lived during the height of the witch-hunt period and is probably the most famous female witch in Iceland. Accounts of her in Jón Árnason's collection, ${ }^{58}$ much more so that those of Halla, convey what appear to be local suspicions of Margrét's magical prowess and vindictiveness, rather than morphologically significant motifs. Like Halla, Galdra-Manga is associated with a male magic user, though one less prevalent than Sæmundur. Galdra-Manga apparently acquired her magical ability from her father, Porður. As such, she again inverts the medieval phenomenon of male magic users acquiring their ability from a female family member. ${ }^{59}$ She was twice convicted and tried for witchcraft, once in 1656, again in 1660 , and was acquitted both times.

Interestingly, according to tradition, Galdra-Manga is said to have used her magical prowess seemingly to advance gendered ends. According to the tales, she used magic to seduce married men, specifically priests, and then killed their wives. ${ }^{60}$ In the 1660 suit against her, however, her husband, Reverend Tómas Pórðarson of Staður on Snæfellsnes, served rather effectively as her advocate, though of course the cynic would say that he was under her "spell" and bound to do so. After the last trial, sources are divided on what happened. Some say she lived happily with Tómas for some years, while others say that the disgrace of the trial divided the couple and that Tómas suffered financially and personally at the end of his life. By conveying the notion that Galdra-Manga uses magic to seduce her lovers, tales of her exploits distort the female social sphere. While she seeks a private, intimate life based in the home, she also disrupts the alreadyestablished (male and female) spheres of her lovers and their wives. She strangely favours the Church, but once again in the distorted manner of seducing its reverends. Tales of her exploits convey, then, a poor example of the female sphere, but an example nonetheless.

57 JÁ 1:517.

58 JÁ 1:517-20. Jón Árnason took these accounts from the manuscripts of Gísli Konráðsson (1787-1877) and Rev. Benedikts Pórðarson (1800-1882).

59 As noted by Helga Kress, in "Óparfar unnustur áttu," 22; see my comments above.

60 She also seems to help other adulterous women escape discovery by their husbands, as in the tale "Hrakningar Möngu" (JÁ 1:517-18). 
Finally, like the tales of Galdra-Manga, those about Stokkseyrar-Dísa, that is Pórdís Markúsdóttir from Stokkseyri, ${ }^{61}$ report more anecdotal information than discernable folk motifs. Dísa's infamy often seems to derive from her general bad nature and mischievousness, which is only sometimes associated with magic. She more effectively distinguishes herself as a drunkard and a thief, as her evil intentions, mischievousness, and poor social conduct prompt her ejection from society more than her use of magic. In some ways, it must be admitted, Dísa reflects a more typical European witch. She seems to have some skill with magic, she lives on the outskirts of society, and she does harm to others for her own gain. Yet in one way she fails in the end to meet European expectations. Female witches in seventeenth- to nineteenth-century Europe tend to be older, beyond childbearing age, and in fact sometimes associated with physical symptoms of menopausal woman. For this reason, scholars have often discussed whether and how European and American witches play havoc with gender roles, as they no longer are able to act as sexual partner or mother. ${ }^{62}$ Not only does Dísa contradict this European trend, she does so while on her way to distorting the female sphere. In one instance she is said to have borne two children, twins, but to have starved them to death, possibly so she could raise them again as zombie-like sendingar (discussed below). Like Galdra-Manga, Dísa offers a grotesque image of the female sphere, particularly in regards to her family.

\section{Gender Spheres and the Elf Woman's Conversion}

Whereas magician tales and witchcraft leave little room for fringe or opposing female voices in Christendom, other tale types freely allow them. It was observed earlier how Gullbrá the troll-woman represents a significant female voice opposing Christianity though not one directly associated with paganism. Icelandic elf tales also regularly present female voices that begin on the fringe of Christendom, but, unlike female trolls, elfish voices ${ }^{63}$ tend to seek reconciliation of some kind with the male, Christian sphere. The story of the elf woman's conversion has its peculiarities but, for better or worse, it fits somewhere into this trend. The tale bears the marks of several familiar motifs and generally falls into a fairly significant group of tales about elves seeking companionship with humans, which Jón Árnason entitled “Huldufólk leitar lags við

61 JÁ 1:566-68.

62 See, for example, Simpson, "Witches," 7-9; Carol Karlsen, The Devil in the Shape of a Woman: Witchcraft in Colonial New England (New York: Norton, 1987), 111-19; Francisco Bethencourt, "Portugal: A Scrupulous Inquisition," in Early Modern European Witchcraft: Centres and Peripheries, ed. Bengt Ankarloo and Gustav Henningsen (Oxford: Clarendon, 1990), 415; Christina Larner, Enemies of God: The Witch-Hunt in Scotland (London: Chatto \& Windus, 1981); Christina Larner, Witchcraft and Religion: The Politics of Popular Belief (Oxford: Blackwell, 1984).

63 I do not mean to imply anything necessarily about elves as a mythological species but rather about a certain voice that assumes the identity of elfishness in this and other tales. See Terry Gunnell's study on the dangers of mis-categorizing elves in the Germanic and Scandinavian traditions: "How Elvish Were the Álfar?", in Constructing Nations, Reconstructing Myths: Essays in Honour of T. A. Shippey, ed. Andrew Wawn (Turnhout: Brepols, 2007), 111-30. 
mennskar manneskjur" (The hidden people seek companionship with human people) ${ }^{64}$ Many elements of these narratives cohere with an Irish and Welsh tradition, but the Icelandic versions nearly always qualify as having experienced a significant oikotypal shift. Even those stories, such as the famous "Kötludraumur," which enjoyed popularity in the rímur or ballad genres, display indications of an oikotype. In the Icelandic tales, events take place in specific Icelandic towns to specific (often historical) individuals, and the logic of the respective tales tends to be consistent. All these factors localize such tales within an Icelandic context and thus make them useful to our study of cultural memory.

As a folk figure, Valbjörg fits the typical paradigm that one might expect from narratives associated with fairies and a fairy world: An elf or fairy woman lures a man from the human world into marriage and life in the fairy world (F302 and F302.1), ${ }^{65}$ while a taboo prevents the man from rejoining the "outside world" where his family resides. Valbjörg's love affair with Sigurður also confirms Richard Firth Green's observation that a "characteristic of female, as opposed to male, fairy lovers ... is that they must be sought at the untamed edges of the human lifeworld." 66 The conversion motif likewise matches V331.8 (Fairy Converts to Christianity), and several instances exist in Irish and Scandinavian lore in which a fairy, a giant, or a troll seeks either baptism or burial in a Christian churchyard. ${ }^{67}$ The Valbjörg narrative, however, adds something to these motifs and other stories, specifically with respect to the notion that Valbjörg's elf-hood can be "cured." The Irish tales in particular tend to emphasize religious conversion through reasoning rather than exorcism. The Irish motif F382 (Exorcizing Fairies) describes fairies that disappear when a Christian ritual takes place, ${ }^{68}$ but this generally results in the fairy's demise, or at least its profound discomfort, much as Valbjörg's initial response when she hears the name of God. In these motifs, elf-hood remains a part of the figure's genetic makeup, as it were, regardless of whether a conversion or exorcism takes place. In the Icelandic variety, the actions of the priest Eiríkur change Valbjörg's nature-literally, the tale says, her "konukindina" (womanhood). ${ }^{69}$

64 JÁ 1:58-100.

65 These designations accord with Stith Thompson's Motif-index of Folk-Literature: A Classification of Narrative Elements in Folktales, Ballads, Myths, Fables, Mediaeval Romances, Exempla, Fabliaux, Jest-Books, and Local Legends, rev. ed., 6 vols. (Bloomington: Indiana University Press, 1955-58).

66 Green, Elf Queens, 100.

67 See, e.g., Tom Peete Cross, Motif-Index of Irish Literature (Bloomington: Indiana University Press, 1952): F251.8 (Fairy Professes Faith in Christianity); F389.6 (Abduction of Christianized Fairy Woman by Fairies Prevented by Saint); F394.1 (Mortal Advises Fairy); F531.5.8 (Giants and Christians); F531.5.8.3 (Giant Christianized); and F.268.1 (Burial Service for Fairy Queen Is Held at Night in Christian Church).

68 Katharine M. Briggs, A Dictionary of British Folk-Tales in the English Language, 4 vols. (Bloomington: Indiana University Press, 1970-71), 1B:191.

69 JÁ 1:99. 
Despite these morphological indications, we do not have a thick enough corpus of folkloristic evidence to speculate much on the psychological implications of the tale, ${ }^{70}$ but it may be possible nevertheless to hazard an assessment of Valbjörg's function as a convert to Christianity in light of adjacent narrative traditions, either those about fairies or those about conversion. ${ }^{71}$ Green has observed that a few authors of medieval romances depict fairies living as integrated members of Christendom, ${ }^{72}$ some even swearing oaths by the Virgin Mary and participating in mass. ${ }^{73}$ Green contextualizes these instances of fairies in Christendom within a larger tension between clerical and popular beliefs about fairies. According to Green, these "Christian" fairies represent an example of "cultural compromise formation," ${ }^{4}$ by which "vernacular culture ... might make remarkable efforts to adjust its beliefs to the orthodoxies of the church." ${ }^{75}$ A similar type of compromise seems quite in line with the present discussion of the Valbjörg narrative, so that we may add to the narrative mechanisms observed in chapter 1 , of pejoration and adjacency pairs. In the Valbjörg narratives, the mechanism of cultural compromise formation works to draw the heterodox beliefs in elves and elfish power, beauty, and grandeur in line with orthodox views of Icelandic Christianity, such that it is not only Valbjörg who converts to Christianity but also-and perhaps even more importantly-narratives about elves that have also converted to Christianity.

Valbjörg, like Gullbrá, reflects a powerful female figure in opposition to Christianity, while Sigurður represents the brave, civilized Christian male. Before her conversion, at least, their relationship appears to corroborate a version of the Christian male-pagan female opposition. She effectively attempts to create the ideal female sphere: their preconversion life is domestic, certainly private, and opposed to Christian conversion, but it has been relegated to the periphery, out of sight of civilization. The relegation confirms Grønlie's suspicion that, "as Christianity strengthens its hold on society, what remains of age-old pagan practices is banished to the periphery-they become the domain of old women, widows, foster-mothers, and others on the outskirts of the male community."76

70 Other Icelandic tales of elves, though not a part of the same corpus, hit near to the gender trends observed in the Valbjörg narrative. For instance, the Icelandic folk record supports the common international tale that claims the "hidden people" originate from Eve's attempt to hide from God her unwashed children, which leans toward a matriarchal view of elfish legacy ("Huldumannagenesis," JÁ 1:7). This is a common tale in Borgarfjörður, but the tale is also prevalent in Rogaland, Norway. See Reimund Kvideland and Henning K. Sehmsdorf, Scandinavian Folk Belief and Legend, The Nordic Series 15 (Minneapolis: University of Minnesota Press, 1988), 205-6.

7I Female elves regularly make appeals to the Christian church for assistance or salvation (especially ML 5050: Fairies' Hope for Christian Salvation), appeals which tend to be associated specifically with their social or biological roles as women.

72 Green, Elf Queens, 62.

73 Green, Elf Queens, 69.

74 Green, Elf Queens, 69. This idea derives from Ginzburg's Ecstasies, 11.

75 Green, Elf Queens, 2.

76 Grønlie, “Neither Male nor Female," 303. 
When Valbjörg turns the corner and recovers to become, to all appearances, an "elf-free" Christian woman, the tale breaks the opposition of male Christian and female pagan and reconciles the two spheres. Thus joined, Valbjörg and Sigurður then have the opportunity to contribute to the newly reconciled spheres by way of their children. In plain terms, "converting" Valbjörg moves subsequent generations away from her peripheral spiritual position and toward the established Christian belief system. In fact, we are told that Sæmundur Magnússon Hólm (ca. 1749-1821), a prominent priest near Helgafell, was descended from Valbjörg, though he would not often speak of his elfish heritage.

Finally, Valbjörg's proximity to the Old Norse pagan religion remains quite ambiguous. Her name offers the only clues to the puzzle: The reader may recall that Valbjörg says of herself that she is sometimes called "Vandráð," a name of unclear origin but one that might reasonably be translated as "difficult choice." Within the folktale itself, this appellation may be a reference to Sigurður's difficult decision to become Valbjörg's (Vandráð's) lover or to die like the other men captured by her, yet it might also be a reference to Valbjörg's own difficult choice to remain an elf or to convert to Christianity-if, that is, Valbjörg had any choice at all in the matter. More intriguing, Vandrád is also the root of the somewhat uncommon Old Norse male version of the name, Vandráður, which appears in the Icelandic conversion narrative, Kristni Saga. According to Kristni Saga, Vandráður (along with his brothers) prosecuted the missionary Stefnir-who was a relative of theirs-for being Christian, since a recently passed law had dictated that taking the Christian religion was a shame upon one's family and thus it was the responsibility of the family to prosecute the case against any Christian. ${ }^{78}$ Stefnir is summarily convicted and shipped off to Norway. In the story of Valbjörg (Vandráð) the elf, the tables have turned in more ways than one: the opponent of Christianity has gone from male to female (Vandráður to Vandráð); the woman is converted to Christianity rather than prosecuting someone else for being Christian; and she is brought into a family rather than being prosecuted and cast out by her family. The gender spheres in the two stories are almost completely reversed.

Nevertheless, the Valbjörg narrative never overtly states her "religion," unless elfhood could be called a religion. In the same way that "Gullbrá and Skeggi in Hvammur" creates a new sphere-the troll sphere, which has not only an anti-Christian identity but also an evil, dangerous one-the story of Valbjörg seems to create another sphere, set apart from the expectations of the traditional male and female spheres of Old Norse texts. Unlike Skeggi, the elf Valbjörg does not reflect an overtly Norse pagan figure, but nor does the tale wholly demonize her, as was the case with Gullbrá, despite the fact that Valbjörg has been doing rather a lot of killing. Valbjörg stands rather as a representative of peripheral culture and beliefs that fall outside of normal Christian doctrine, having only a vague connection to ancient religion, but one that enables reconciliation

77 Richard Cleasby and Gudbrand Vigfusson, Icelandic-English Dictionary (Oxford: Clarendon, 1874), s.v. vand-.

78 Kristni saga, in Biskupa Sögur I, ed. Sigurgeir Steingrímsson, Ólafur Halldórsson, and Peter Foote, Íslenzk Fornrit 15 (Reykjavík: Hið Íslenzka Fornritafélag, 2003), 17. 
nonetheless. This new sphere, which we may call simply the "elf sphere" in opposition to the "troll sphere," again represents a slice of cultural memory that stands outside Christianity, but the elf sphere creates a venue for reconciliation between orthodoxy and heterodoxy instead of the hostility observed in Gullbrá's troll sphere. Rather than reconciliation of Christianity and ancestral paganism, which we saw in the tale about Gullbrá and Skeggi, Valbjörg's conversion marks the redemptive possibilities between peripheral beliefs and the "male" Christian belief system of the priest Eiríkur and Sigurður's family. To include marriage and childbearing as aspects of that redemption serves not to highlight the confrontation between Christianity and a peripheral mythological figure but rather to draw her out into the accepted, albeit unorthodox Christian culture. The tale is perhaps no less misogynistic for all this-the female sphere is certainly redefined by the male-yet the cultural memory embedded within the story runs deeper: the gender spheres transcend gender, only to take on the dynamic of religious belief within a complex cultural memory struggling to reconcile heterodoxy with orthodoxy. In a sense, then, all heterodoxy becomes female in contradistinction to the orthodox male, and the normative male seeks to reconcile the female to himself.

\section{Final Thoughts:The Elf Woman's Conversion}

Margaret Cormack has shown that post-Reformation folktales about Catholic saints conflict with pre-Reformation sources. Concerning "associations between places and objects with supernatural power," she argues that "accounts for place-names, power, or other associations have been subject to more or less drastic revision or reinvention."79 Cormack's evidence is compelling, and my aim in this chapter is not to contradict her broader conclusions concerning the historical value of post-Reformation folktales. Even those that may not accurately corroborate historical evidence still have the capacity to unlock meaningful evidence of the culture from which they come. One must nevertheless proceed with care. Approaching folktales in search of cultural memory helps illuminate important issues in a culture, but to achieve a reliable correspondence between a particular tale (or group of tales) and a culture's memory, we must have confidence in the tale's connection to a particular cultural context. ${ }^{80}$ It is for this reason that the Icelandic folktales of Jón Árnason's collection hold particular value for the study of

79 Margaret Cormack, "Catholic Saints in Lutheran Legend: Post-Reformation Ecclesiastical Folklore in Iceland," Scripta Islandica 59 (2008): 47-71 at 67.

80 Lauri Honko, for instance, sought a "thick corpus" and organic variation, meaning that enough variants of the same tale would indicate a living oral tradition. See his "Thick Corpus and Organic Variation." This type of variation is difficult to reproduce in tales recorded in written archives (such as the Jón Árnason collection), but Jyrki Pöysä offers some help in this regard, suggesting that variation "in archived anecdotes can be divided into at least the following sub-categories: agent changes, changes in the level of abstraction (of agents and milieu), changes in the narrative's social outlook, and changes in the degree of personal experience." See Jyrki Pöysä, "Variation in Archived Anecdotes," 580. 
cultural memory. Because of the diligence of their editors and collectors, we now benefit from quite specific knowledge about the origins of these tales, including where, when, and from whom they were collected. This wealth of information, taken alongside the large body of manuscript traditions in Iceland, helps to solidify our understanding of the social context for these Icelandic folktales. Of course, we must not confuse how our conclusions might be applied. The tales studied here reveal something about the cultural memory of a post-Reformation Iceland, and we must be careful not to step too far outside that purview. Nevertheless, while it may be too hasty to suggest that these tales reflect an ancestral pagan religion, it would not be too hasty, I think, to suggest that within the cultural memory of these tales, they do. The Auður and Skeggi of the Gullbrá tale are not the same Auður and Skeggi of ninth-century Iceland, but they do contribute to a postReformation cultural memory (accurate or not) of those figures. Likewise, the magic users of post-Reformation tales differ significantly from stories found in early medieval sources, but those differences reflect valuable information about the development of belief systems in Iceland from earlier to later sources. Finally, elfish figures such as Valbjörg must obviously not be confused with pre-Christian notions of, for instance, landvættir (land spirits), but she does represent a lingering sympathy for supernatural beings who fall outside Christian acceptance. In all these tales, it is clear that changes in the cultural memory have occurred since the medieval period. The question now must become what do these changes indicate about Icelandic cultural memory? In this chapter I have tried to answer that question specifically regarding the roles and functions of female characters, but as this examination proceeds, the same question will be asked of other key elements of belief as well.

The tales discussed here serve the purpose of reconciling, and perhaps rationalizing, peripheral belief systems with the more orthodox Christian beliefs of their day. All of these tales nonetheless also suggest an unwillingness to dispense with these peripheral and "ancient" features within Iceland's cultural memory, even if, in some cases, attempts are made to incorporate those peripheries into the centre, as in the story of the elf woman's conversion, through what must be considered a typical masculine appropriation of the female sphere. The addition of the "troll sphere," as in the narrative about Gullbrá, allows both the female authority figure of Auður and the pagan authority figure of Skeggi to retain their nobility. These tales employ an earlier literary topos to achieve their goal, which is perhaps not surprising given Iceland's high esteem for its "ancient images," as Hastrup puts it, ${ }^{81}$ but the usage of these topoi represents an appeal to internal context. The external context, of Reformation theology and the post-medieval worldview, influences how that internal context must be understood. The later folktales manipulate those spheres to achieve their reconciliation between fringe beliefs and more orthodox views. In terms of Iceland's religious and literary history, this assessment suggests that it was not only prominent church figures like Guðbrandur Porláksson who sought reconciliation between popular oral tradition and

8 I Hastrup, Nature and Policy, 190. 
the Church: the "centre" was reaching outward to the periphery, as it were. From the opposite direction, the "peripheral," orally transmitted folklore also reached inward toward the centre, attempting to connect with orthodox beliefs.

Concerning the role and function of the female folk figure in post-Reformation folktales, we find that she is a vibrant, vitally functional, and dynamic figure, every bit as intriguing as her medieval predecessor. The presence of strong female characters suggests that, at least in the folk literature, the long development of Christianity in Iceland has not resulted in the diminution of female figures within Iceland's cultural memory. Though sometimes mixed in their opposition or support for Christianity, the female folk figures in these tales were integral in shaping the cultural memory of Icelandic Christianity. In other words, as Christianity developed throughout the country's history, the female folk figure was not merely passively influenced by the "radical remapping of gender," to borrow a phrase from Carol Clover; ${ }^{82}$ the female folk figure was also herself a vehicle for the convergence of ancestral images and the Christianity that so affected her.

82 Carol Clover, "Regardless of Sex: Men, Women, and Power in Early Northern Europe," Speculum 68 (1993): 385. 


\title{
Chapter 3
}

\section{THE FYLGJUR OF ICELAND: ATTENDANT SPIRITS AND A DISTORTED SENSE OF GUARDIANSHIP*}

\author{
The Móri of Sel (or Porgarður)'
}

At a farm near the river Elliðá [near Reykjavík] there lived a certain couple, and with them lived a workman named Porgarður. The gossip was that the woman was having an affair with the man under her husband's nose. Also, it was considered a certain thing that the farmer had to bow deeper before the woman than the workman because the farmer went often to do trivial tasks, and was outside during bad weather when Porgarður stayed home.

It was the farmer's habit to look after his livestock himself in the winter whenever the weather was bad. One winter night in a snowstorm the farmer didn't come home, neither that night nor the night after. He had gone to check on the sheep the previous morning and had intended to look after them during the day. The following morning people went looking for him, and he was found by the river Elliðá with what appeared to be a fatal wound inflicted by human hand. Porgarður was suspected because of the rumours about him and the farmer's wife, and the case was brought against him. It was in all likelihood porgarður who carried out the crime even though he vigorously denied it. Regardless, he was convicted of it, and it was decided that he would either be put to death (some say by hanging) or have to pay a substantial compensation, so he would only be able to save his life with a considerable fee. And so it turned out here as is to be expected, as most people choose to prolong their life, and for this reason Porgarður wanted to save his skin for as long as possible.

At that time a famous diplomat named Jón lived at Sel in Seltjarnarnes. Porgarður went to Jón and begged him to help save his life. Jón was at first reluctant to do so, but porgarður was so persistent that finally he acquiesced and decided to pay Porgarður's compensation. Porgarður had even promised to serve Jón and his descendants faithfully and virtuously, working with all his might and for as long as it took. Jón went to the table and began counting out the coins for the compensation, with Porgarður right next to him the whole time. When Jón had been counting for a while, Guðrún, his wife, came into the living room and, seeing the money that Jón had set out on the table, asked what he wanted

\footnotetext{
* An early version of this chapter originally appeared in my article "Icelandic Fylgjur Tales and a Possible Old Norse Context."

I Translated from JÁ 1:373-76. This narrative was compiled by Jón Árnason from stories circulated in Álftanes, Seltjarnarnes, and elsewhere in the region of Árnessýsla (in the southwest of Iceland). Valgerður Jónsdóttir (1771-1856) and Hólmfríður Porvaldsdóttir (1812-1876) are also listed as sources. Special thanks to Shaun F. D. Hughes for his vital help with several difficult aspects of this translation.
} 
with all the money. Jón told her what it was for, but she told him not to go through with such foolishness for a worthless man like Porgarður, for whom the only thing he had going for him was that he should not be spared from hanging. At that moment the housewife took up the corner of her apron in one hand, walked to the table and swept all of the money into her apron with her other hand. Jón acquiesced both to her argument and to her sweeping away the money. She said she was taking the money with her, and then she looked at Porgarðar and said, "Let everyone be responsible for their own actions." porgarður replied, "We are not done with each other here, because that is not more than for me to see to it that my fylgja will bid farewell to the two of you and your family in the ninth generation." Then Porgarður was executed for his crimes. There are doubts as to whether it was done here or overseas, ${ }^{2}$ but it is thought to be true that he was hanged in Kópavogur, and he immediately returned from the dead and attacked the couple at Sel, particularly Guðrún, Jón's wife, just as he had promised. Guðrún was beset with both unconsciousness and delirium.

Because this ghost stayed in Sel for a long time, he was called Sels-Móri, but he was also called "Porgarður" now and then, and he kept that name as well, since the man had been so called. The couple at Sel had a daughter who was named Porgerður. Halldor Bjarnason, the noteworthy farmer in Skildinganes, married her, and together they inherited both the wealth of Jón and Guðrun and the family ghost [ættarfylgja], called porgarður or Sels-Móri. A few short tales about him still circulated, both in Halldór's and Porgerður's time and likewise while Bjarni, their son, was living in Sviðholt. This Bjarni was a very energetic man. He was probably one of the members of the legal court whom the law speaker Magnús Ólafsson appointed later to the Alping of Öxará, 1798, and Bjarni lived then at Hlið at Álftanes. After that Bjarni became the school manager when the school was moved to Bessastaðir, but he still lived for a long time in Sviðholt, and was nominated district leader at Álftanes. Even though Móri did little for himself at that time, neither in Skildinganes with Halldór nor in Sviðholt while Bjarni lived there, he was likely still there for a long time and afterward while Bjarni's descendants lived there. He was thus regularly called Sviðholt's ghost, but very often he was still associated with the name porgarður.

Bjarni of Sviðholt had several promising children, who were well-known and thought rather bright, and there seems little sign that Móri harassed these children or their descendants who are living now. Another daughter of Bjarni, who was named Puríður, married Benedikt Björnsson, a student from Hitardalur, who has long been the parson in Fagranes. She was an intelligent woman, but she suffered the misfortune that she was halfdemented and sometimes completely crazy. Because of this she split from her husband, and Ragnheiður, her sister, took her in. She was the wife of Jón Jónsson, the school teacher at Bessastaðir, and later she was the first wife of Bjarni Gunnlaugsson, the headmaster at Reykjavík. It seems that Puríður died while in her sister's care. Among the things Puríður

2 During this time in Iceland, capital punishments were often carried out in Denmark. Special thanks to Shaun F. D. Hughes for directing me to this point. 
is reported to have done during her delirious fits, is to have said, "Dear Sister, it is a viper that stings me," but others testify that she would say, "It is always Ingibjörg that stings me in the heart with a cobbler's needle." People suspected that she was referring to Ingibjörg Jónsdóttir of Álftanes, who lived with Benedikt and Purídur before they separated, and who later became Benedikt's second wife, so that Purídur had there, if you like, a reason for her deliriousness. Puríður's family ghost [ættarfylgja] was held responsible for her madness although it has not manifested itself to any extent in the family since then; still some consider those people overbearing, and not at all in line with the ordinary temperament of people [alpyðuskapur]. I have not heard any stories in which Porgarður harassed the housewife, Ragnheiður Bjarnadóttir, who was mentioned earlier, but there are rumours in Suðurland that he caused the destruction of a mail boat that was lost in 1817 because her first husband sailed with it. He was also the cause of the late Pórður Bjarnason's death, in Sviðholt; it is still said that he had haunted the children of Ragnheiður, especially Björn, the principal, and some have seemed to have been aware that this was the case.

It should be mentioned here that Bjarni Halldórsson in Sviðholt had a sister then who was named Jórunn. She was a very haughty and ornate woman. It is said that a certain man at Álftanes proposed to her, but she thought the situation beneath her and refused him. Then it is said that he had vowed, for his part, that despite this he would cling to her family line, even though he was prevented from attaching himself to her in the fashion he wanted. After that, Jórunn married Eyjólfur Jónsson, the student, who was then in Sviðholt but who later moved to Skógtjörn at Álftanes and was thought to be a distinguished man in the region. They had a baby girl. She was named porgerður after her grandmother. Eyjólfur and Jórunn had not been together very long when it became evident that Jórunn had some kind of mental illness which became more serious as time passed, and in the end she went completely insane. It was suspected that her suitor's curse had caused the sickness.

When Porgerður Eyjólfsdóttir had grown to marriageable age, Eggert Bjarnason, who was at that time the priest at Snæfoksstaðir [Klausturhólum] in Grímsnes, proposed to her and married her. She thus went east with him and they had several children together. Time passed until Jórunn, Dorgerður's mother, died. She had never been mentally well since the time that misfortune came upon her after she was married. But there had been no signs of that sickness in Porgerður while her mother lived, since she had never returned south after going east. Reverend Eggert had even been warned about letting her go south, and people said that if she never went out past the river Sog or Álftavatn, then she would not be affected. But when Jórunn at Skogtjör died, it is said that Porgerður begged her husband to permit her to go south with him. He resisted at first but finally gave in when she pressed him further. Nothing is said of the couple's trip until they had come south over Hellisheiði, south into Fóelluvötn above Helliskot, where there it is said that she had a dizzy spell and that she was never the same again. Men suspect that her mother's ghost [fylgidraugur), that is, Porgarður, had met her there and followed her from then on as long as she lived, which was not for very long after that. The children of Eggert and Porgerður have, some thought, prospered little, and two of their daughters went mad. 
This account of Porgarður, the Móri of Sel, refers to no fewer than eighteen individuals by name and stretches across six generations of a single family. Of those named individuals, fifteen can be verified as historical persons-only Porgarður, Jón of Sel, and his wife Guðrún cannot be definitively identified. ${ }^{3}$ This feature of the story indicates something about the cultural memory behind the so-called fylgja tales (stories of attendant spirits) from nineteenth-century Iceland: stories of this type present a certain closeness, familiarity, even an intimacy between the ghost (if we may call them such) and whomever they haunt. These creatures become attached to individuals, families, or farms, and address themselves to the business of destruction, nuisance, obstruction, and sometimes murder. At other times there seems to remain some uncertainty about whether such creatures do good or evil. In some stories, fylgjur even seem to do a distorted kind of service for the family or person to whom they attend.

A certain confusion also arises about how exactly to categorize the ghost in this story. The narrative at times refers to him by the name he carried in life, Porgarður, at other times as a móri (a term I will discuss shortly), at still others he is called a draugur (ghost), ættarfylgja (family ghost), or fylgidraugur (attendant ghost). Are these terms interchangeable? The two words most commonly associated with Porgarður-fylgja and draugur-hold deep connections in the Icelandic/Old Norse cultural memory. The word draugur, usually translated as "ghost," can claim its origins in the Proto-IndoEuropean word dhroughós (Sanskrit drógha-), or "phantom,"4 yet scholars and editors of medieval Icelandic texts often comment that the Icelandic "ghost" does not fit the normal European expectation of a non-physical apparition, having instead a physical form, perhaps more like zombies than phantoms. ${ }^{5}$ A fylgja (pl. fylgjur) in pre-Christian times was a (female) guardian spirit, and the verb form, að fylgja, means to follow, to help, or to guide. ${ }^{6}$ These considerations - the historical persons, the closeness of Porgarður the attendant spirit, the ambiguity about his good or bad intent, and the long history of the words draugur and fylgja-highlight three straightforward though fundamental questions about the story of Porgarður, the Móri of Sel: What exactly is he? What are the origins of these stories? And what purpose do these stories serve in the Icelandic cultural memory?

Answering these questions requires some care because the dead often evade categorization in Iceland. In an important study of stories adjacent to the fylgja tales

3 Information on these persons can be found in “Mannanöfn, Drauga og Vætta," JÁ 6:67-182.

4 J. P. Mallory, Oxford Introduction to Proto-Indo-European and the Proto-Indo-European World (Oxford: Oxford University Press, 2006), 409.

5 Kent Michael Pettit has done a thorough analysis of this point in "Christmas Eve of The Living Dead: The Corporeal Undead vs. Icelandic Christianity" (PhD diss., Saint Louis University, 2018), especially 49-78. See also Ármann Jakobsson, "Vampires and Watchmen: Categorizing the Medieval Icelandic Undead," Journal of English and Germanic Philology 110 (2011): 281-300, especially "The Old Norse Term Draugr" (283-85).

6 Cleasby and Vigfusson, Icelandic-English Dictionary, s.v. fylgja. 
(such as the account of Porgarður), Terry Gunnell looks closely at the origins and functions of sendingar narratives-stories about animation of the recently (or nearly) deceased for the purposes of "sending" them to do harm to another person. ${ }^{7}$ Gunnell's study examines the functionality of these tales, tracing sendingar narratives from their earliest possible sources in Sámi magic lore to the parts of Iceland where the stories enjoyed the most popularity, namely in the Westfjords and northern Iceland. Gunnell deduces along the way why and for what purpose the characters within these stories might have served to the communities that sustained them, arguing that these stories "pass on a great deal about cultural connections, inherited views, cultural concepts and the cultural vocabulary adopted to explain things that rural people in the past did not understand." Along similar functional lines drawn by Gunnell, Ármann Jakobsson has complicated our understanding of Icelandic ghosts by arguing that our modern perception of medieval Icelandic ghosts have been heavily influenced by the editorial and classification practices of Jón Árnason. ${ }^{9}$ Ármann revises those classifications of medieval Icelandic ghosts by examining their "functions," or the purpose they serve in the narrative, in respective medieval Icelandic texts. The fylgja group, I suggest, allows for a functionalist approach similar to that outlined by Terry Gunnell and Ármann Jakobsson: by observing the function of these creatures, we have the opportunity to understand something about the "cultural connections, inherited views, cultural concepts and the cultural vocabulary" embedded within these tales.

\section{Origins and the Muddling of the Fylgja Group}

Post-medieval Icelandic folktales of the fylgja group have long been dissociated from the fylgjur, sometimes referred to as attendant spirits, of Old Norse literature and pagan belief. This is a view supported by the eminent Icelandic folklorist, Einar Ólafur Sveinsson. ${ }^{10}$ One can easily see why. After the medieval period, virtually no textual evidence exists to indicate that the memory of the medieval iteration of the fylgja was sustained. Despite this dearth of textual evidence, recent surveys on beliefs in the psychic and supernatural in Iceland may suggest that belief in fylgjur remains alive in the minds of Icelanders. As Erlendur Haraldsson puts it, "there is more belief in the fylgja phenomenon than in any other Icelandic-specific psychic form, with $28 \%$ of

7 Terry Gunnell, "Waking the Dead: Folk Legends Concerning Magicians and Walking Corpses in Iceland," in News from the Other Worlds: Studies in Nordic Folklore, Mythology and Culture, ed. Merrill Kaplan and Timothy R. Tangherlini (Berkeley: North Pinehurst Press, 2012), 235-66. I focus below on the fylgja group and refer readers interested in sendingar to Gunnell's study.

8 Gunnell, "Waking the Dead," 261.

9 Ármann Jakobsson, "Vampires and Watchmen," 281-83. Ármann (rightly) points out that Jón Árnason was heavily influenced by German principles of classification due to the authority of German folklorist Konrad Maurer, who was intimately involved with the Icelandic collection of folktales in the nineteenth century (Isländische Volkssagen, 281).

10 Einar Ólafur Sveinsson, Folk-Stories of Iceland, 187-88. 
respondents considering it certain or likely, $42 \%$ possible, and only $22 \%$ rejecting it as impossible or unlikely."11 How far back this cultural memory of fylgjur goes is perhaps a matter of debate, but it should be clear that fylgja stories have had a strong impact upon Icelandic beliefs in the supernatural. ${ }^{12}$ The earliest post-medieval written references to fylgjur as "attendant spirits" is from the seventeenth-century work on ghosts by Gísli Vigfússon (1637-1673), though the comments are preserved only the still-unpublished Islandiæ Nova Descriptio of Peder Hansen Resen, $1625-1688 .{ }^{13}$ In the eighteenth century, Jón Steingrímsson described a flugumýrarskotta, which, in the fashion of the nineteenth-century fylgjur discussed below, appeared before a priest who was coming to visit Jón. Einar Ólafur Sveinsson argues that these later fylgjur have little to do with the pre-Christian supernatural figure of the fylgja. In Einar's words, "The [earlier and later examples] of spirit have thus little more than the name fylgja in common."14 Einar would prefer to see these later fylgjur associated with the so-called sendingar (sg. sending), which are animated ghosts who, as mentioned above, are "sent" at their master's command in order to do harm to others. Einar goes on to say that "Attendant spirits' are people called up from the dead, ghosts raised by a magician."15 There is no doubt that a significant overlap existed between the two folk figures-i.e., often fylgjur are also sendingar ${ }^{16}$ - but there may be more of a distinction than has previously been acknowledged on this point.

Sendingar are prevalent in the later folk belief, but however connected the sendingar may be to a corpse, it is difficult to call them a ghost, zombie, or reanimated corpse. They do not walk of their own accord; they do not have their own will; they often embody only a small part of the original corpse (a bone or a heart); and in some cases the sendingar roam as a vapour or a fly, not apparently contingent upon a corpse at all. They furthermore do not have their own identity, a point driven home by the earliest evidence of sendingar, in the fourteenth-century narrative entitled porleifs páttr jarlsskálds (The Tale of Porleifur, the Earl's Poet), in which the sending is actually given a new name. ${ }^{17}$ Nor do they have their own strength, for the magician must strengthen $(a ð$

I I Erlendur Haraldsson, "Psychic Experiences a Third of a Century Apart: Two Representative Surveys in Iceland with an International Comparison," Journal of the Society for Psychical Research 75 (2011): 86.

12 See also Hrefna Sigríður Bjartmarsdóttir's excellent MA thesis, “'Ég er aldeilis ekki ein ...: Framliðnir sem fylgjur og verndarvættir í pjóðtrú” (MA thesis, Reykjavík, 2015) for a thorough discussion in Icelandic of beliefs in fylgjur.

I3 See Einar Ólafur Sveinsson, Folk-Stories of Iceland, 91.

I4 See Einar Ólafur Sveinsson, Folk-Stories of Iceland, 187-88, and sources cited there, for a more involved discussion of the later evidence.

15 Einar Ólafur Sveinsson, Folk-Stories of Iceland, 187-88.

16 For the most thorough and recent discussion on sendingar, see Gunnell, "Waking the Dead," 235-66, especially 239-53.

17 This saga may be the earliest Icelandic testimony to sendingar, but their origins may be much more complex. For an engaging discussion on possible Sámi origins, see Gunnell, "Waking the Dead," 253-59. 
magna) the sending in order to animate it. While there is sufficient evidence that fylgjur at times share some of the same characteristics, ${ }^{18}$ there is also evidence to suggest that the sending group and the fylgja group should at times remain separate because, as will be argued here, the fylgjur of post-Reformation folktales have a much stronger connection with their distinctive pre-Christian predecessors than has previously been acknowledged. While the later types of fylgja represent a much-changed version of their medieval ancestors, significant similarities persist between the earlier and later fylgja figures. Understanding how fylgjur from the earlier and later eras relate to one another facilitates a better understanding of how belief developed throughout religious development in Iceland, starting in the pre-Christian era and moving through Christianization and beyond.

\section{Pejoration and Attendant Spirits in Old Norse Sources}

The term fylgja has a long and rich history, if not a consistent one. Even in Icelandic belief today, fylgjur must be separated into two distinct groups: one that "follows" a specific family and another that is more of a spirit that accompanies a specific person. ${ }^{19}$ Regarding earlier beliefs in fylgjur, it is generally correct to acknowledge, along with Jón Árnason himself in his introduction to the fylgja group, that the tales collected in the nineteenth century are not themselves the same as the stories of fylgjur we see in Old Norse sources. Yet there persists enough diachronic, comparative evidence to indicate that the later fylgja tales are the late offspring of those earlier mythological beings, and acknowledging such a heritage brings us closer to understanding the development of folk belief in Iceland.

In Old Norse myth and literature, three supernatural beings, fylgjur, hamingjur (sg. hamingja), and dísir (sg. dís) were identified as attendant spirits. Linguistically, the terms dís and hamingja hold more straightforward connotations. The word dís generally refers to a goddess or priestess, but in the terms discussed here it denotes a female guardian spirit. ${ }^{20}$ The word hamingja can suggest outright luck or fortune while still holding on to the meaning of a guardian spirit. Cleasby and Vigfusson remark that hamingja and fylgja are contextually almost synonymous, for hamingjur, like fylgjur, often take the shape either of an animal or of a human, typically female. The hamingjur

18 For the connections between sendingar and fylgjur, see Einar Ólafur Sveinsson, Folk-Stories of Iceland, 188; Gunnell, "Waking the Dead," 250; Ármann Jakobsson, "Vampires and Watchmen," 282.

19 See Terry Gunnell, "Modern Legends in Iceland," in Narratives across Space and Time: Proceedings of the 15th Congress of the International Society for Folk Narrative Research (June 21-27, 2009, Athens), 2 vols. (Athens: Academy of Athens, Hellenic Folklore Research Centre, 2014), $1: 345 n 12$.

20 I skip over the notion of a dís as a "sister." Cleasby and Vigfusson discuss the etymology of the word in their entry in their Icelandic-English Dictionary. Especially of interest is Grimm's suggestion that Tacitus may have corrupted Idisaviso from Idisiaviso, "the virgin-mean." See Cleasby and Vigfusson, Icelandic-English Dictionary, s.v. dís. 
may be connected to the nornir, or the "hamingjur of the world."21 The word fylgja, however, has more diverse connotations. As a noun it can hold the connotation (even in modern Icelandic) of a spirit or ghost, but it can also refer to the placenta, meaning that which follows or attends the newborn child..$^{22}$ In Old Norse, specifically, the noun fylgja can refer to a spirit, especially to a pagan female attendant spirit, ${ }^{23}$ who watches after and sometimes reveals the fate of the individual it attends. As mentioned above, the verb að fylgja means "to follow," "help," or "guide." The attendant spirit grants assistance to a person or a family, and also goes before them, which supports the notion, discussed below, of a person's fylgja appearing somewhere before they do. The connotation "to back," or "to help," leads to the prefix fylgi-, meaning help or support. ${ }^{24}$ A fylgisamur is a faithful follower, fylgð is a "following" or "backing," and the adjective fylginn means "adherent."

Clearly, the terms are complicated, as they appear in different contexts and circumstances that often shade meaning. ${ }^{25}$ Even acknowledging the differences between the fylgja and the more Christian version of a soul, fylgjur often appear as rather unique figures in the Old Norse literature. Some fylgjur act more like the Valkyries of Norse mythology, serving to direct the fates of living individuals. These attendant figures, who, as noted above, are variously referred to as fylgjur, dísir, and hamingjur, stand as independent entities, bear no resemblance to the soul, though very much interested in the fate of the individual they serve. Hilda Roderick Ellis remarks on the difference between the two types of figures, making a distinction between animal fylgjur, which more closely resemble the soul, and another type of fylgja-often a fylgjukona (fylgjawoman) or kynfylgja (family-fylgja) — which functions as more of an attendant of the

2 I Cleasby and Vigfusson, s.v. hamingja. The word has come to be a blessing in Christian times: "leggja sína hamingju með e-m."

22 The notion is not surprising, given the remarkable mythological significance attributed to the placenta in various cultures.

23 See below for my discussion of Else Mundal's monograph on fylgjur in Old Norse sources, where she points to the importance of the feminine associations with these medieval supernatural creatures. See Else Mundal, Fylgjemotiva i Norrøn Litteratur (Oslo: Universitetsforlaget, 1974).

24 Cleasby and Vigfusson, Icelandic-English Dictionary, s.v. fylgi.

25 As Margaret Clunies Ross points out in Prolonged Echoes: Old Norse Myths in Medieval Northern Society, The Viking Collection 7 (Odense: Odense University Press, 1994), 245, several scholars have debated the meanings of these words. See Folke Ström, Diser, nornor, valkyrjor. Fruktbarhetskult och sakralt kungadöme $i$ Norden, Vitterhets Historie och Antikvitets Akademiens Handlinger, Filol. -filos. Ser. 1 (Stockholm: Almqvist \& Wiksell, 1954); E. O. G. Turville-Petre, Myth and Religion of the North: The Religion of Ancient Scandinavia (London: Weidenfeld and Nicolson, 1964); Peter Hallberg, "The Concept of Gipta-Gæfa-Hamingja in Old Norse Literature," in Proceedings of the First International Saga Conference, University of Edinburgh, 1971 (London: London Viking Society for Northern Research, 1973), 143-83; Mundal, Fylgjemotiva; Dag Strömbäck, "The Concept of the Soul in Nordic Tradition," Arv: Tidskrift för Nordisk Folkminnesforskning 31 (1975): 5-22; Lars Lönnroth, Njáls Saga: A Critical Introduction (Berkeley: University of California Press, 1976). 
individual than it does a soul or spiritual extension of the person. ${ }^{26}$ She later sharpens the image, saying of the two types of attendant spirits:

one is that of the animal fylgja, which might be translated "fetch"; it accompanies a human being through life, can be seen by others in dreams or in waking hours if they have the gift of second sight; and the life of the owner depends on its well-being ... The other conception ... is that of a supernatural woman guardian, who attends an individual until death, and survives him; after his death he is able to enter her abode, and she then attaches herself to another, often in the same family. ${ }^{27}$

Independent though they are, a certain type of fylgja-as personal spirit-clearly symbolizes much about the character, origins, and fate of the person(s) it attends. In the only monograph-length study of fylgjur in Old Norse sources, Fylgjemotiva i Norrøn Litteratur, Else Mundal follows to some degree the work of Ellis and separates animal fylgjur from female fylgjur. The former, if they appear alone, tend to represent the alter ego of the person attended and, if they appear in groups, tend to represent a warning of an enemy's attack. ${ }^{28}$ The latter function reflects the guardian spirit of a group or clan and may ultimately be connected to worship of maternal goddesses. ${ }^{29}$

Literary evidence in Old Norse sources is diverse. In chapter 11 of Hallfreðar saga, a fylgjukona comes to Hallfreður and declares that their relationship has come to an end (of course, this bodes ill for Hallfreður); she then negotiates the transferral of her guardianship to Hallfreður the younger, an arrangement that seems to please all parties involved. ${ }^{30}$ Ellis observes in this passage and numerous others like $\mathrm{it}^{31}$ that spiritual

26 Hilda Roderick Ellis, The Road to Hel: A Study of the Conception of the Dead in Old Norse Literature (New York: Greenwood, 1968), 130-31. Ellis remarks in a footnote that this concept of a guardian attendant might be accounted for by Christian teaching, particularly in light of Njáls saga, in which Hallr agrees to the conversion to Christianity only if St. Michael will become his fylgjuengill, his fylgja-angel (Road to Hel, 130). However, as DuBois and Clunies Ross argue (see below), while the notion of attendant spirits would have found a correspondence in Christianity, the notion has a prevalent place in Norse paganism as well. The important question to ask here, then, is how the belief actually metamorphosed, what with the likely correspondence between the two belief systems. The current chapter suggests that the attendant figures fragmented throughout metamorphosis, rather than preserving an intact development.

27 Ellis, Road to Hel, 138.

28 See Hedin Brønner's review of Mundal's monograph, in Scandinavian Studies 48 (1976): 335.

29 For a thorough discussion of one candidate that fits this paradigm, see Gunnhild Røthe, "Porgerðr Hölgabrúðr: The Fylgja of the Háleygjar Family," Scripta Islandica 58 (2007): 33-55, especially $46-47$ and 53.

30 Hallfreðar saga, in Vatnsdæla saga: Hallfreðar saga, Kormáks saga, Hrómundar páttr Guðrúnarsonar, ed. Einar Ólafur Sveinsson, Íslenzk Fornrit 8 (Reykjavík: Hið Íslenzk Fornritafélag, 1939).

3I For instance, Vatnsdæla saga, chap. 34; Völsunga saga, Fornaldar Sögur Norðrlanda 1, ed. Guðni Jónsson (Reykjavík: Íslendingasagnaútgáfan Haukadalsútgáfan, 1953-54), chap. 4; Helgavkiða Hjörvarðssonar, in Edda: Die Lieder Des Codex Regius Nebst Verwandten Denkmälern, ed. Hans Kuhn (Heidelberg: Winter, 1983); Göngu-Hrólfs saga. Fornaldar Sögur Norðrlanda 3, ed. Guðni Jónsson (Reykjavík: Íslendingasagnaútgáfan Haukadalsútgáfan, 1953-54), 161-280, chap. 32; Óláfs 
attendants (whether called fylgja or hamingja) work to affect the fate of the individual(s) under their protection. Generally, the guardian spirit's services benefit the individual, though not always; the fylgjukona in Hallfreðar saga is often an agent of the ill fate suffered by the one under her care. At certain significant times, the guardian spirit will transfer its allegiance to another individual, often a descendant or friend, and at other times, it will be lent to another individual, as in chapter 22 of the much later Porsteins saga Víkingssonar (The Saga of Porsteinn, Viking's Son). ${ }^{32}$ The diversity of references to fylgjur, hamingjar, and dísir makes it difficult to set down an accurate description of these supernatural figures. It is important to note the distinction between the two types of attendant spirits in Old Norse belief, but while Ellis's distinction appears to hold fairly consistent, there do not appear to be any hard and fast rules that articulate the characteristics of these figures.

After the introduction of Christianity into the Norse belief system, these attendant spirits take on a different functional identity in narratives about conversion. The shift can be seen in a number of places, perhaps most remarkably in the well-known story piðranda páttr ok Pórhalls (The Tale of Piðrandi and Pórhall), ${ }^{33}$ where two competing bands of fylgjur vie for the life of piðrandi at the farmstead of Síðu-Hallur, who, incidentally, is said to have played a key role in Iceland's conversion to Christianity. Nine horse-women in black tear piðrandi to pieces before nine women in white can arrive to defend him. From the arrival of these apparitions, the prophet Porhallur predicts that conversion is imminent. Of the episode, John Lindow states, "some time between the late twelfth and late fourteenth century, a learned author saw little difference between fylgjur and dísir and saw no difficulty depicting them in terms of color symbolism to represent opposition between the old faith and the new." 34 Thomas A. DuBois similarly suggests that the concept of attendant or guardian spirits has a long and rich representation in all Nordic religions, remarking further that the tradition would have found a likely correspondence in the Christian concepts of the guardian angel and saints. ${ }^{35}$ Be that as it may, it seems unlikely that the Nordic figures would have derived from the same tradition as the Christian guardian angels. Margaret Clunies Ross argues that "the concept of a tutelary spirit is widespread in early Norse culture

saga Tryggvasonar, in Heimskringla 1, Íslenzk Fornrit 26, ed. Bjarni Aðalbjarnarson (Reykjavík: Hið Íslenzka Fornritafélag, 1941), 225-372, chap. 1. In some of these examples the attendant spirit is referred to as a hamingja. Ellis discusses many additional examples of a similar ilk; see Road to Hel, 130-38 for her analysis.

32 Porsteins saga Víkingssonar, in Fornaldar sögur Norðurlanda, ed. Guðni Jónsson, 4 vols. (Reykjavík: Íslendingasagnaútgáfan, 1954 [1981]), 3:1-73.

33 piðranda páttr ok pórhalls, in Íslendinga sögur, ed. Guðni Jónsson, vol. 10 (Reykjavík: Íslendingasagnaútgáfan Haukadalsútgáfan, 1953-54), 371-78.

34 John Lindow, Norse Mythology: A Guide to the Gods, Heroes, Rituals, and Beliefs (Oxford: Oxford University Press, 2002), 97.

35 Thomas Andrew DuBois, Nordic Religions in the Viking Age (Philadelphia: University of Pennsylvania Press, 1999), 57. 
and is unlikely a foreign import."36 Along this line of thinking, it seems unlikely that the fylgja as attendant spirit would have vanished without a trace after the medieval period.

In a study adjacent to Ellis's, Dag Strömbäck examines the concept of the soul in Nordic tradition, stating that one consistent theme in the Norse concept of the soul is "the belief in the soul as a spiritual element, not only incorporated in the individual but also more or less invisibly emanating or-if I may say so-radiating from an individual and capable of exercising influence at a distance." ${ }^{37}$ Indeed, the latter portion of this statement can be attested to by the fact that fylgjur often act as an agent for the one they attend, going before them and causing a drowsiness or other affliction to come over their attendee's enemies, as in Sturlunga saga, Njáls saga, and other sources. ${ }^{38}$ Strömbäck also cites examples of this phenomenon in later Nordic folktales in the form of an attack (Icelandic aðsókn, a term that, according to Strömbäck, refers specifically to this sort of aggression) that one's soul can make on another individual. In the later traditions the attacks, interestingly enough, can be involuntary, in which case the individual whose "soul" has executed the attack must often pay compensation for the damage done. ${ }^{39}$

These literary instances may serve as markers of the attendant spirit's place in Norse pre-Christian belief, though more likely (at least more verifiably) they indicate how early Christian Icelanders viewed them. Both possibilities are worth noting, but in order to discern how the perception of attendant spirits resolves, we must turn to the folktales of a later, post-Christianization, post-Reformation era. Jón Árnason dedicates a section of his folktale collection to fylgjur, citing their similarity to the attendant spirits of earlier belief. Árnason includes in his classification hamaskipti (shape-shifters); mannafylgjur and aðsóknir (individual "followers" and attendants); $;^{40} æ t t a r d r a u g a r$, mórar og skottur (family ghosts called mórar and skottur);1 and lastly bæjardraugar (farm ghosts). The classification of these beings as fylgjur is problematic, however, since it remains questionable how much they ought to conjure images of attendant spirits from Old Norse accounts. Einar Ólafur Sveinsson agrees that all of these figures are

36 Clunies Ross also remarks that, unlike Old Icelandic prose, the terms fylgja and hamingja are rarely used in the mythological poetry and in Snorri's Edda, the term norn being found more frequently to identify guardian figures (Clunies Ross, Prolonged, 246). On the norn see: Karen Bek-Pedersen, The Norns in Old Norse Mythology (Edinburgh: Dunedin Academic Press, 2011).

37 Strömbäck, "Concept of the Soul," 16.

38 See Strömbäck, "Concept of the Soul," 5-7, for additional commentary and examples of this type of agency.

39 Strömbäck, "Concept of the Soul," 14-15.

40 The word aðsóknir obviously has a strong connection to the verb að sókna or sókna, which Strömbäck refers to as an act of aggression. See above.

4I The words mórar (sg. móri) and skottur (sg. skotta) are commonly viewed as proper nouns though Einar Ólafur Sveinsson translates them as "Rufuses" and "Long Caps." I will use the Icelandic forms here. 
certainly attendant spirits, but he also makes a distinction between them and the fylgjur of earlier Norse belief:

The belief in "attendant spirits" is clearly no new thing here at this time, but it is unlikely that it was very widespread until the late seventeenth century, or even until on in the next century ... These "attendant spirits" had one thing in common with the class of spirits known by the same name in ancient Iceland (fylgjur, "guardian spirits"), they went in front of the person to whom they were attached, but these did nothing but evil, both to that person and to others, while the ancient guardian spirits did no harm, unless their "owner" was an evil person or in an evil mood ... The two types of spirit have thus little more than the name fylgja in common. ${ }^{42}$

While the differences between the ancient belief and the later are inescapable, I suggest four additional similarities between the ancient supernatural attendant spirits and those ghosts in the fylgja folktales collected by Jón Árnason. First, we cannot ignore that these later ghosts are "inherited," as it were, by family members of subsequent generations, which indicates a familial connection like that observed in Hallfreðar saga and other stories. Second, certain of the later tales present a fylgja as soul, much in the same forms indicated by Ellis and observed in more detail by Strömbäck. Third, despite the fact that the later ghosts generally do harm, they are often observed trying to do something akin to a beneficial service, demented though it may be, for their "owner." True, their efforts never turn out well, but the benevolent intent remains. Fourth, much like earlier versions of fylgjur, who exacted punishment upon their owners, the fylgjur of the later folktales punish their owners for the evils they commit. These common traits of the earlier and later attendant spirits of Old Norse/Icelandic sources indicate a pejoration process-similar to what occurred in the development of the "Deacon of Myrká." Thus, when viewed through a functionalist lens, the evidence suggests a stronger continuity between the earlier and later traditions of attendant spirits than has traditionally been assumed.

\section{Post-Medieval Fylgja Tales}

\section{Inheritance (Genealogically and Geographically) of Attendant Spirits}

Unlike, for instance, tales about God and the Devil or otherworldly journeys, fylgja tales are more likely to have developed around specific localities and persons, which makes it not altogether surprising to find information of this sort in them. Even so, two significant points may be drawn from the prevalence of such details. For one thing, information on persons and places lends a substantial sense of verisimilitude to the tales, not only for the reader but also, and more importantly, for those who transmit them orally from one person (or group of people) to another. In the tale "Hvítárvalla-Skotta" (The Skotta of

42 Einar Ólafur Sveinsson, Folk-Stories of Iceland, 188. Simpson echoes this sentiment in her note to "Irafells-Móri," one of the few fylgja tales to have been translated into English (Icelandic Folktales, 161-62), although her translation cuts out portions of the original. 
Hvítárvellir), ${ }^{43}$ the narrative begins with a detailed account of who was involved, what their occupation was, and where they were born and to where they lived later. A portion of this information, such as the dates of Sigurður's service as district magistrate in Borgarfjörður, might have been verified and supplied by the recorder of the tale, but those who told and heard it would have known the information (perhaps including the rough dates of his appointment). Throughout the tale, we are given Sigurður's descendance through four generations, and the hauntings are traced throughout, complete with details about second marriages and speculations on which generations were most affected by Skotta's hauntings. The "hauntings," interestingly enough, seem to follow the female line, rather than the male. ${ }^{44}$ This makes a great deal of sense, given that Skotta began haunting the family, it is supposed, because Ólöf, Sigurður's wife, offended a scorned suitor. Likewise, after the death of Jón's daughter Ragnheiður, Skotta began to follow her daughter, Kristín, who had by that time married. Other tales exhibit a similar dependence upon genealogy. "Hleiðrargarðs-Skotta" (The Skotta of Hleiðrargarður) ${ }^{45}$ and other additions to the tale, "Árbæjar-Skotta eða Nýjabæjar-Skotta" (The Skotta of Árbæjar or of Nýjabæjar) ${ }^{46}$ most directly, but all the tales about mórar and skottur rely either upon genealogy or, on occasion, close friendship to solidify the logical progression of hauntings. Sometimes the curse is given a specific time limit, nine or fifteen generations, and other times the haunting lasts an indefinite amount of time. In all the tales, however, the genealogy fixes the haunting in a "reality" that would otherwise never be realized by listener or reader.

Genealogies, historical characters, and specific geographies also, speaking to the second point of interest, enable a special kind of intimacy both between the persons referred to in the stories and between the characters in the stories and those who told and heard the tales of Icelandic fylgjur. This may be the most important aspect of these stories, as it illuminates a fundamental truth about fylgjur of any era, early or late. In the plainest of terms, the fylgjur follow; they attend; they guide; and they persist. For better or worse, as a help or a hurt, the supernatural creatures in these stories are in the lives of those to whom they tend. As such, they take upon themselves the identities of their respective families, so that the appellations of ættarfylgja (family ghost), mannafylgja (personal attendant spirit), and bæjardraugur (farm ghost)—problematic though they may be-carry important connotations of closeness and intimacy. The names and locations offered in these stories are important not merely because they can be verified now, long after they were recorded, but most importantly because they would have meant something to the people telling the stories in the first place. It is

43 JÁ 1:348-52.

44 Sigurður had no female offspring, and his son Jón was curiously unaffected by the haunting. Not until Jón's daughter, Ragnheiður, reaches a marriageable age does the haunting continue. The same trend is apparent in "Sels-Móri eða Porgarður" (JÁ 1:373-76).

45 JÁ 1:354-58.

46 JÁ 1:360-61. 
perhaps difficult for the modern mind to perceive, but in both the medieval and postmedieval Icelandic world (even into the nineteenth century, when these tales were recorded), the farmstead was the centrepiece of the entire social structure. Kirsten Hastrup notes that one social constant during the late medieval and post-medieval periods was

the conception of the bú and farmstead, bær, as the pivot of social organization, in relation to which more peripheral orders were "measured." This remained true right up to the end of the nineteenth century, for no urbanization took place until then. This is one of the main differences between Iceland and other Nordic countries, for in the latter the social division of labour was reflected in geographical separation. In Iceland all specialist tasks had to be carried out within the household during the entire period. ${ }^{47}$

With this social structure in mind, it must be clear that the specific personal names and geographic localities referenced so frequently in fylgja tales were not points of interest to the historian only; they would have been known by the tellers and hearers of the stories. The eighteen names and six generations of the Porgarður narrative were not merely detached or unknown to the people telling the story. Listeners might easily have been related to these people; they certainly could walk the landscape around their farm to find the places where certain narrative events occurred. Thus, much as the attendant spirits perceived in the Old Norse tradition, the fylgjur of later folktales are transmitted along genealogical lines.

It will not be surprising, then, that Jón and Guðrún of the Porgarður narrative are haunted all their lives, and that their only child, a daughter named porgerður, inherits the fylgja. So it goes for the six generations referenced in the story. Porgerður marries Halldór Bjarnason, and they have two children, Bjarni and Jórunn. Interestingly, as in the case of several other fylgja tales, the male child is exempt from the haunting here (though Bjarni's daughter, Puríður, is later haunted). Jórunn, Halldór's daughter, is greatly affected by Sels-Móri (as Porgarður comes to be known), and is even cursed by another ghost. Jórunn marries Eyjólfur, and their child, Porgerður (named after her grandmother), grows up to marry a good man named Eggert. No doubt this emphasis on the female heir goes back to Guðrún's, not Jón's, rejection of Porgarður.

At this point geography becomes a vital factor, as Eggert and Porgerður move east, escaping the family curse presumably because the ghost cannot be in two places at once (he still haunts Jórunn at this point). Things go well until Jórunn dies from her affliction and porgerður goes south to mourn the loss. When the couple get close to her parent's home, porgerður becomes infected by her mother's insanity and dies shortly thereafter. As is clear from the tale, Móri's haunting obeys what seem to be predetermined rules of inheritance. This and other tales go so far as to establish the number of generations that will suffer under the ghost's curse. More importantly, people close to the family seem to understand the logic behind the rules, for many warn Eggert against the journey south.

47 Hastrup, Nature and Policy, 48. 


\section{Fylgjur as Souls (Aðsókn or Hugr)}

In the Old Norse sources there is one conception of an attendant spirit that stays with an individual through life as a kind of alter ego or perhaps soul, sometimes translated as a "fetch." Most often thought to take an animal form, fetches tend to go before the individual they attend, announcing their arrival or presence, as well as betraying various characteristics of the person. They can be seen by those who have second sight, and the well-being of an individual depends upon his or her fetch. These mythical figures have a direct correspondence in the later fylgja tales, and often these later figures act in much the same way as their Old Norse predecessors. In Jón Árnason's collection, five fylgja tales deal with this type of figure: "Dalakúturinn" (The Treasure Cask), ${ }^{48}$ "Tvær sagnir um fylgjur" (Two Stories about Fylgjur), ${ }^{49}$ "Peir koma pá fjórir" (They Come then Four), ${ }^{50}$ "Galtardalstófa" (Galtardalur's Fox), ${ }^{51}$ and "Anna á Bessastöðum" (Anna at Bessastaðir). ${ }^{52}$ In "Dalakúturinn," a group of travellers stops to rest and all but one go to sleep. This last man sees a blue light escape the travellers' tent, and he follows the light over the landscape to a certain point, before returning. When the sleepers wake, one of them (from whom the light originated) gives an account of a strange dream he had in which he went on a journey to find a chest of gold. The waking man then laughs, saying that he had seen the man's fylgja, at which point they all follow the same path to find the gold. The tale mirrors the Old Norse belief that certain clairvoyant individuals can see the fylgja of another person, and somehow benefit from this ability.

This tale type (ML 4000: Soul of a Sleeping Person Wanders on its Own) is prevalent across Scandinavia and, remarkably, the Albigensians circulated a strikingly similar variant $^{53}$ in southern France throughout the twelfth, thirteenth, and fourteenth centuries. The connection between the two tales is inescapable, but equally striking are their different conclusions. In the Albigensian version, the events proceed much the same way: One individual goes to sleep and another sees a lizard come from the sleeper, cross a river in the same manner as in "Dalakúturinn," and attempt to return to his body. Perhaps unsurprisingly, however, the Albigensian tale foregrounds and exemplifies the transmigration of an individual's spirit. At its conclusion the two characters are baffled by the events and go to a parfait (an Albigensian "priest," as it were) for aid. The parfait interprets the event, saying, "the soul ... remains in a man's body all the time; but a man's spirit or mind goes in and out, just like the lizard which went from the sleeper's mouth to the ass's head and vice versa... ${ }^{4}$ The function of the spirit here is nearly identical to
48 JÁ 1:342-43.
49 JÁ 1:344-45.
50 JÁ 1:345.
5I JÁ 1:345.
52 JÁ 1:346.

53 The Albigensian account is recorded in Emmanuel Le Roy Ladurie's Montaillou: The Promised Land of Error (New York: Braziller, 1978), 351-52.

54 Le Roy Ladurie, Montaillou, 352. 
that of the fylgja in the Icelandic tale, yet the tales' purposes differ greatly. Whereas the Albigensian tale means to promulgate doctrine, the Icelandic tale means only to share an anecdote about treasure hunting, in which transmigration merely plays a certain role. The difference indicates that fylgjur of this sort had strong roots in the Norse tradition, for in the tale there is no need for the characters to question or inquire of a wise man, nor are they baffled by the fylgja. It is simply something that happens. In contrast, the Albigensian transmigration sparks inquiry and wonderment, indicating that the culture was not as comfortable with the concept.

A similar clairvoyance plays a role in "Tvær sagnir um fylgjur" and "Peir koma pá fjórir," in which the ability to see the fylgjur of others lends motivation to the anecdotes. In "Anna á Bessastöðum" the concept of the fetch plays a more vital role. The tale takes place in a fishing village, where Anna, herself clairvoyant, serves the fishermen, making them coffee and doing other such things to help around the fishing camp. One morning she goes down to the shore and sees sixteen men coming out of the sea, all of them soaked. When she asks whether they have just landed, she gets no answer. Thinking this strange, she goes into the house where the fishermen stay, only to find them around the fire, having not even put on their fishing clothes. Knowing that she has seen their fylgjur, Anna warns them not to go out that day, as the omen bodes ill for them. None listens to her, and all die in a horrible storm. Here, the fylgjur clearly represent the souls of the men, much as they would have in Old Norse belief; being clairvoyant, Anna takes on the role of guardian figure, rather than the fylgjur (of a different sort) guarding over the individuals they attend. As such, the tale suggests a kind of split from the old belief. Anna is a female guardian (in Old Norse, fylgjukona), and looks after certain persons, but rather than being a fylgja herself, she must rely upon her ability to see the fetches to indicate when danger is near.

In "Galtardalstófa" the role of a female attendant echoes that of Anna. This time, however, the fetch does not reflect the person under guardianship but rather the perpetrator of the offence. The same clairvoyant girl who sees the fylgjur in "Peir koma pá fjórir" here sees a rust-brown fox that stands before a man (a clear reference to the older concept of a fylgja as one who "goes before") who wants to marry a certain woman, Margrét, though she has rejected him. The fox bears with it a curse that the woman will not be happy in her chosen marriage, as she will develop a spoiled temper. The curse echoes the reputation of the fox, for just as in English, the word tófa has in Icelandic the same connotation of a vixen, or a spiteful, mean-spirited woman. The second-sighted Guðrún sees the fox from afar and warns the appropriate parties, thus taking on the role of a guardian figure herself; and when people learn of it, they reckon that this fox is a sending conjured by the man she has rejected. The notion of the fox as a sending is an interesting one if taken alongside Dag Strömbäck's study of the soul in Norse societies. Strömbäck discusses the soul in terms of a spiritual extension of the individual that can actually have an effect on other people. These "emanations or radiations," as Strömbäck describes them, manifest in fylgjur as an attack upon another person, sometimes in the form of drowsiness, sneezing, or hiccups, or, in the more sinister forms, of sickness or death. Strömbäck refers to these attacks as "aðsókn," appealing to the Icelandic verb 
(að sækja). "Galtardalstófa" suggests a similarity between this function of the soul or fylgja and the function of a sending, which serves much the same purpose and is often conjured from similar motivation.

The connection holds particularly true in those cases where the sending is not an actual corpse but, as is often the case, a mist, a fly, or some sort of animal, which would be more characteristic of a fylgja. It is not too far afield to suggest that some crossover has taken place between the two folk beliefs, and this is certainly the case in "Galtardalstófa." With its references to the sending, the notion of a fetch as a soul, and the presence of the second-sighted guardian figure, this short tale (only about two hundred words) serves as a point of convergence for a variety of Icelandic motifs, though the intersecting motifs seem to hit upon a similar kind of life experience. It remains to ask how they are similar. For one thing, the characterization of the fox as both sending (as the people reckon) and the scorned man's fetch (aðsókn, to use Strömbäck's terminology) must suggest some association between the fox and, if not guilt, per se, then certainly offence. The woman stands guilty of an offence and she must suffer for it accordingly. The same sort of romantic offence motivates other tales about fylgjur, particularly those concerning malignant attendant spirits. As the discussion shifts from fetches to these æettardraugar, the relationship between culpability and attendant spirits becomes more pronounced. In these tales, however, punishment for the offence takes the form of either a young boy or girl (móri and skotta, respectively), who plays harsh tricks on the individual, killing livestock, destroying property, and sometimes even killing people. These ghosts also attach themselves to a certain family, transferring their attendance, much like the fylgjur of pagan belief, from one generation to the next.

\section{Pejorated Assistance}

Nowhere is the pejoration process in the development of fylgja tales clearer than in their function as spiritual helpers. Though they always ultimately bring about strife, it does not appear to be the case that the fylgjur of later folktales always seek to do their owners harm. Of family ghosts, or ættardraugar, one of the few translated fylgja tales (and, at that, only about half of it has been translated into English) shares the motif of a scorned lover. "Irafells-Móri" (The Móri of Irafell), ${ }^{55}$ shares the long and involved tale concerning Kort and his wife Ingibjörg and their descendants. Just as in "Galtardalstofa," Ingibjörg has rejected many lovers in order to marry Kort. Here, however, the rejected lovers collectively pay a wizard to dispatch a sending against the family, and demand that the ghost should follow the family for nine generations. People call the ghost móri, as he is seen wearing grey breeches, some sort of hat, and a rust-brown (mórauða) sweater, thus attaining his name (all mórar share a similar description). As the tale proceeds, however, the significance of the initial motive fades, and the haunting bears a distorted resemblance to the attendant spirits of Norse paganism. In one episode, one of Kort's sons, Einar, goes on a journey to Skrauthólar, and arriving late at his destination he looks

55 JÁ 1:364-73. 
in the cowshed for shelter, since he does not wish to disturb his hosts. Finding a stall in which to spend the night, he goes to sleep, but in the morning he discovers that the móri has actually arrived ahead of him and killed the cow that had occupied the stall, thus making room for Einar to sleep.

Two interesting aspects of the tale arise: First, that the móri precedes Einar indicates the same kind of motif intersection observed in "Galtardalstófa," in which the fox (a fylgja) goes out ahead of the haunted woman, Margrét. Irafells-Móri acts as Einar's fetch when he goes ahead of him, and yet the móri remains the sending charged with haunting Einar, son of Kort. Likewise, while inextricably bound to (and responsible for) the actions of his attendant spirit, Einar possesses no control over Móri's actions. In this episode, the móri stands, in a way, in the same position as the old pagan attendant spirits, for they too would act both according to their own volition and yet on behalf of the individual they served. The difference, of course, is that the pagan attendant spirits (generally) served the best interests of their charge, whereas the móri can hardly be said to do so. Nevertheless, and this brings me to the second point, although killing the cow remains consistent with Irafells-Móri's typical pattern of destruction, in this particular instance the destruction was meant as a service to Einar. ${ }^{56}$ The same type of service motivates the events of another anecdote later in the story of "Irafells-Móri," when Kort Kortsson lends his leather jacket to a friend, Porsteinn, for a windy horse ride home. When the two riders reach the point at which their paths diverge, Porsteinn goes on his way, forgetting to return the jacket to Kort. As he begins to ride away, Porsteinn feels something pulling at the jacket, and his horse falls down dead beneath him. It is believed in the tale that the móri was trying to return the leather jacket to Kort. True enough, this móri's "service" in both instances invariably does more harm than good, but it remains a distorted, perhaps grotesque, shadow of the attendant spirits of Norse pagan belief.

Though the account of porgarður does not directly mention any assistance to his family or attendee, it is clear from other post-medieval fylgja stories that such assistance-twisted though it may have been-was prevalent in other stories of fylgjur. One might deduce that some similar stories existed about Porgarður, crass and vengeful though he might have been.

\section{Retribution and Punishment}

In several cases the motivation for the haunting derives from a specific event, as in Porgarður's narrative. Likewise, in the tale "Móhúsa-Skotta" (The Skotta of Móhús), ${ }^{57}$ the attendant spirit begins its haunting not because of scorned love but because she herself has been scorned. The skotta, the female version of the móri-style fylgja, is so-called because she often wears the traditional Icelandic headdress, which is twisted or turned backwards on her head and dangling behind her like a tail (skotta). In "Móhúsa-Skotta"

56 Conceivably, the service is a kind of mockery, but even so, the distorted process remains intact. 57 JÁ 1:347-48. 
a certain man, Jón Pórðarson, lives in West Móhús, where he strives to acquire a fortune. On a night of particularly inclement weather, a young girl comes to his house asking for lodgings for the evening, but Jón turns her away for no apparent reason. The young girl dies of exposure and thus the haunting begins. Wherever Jón goes, she is nearby, going ahead of him to kill livestock and play evil tricks. That the skotta goes ahead of Jón recalls again the characteristic of the pagan fylgja, particularly the fetch-like version discussed by Ellis. Associating the skotta's fetch with the young girl's death suggests that the skotta also represents the girl's soul taking revenge upon Jón for not helping her, but unlike Strömbäck's aðsókn, the motif of a fetch has shifted from an extension of the soul to the soul itself. ${ }^{58}$ The benevolent ancient attendant spirit has become an avenger of wrongdoing, again a grotesque and twisted version of the old guardians. Even her name skotta, as mentioned above, refers to a tradition (the traditional headdress) that has been "twisted" backwards. But it must be remembered that pagan attendant spirits often punished those who had offended them. Lindow points to passages in Ynglinga saga, in which King Aldis is thrown from his horse and killed while riding by a site reserved for sacrifice to the disir. ${ }^{59}$ It seems then that the role of attendant spirit as benevolent guardian figure has fallen by the wayside and only the vengeful figures remain in the later folktales.

The same holds true in the two other significant tales: "Hítardals-Skotta" (The Skotta of Hítardalur) ${ }^{60}$ and "Hörgslands-Móri" (The Móri of Hörgsland) ${ }^{61}$ In "Hítardals-Skotta" the motivation for haunting arises again as a point of interest. Here, the priest Vigfús has been friends with another priest for many years, but when this friend commits a certain crime, the punishment of defrocking the priest falls to Vigfús. Afterwards, the defrocked priest vows revenge, and shortly thereafter Vigfús's demeanour changes for the worse and a skotta is seen near him. The defrocked priest clearly sends the skotta against Vigfús, and thereby the tale echoes stories of sendingar, but it also conjures images of the aðsókn mentioned above, and again the skotta serves as a vengeful spirit. Perhaps even more important than these observations, the tale confronts the audience with the question of whether Vigfús acts rightly when he defrocks his friend. Clearly, his friend sends the skotta to haunt him for this express reason (as no others present are cursed), and the particular curse laid down implies that the defrocked priest expects his friend to defend him: "Pú varðst pá, vinur, fyrstur til að færa mig af hempunni; vera má að pér pyki jafnmikið sem mér nú áður langt um líður" (You were then, friend, the first to defrock me; it may be that you will seem equally hard done by as I do now, before

58 A like motif appears in tales about útburði, or exposed children. In "Móðir mín í kví, kvî" (JÁ 1:217-18) a mother exposes her newborn baby girl, but later on, when she wants to go to a party but has no dress, the ghost of the girl appears to offer her mother her baby dress.

59 Yngvars saga víðförla, in Fornaldar Sögur Norðrlanda 2, ed. Guðni Jónsson (Reykjavík: Îslendingasagnaútgáfan, 1976), 423-59.

60 JÁ 1:351-52.

6I JÁ 1:363-64. 
too long). ${ }^{62}$ The haunting by the skotta serves as a kind of penance for Vigfús, and the subsequent haunting as a reminder to his family.

The tale "Hörgslands-Móri" tells the moving tale of the priest Oddur and his son, who died very young. On a certain winter day the priest rides away from home over a stretch of solid ice, but when the boy sees his father leaving, he runs after horse and rider and, hitting a weak point in the ice, falls through and dies. After the incident the priest slips into deep despair, and his wife-partly because of her own grief and partly because of her husband's despair-divorces him. The tale states that the priest then sends a sending in the form of a dog after his wife for her betrayal. The sending is called a móri, first, (apparently) because it follows the woman's family for nine generations and, second, because it acts typically like a móri. This explanation aside, it seems fairly clear that the móri in this case represents, at least figuratively if not overtly in the narrative, the young boy who was lost beneath the ice. Characteristic of a fetch (in the sense of a soul), the móri in this tale can shift its shape from a dog to a mist, and it seems in keeping with the interpretation that the móri would begin its haunting with the mother who abandoned the beloved father, thus breaking up the family from which he originally came. This again situates the motivation for the haunting in the realm of vengeance, though in this case the father finds himself free of that vengeance since he clearly suffers enough grief at his own hands. Instead, the mother, who is perhaps deemed more worthy of blame because she leaves her husband, becomes the object of the móri's haunting, and for nine generations it serves as a reminder of her mistake. Additionally, here again the móri acts as a more grotesque and even petty remnant of pagan attendant spirits, causing mischief and madness most often. Both of these tales exhibit the vengeful nature of the skotta and móri; the nature of their hauntings and the characteristics of the fylgjur suggest a connection to older concepts of fetches and the aðsókn, while at the same time serving as reminders of the importance of familial and filial faithfulness.

Retribution and punishment are clear themes in Porgarður's narrative as well, for porgarður, who has been condemned to death for a crime and has been wronged by Jón and his wife, Guðrún. Porgarður's retribution must be seen as an ironic twist on the genealogical quality of a family fylgja passed down from generation to generation. The bitter Porgarður responds by cursing the couple with his companionship for nine generations: "Ekki mun hér skilið með okkur; pví ekki er pað meira en fyrir mig að sjá svo um að kveðja mín fylgi ykkur hjónum og ætt ykkar í níunda lið” (We are not done with each other here; because that is not more than for me to see to it that my fylgja will bid farewell to the two of you and your family in the ninth generation). ${ }^{63}$ This may be understood as Porgarður's álag, his curse, in which the word fylgi is most important to the present discussion. Fylgi, a neuter nominative plural noun, is the subject of the verb kveðja, a third person plural with future implication. Thus, Porgarður will not say farewell for nine generations, but the implication of the third person plural noun, fylgi, and the

62 JÁ 1:351.

63 JÁ 1:374. 
plural verb, kveðja (say farewell), implies that it is not just one haunting (Porgarður's) that will carry through the generations but several in succession. In this way, all of the subsequent hauntings of this family fall under Porgarður's álag, not just those stories associated with his name. ${ }^{64}$ Thus, the retribution and punishment in these stories take an unmistakably generational identity.

\section{Final Thoughts: Porgarður, Pejoration, and Angry (Pagan) Spirits}

The folk traditions of the fylgja group discussed here do not have what can be called a "clean" literary or folkloristic heritage, yet it is their dirtiness that makes them interesting as lenses into cultural memory. The changing identities of fylgjur represent the malleability of cultural memories of attendant spirits. In the medieval and postmedieval stories, the identities and classifications of different types of fylgja-be they spirits, personal attendants, farm ghosts, or family ghosts-intermingle. Even in modern Iceland, as Terry Gunnell's work indicates, two distinct types of fylgjur populate Icelandic beliefs-one associated with a family and another associated with a personal spirit ${ }^{65}$-yet all of these types of fylgjur, whether in the medieval, post-medieval, or modern eras, have one common trait: they are attendants (for better or worse). In some cases, even in stories about the same fylgja, the different categories of attendant spirits discussed here seem to become confused or intermixed. For example, in the stories about porgarður, the móri of Sel, later generations were not affected in the same way as their forebears. Porgarður is said to be a móri, which implies more of a physical presence, for the early generations, yet Purídur, of a later generation, is affected by something much more like a psychological disorder, as is Porgerður, who is of an even later generation. Porgarður is clearly a family spirit, as he is called an ættarfylgja (family fylgja). However, the "ghost" that afflicts both Puríður and Porgerður is also said to be an ættarfylgja. It seems possible that this one ættarfylgja is in the cultural memory imprinted upon these stories blending or vacillating back and forth between two different types of fylgja: one that is more spirit than body (in the later generations) and another that is more physical (in the earlier).

While this type of muddling of traditions may create problems for the folkloristic classification of fylgjur, on a functional level, it is nothing but fascinating. The group of tales about these attendant spirits in later Icelandic folklore show signs of their origins. Based on the tales discussed here, there seems to be a connection between Old Norse and post-medieval belief systems, but the connection is more on a functional footing than a morphological one. Understanding this functional connection requires acknowledging that, functionally, the attendant spirits within the Old Norse narratives have been pejorated dramatically throughout the legacy of fylgja tales, yet the differences between the fylgjur of the Old Norse literature and those of the later Icelandic folk tradition

64 Special thanks to Shaun F. D. Hughes for pointing out these important linguistic details.

65 Gunnell, “Modern Legends," 345. 
do not preclude a relationship between them. The similarities between them in fact indicate that the later tales bear a morphological heritage of their predecessors, while both the similarities and the differences between earlier and later narratives can tell us something about the means by which belief developed in Iceland from the pagan era (or at least the early literate era) to the post-Christianization, post-medieval era.

Fylgja stories seem to have been a kind of battleground on which questions of belief were worked out. In the earliest stories, fylgjur are benevolent attendant spirits, but something quickly changes in conversion stories from the medieval period, such that the fylgjur represent the anger of pagan spirits that rages against those who take the new religion. Such anger is not uncommon in Old Norse narratives. The saga about Bárður the god of Snæfellsnes (Bárðar saga Snæfellsáss), as discussed in chapter 1 (42) - shows the staunchly pagan Bárður come back to terrorize his son Gestur, who has converted to Christianity under the influence of King Óláfur Tryggvason. Such, also, is the fate of biðrandi in Piðranda páttr ok Pórhalls (see above, 76). At some point between those medieval stories and the fylgja stories collected by Jón Árnason, fylgjur took on a grotesque, simplistic, and nasty demeanour, perhaps due to the influence of the sending stories so closely related to them, to become something less majestic and mystical than the fylgjur of the pagan past. But the core attributes of the attendant spirit remains: Some fylgjur pass from one generation to the next, and the next; some take on the sense of a spirit, or aðsókn; some offer assistance of a sort; and some, not unlike the nine black riders from Piðranda páttr, execute moral retribution against whomever they deem deserves it. 


\section{Chapter 4}

\section{THE ELF CHURCH: MEMORIES OF CONTESTED SACRED SPACES}

\section{Tungustapi'}

At a farm called Tunga, in Sælingsdalur, there was once a wealthy man with two sons, Arnór and Sveinn, both full of promise but as different from one another as two brothers can be. Arnór was outgoing, brave, and active, while Sveinn was quiet and timid. Arnór was often seen playing with his friends at Tungustapi, the tall, rocky hill near the farm where they lived, while Sveinn spent much of his time in church or walking alone around the same hill when no others were playing there. People would say, in fact, that Sveinn spent so much time there that he must have something to do with the elves who lived in the hill. Sveinn, for his part, warned his brother not to make too much of a ruckus on the hill lest some ill should come of it, but his brother never listened.

One New Year's Eve, Sveinn, as was his wont, disappeared from the farm and no one could find him. Arnór offered to go look for him and walked around the farm until he came to Tungustapi. As he approached the side of the hill that faced the farm, Arnór saw that the rock opened before his eyes and inside the hill stood rows of lamps brightly lit, and he heard music and singing. As he approached the doorway, he saw a great crowd gathered and next to an altar before them stood one dressed in beautiful vestments like a priest. As Arnór crept yet further into the mysterious church, he saw that his brother, Sveinn, was kneeling before the priest at the altar while the priest laid his hands on Sveinn's head. Around them stood others in sacred robes, so Arnór guessed that they were initiating Sveinn into the elf priesthood. Fearing for his brother, Arnór shouted to him that he must come out right away lest he lose his very life. Upon hearing his brother's call, Sveinn turned from the ritual and looked, for a moment, as if he might run toward his brother's call. The elf bishop grew angry, commanded that the door to their church be closed fast, and decreed to Sveinn that, because he had made as if to go to his brother, he was banished and cursed, and that the next time Sveinn saw the elf bishop as he was then, robed and standing at the altar, Sveinn would breathe his last. Then to the elf host he cried:

Ríðum og ríðum
pað rökkvar í hlíðum;
ærum og færum
hinn arma af vegi
svo að hann eigi

Ríðum og ríðum

pað rökkvar í hlíðum;

ærum og færum

svo að hann eigi

\author{
We ride, we ride \\ it grows dark on the slopes; \\ let us drive the poor fellow mad and make him \\ lose his way \\ so that he does not
}

I Adapted from JÁ 1:32-35. “Tungustapi” was collected from Jón Porleifsson (1825-60). 
$\begin{array}{ll}\text { sjái sól á degi, } & \text { see the light of day, } \\ \text { sól á næsta degi. } & \text { the light of another day. }\end{array}$

Arnór ran terrified through the dark night toward his home, but the elf riders caught him and drove him back toward the hill, where their horses at last trampled him until he was all but dead. Having been set free after the elf priest's decree, Sveinn ran back to the farm as fast as he could for help (though without saying what exactly had happened), but no one could find his brother that night. Arnór's near-lifeless body was found the next day by a farmer on his way to the early church service. With his last breath, Arnór told the farmer what had happened and asked that he not be taken back to his home but be left where he lay.

Sveinn was never the same again. He became even more withdrawn and seemed to care nothing for the things of this world. Eventually, he recoiled so much from the world that he became a monk and went to live at the monastery at Helgafell. There, it is said, he became so learned that no one could compare with him, and he sang mass more beautifully than any other in Iceland.

His father, for whom Sveinn cared greatly, lived on at Sælingsdalstunga until he grew old and became quite ill. Perceiving his death was near, he wanted to see his son once more and sent for him. Sveinn came to his father at once, but as he left, he told the others at the monastery that it was likely he would never see them again. He arrived home the Saturday before Easter, and though his father was very near death he asked his son to sing the Easter mass. Reluctantly, Sveinn agreed but on the condition that the doors to the church be firmly closed through the entire service for, he said, his very life depended on it. The next morning the frail old man was taken to the church, where Sveinn, dressed in priestly robes, stood at the altar and beautifully sang the mass. At the end of the service, however, Sveinn turned from the altar and looked out at the congregation to pronounce the benediction. When he did, the doors burst open so that all turned to look out the open doorway only to see the hill, Tungustapi, standing open and facing the church. Inside stood the elf church with its brightly lit lamps leading in a row to the elfish altar. When those in the Christian church turned back toward their own altar, Sveinn had fallen down dead, his father also lay dead beside him. All in attendance knew what had happened, because the farmer who found Arnór's body had shared the story the boy had told him.

Father and son were buried on the same day, and the church at Sælingsdalstunga now stands elsewhere, out of sight of the elf church, whose altar is to the west and whose door is to the east.

The cultural memory embedded within this narrative embodies a series of uncomfortable tensions. The elves are mysterious and powerful, intriguing to anyone who might hear or read the story, yet in the same moment they seem ruthless and vengeful. Arnór may have been dismissive of his brother and perhaps disrespectful to the elves at Tungustapi, but it is difficult to say that he deserves the punishment he receives: left to die slowly on the slopes of Tungustapi through the long, cold New Year's night. The boys' father, too, seems to be an unfortunate casualty, for though he lives out his years, he does so with neither of his sons (their mother is never mentioned) and seems to be caught in the same tragic end as Sveinn. Arnór's brutal death can certainly be connected 
to the folk motif of the Furious Host (a.k.a., The Wild Hunt), E501, which is so pervasive in Indo-European folklore, but recognizing its international origins explains little about what function, in this story, the brutal death serves. ${ }^{2}$ Sveinn's uncommon wisdom and his unnatural ability to sing mass more beautifully than anyone else suggest another peculiarity. His unique gifts work as an odd consolation for the whole affair, yet it is unclear whether the young man is being consoled for the loss of his brother or for the missed opportunity to become an elf priest.

The final words of the story may offer some clarity. It is possible that the story of the elf church at Tungustapi developed to explain why the local church was moved from one location to another. Another Icelandic folk narrative, "Dvergasteinn" (Dwarf Stone), ${ }^{3}$ shares the motif of a church moving from one location to another, which has been shown to have historical corroboration. The tale states that in the twelfth century, a church was moved from the eastern to the western shore of Seyðisfjörður, in eastern Iceland, and archaeological excavations indeed find that a church once stood in both locations. ${ }^{4}$ The 1862 edition of Jón Árnason's collection confirms this notion, as “Tungustapi” in that edition begins by saying that the medieval Icelandic saga Eyrbyggja saga states that a church was moved from one location to another but does not explain why. ${ }^{5}$ The story of "Tungustapi" is meant to provide the lost explanation. Regardless of any historical origins of the church moving, it would appear from these details that some kind of contest between the two sacred spaces-the Christian church and the elf church-is fundamental to the story. On the one side stands the Christian church, which works as a representative of the farm, family, and Christianity, while on the other side, the rocky hill in which the elf church is hidden, which represents elfdom, the otherworld, and a kind of heterodox belief that the leaders of the Church in Iceland had spoken rather strongly against. The monastery at Helgafell acts as a refuge from the fray, but Sveinn cannot be safe there forever: he must return to Sælingsdalstunga to meet his doom. Built upon these spatial images resides a deep cultural memory of sacred and profane spaces passed down throughout the religious history of the country. The roots of Helgafell reach all the way back to the settlement of the country and, as the last chapter of Eyrbyggja saga attests, Sælingsdalur, where Tungustapi is found, is located in a region rich with the

2 Stephen Grundy briefly discusses this connection in Miscellaneous Studies towards the Cult of Óðinn (New Haven: Troth, 2004), 43.

3 JÁ 2:72.

4 For more, see Steinunn Kristjánsdóttir, The Awakening of Christianity in Iceland (Gothenburg: University of Gothenburg, 2004), 95.

5 Jón Árnason, Íslenzkar Pjóđsögur og Æfintýri, 2 vols. (Leipzig: Hinrichs, 1862), 1:31. In the later edition, the comment has been moved to the footnotes, but the commentary is present, though in parentheses, in the manuscript of the collector, Reverend Jón Porleifsson of Ólafsvellir (Lbs. 531 4to, 63r.). The account in Eyrbyggja saga refers to the church moving as it pertains to the burial place of Snorri goði Porgrímsson (963-1031), who is said to have been buried at the church in Sælingsdalstunga and moved to the new location when the church was moved. See Eyrbyggja saga: Brands páttr orva, Eiríks saga rauða, Grœelendinga saga, Gronlendinga páttr, ed. Einar Ólafur Sveinsson and Matthías pórðarson, Íslenzk Fornrit 4 (Reykjavík: Hið Íslenska Fornritafélag, 1935), 183-84. 
history of the original settlers. Throughout the long history of these important places, contests of sacred and profane spaces, not unlike the one observed in the folk story "Tungustapi," are woven into the cultural memory of the land.

If "Tungustapi" is a story of contested sacred spaces, then the Christian church must certainly be said to have "lost" that contest: three people are dead, and the Christian church must be moved to another location to escape the threat of the elf church. The deeper question most relevant to the present study is, why does the Christian church lose? At the very least, we must try to understand the purpose or function that such an apparent defeat might serve within the cultural memory of belief in the country. To pursue an answer to these questions, the present chapter must go back to the earliest examples of a cultural memory of space in Iceland, even to the origins of the country's settlement, to examine how memories of contested sacred spaces have changed from the earliest narratives to the time in which the story of "Tungustapi" was current.

\section{Early Memories of Contested Spaces}

The first textual evidence of cultural memories of sacred space originate in the eleventh and twelfth centuries but reach back to the settlement period of Iceland during the settlement period (roughly 874-930), at which time it was the work of settlers to set apart spaces not only as inhabitable but also as sacred. Consequently, many of those memories of space in Iceland are of a contest not between respective religious belief systems but between one belief system and the wilderness of an untamed land. Accounts from Landnámabók (The Book of Settlements) ${ }^{6}$ and the later Eyrbyggja saga offer accounts of settlers taking possession of land by carrying fire around its perimeter, ${ }^{7}$ and stories of the construction of houses in Iceland and in Scandinavia more broadly, in which the house itself becomes a microcosm, and the ondvegissúlurnar, the high-seat pillars, serve to connect the space of the abode with the mythic cosmos. ${ }^{8}$

\footnotetext{
6 The dating of Landnámabók is difficult to fix. Its earliest extant version is from the second half of the thirteenth century but is perhaps a copy of an earlier version. For a discussion of the origins of Landnámabók see Jón Jóhannesson, Gerðir Landnámabókar (Reykjavík: Hið íslenzka bókmenntafélag, 1941); Íslendingabók. Landnámabók, ed. Jakob Benediktsson, Íslenzk Fornrit 1 (Reykjavík: Hið Íslenska Fornritafélag, 1986); Barði Guðmundsson, "Uppruni Landnámabókar," Skírnir 112 (1938): 5-22; Sveinbjörn Rafnsson, Studier í Landnámabók. Kritiska Bidrag till den Isländska Fristatstidens Historia, Bibliotheca Historica Lundensis 31 (Lund: Gleerup, 1974); Jón Hnefill Aðalsteinsson, Under the Cloak: A Pagan Ritual Turning Point in the Conversion of Iceland, 2nd ed. (Reykjavík: Háskólaútgáfan, 1999).
}

7 Eyrbyggja saga, 8. Mircea Eliade notes that this practice might resonate with the Vedic practice of legally claiming land by a fire ritual, and other sagas speak of similar rituals. See Eliade, The Sacred and the Profane: The Nature of Religion, trans. Willard R. Trask (New York: Harcourt, 1987), 30-31. See also Dag Strömbäck, "Att helga land. Studier i Landnáma och det äldsta rituella besittningstagandet," in Festskrift tillägnad Axel Hägerström (Stockholm: Almqvist and Wiksell, 1928), 198-220.

8 Eliade uses the example of the Vedic ritual for claiming possession of land, in which "possession becomes legally valid through the erection of a fire altar," a ritual that both becomes the organizing 
Later, in places where pagan and Christian belief systems interacted, nonhomogeneous space became a currency of religious beliefs. Íslendingabók, by Ari fróði (the wise) Porgilsson (1067-1148), and Landnámabók offer well-known references to Christian monks in Iceland prior to the coming of Nordic settlers. Íslendingabók states that when the first travellers came to Iceland, Irish monks lived there:

Pá váru hér menn kristnir, peir es Norðmenn kalla Papa, en peir fóru síðan á braut, af pví at peir vildu eigi vesa hér við heiðna menn, ok létu eftir bækr írskar ok bjollur ok bagla. Af pví mátti skilja, at peir váru menn írskir. ${ }^{9}$

There were Christians here then, whom the Norwegians called Papar, but they then left because they did not want to be here with pagan people, and they left behind Irish books, bells, and crosiers. Thus it can be surmised that they were Irish men.

Scholars are dubious of the historical validity of this account, ${ }^{10}$ mainly because no archaeological evidence has been found to support Ari's claim, ${ }^{11}$ but regardless of the historical validity of the account, the passage indicates something about how the settlement was perceived by Icelanders in Ari's time. Namely, the cultural memory of space here validates the country's contemporary dedication to Christianity: if Christian monks were there before pagans, the logic says, then the country "belonged" to Christ even before it belonged to (pagan) Norsemen. In contrast with this Christian-dominant cultural memory, accounts of landvættir (land "wights" or land spirits) in Iceland

principle for the land and reproduces a microcosmic Creation for the settler. On the other hand, the same can be said of the construction of a house, where "the threshold divides the two sorts of space [sacred and profane]. ... The central pillar in the dwellings of the primitive peoples ... is likened to the cosmic axis." The house, then, becomes itself a symbolic microcosmic sacred space, set apart from the outside, profane world through with an individual must travel to reach the centre, the organizing principle of existence. Mircea Eliade, Patterns in Comparative Religion, trans. Rosemary Sheed (Lincoln: University of Nebraska Press, 1996), 379. See also Terry Gunnell, "Hof, Halls, Goðar and Dwarves: An Examination of the Ritual Space in Pagan Icelandic Hall," Cosmos 17 (2001): 3-36.

\section{9 Íslendingabók, 5. A similar passage occurs in Landnámabók, 31-32.}

10 Jenny Jochens notes the need for caution as well, but she leans toward accepting the account. To this end she argues that "with one exception all medieval sources that treat conversion repeat these words, Ari's reputation for reliability and the fact that five Icelandic place-names incorporate the word papi (priest or monk) have encouraged its general acceptance." See "Late and Peaceful: Iceland's Conversion Through Arbitration in 1000," Speculum 74 (1999): 621-55 at 633. Jochens notes also that Ari's claim is "further corroborated by the contemporary Latin writer Dicuilus, an Irish monk at the Carolingian court, who wrote a book entitled Liber de mensura orbis terrae in 825." In Um Haf Innan: Vestrænir menn og Ízlensk Menning á Miðöldum (Reykjavík: Háskólaútgáfan, 1997), however, Helgi Guðmundsson suggests that Ari's account here may be based on that of the Irish monk Dicuilus and is therefore unreliable. See also Gísli Sigurðsson, Review of Um Haf Innan: Vestrænir menn og Ízlensk Menning á Miðöldum by Helgi Guðmundsson, Alvissmál 9 (1999): 111, where Gísli criticizes Helgi's methodology and general theory.

I I Between 1967 and 1981, Kristján Eldjárn carried out excavations at Papey, where the monks were said to have been, but he found no indication of their presence. See "Papey. Fornleifarannsóknir 1967-1981," Árbók hins Íslenzka Fornleifafélags (1988): 35-188. 
date back to early memories of the settlement as well. ${ }^{12}$ Landnámabók indicates that, according to law, settlers had to be careful not to scare away ${ }^{13}$ the landvættir who inhabited the land when Norsemen first arrived.

Also in Landnámabók, a rather different kind of contested space is found in the story Ásólfur, a Christian settler who was so devout that he would not even eat the food of the pagan men. ${ }^{14}$ Ásólfur is said to have lived in Ósar and kept to himself though he seemed to others to have an uncommon wealth of supplies and stores. His neighbours, who were of course pagan, began to wonder how he got his food and discovered that the stream by his house was brimming with salmon. Envious, they drove Ásólfur away and took over the stream, which subsequently failed to yield any salmon at all. When Ásólfur's good fortune continued at his subsequent homes, his neighbours chased him away a second and a third time (from Miðskála and then from Ásólfsskála). Finally, one of Ásólfur's kinsman, Jorundar, set him up with a house and food at Hólmi, where he lived out the rest of his life. After Ásólfur died, he was celebrated: "stendr par nú kirkja, sem leiði hans er, ok er hann enn helgasti maðr kallaðr" (a church now stands there where he lies, and now he is called the holiest of men). ${ }^{15}$ In a way similar to "Tungustapi" and "Dvergasteinn," this account offers an explanation of the specific location of a Christian church in a way that relies upon the notion of contested spaces. It is worth noting, however, that the sacredness of all of these spaces does not depend upon any inherent quality. There is nothing special about any of Ásólfur's settlements until he gets there, and after he leaves, the land returns to the ordinary. Ásólfur's holiness sets apart from ordinary space the rivers (and eventually the ground upon which the church was built).

Another well-known early cultural memory of sacred space occurs in the story of Auður djúpúðga (the deep-minded) Ketilsdóttir. Here, a certain sacred space is transferred from one system of belief to another. Although the religious connotations of that sacred object may have changed, its potency remains alive in the logic of beliefs of the people. When Auður comes to Iceland from the British Isles, where she became a dedicated Christian, "hon hafði bænahald sitt á Krosshólum; par lét hon reisa krossa, pví at hon var skírð ok vel trúuð” (she said her prayers at Cross Hills; there she raised crosses because she was baptized and a true believer [trúuð]). ${ }^{16}$ After Auður dies, his pagan kinsmen retain a belief in the hills, though they transform it into something different:

12 For a recent discussion of this and other references to landvættir, see Nicholas Meylan, "La (re) conversion des 'Esprits de la Terre' dans l'Islande Médiévale," Revue de l'Histoire des religions 230 (2013): 333-54.

13 Landnámabók (H268), 313.

14 This story also appears in chapter 127 of Óláfs saga Tryggvasonar en mesta, ed. Ólafur Halldórsson, 3 vols. Editiones Arnamagnæanæ (Copenhagen: Munksgaard, 1958), 1:276-78.

15 Landnámabók (H 21), 64.

16 Landnámabók, 139. 
par họfðu frændr hennar síðan átrúnað mikinn á hólana. Var [par] pá gọr họrg, er blót tóku til; trúðu peir bví, at peir dæi í hólana. ${ }^{17}$

Her kinsmen later held a great belief in the hills. They made a pagan altar there where sacrifices took place; they believed therefore that they would go into the hills upon death.

A transformation of the sacred space from Christian to pagan takes place, apparently, with no difficulty. It is not clear whether the original Christian sacredness of the hills requires some kind of ritual repurposing although the raising of a pagan altar may be telling. Regardless, the original Christian character of the hills does not impede the space being taken over by pagan devotees: there were no supernatural repercussions against the pagans for doing so. This signals an apparent shift in the cultural memory of the space, so that its hierophanic nature remains constant even after Auður's kinsmen take it over. In fact, the hills possess their sacred potency for Auður's kinsmen because they were sacred to Auður, not in spite of that fact. The same is not true in the opposite direction, since Auður will not allow herself to be buried on pagan land. In accordance with her wishes, she is buried by the sea between the high and low tide marks, rather than in unconsecrated ground. For both the pagan ancestors and for Auður, the sacredness of their respective kin carries over, but for Auður, the pagan space cannot be tolerated after death. The land between the high and low water mark is no more hallowed than any dry land in Iceland, but because her burial plot is owned by the sea (and because it receives a daily "baptism" when the tide comes in), she finds it acceptable.

Beyond Landnámabók and Íslendingabók, the Icelandic cultural memory of contested sacred space continued to develop in the thirteenth-century Icelandic saga Eyrbyggja saga. In addition to the account mentioned above about claiming a settlement by fire, memories of sacred space appear in the description of the settlement of Pórólfur Móstrarskegg on Snæfellsnes. ${ }^{18}$ When Pórólfur's ship first approaches Breiðafjörður (which Pórólfur himself is said to have named), he casts overboard the ondvegissúlurnar, the high-seat pillars - which he had taken with him from his temple in Norway-and resolved to settle wherever they landed. When they come to shore, he finds the place where the pillars landed and establishes a temple (hof) at Hofsstaðir, the structure of which Terry Gunnell, among others, has suggested reflects the pagan cosmos. ${ }^{19}$ But

\section{Landnámabók (H 81), 137-38.}

18 Helgafell is among the first plots of ground set apart as in some way sacred, but it certainly was not the only one. Other natural spaces set apart by ritual, proclamation, or consensus include those under álög (a spell) or bannhelgi (taboo). Árni Óla has catalogued many of these sites in Iceland: see Álög og Bannhelgi for more examples of this kind.

19 See Gunnell, "Hof," 3-36. See also Frands Herschend, Livet i Hallen: Tre fallstudier i den yngre järnålderns aristokrati, Occasional Papers in Archaeology 14 (Uppsala: Institutionen för akeologi och antik historia, Uppsala universitet, 1997), 49-55; Frands Herschend, "Ordering Landscapes," in Settlement and Landscape, ed. Charlotte Fabech and Jytte Ringtved, Jysk Arkeologisk Selskab (Århus: Jutland Archaeological Society, 1999), 334; Charlotte Fabech's "Centrality in Sites and Landscapes," in Settlements and Landscape: Proceedings of a Conference in Århus, Denmark, May 4-7, 1998 (Århus: Jysk Arkeologisk Selsk), 458. These suggest that the farm serves as a central 
equally important is the way the structure relates to itself and the world around it. The hof is separated into at least two spaces that differ qualitatively. The ondvegissúlurnar function as the threshold between the two spaces, and all the space beyond them is considered sacred: “líking sem nú er sǫnghús í kirkjum, ok stóð par stalli á miðju gólfinu sem altari" (just as the choir is in churches now, and there stood a [pagan] altar in the middle of the floor like the [Christian] altar). ${ }^{20}$ Into the high-seat pillars are driven the reginnaglar, the sacred nails, which consecrate the threshold. ${ }^{21}$

Regardless of whether post-conversion accounts of pre-conversion sacred spaces were accurate representations of history, two points may be extracted from these texts. First, while post-conversion writers viewed pre-Christian sacred spaces through the lens of Christianity, the semantic fields for pre- and post-Christian spaces remained distinct in the texts they composed. The hof (temple), as it is described in Eyrbyggja saga, though similar, is not a kirkja (church), with which it is compared, and the stalli (pagan altar), though similarly situated, is not an altari (Christian altar), with which it is compared. The author distinguishes the pre-Christian belief system by preserving a lexical field sufficiently removed from mainstream contemporary religious culture, and he feels comfortable enough with the separate fields to use the one as a comparison of the other. One belief system (the Christian) predominates in the minds of the author and the anticipated audience so much that it can be used a descriptive point of reference. In other words, the cultural memory of the thirteenth century had sufficiently distinguished pagan sacred space from Christian sacred space that the author of Eyrbyggja saga felt no need to comment further on what constituted orthodox (Christian) sacred space and what constituted heterodox (pagan) space. Second, there is no sense of pejoration evident in these descriptions, as was the case with the Dead Bridegroom tale type discussed in chapter 1 of this book. The difference between the respective sacred spaces seems to have been clear enough already, so that Pórólfur's temple (as described in Eyrbyggja saga) remains free of any negative or demonizing connotation. (This would change as memories of sacred spaces proceed through history.)

Pórólfur also identifies two other sites as sacred: Helgafell (the Holy Mountain) stood at the heart of the entire area and commanded a long view of the landscape and fjord. Similar to Auður's kinsmen, Pórólfur and his companions believed they would go into Helgafell after they died. He also established a ping (assembly) at the headlands

point of the cosmos, much in keeping with Eliade's view. To my mind, there remains the question of the extent to which these comparisons represent a symbolic cosmos versus a mythical one. Symbolic differs from mythical in that the former merely represents a place in which a mythic experience can take place, where the latter is a place reserved for the mythic experience. On the more general scale of methodology, the current study will speak indirectly to questions such as these, aiming to point out the general distinction between concepts such as these in the logic of belief for a mythic structure.

20 Eyrbyggja saga, 8.

2I Gunnell notes six passages in Landnámabók in which these are used. See "Hof," 15; see also Landnámabók, 42-45, 124-25, 232, 302, 312, 317, and 371. 
where the pillars came to shore. The latter site was deemed so sacred by Pórólfur that no bloodshed could occur on it and no one could relieve themselves there. Instead, anyone who attended the assembly on that plot of land had to walk out to the "dritsker," the "shit" skerry. ${ }^{22}$ During one assembly meeting, a visiting group flouted the edict not to relieve themselves on the sacred land, and a bloody battled ensued. After that time, the land was deemed "eigi helgari en aðra" (no more sacred than any other), ${ }^{23}$ and the assembly was then moved to a different location.

The four sites described in this episode of Eyrbyggja saga-the hof, Helgafell, the original ping site in a field near the hof (at Hofsstaðir), and the second bing site-share some noticeable connections to the story of "Tungustapi." It is to a Christian monastery at Helgafell-that same pagan "holy mountain" at the heart of the landscape in Eyrbyggja saga - that Sveinn retreats in order to escape the curse of the elfin bishop, and the ping site in particular holds a special relevance to the folktale "Tungustapi." This episode also describes one of the first times a sacred space is moved in Iceland, though here a pagan assembly site, due to an offence perpetrated at the original site, not unlike the moving of the church in "Tungustapi." Arnór offended the elves in "Tungustapi" while the visiting group offend the "sacredness" of the ping site in Eyrbyggja saga. Interestingly, the verb used for relieving one's self in the Eyrbyggja saga's account is álfrek ganga, a euphemism for defecation which literally means "the driving away of the elves." Connections between the two stories need not be overdone, yet it is at least worth noting that the same mechanisms of contested spaces - the moving of sacred space and the motivations behind those moves-are evident in both medieval and post-medieval sources.

\section{Foundations of Sacred Spaces}

Scholars are diligent in pointing out that these descriptions of pre-Christian pagan sacred spaces are not reliable because the medieval (Christian) writers who composed these texts were doing so long after conversion. Certainly, this point cannot be ignored. Whatever the pagan origins of these sacred spaces may have been, descriptions of both Christian and pagan sacred spaces-written as they were by Christians writers-build upon a Judeo-Christian belief system that has always placed a priority on sacred space. ${ }^{24}$ In the Pentateuch, God's instructions on building the Ark of the Covenant and the Tabernacle highlight the point. God says to Moses that the Israelites "shall make me a sanctuary, and I will dwell in the midst of them." ${ }^{25}$ God's instructions on the construction

22 These details are described in chap. 4 of Eyrbyggja saga, 7-10.

23 Kevin J. Wanner explores the importance of this passage in "Purity and Danger in Earliest Iceland: Excrement, Blood, Sacred Space, and Society in Eyrbyggja Saga," Viking and Medieval Scandinavia 5 (2009): 213-50. I will return to this scholarly discussion directly.

24 This changes somewhat with the Reformation, as I will discuss below (108-13).

25 Translated from the Vulgate, Exodus 25:8: facientque mihi sanctuarium et habitabo in medio eorum. 
of the Ark and the Tabernacle ${ }^{26}$ are remarkably specific, describing types of materials, dimensions, the colours of the veils, and procedures for sanctification. The Tabernacle became the heart of the Israelite religious experience-a physical space into which only the most purified of priests may enter, ${ }^{27}$ a place in which dwelt the spirit of $\mathrm{God}^{28}$ and through which God communicated his commands and delivered forgiveness of wrongdoings. ${ }^{29}$ But the physical space of the Tabernacle was symbolically disrupted in the minds of the Christian faithful. The Gospels of Matthew, Mark, and Luke say that the heavy veil dividing the holy inner sanctum of the Tabernacle was torn into two pieces. ${ }^{30}$ The divide between human and divine was thus broken, and the body of Christ, rather than the sanctified space, became the medium through which communion with God might be attained. Through the sacrament of the Eucharist (the ingestion of Christ's body and blood), God now dwelt not in the Tabernacle but within the bodies of all who partook. The physical body, just as Christ's, becomes the temple of God. ${ }^{31}$ In medieval Europe, Christ's physical posture upon the cross subsequently becomes a template for designing sacred spaces, which often took as their floor plan the shape of the cross. ${ }^{32}$ The body of Christ took the place of the Tabernacle by way of the Eucharist and in the reproduction of his crucifixion in the design of many medieval churches, while the bodies of the most holy saints held sanctifying power in the form of holy relics. Thus, in perhaps a mystical but yet a very real way, then, the agent of the cultural memory (the believing person) becomes also the object of the cultural memory (the sacred space). This internal situation is then confirmed by an external duplication of it-i.e., the church in the shape of a cross, the holy relics, and the ritual ingestion of the Eucharist. There, the actual, external spaces function both as actual, hierophanic spaces and as representations of the internal sacred space of the human person, whose body, upon initiation into the religion, is elevated to the status of a sacred space as the temple of God.

This Judeo-Christian view of sacred space contributes something to the vocabulary used by the medieval writers, even when they describe pagan sacred spaces, but differences between the memories of sacred space in pagan and Christian Iceland prove relevant. Kevin J. Wanner, who has recently worked on the sacred space in medieval Icelandic sources, applies Mary Douglas's theory of social organization to Icelandic texts in

26 Jonathan Z. Smith's discussion of the Jewish Tabernacle bears the most relevance to the current discussion. See especially "To Put into Place," in To Take Place: Toward Theory in Ritual (Chicago: University of Chicago Press, 1987), 47-73, where Smith adeptly articulates the mapping of the Tabernacle and the relation of Israelites and priest to it.

27 Leviticus 16:3-6.

28 Exodus 25:8.

29 Leviticus 16:15-16.

30 Matthew 27:51; Mark 15:38; Luke 23:45.

3I 1 Corinthians 6:19; 3:16-17.

32 See Dawn Marie Hayes, Body and Sacred Place in Medieval Europe, 1100-1389, Studies in Medieval History and Culture 18 (New York: Routledge, 2003), especially 95-98. 
order to understand something about the uses of sacred space in early Iceland. ${ }^{33}$ Wanner's assessment is thought-provoking, but one question lingers in the final stages of his analysis, specifically regarding the changing status of a sacred space that has been (or that might be) defiled in some way. Wanner draws a connection between the prohibitions against bloodshed on sacred ground in Eyrbyggja saga and similar prohibitions in Christian law codes of the thirteenth-century Nordic world.$^{34}$ He begins by referring to a well-known scene in Eyrbyggja saga, chapter 10 (mentioned above, 97), in which the sacred land has been defiled by the bloodshed from a battle that was, not insignificantly, fought over the sacredness of the land itself. After the battle, the text declares the once-sacred land to be "eigi helgari en aðra" (not more holy than any other). ${ }^{35}$ In Christian law codes, says Wanner, "blood spilled in violence is accorded the same status and is thought to have the same effect on hallowed ground ... as in Eyrbyggja saga." ${ }^{36}$ According to Wanner, then, the Nordic Christian perception of defiled sacred space matches the pagan perception of defiled sacred space: the space simply no longer qualifies as sacred; it is merely "eigi helgari en aðra."

This point may be worth further consideration in light of the manner in which sacred Christian space (either a church or a churchyard) is redeemed as a fully functional sacred space after having been defiled in some way. Two important Christian law codes of the time-the Frostaping and Christenret of Archbishop Jon of Nidaros-describe the rechristening of defiled sacred spaces. The Frostaping says that when hostilities disturb the peace of a church, "En fe pess er uigh uakte skal fara til kirkiu vigslu fyr en i konungs garð falle eða biskups" (The goods of the one who stirred up the fight shall go to consecrating the church before it goes to the treasury of the king or bishop); ${ }^{37}$ and the Christenret says that when blood is shed in a church or churchyard, "pa ma æigi syngia i pairri kyrkiu. hvart sem honn hevir verit vigð eða uvigð. fyr en byskup hevir ræinsat með vigðu vatne" (then no one may conduct services in the church, whether it has been consecrated or not consecrated, until the bishop has purified it with holy water). ${ }^{38}$ No similar stipulation exists for the defiled pagan sacred space in Eyrbyggja saga. The difference, though perhaps subtle, is an important one. ${ }^{39}$ For Pórólfur's sacred land to

33 Wanner, "Purity and Danger." See Wanner's literature review for more detail on earlier efforts to understand Helgafell. See also Mary Douglas, Natural Symbols: Explorations in Cosmology (New York: Routledge, 2003 [1970]).

34 Wanner refers to Gulaping, Frostaping, and kristenréttr. See Wanner, "Purity and Danger," 241-42. For original quotations from Frostaping, see Keyser and Munch, Norges gamle love indtil 1387, vol. 1 (Oslo: Gröndahl, 1846), 134; and for "Erkebiskop Jons Cristenret," see Keyser and Munch, Norges gamle love, 2:343.

35 Eyrbyggja saga, 17.

36 Wanner, "Purity and Danger," 242.

37 Keyser and Munch, Norges gamle love, 1:134.

38 Keyser and Munch, Norges gamle love, 2:347; my italics. Also quoted in Wanner, "Purity and Danger," 242.

39 This detail, while important to my discussion, detracts little from Wanner's overall argument. 
lose its sacredness indicates that something has abandoned it. It would seem that the bloodshed in the battle has scared away the spirits that indwelled within the sacred space, in keeping with the notion of álfrek ganga, or "driving away the elves" ${ }^{40}$ through the contamination of a sacred space. Without these supernatural beings, who appear to leave forever, the formerly sacred space is indeed mere space like any other (that is, "eigi helgari en aðra"). In contrast, the defiled Christian sacred space falls under something more like a taint or stain of which it must be cleaned. Even the verb used in the Christenret passage indicates as much: the space must be ræinsat, purified or cleansed-“rinsed," as the word would become in English. The sacred space endured and was cleansed of its taint rather than the sacredness being driven out of it. The distinction is subtle but significant when considering the longer view of religious development in Iceland, which incorporates, as will soon be demonstrated, contests between Catholic and Protestant spaces into the notion of defiled sacred space.

Complex though this legacy of sacred space may have been, its importance was not lost on the medieval Icelandic Christian world. Sverrir Jakobsson draws attention to "the complex ways in which time and space had a social meaning in thirteenth-century Iceland-and how the Church had succeeded in imposing a religious interpretation on these underlying frameworks of the world-view." ${ }^{11}$ Throughout medieval Christendom, the medieval church promoted ideas about sacredness and sacred space, but it also allowed for those specific ideas to develop in variant forms according to region and custom. In Iceland, for example, space is made holy through the blessing of springs and pools of water (like those blessed by Bishop Guðmundur Arason), ${ }^{42}$ the establishing of holy sees at Skalhólt and Hólar, the raising of local churches and monasteries throughout the island during Christianization, the distribution of holy relics at various places in the country, and the protection and asylum afforded by churches and churchyards. All this was challenged during the struggles over the Reformation in Iceland, as can be discerned, first, by the Danish bailiff Didrich von Minden's hostile takeover of monasteries, and, second, Daði Guðmundsson's disregard for the sanctuary of a church when he finally captures Jón Arason and his sons on the eve of Reformation in Iceland.

\section{Contested Spaces and the Reformation}

The study of contested spaces thus far has identified three types of contests in the medieval sources:

40 Wanner, "Purity and Danger," 216 and 217. I agree with Wanner that álf- in this word ought to be considered something more like landvættir (land spirits), rather than elves as we think of them today. See "Purity and Danger," 216.

4I Sverrir Jakobsson, "Heaven is a Place on Earth: Church and Sacred Space in Thirteenth Century Iceland," Scandinavian Studies 82 (2010): 1-20 at 2.

42 For a thorough discussion of the cult of Guðmundr Arason, see Joanna A. Skórzewska, Constructing a Cult: The Life and Veneration of Guðmundr Arason (1161-1237) in the Icelandic Written Sources (Leiden: Brill, 2011). 
1. Contests between Christian and pagan spaces, manifested primarily in accounts of the settlement of Iceland;

2. contests within (Christian) accounts of pagan spaces that have been defiled and from which the sacredness has gone;

3. contests between Christian sacred spaces and defiled sacred spaces that must be cleansed, as indicated in the discussion of Christian legal codes.

These early accounts of sacred, profane, and defiled spaces, whether pagan or Christian, create a context for cultural memories of contested spaces in Iceland as the systems of belief develop in the country over time. It is especially important here to note the value of the settlement period-and accounts of it in Íslendingabók and Landnámabókto the Icelandic cultural memory. As Kevin P. Smith puts it, "the settlement of Iceland has provided Icelanders with an important ideological charter for eight centuries. Íslendingabók formalized the identity of the Icelanders as a distinct people with a unique, known history ... By the thirteenth century, when the earliest extant version of Landnámabók was written, the tales of Iceland's settlement retained this function." ${ }^{43}$ These conclusions may easily be applied to cultural memories of contested spaces in Iceland. Memories of these important landscapes were thus sustained throughout the Reformation period in Iceland and became vital parts of the folk narratives collected in the nineteenth century. While some references to sacred space at times contributed not much more than narrative context, a significant portion also used space as a means of preserving or comprehending some aspect of social conditions. For example, alongside religious history, post-Reformation folklore often became a mechanism by which positive and negative cultural memories of the Catholic ecclesia were formulated. Helgafell continued to play a prominent role in that cultural memory, as may be seen in the tale entitled "Helgafellsklaustur" (The Cloister at Helgafell), ${ }^{44}$ which offers an incriminating explanation of how the mountain pass dubbed Munkaskarð (Monks' pass) received its name. When, during the Reformation, the monastery at Helgafell was dissolved, the expelled monks "litið aftur úr skarði pessu heim til staðarins og klaustursins og bannfært hvorttveggja með sungnum ${ }^{45}$ sálmum” (looked back from this mountain pass to the land and the monastery and excommunicated both with the singing of psalms). ${ }^{46}$ The tale should certainly call to mind the violence perpetrated against Catholics in Iceland at the hands of the Danish bailiff, Didrich von Minden, leading up to the Reformation in Iceland, but the means by which they excommunicated the lands and the monastery, ${ }^{47}$ by

43 Kevin P. Smith, "Landnám: The Settlement of Iceland in Archaeological and Historical Perspective," World Archaeology 26 (1995): 339.

44 JÁ 2:75-76.

45 The monks "bannsyngja." That is, they perform excommunication by song. Consider also a similar place called Sönghóll near Kirkjubær.

46 JÁ 2:76.

47 For more on this topic, see Cormack, "Catholic Saints." 
the singing of psalms, will be relevant in the subsequent discussion of a certain sorcerer, Galdra-Loftur, who uses a twisted version of singing to defile a Christian sacred space.

Concerning sacred and profane space in the narrative of "Helgafellsklaustur," several points are of interest. For one, the monks carry out their excommunication from the mountain pass, as far from the monastery as they can get while still being able to see it; ${ }^{48}$ they conduct a ritual to effect the transformation of the space; they also excommunicate both the cloister (klaustursins) and the surrounding land (staðarins), making the action applicable not only to the once-sacred space but also to whom- or whatever might inhabit it. In short, the curse affects humans, livestock, and wild animals alike. In other words, not just the cloister but the constituents, too, are subject to the monks' excommunication. Most significantly, the excommunication, a gesture typically reserved for a person or peoples (in a few cases), reverts what was once sacred space into something outside of Christendom. The land still cannot be called "eigi helgari en aðra," but neither is it merely defiled, as when violence or bloodshed has occurred. Excommunication permanently fixes the space outside of Christendom. While we are not yet at the point where an evil ritual transforms sacred space into a force for evil (as will soon be the case with a certain evil Icelandic magician named Loftur), we do observe a ritual transformation of space. This space has become corrupted, profaned with sinfulness; it is therefore condemned, as are the people who live there.

Stories have also grown up around two other cloisters near Kirkjubær in the southeast of Iceland and cast Catholicism in quite a negative moral light. The cloister at Kirkjubær housed nuns while another at nearby Pykkvabær, just over a mile away, was home to a community of monks, which proximity makes for some interesting anecdotes about monk-nun relations. Many of the tales about Kirkjubær and Pykkvabær contribute typical anti-Catholic incriminations that describe immoral behaviour of monks and nuns together. Among these narratives we find the popular international tale ${ }^{49}$ in which the abbess of Kirkjubær Cloister finds a monk and a nun in bed together and prepares to chastise them appropriately, when the nun notices something clinging to the abbess's coif: the underpants of the abbot from Pykkvabær. "Allar erum vér syndugar, systur" (We are all sinners, sister), ${ }^{50}$ says the abbess. Stories like this one, while common in international collections, contribute a jocular post-Reformation perspective of Catholicism and perhaps ought not be considered as much more than propaganda or possibly an expression of rivalry. They also, however, correspond to the feeling in postReformation ecclesiastical culture that Catholic Iceland maintained only a thin veil of moral standards.

Other tales assume a more expressly Icelandic identity. For instance, the large freestanding rocky outcrop called Systrastapi at Kirkjubær Cloister is the subject of

48 Special thanks to Margaret Cormack for pointing out this detail.

49 As Einar Ólafur Sveinsson notes, in Folk-Stories of Iceland, 280, this common story occurs most visibly in the Decameron.

50 JÁ 2:78. 
an extended story about one or possibly two nuns (sisters) who were burned for illicit behaviour. One, named Katrín, was accused of making pacts with the Devil, defiling the Eucharist, and sleeping with a number of laymen, while the other (unnamed) had either insulted the pope or not thought enough of him. ${ }^{51}$ The sisters were reported to have been burned at Systrastapi, where there can be seen two tufts of grass, one that remains evergreen and another that never turns green and produces only thorns. ${ }^{52}$ Yet another story about Kirkjubær reaches as far back as the settlement period in Iceland. Ketill fiflski (the foolish), one of the few Christians among the first settlers in Iceland, is said to have settled at Kirkjubær, and it was said then that only Christians could inhabit the land. After Ketill's death, a pagan, Hildir, tried to move to the area, but the moment he crossed the tungarðr, the border or fence around the area, he dropped dead and was buried at a place called Hildishaug. ${ }^{53}$

\section{Galdra-Loftur and the Battle for Sacred Space ${ }^{54}$}

After the Reformation had taken hold, contests over sacred spaces at times took a dark and serious turn in certain corners of Icelandic folklore, as is evident in the classic folktale "Galdra-Loftur" (Loftur the Magician). Not much is recorded about the historical Loftur Porsteinsson, except that he was born shortly after 1700 and matriculated at the Hólar Cathedral School. ${ }^{55}$ The folk motifs associated with Galdra-Loftur are rooted in the

\section{I JÁ 2:77.}

52 In fact, it is safe to say that not one corner of the Icelandic landscape is homogeneous. Rocks, shorelines, hills, rivers, fields, glaciers, volcanoes, and whatever else are all likely candidates to be set apart as sacred or enchanted. Some of these spaces may be classified as álagablettir, "enchanted spots," and some have legacies that reach far back into the Icelandic cultural memory. Many álagablettir have been catalogued and described in Árni Óla’s Álög og Bannhelgi, and recent work by Terry Gunnell has considered them in light of comparable migratory legends from Norway, Ireland, and the Northern Islands of the United Kingdom. Tungustapi would be better classified as an álfakletta (elf-crag), as described by Valdimar Tr. Hafstein, "The Elves' Point of View: Cultural Identity in Contemporary Icelandic Elf-Traditions," Fabula 41 (2000): 87-104. See Terry Gunnell, "Kraftur, staðarins: Íslenskar sagnir um álagabletti í samanburði við erlendar sagnir," in Rannsóknir í félagsvísindum XIII. Erindi flutt á ráðstefnu í október 2012, ed. Sveinn Eggertsson and Ása G. Ásgeirsdóttir (Reykjavík: Félagsvísindastofnun Háskóla Íslands, 2012); Terry Gunnell, "The Power in the Place: Icelandic Álagabettir Legends in a Comparative Context," in Storied and Supernatural Places: Studies in Spatial and Social Dimensions of Folklore and Sagas, ed. Ülo Valk and Daniel Sävborg, Studia Fennica Folkloristica 23 (Helsinki: Finnish Literature Society/SKS, 2018), 27-41. See also Jón Árnason's treatment of álagablettir in JÁ 1:457-67.

53 The editor of these tales must have taken this account at least in part from a version of Landnámabók. The place names, at least, must have had a resilient and wide distribution. See Árni Óla's Álög og Bannhelgi, 179-80 and Einar Ól. Sveinsson, Landnám í Skaftafellspingi (Reykjavík: Skaftfellingafélagið, 1948), 97.

54 Note Einar's lengthy discussion of Galdra-Loftur and its sources (Einar Ólafur Sveinsson, Folk-Stories of Iceland, 206-13).

55 Einar Ólafur Sveinsson, Folk-Stories of Iceland, 207. 
stories of Sæmundur fróði (the wise) Sigfússon, who will be discussed in full detail in the next chapter, but Galdra-Loftur seems to have captivated the Icelandic imagination even more than Sæmundur in the modern era. The fascination with Galdra-Loftur is due in no small part to the efforts of Skúli Gíslason, ${ }^{56}$ who edited and added a literary quality to existing accounts of Loftur. It is Skúli's work that Jón Árnason preserved in his collection, and it is indeed a majestic recreation of Loftur's story. Of Skúli's effort, Einar Ólafur Sveinsson says, "it is as if a folk-legend is on the way to becoming something more sophisticated; one might perhaps call it a myth." ${ }^{57}$ While Skúli gives the text its aesthetic appeal and complexity, the legends of Galdra-Loftur were among the most popular tales in Iceland even before Skúli's rewriting. Two other extant texts include stories of GaldraLoftur: Jón Espólín’s Árbækur (1821-1830) ${ }^{58}$ and Gísli Konráðsson’s Sögupættir, ${ }^{59}$ also from the early to mid-nineteenth century. Jón Espólín's account focuses on the corrupt nature of the boy Loftur, while Gísli and Skúli include many of the same anecdotes about his bad nature but focus primarily on Galdra-Loftur's attempt to acquire a magical book of great power. Jón Espólín's work, being the earliest, contributed evenly to the two later variants. Both Gísli and Skúli include the fundamental components of the Loftur legacy: (1) Loftur is a young magical prodigy, (2) he uses magic to cause trouble and play tricks on people, (3) he tries to gain more power by obtaining a magical book, and (4) he fails to do so and as a result loses his soul.

In terms of a folkloristic analysis, Skúli's work presents certain problems, most importantly because his version of the Loftur story offers a clear example of a learned nineteenth-century individual bringing his own aesthetic and literary intent to an otherwise orally transmitted narrative. An assessment of the cultural memory or of oral tradition based on Skúli's work must therefore proceed with caution. Despite these challenges, this examination will focus on Skúli's work for three reasons. First, as was remarked in the introduction to this book, regardless of whether the Loftur story is literary or a collected folktale, it is a wonderful story, certainly worthy of discussion. The popularity of the Loftur narrative both before and after Skúli's version should be enough to show that, even where Skúli might have deviated from oral tradition, the Loftur stories were not the singular invention of one individual but part of a broad body of storytelling about this figure. Second, Skúli's version fits seamlessly into the greater and older iterations of folk motifs associated with the Icelandic galdramenn, as we will discover in the next chapter. Third, Skúli's expansion of other accounts of Loftur does not reform but merely enhance what is present there. The two main innovations that Skúli

56 See below (120, note 11) for more on the Galdra-Loftur narratives. See also Hannes Porsteinsson, Galdra-Loftur: söguleg rannsókn (Reykjavík: Ísafoldarprentsmiðja, 1914), also printed in Ísafold 42 (January 1915): 2-4.

57 Einar Ólafur Sveinsson, Folk-Stories of Iceland, 212.

58 Jón Espólín, Íslands Árbækur í sögu-formi, vol. 9 (Copenhagen: Hið Islendska Bókmentafélag, 1830), 40-41.

59 Gísli Konráđsson, Sögubættir (Reykjavík: Einar Gunnarsson, 1915). 
brings to the narratives are an impressive aesthetic sensibility and the tragic depiction of Loftur's demise. The first takes away nothing from the cultural memory evident in the title, and the second, in those instances in which it seems to deviate from tradition, is easily compartmentalized. The story, in other words, contributes to an understanding of nineteenth-century Icelandic cultural memory, even if we acknowledge its literary rather than its oral quality. For these reasons, Skúli's version works well in a study of galdramaður tales, and in fact, we would be remiss to exclude it.

Like other Icelandic sorcerers, Galdra-Loftur has a mischievous streak, but from the very start his nature appears more corrupt and selfish than other galdramenn. At a young age Loftur takes to studying magic, conducting not just forbidden magic but malicious magical pranks on schoolmates, teachers, and friends, even to the point of killing a maidservant in his house after having got her pregnant. The tale states that Loftur, having learned everything there was to learn from the Gráskinna manual (which by that time had supposedly long been present at Hólar), ${ }^{60}$ he decides to summon from the grave the evil magician Bishop Gottskálk ${ }^{61}$ in order to take his magic book, Rauðskinna. Loftur employs a brave schoolmate to help him, but when he explains to the boy his reasons for wanting the book, he reveals an unexpected concern for the well-being of his soul. Skúli's version dramatizes this element of the story, having Loftur say:

peir sem eru búnir að læra galdur viðlíka og ég geta ekki haft hann nema til ills og verða peir allir að fyrirfarast hvenær sem peir deyja, en kunni maður nóg mikið pá hefur djöfullinn ekki lengur vald yfir manninum, heldur verður hann að pjóna honum án pess að fá nokkuð í staðinn eins og hann pjónaði Sæmundi fróða, og hver sem veit svo mikið er sjálfráður að bví að brúka kunnáttu sína svo vel sem hann vill. ${ }^{62}$

Those who are as learned in magic as I cannot use it except for ill, and they all become forfeit when they die, but if a man knows enough then the Devil no longer has power over him; rather the Devil must serve him without getting anything in return, just as he served Sæmundur the wise, and whoever knows that much is free and can use his skill in whatever way he wants.

Loftur further warns the boy to be diligent in his help because his temporal and eternal well-being ("stundleg og eilíf velferð”) depends upon their success. ${ }^{63}$ Without Rauðskinna, Loftur will never possess the ability to control the Devil and will thus be doomed to continue along his evil path and will be rewarded accordingly in the afterlife. Unlike the traditional Christian doctrine that the repentant soul must leave behind the sins and evils of their transgression, for Loftur (and other Icelandic magicians), it is the

60 Simpson notes that both Skálholt and Hólar were in possession of certain manuals of magic, both named Gráskinna (Legends of Icelandic Magicians, chap. 5, n. 1).

6I This is Gottskálk grimmi (the cruel) Nikulásson, bishop of Hólar from 1497 to 1520. See below, 139.

62 JÁ 1:573.

63 Other Icelandic magicians experience a similar dependence upon magic to save their soul, though Loftur fails to attain mastery. See 131-38 below for more on this point. 
forbidden knowledge and magical abilities that enables them to experience redemption. Raising the evil Bishop Gottskálk and going deeper into the forbidden knowledge promises - counter to Christian doctrine-to free him from eternal damnation. That he does not succeed makes Loftur's story a tragic tale rather than a redemptive one.

Skúli's version of the Galdra-Loftur tale also develops several important ideas concerning contests of spatial opposition. For instance, Loftur uses twisted rituals to profane sacred space for his own purposes. At the appropriate time, he and his helper go into the sanctuary, obviously itself a sacred space (in comparable stories, the conjuring might take place in a graveyard). As Loftur goes behind the pulpit and begins conjuring, he wilfully transforms this sacred space into a defiled one, not by the incidental shedding of blood or disregard for its sacrality, as was evident in earlier sources, but by an active and intentional abuse aided by sacred objects and rituals for the purpose of turning them to evil. Loftur populates the sanctuary with the raised corpses of bishops (except for those who were buried after a certain time, for it was later customary for bishops to be buried with a Bible on their chest, something that Loftur's conjurations could not overcome). Three of them wear crowns: doubtless one is Jón Ögmundsson (1106-1121), who plays a prominent role in the tales of Sæmundur fróði; another must be Guðmundr Arason (1161-1237), mentioned above; and a third is Jón Arason (1484-1550), the last Catholic Bishop in Iceland, who was brutally executed at the hands of Reformers. ${ }^{64}$ These crowned figures create a kind of arena in which the struggle between Loftur and Gottskálk will take place. The tale states, "stóðu pá prír hinir kórónuðu biskupar lengst frá með upplyftum höndum og snéru andlitum móti Lofti, en hinir horfðu undan og á pá" (the three crowned bishops stood farthest from Loftur with hands uplifted and they twisted their faces toward Loftur, but [the others] looked away from him and at the three bishops). ${ }^{65}$

Loftur defiles the sacred space by employing malefic, blasphemous magic, but it is a magic that draws its power from the sacredness of the Christian belief system. The tale says that during Loftur's struggled to raise Bishop Gottskálk, "snéri hann pá iðrunarsálmum Davíðs upp á djöfulinn og gjörði játningu fyrir allt sem hann hefði vel gjört" (he then twisted the penitential psalms of David up to the Devil and made confession for all the good that he had done). ${ }^{66}$ After Gottskálk taunts Loftur, he once more distorts Christian sacred prayers: "Snéri hann pá blessunarorðunum og faðirvori upp á djöfulinn" (He then twisted the benediction and Lord's Prayer to the Devil) ${ }^{67}$ This sort of malefic magic here denotes the direct distortion of a sacred object, prayer, or space for the express purpose of malevolence. A malefic magical act of this kind does

64 Simpson makes note of these figures in her translation of this tale (Legends of Icelandic Magicians, chap. 6, n. 2).

65 JÁ 1:573. After the duel Loftur states that the bishops would not have allowed Gottskálk to linger after the sunrise, indicating that they have some jurisdiction over the events of the duel.

66 JÁ 1:573.

67 JÁ 1:574. 
not, it must be understood, desacralize its subject; it rather draws its malevolent power from the inversion or distortion of the sacred subject. For instance, Loftur's recitation of the Lord's Prayer to the Devil achieves the desired effect because of the distortion, not in spite of it.

This sort of blasphemy is commonly involved in the raising or manipulation the dead, which allows some comparison with older traditions. While certainly present in medieval Norse mythology, necromancy begins to take on a remarkably different form than in post-medieval sources. The cult of Óðinn, most obviously, is often associated with necromancy, specifically for the sake of acquiring some arcane knowledge. After the Vanir kill and behead Mímir, Óðinn enchants Mímir's head so that it can still impart wisdom to the Æsir. ${ }^{68}$ This motif is used in similar fashion in a later folktale about a certain Porleifur who takes the head of a recently drowned man (some say it is the head of a child), feeding it bread and wine and keeping it in a chest or crag, all for the purpose of acquiring knowledge from it. ${ }^{69}$ Another tale tells of a magician who uses the dead to acquire knowledge: "Útisetur á Krossgötum" (Sitting Out at the Crossroads), in which the magician must lie down at a crossroads and cover himself completely with an animal hide so that nothing of himself is showing. ${ }^{70}$ Then he must stare at the edge of an axe and conjure the dead from the four churchyards, and if he has any relations in the graveyards, they will come to him and tell him whatever he wishes to know. ${ }^{71}$ The act evokes images of the conversion to Christianity in 999/1000, when law speaker Porgeirr Porkelsson retired under his cloak for an entire day in order to seek guidance on whether the country ought to accept Christianity, and indeed Jón Hnefill Aðalsteinsson has linked Porgeirr's actions on that day to similar kinds of sorcery elsewhere in the Norse belief system. ${ }^{72}$

Tales like "Galdra-Loftur," which involve necromancy and other manipulation of the dead, often incorporate malefic incantations. "Skollabrækur" (The Devil's Underpants) ${ }^{73}$ gives careful instructions for how to make a pair of breeches whose pockets never lack a coin, no matter how often you reach for one. In order for them to work, however, the

68 See Snorri Sturluson, Ynglinga saga, ed. Bjarni Aálbjarnarson, Íslensk Fornrit 26 (Reykjavík: Hið íslenzka fornritfélag, 1941), chaps. 4 and 7.

69 JÁ 1:507-8. Jacqueline Simpson makes passing reference to this in Icelandic Folk Tales \& Legends.

70 JÁ 1:422-24. As Jacqueline Simpson notes, the motifs in this tale bear a strong resemblance to those in the tale "Krossgötur" ("Crossroads"; JÁ 1:118), in which an individual can sit out at a crossroads in order to procure treasures from the elves (Icelandic Folk Tales \& Legends, 72 and 190). That the motif transcends the mythic structure to signify both elves and deceased family members as knowledge keepers indicates the importance of the motif in the later belief system.

7I Simpson notes that this sort of necromancy was common in Iceland and Norway since medieval times and that Christian law forbade a man from engaging in such acts (see Icelandic Folk Tales \& Legends, 192).

72 Jón Hnefill Aðalsteinsson, Under the Cloak, 103-23.

73 JÁ 1:415. 
wearer must first steal a coin from an extremely poor woman during a church service, sometime between the reading of the Epistles and the reading of the Gospel. ${ }^{74}$ Likewise, Jón Árnason points to other examples of malefic magic in his explanation of methods for raising the dead. The sorcerer, he explains, must enact the ritual at midnight on a prescribed night — some think a night between Friday and Sunday, others say between the 18th and 19th or the 28th and 29th of the month-and he must write the Our Father backwards on a piece of parchment in his own blood, then, selecting the grave, he must chant the reversed Our Father along with other secret sayings. ${ }^{75}$ Necromancy for the sake of acquiring knowledge also plays a role in stories about magicians who raise the dead to attain a magic book. Both Eiríkur of Vogsós ${ }^{76}$ and Galdra-Loftur raise long-dead magicians in order to steal their magic books. In both tales the motif of raising the dead functions as a guide for those who seek to understand how, in the (Icelandic) Christian world, the magicians must approach power, good and evil, and the prospect of death. The motif likewise illuminates the consequences of both righteousness and unrighteousness in a Christian sense. The distinctions between good and evil, righteousness and unrighteousness, prove to be more complicated than one might originally suspect, and understanding that complexity brings us closer to understanding the mythic structure ingrained in the later folktales.

The Loftur story merges these notions of blasphemy and necromancy with the defilement of sacred space. We can no longer call this space "sacred" after the blasphemy and necromancy enacted upon it by Loftur, yet neither is it merely "profane" in the sense of being outside the Church or even outside Christendom; it is rather "profaned space," which has become so by a maleficent ritual meant to distort the sacredness of an otherwise christened, holy place. In the Loftur stories, Loftur clearly draws his power from both the sacredness of the space itself and the maleficent ritual acts of profanation he acts upon the space. Much more than simply having lost its sacred element (as was the case with tainted space in Old Norse depictions of pre-Christian Iceland), profaned space must be defined as a space that was once sacred but has been made evil by some act of profanation, often twisted by blasphemous or sacrilegious ritual. In this sense, profaned space is only possible in a cultural memory that acknowledges the stark polarity between good and evil, such as is found in what may be called the Christian, and especially in Lutheran, "cosmic war," in which forces of good and evil vie against one another. It is also a phenomenon that occurs within a single religion, rather than between two separate religions, as was the case in contests between pagan and Christian spaces.

\section{The Cosmic War and the End of Loftur Porsteinsson}

The fact that Loftur is seeking a kind of redemption, though he fails, affords considerable context to the means by which he struggles to that end: Loftur's malefic conjurations

74 JÁ 1:415.

75 JÁ 1:304-5.

76 Numerous stories circulated about Eiríkur of Vogsós. Many are collected in JÁ 1:543-65. 
serve to create not merely an ambiguated space but rather one that has been profaned, into which he enters for the purpose of raising the dead. The arena is thus set for his redemption, and the three crowned figures serve as his guardians, ready to instruct him on the return (Bishop Jón has already given him a warning, in fact).$^{77}$ Loftur might have succeeded, too, but for his pride. He goes into such a frenzy of conjurations that the schoolboy, who has been charged with ringing the church bell at the appropriate time, misinterprets Loftur's reaching for Rauðskinna as the signal and rings the bell, sending all the bishops back into their graves. After the fact, Loftur tells his schoolmate that he became so obsessed with the prospect of taking the book by conjuration that he forgot all else. Had he chanted any more verses, he would have sunk the cathedral into the ground. He stumbled, says Loftur, because he saw the faces of the bishops, who seem to serve as officiators over the duel between Loftur and Gottskálk. Had the bishops not caused Loftur to stumble at the last moment, the price for his total failure would have been the destruction of the church in which the duel took place. As it stands, the bishops prevent such a calamity, and it is only Loftur who must sink tragically to his own demise. ${ }^{78}$

It must be remembered that the body of Christ and Heaven represent only one side of the Christian worldview. The Devil and Hell complete the landscape. From the Christian-especially from the Lutheran-perspective, the world is the site of an epic battle, one in which the Good triumphs but that nevertheless is played out in the human arena, where casualties are counted in the currency of human souls. A similar contest was evident in medieval Iceland, though it was not a war between Heaven and Hell but between Christian and pagan. Sîn Grønlie notes that such contests point to an Augustinian view of conversion. ${ }^{79}$ Sverrir Jakobsson points out that this contest between Christian and pagan forces is nowhere better on display than in the well-known episode from Piðranda páttr, where piðrandi, "a well-behaved and noble youth," ${ }^{80}$ is killed by nine pagan fylgjur. Sverrir thus points out that "At the center of this struggle [between Christianity and paganism] is an unfortunate youth, an unwilling observer of this cosmic struggle." ${ }^{11}$ In the post-Reformation variation on this contest, Christianity battles not against paganism but against the Devil himself, and the "youth" at the centre

77 If we recall that Loftur has already once referenced Sæmundur fróði and the Black School, then we can conclude that, in terms of the narrative at least, both the storyteller and the characters in the tale understand that Jón Ögmundsson has served this function once before for Sæmundur froð $i$.

78 The difference between Sveinn in "Tungustapi," and Loftur may not be immediately apparent. In the case of "Tungustapi," the hero of the tale actually completes the rite of redemption (recall that his love for his family facilitates the redemption stage for him), and only at the reckoning stage is he held accountable for his actions. Loftur fails to complete the rite and thereby suffers a different fate from that of Sveinn.

79 Sîan Grønlie, "Reading and Understanding': The Miracles in Porvalds páttr ens víðforla," The Journal of English and Germanic Philology 112 (2013): 475-94 at 482.

80 Sverrir Jakobsson, "Conversion and Cultural Memory," 23.

8I Sverrir Jakobsson, "Conversion and Cultural Memory," 23. 
of this struggle, as represented in post-Reformation tale "Galdra-Loftur" is neither "well-behaved" nor "noble." Instead, the well-behaved and noble youth of the Christianpagan struggle in Piðranda páttr has been transformed into the complicit, ignoble, and sinister youth of the "Galdra-Loftur" tale, but the (eternal) well-being of the youth at the centre of the struggle remains the casualty of the battle.

It seems, then, that even more so than its Catholic predecessor in the country, the post-Reformation Icelandic cultural memory was keenly aware of this epic struggle against evil. Martin Luther would have whole-heartedly affirmed the recognition of this epic battle. For Luther, the Devil was an ever-present enemy. Heiko A. Oberman, biographer of Luther has said,

Luther's world of thought is wholly distorted and apologetically misconstrued if his conception of the Devil is dismissed as a medieval phenomenon and only his faith in Christ retained as relevant or as the only decisive factor. Christ and the Devil were equally real to him: one was the perpetual intercessor for Christianity, the other a menace to mankind till the end ... Christ and Satan wage a cosmic war for mastery over church and world. ${ }^{82}$

The writings of Bishop Jón Vídalín (1666-1720), which were so important to postReformation thought, will attest that Icelandic Lutheranism took this cosmic war quite seriously. ${ }^{83}$ Sigurdur Arni Thordarson argues that Vídalín depicts the Fall of humankind in spatial terms: "As a created being the human is placed within a circle that may not be broken. Attempts to transcend the limits will result in a fall. This fall is interpreted spatially. The sin consists in trying to place oneself higher in the hierarchy of values, than one is allowed." ${ }^{84}$ Icelandic folklore seems to have taken the spatial nature of the Fall equally seriously, though not in ways that might be expected.

After Loftur's failure to secure the magic book, the concepts of transcending and transforming spaces remains crucial. Loftur falls into a deep depression, unable to bear darkness or to be alone for very long. He seeks the help of an elderly cleric, who pities Loftur and tries to save him from his fate by allowing him to participate in his vocational care of others. Loftur finally grows so weak that he cannot accompany the cleric, and, once, thinking Loftur will be safe enough if he remains inside, the cleric leaves him alone. Before he leaves, however, the cleric fortifies the threshold of the house: "fyrir bæjardyrum féll hann á kné og baðst fyrir og gjörði krossmark fyrir peim" (he dropped to his knees before the door of the house, prayed before it, and made the sign of the cross on it). ${ }^{85}$ Here, truly sinister evil is signalled by a spatial and ritual response to the threat. The prayers and blessings of the cleric represent an attempt to establish a protective barrier around Loftur, but the efforts cannot save the young man. After the

82 Heiko Augustinus Oberman, Luther: A Man between God and the Devil, trans. Eileen WalliserSchwarzbart (New Haven: Yale University Press, 1989), 104.

83 See Thordarson, Limits and Life, 87-95, for more on the Icelandic view of this war.

84 Thordarson, Limitation, 153-54; see also Limits and Life, 97.

85 JÁ 1:575. 
cleric leaves, Loftur mysteriously recovers from his illness and elects to leave the safety of his protective space. He is never seen alive again. ${ }^{86}$

\section{“Galdra-Loftur," “Tungustapi," and the Inward Turn}

Sveinn's struggles and suffering in the tale "Tungustapi” somehow mirror the struggles and suffering of Galdra-Loftur. Both desire a secret, forbidden knowledge or initiation; both try, and fail, to attain it; both withdraw from the world, ultimately into the care of members of the Christian church; both die as a result of their trials; and both tales also have a strong dependence, though not in the same way, upon the notion of contested sacred spaces. The manner in which they articulate that dependence illuminates a final step in the development of cultural memories of space in Iceland.

The transition from Catholicism to Lutheranism in Iceland provoked a dramatic shift in the locus of sacred space. Sigurdur Arni Thordarson points out that in postReformation Iceland, "homes rather than the churches became the loci of religious formation," particularly in the sense of the daily education of Icelandic families: ${ }^{87}$ It was common for pastors in post-Reformation Iceland to attend to the needs of specific households as caregivers, educators, and even as defenders and arbitrators of the way of life at the farmsteads under their care ${ }^{88}$ This localizing ${ }^{89}$ of sacred space to the home or farmstead accompanied an increasing internalization of the sacred that took place after the Reformation. Whereas Catholicism endorsed (or at least tolerated, in the less traditional cases) a variety of physical locales to which constituents might go to enter sacred space, the teaching of the post-Reformation church continued the trend of localization, going from church to farmstead or home and then turned inward to the body, heart, and soul of the believer. It was inside the individual heart that the temple of God resided.

86 The Jón Árnason version of the tale states that he went out in a boat with a local fisherman, and a large grey hand dragged down both boat and men. Ólafur Davíðsson's version suggests suicide as the cause of death (Ólafur Davíðsson, Pjóðsögur, 2:129-32). Simpson suggests that the latter is more reasonable (Legends of Icelandic Magicians, chap. 6, n. 2).

87 Thordarson, Limits and Life, 52.

88 The church edifice also offered a form of protection against the dangers of the land (Thordarson, Limits and Life, 54). See also William H. Swatos, jr., "The Relevance of Religion: Iceland and Secularization Theory," Journal for the Scientific Study of Religion 23 (1984): 34, as cited in Thordarson, Limits and Life, 53. Further evidence of this phenomenon can be found in Diplomatarium Islandicum, 16 vols. (Reykjavík: Hið Íslenzka bókmentafélag, 1857), 1:291; and Grágás: Lagasafn Íslenska bjóðveldisins, ed. Gunnar Karlsson, Kristján Sveinsson, and Mörður Árnason (Reykjavík: Mál og Menning, 1992), 43. Sverrir Jakobsson discusses these examples of church sanctuary and instances in Icelandic literature when it was challenged. See Sverrir Jakobsson, "Heaven Is a Place on Earth," Scandinavian Studies 82 (2010): 15-16.

89 Despite the pastors' increased presence within homes, it would be wrong to assume that the edifice of the local church was of no consequence. Pastors conducted the major rites in the church, like baptisms and marriages, and the church became an important place for social interaction as well as the first stop before leaving on a long voyage. See Thordarson, Limits and Life, 53. 
This movement, sometimes called the "indwelling of God," became of special important to Reformation doctrine in Iceland. Bishop Jón Vídalín offers a good example of the subject in his hvítasunnuhátíð (Pentecost) sermon. ${ }^{90}$ He begins by making use of Zechariah 6:12, which presents the image of two worlds: one is the visible world, which we see with physical eyes and in which we live, and the other is the world above, in Heaven, from which Christ will come at the end times. In Porlákur Skúlason's (bishop of Hólar from 1628-1656) version of the Icelandic Bible, which Jón Vídalín would have read, the passage reads, "Siaðu, par er eirn mann sem heiter Zemah, pvi under hønum skal pat vaxa og hann skall byggia mustere Drottins" (Behold there is a Man whose name is the Zemah [the Branch]; he shall grow out from where he is, and he shall build a temple to the Lord). ${ }^{91}$ On this passage, Jón Vídalín elaborates in a sermon for Pentecost, 1718-1720: "Раð er Guðs kirkja í mannanna hjörtum, í hverjum Kristur býr fyrir trúna, og hann er par sjálfur kennimaður í sínu hásæti, og ráð friðarins á milli beggja” (This [temple] is God's Church in the hearts of men, in which Christ dwells through faith; for He is Himself the Priest there on his throne, and the Counsel of peace between them both)..$^{92}$

The opposition of the two worlds would appear to fall in line with the typical duality of physical and spiritual existence, and indeed Jón proceeds along these lines throughout his sermon. He concludes, however, by explaining that the duality will not hold. Of the earthly world, he says, "Pessi er sú önnur veröld er eg í upphafi talaði um, hver eð uppbyrjast hér í náðinni en fullkomnast síðar í dýrðinni pá Guð verður allt í öllu ..." (This is the other world of which I spoke at the start, begun here by grace and which will be perfected in glory when God becomes all in all ...).$^{93}$ In other words, the world in which we live and which we see with our physical eyes is in process. We do not transcend from the physical to the spiritual world as a Neo-Platonist might, sloughing off our regrettably physical condition to attain a higher, spiritual one; we rather observe and participate in the transformation of the world around us as it becomes the promised New Heaven and New Earth (Rev. 21:1). The root of this transformation, and our participation in it, comes from the indwelling of God. Says Jón Vídalín: "hann sem býr í himninum, hverjum að pjóna púsund og tíusinnum hundrað púsund heilagra engla, hann hefur búið sér vist í peirra hjarta hér á jörðunni sem hann elska og hans orð varðveita" (he who lives in Heaven, upon whom wait a thousand and ten times a hundred thousand holy angels, has made a place in the hearts of those here on earth who

90 Jón Porkelsson Vídalín, Vídalínspostilla: Hússpostilla eður Einfaldar predikanir yfir öll Hátíða og Sunnudagaguðspjöll árið um Kring, ed. Gunnar Kristjánsson and Mörður Árnason (Reykjavík: Mál og Menning, 1995), 485-94.

9I Biblía pað er öll heilög ritning (Spámannabækurnar) (Hólar: n.p., 1644), 240, http://baekur. is/bok/000036976/2/240/Biblia_thad_er_oll_heilog/?iabr=on\#page/Blaðs\%C3\%ADða+\%5B240 $\% 5 \mathrm{D}++(240+/+388) /$ mode/2up.

92 Jón Porkelsson Vídalín, Vídalínspostilla, 486; my italics.

93 Jón Porkelsson Vídalín, Vídalínspostilla, 494. 
love him and keep his word). ${ }^{94}$ The focus of sacredness is, at least theologically, turned away from external, localized spaces such as churches, blessed springs, and pilgrimage sites, and toward the internal heart in which Christ dwells. In a certain way, the change diversifies the sacred landscape to include every individual constituent of a church community.

Both "Tungustapi" and "Galdra-Loftur" embody this internalization by the manner in which they approach their deaths. ${ }^{95}$ They turn inward, abandoning the outward world and reflecting upon the conditions of their own souls, rather than outward. I have argued elsewhere that this internalization is due to a fundamentally Christian type of cultural memory called "cognitive prospective memory," in which the approach to death is marked by a strong internal sense of culpability and concern for one's prospects for eternal life. Cognitive prospective memory must, I argue, be set in contrast with "heritable prospective memory," which is a type of cultural memory inherent in pagan belief systems. Thus, whatever heterodoxy may be present in these tales about Loftur and Sveinn, they are fundamentally Christian in their approach to death. By contrast, piðranda páttr stands as a transitional narrative between these two prospective memories of death. While piðrandi tragically loses his life during the global struggle between Christianity and paganism, Galdra-Loftur loses his soul (but not yet his life) in the personal struggle between orthodoxy and heterodoxy. The audience must watch him slowly wither away into his damnation until he is taken by the Devil himself. The important contribution that these stories make to a discussion of prospective cultural memories is that their internalization takes on a deeply post-Reformation identity: their internalized view of death and the afterlife is echoed by an externally manifested contest of spaces.

\section{Final Thoughts: Church Moving and the Elf Church at Tungustapi}

The contest of sacred spaces in the folktale "Tungustapi" must be understood within a larger context of cultural memory that reaches back to the beginnings of Iceland. Even in the earliest written sources in Iceland, and perhaps even earlier in oral traditions, Christian sacred space competed with pagan sacred spaces. Whatever the actual history might have been, it is clear that the cultural memory hidden within those early written sources perceived pagan sacred spaces through a Christian lens (as is evident in our discussion of Eyrbyggja saga), which was in turn buttressed by the profound importance of sacred spaces evident in Judeo-Christianity. As is evident in thirteenth-century legal texts, a different type of space develops in the course of the medieval period: a sacred space that is Christian but has been tainted or defiled. This is a space that begins as sacred space, such as a church, and is stained in some way by an evil act, though an evil act not directed at or intended to alter sacred space. The defilement of sacred space here is but a consequence and can be restored through proper ritual.

94 Jón Porkelsson Vídalín, Vídalínspostilla, 494; my italics.

95 See Bryan, "Prospective Memory of Death and the Afterlife." 
The moving story of "Galdra-Loftur" affords us another type of contested space, which must be added to the three already mentioned. Even though this fourth space is witness to a contest between good and evil, it remains within the purview of Christianity because this contest participates in the cosmic war as articulated by Christian doctrine. In other words, it is a cultural memory of sacred spaces defined by Christian ideas and therefore must be considered to have a Christian identity. The four types of contested space that have developed throughout the religious history of Iceland are, then, as follows:

1. Contests between Christian and pagan spaces;

2. contests within (Christian) accounts of pagan spaces that have been defiled and from which sacredness has been lost;

3. contests between Christian sacred spaces and defiled sacred spaces that must be cleansed;

4. contests between orthodox and heterodox Christian spaces, in which Christian sacredness is turned in upon itself to create a profaned space.

The contest of sacred spaces in "Tungustapi" confounds this typology because it sits squarely in the gaps between these four types. Like the pagan temple described in Eyrbyggja saga, the elf church is understood through a Christian lens. It is familiara mirror image of the Christian church, a mythical inversion of the Christian church opposite it. The elf church sits inside the hill in the west and its doors face east, whereas the Christian church stands in the east and faces west. When the elves choose to keep them closed, the doors ("kirkjudyr," church doors, in the text) of the elf church appear as a part of nature, a solid rock barrier; but at certain times, such as the turn of the New Year, they serve rather as a threshold between the ordinary world and the elfish sacred space within. In contrast, the Christian church's doors, which ought to serve as a threshold between the ordinary space outside and the sacred Christian space within, become a barrier when Sveinn requires them to be bound shut on the Easter that he is to perform mass. Likewise, the elf priest is sometimes referred to as "álfabiskupinn" (the elf bishop) in the tale, marking him as an elfish antithesis to the Christian bishop. But there is something less wholesome about the elf church. It cannot wholly escape that new type of defiled Christian space, which is tainted or profaned.

The elf church holds a mystical power that cannot be attained in the present world, yet anyone who seeks initiation into the elfish priesthood must pay a high price. Had Sveinn completed his initiation, he would have been required to sacrifice his love and benevolence for his family. For Icelanders, who are so very family conscious, this would have been a horrible price to pay. When Arnór shouts at Sveinn during the initiation ceremony, the story says, "Hrekkur Sveinn pá við, stendur upp og lítur utar eftir; vill hann pá hlaupa móti bróður sínum” (Sveinn then started up, and looked out; he wished to run toward his brother).${ }^{96}$ As a result he is cursed. Specifically, says the

96 JÁ 1:33. 
elf priest, “En fyrir pað að pú stóðst upp í pví skyni að ganga til bróður píns ...” (But therefore [you will be cursed because] you stood up for the purpose of going to your brother). ${ }^{97}$

All of these details enable "Tungustapi" to evade any classification of contested sacred spaces. The contest between the two spaces may be (1) a contest between Christian church and a space indwelled by "pagan" supernatural creatures or (2) a mythical space defiled by an irreverent guest (Sveinn's brother, Arnór), as in Eyrbyggja saga, but these designations do not explain why the elf church looks like a Christian church and the elf bishop look like a Christian bishop. The Christian church in contest with the elf church might also be called (3) a Christian space that has been inadvertently defiled by some act of violence (the deaths of Arnór and Sveinn), which might explain why it must be moved, but it does not explain what the elf church is or why it has won the contest. Finally, the twisted versions of Christian ritual, blasphemous elf bishops, and a mockery of a Christian church all look, perhaps, most like the profaned space that we find in "Galdra-Loftur," yet there is no evidence of any act of profanation such as Galdra-Loftur's recital of the Lord's Prayer to the Devil or repenting of all the good he has ever done. The contest of sacred space in "Tungustapi" thus does not conform to any of these four categories, yet so much may be the very function and purpose of the story within the cultural memory of sacred space in Iceland. The contest between the elf church and the Christian church was never meant to produce a "winner" and a "loser" as was posited earlier in this chapter. Instead, it was meant to demonstrate the costs and rewards of mediating between the two competing spaces.

Only Sveinn has the ability to mediate between the two spaces, and he does so for a long time before his brother dies. Even prior to the fateful New Year's Eve, Sveinn was known to walk alone not only around the elf church at Tungustapi but also around the Christian church, ${ }^{98}$ while afterwards he retains the beauty and mystery of the elfish world and turns it to the benefit of the Christian world. There is nothing twisted or profaned (as in "Galdra-Loftur") about the Christian mass he sings or the Christian wisdom for which Sveinn is known, but his ability to mediate between the two spaces comes at an even greater cost than he would have paid had he been initiated into the elf priesthood. It would be easy-and perhaps true enough - to say that this mediation is between heterodox belief in supernatural creatures and orthodox belief of the Church, but some deeper, more fundamental truth may also be at play in the story of "Tungustapi": beauty and wisdom - the deep sort of beauty and wisdom for which Sveinn was especially known-require some kind of transgression, a passage into a forbidden space which must needs be condemned by the world above, yet more so, that kind of beauty and wisdom comes not from merely transgressing the barrier between Christendom and the forbidden realm of the elves, but rather from going into the forbidden world ... and returning home.

97 JÁ 1:33; my italics.

98 JÁ 1:32. 
In the next chapter, we will discover that these types of costly and beautiful transgressions into an otherworld, and their subsequent boons of wisdom, beauty, and-in the case of the Icelandic galdramenn-magical prowess, have deep roots in the cultural memory of religious beliefs in Iceland and beyond. 


\section{Chapter 5}

\section{THE STUPID BOY AND THE DEVIL: S/EMUNDUR FRÓĐI SIGFÚSSON, MAGIC,AND REDEMPTION}

\section{“Tornæmi Drengurinn og Kölski”" (The Stupid Boy and the Devil)}

Sæmundur fróði once had a young boy working for him who was so stupid he could not learn anything at all, not even the basics of Christian doctrine. The boy was very bothered by this and often said he would rather like to be clever. One night a man came to him in a dream and offered him the chance to be very clever indeed if the boy would only promise to come and serve the man's household on Holy Cross Day the following spring. The boy gladly agreed and when he awoke, he felt himself to be as clever as any boy in Iceland. He impressed many with his abilities, even Sæmundur the priest, who knew a thing or two about being clever. As time passed, the boy became sullen and frightened. Finally, he confessed the whole story to Sæmundur. The priest told the boy he had surely been visited by the Devil himself, but not to worry ... Sæmundur would help him out of his troubles.

On the eve of Holy Cross day, Sæmundur told the boy to come with him to the church, where he put vestments on the boy, gave him the bread and wine of Holy Communion, and told him exactly what he must do. The boy, said Sæmundur, must face the nave and offer the Communion bread and wine to whoever should enter the church, and if they refused to partake of the bread and wine of Communion, then the boy must under no circumstances go with them. With that, Sæmundur left the church.

Not long after, the man from the boy's dream entered the church and said that it was time he came into his service. The boy said nothing, only offered the bread and wine of Communion. The man said he was not interested in what the boy was holding and demanded that he come as he had promised. The boy did not move, and eventually the man left angrily. After that, many of the boy's friends came one by one and tempted him to leave his spot. Some grew angry. Finally, Sæmundur himself entered the church and told him that he must come with him, but the boy did not move and only offered the bread and wine. Sæmundur grew angry and told him he had not come for Communion and that the boy was to come with him immediately. When the boy would not, Sæmundur turned and stormed out of the church. After that, all manner of devils and evil spirits seemed to storm the church and flew about making all sorts of awful disturbances until the boy thought the church itself would crumble to the ground. At last, the boy heard church bells ringing and all the visions ceased at once. At last, the real Sæmundur entered and said not a word, only

I JÁ 1:483-84. This story was collected from Markús Gíslason (1837-1890). Another version was recorded in Ólafur Davíðsson, Íslenzkar bjóðsögur, 4 vols. (Reykjavík: Bókaútgáfan Pjóðsaga, 1978-80), 2:303-5. 
took Holy Communion from the boy, and told him there was nothing more to fear. The Devil would not trouble him anymore.

The boy thanked Sæmundur for his help and was devoted to him for the rest of his life. The boy, it is said, was able to keep his cleverness and became a famous man in Iceland.

This little story has a great deal to offer a discussion of Icelandic folk traditions and cultural memory. ${ }^{2}$ Morphologically, it is related to a Finnish tale (E551) in which a woman inadvertently promises her unborn son to the Devil on his fifteenth birthday, but when the Devil comes to collect, the boy appeals to a priest for help. The story also has affinities with several important Indo-European tale types-The Priest and the Devil (ATU 810A*), The Man Promised to the Devil Becomes a Clergyman (ATU 811), The Sorcerer's Apprentice (ATU 325), The Youth Who Wanted to Learn What Fear Is (ATU 326), and especially The Smith and the Devil (ATU 330) - as well as motifs involving deals with the Devil-M211 and especially M216.1 (the Devil helping a man study for the priesthood in exchange for his soul). But there is also something deeply, uniquely Icelandic about the story: it features Sæmundur fróði Sigfússon, one of the most prominent Icelanders of both history and legend; and Holy Cross Day, the prescribed day the boy must go with the Devil, is a reference to May 3, the Icelandic Moving Day, when hired labourers could move from the service of one farm to another. Thus, it is significant that the boy, who is initially in Sæmundur's service will go into the service of the Devil on May $3 .^{3}$

In addition to these points, the careful reader may be compelled to acknowledge certain curiosities about the story: First, as we shall see from the morphological analysis below, the presence of Sæmundur fróði seems to be rather superfluous. He plays a significant role in the long-developing figure of the Icelandic galdramaður, sorcerer, but this story is about cleverness and the Devil, not magic, and while it is true that Sæmundur fróði is said to know how to deal with the Devil, he does not deal with the Devil himself; he merely tells the boy what he must do. What, exactly, is Sæmundur's function in this story? Second, sacred space and ritual play prominent roles in the defeat of the Devil in this story. The boy must stand just so in the church, wear the vestments of a priest, and offer the sacrament of Holy Communion to anyone who enters. In most stories about defeating the Devil (in the above motifs and tale types), it is not ritual and space but clever (often petty) tricks that bewilder an overmatched devil figure. This devil is quite the contrary-not a fool, easily gulled, but quite a sinister figure who looks as if he really could steal the boy's soul (even though he fails in the end). Why is this story different? Third, and perhaps most importantly, this story seems to take special care to say that the boy keeps his cleverness and goes on to be a prominent figure in Iceland. While it is not uncommon in folk narratives in the tradition of The Smith and the Devil (ATU

2 According to Jón Árnason's notes, the source for this story was Markús Gíslason of Mýrasýsla (1837-1890), who was a schoolboy at the time and went on to become a priest.

3 Simpson, Legends of Icelandic Magicians, chap. 5, n. 15. See also Árni Björnsson, Saga daganna (Reykjavík: Mál og menning, 1994). 
330) for characters to retain whatever it is the Devil has given them, there is something quite unsettling about this instance from a theological perspective. It is not obvious that anyone should keep what the Devil has given them, cleverness least of all, which can be either a good or bad quality depending upon how it is used. We need only look at the most fundamental of Christian narratives-the story of Adam and Eve in the Garden of Eden-to see how receiving cleverness from the Devil might become a serious problem. Why is the Devil's cleverness a good thing here?

We will take these questions in reverse order.

On the one hand, the fact that the boy is able to keep his cleverness may be nicely accounted for by recognizing the story's possible connection to international tale types and motifs. The Indo-European folklore landscape is peppered with examples of clever persons receiving something from the Devil in exchange for their souls and then outwitting him when the time comes. Connecting this story with the tale type The Smith and the Devil (ATU 330) is especially interesting because it associates this Icelandic story with possibly the oldest known tale type in the Indo-European world. Recent work done by Sara Garça da Silva and Jamshid J. Tehrani have applied a comparative phylogenetic analysis to explore the origins of several Indo-European folktales, ${ }^{4}$ and they have identified the origins of ATU 330 as plausibly going back 5,000-6,000 years to the Bronze Age. ${ }^{5}$ However, religious developments at various times in the various regions in which the basic story might be found will have influenced the story according to the beliefs and cultural pressures at play. Whatever this tale type may have been before the introduction of Christianity, it must have developed to accommodate the new religion, including its conception of good and evil.

From here we may turn to the Stith Thompson folk motif M216.1, in which we see evidence of those religious influences. This motif describes a story in which a man becomes a priest with the aid of the Devil, but during his studies discovers a way to save himself from the Devil. This would seem to fit nicely with the Icelandic story of the stupid boy and the Devil. Even though the story does not mention the boy becoming a priest, the tale specifically mentions his desire to learn Christian doctrine, and it is a ritual normally conducted by a priest, Holy Communion, that he enacts while dressed in a priest's vestments. There is considerable value to this connection, but this interpretation only goes so far. The principal difficulty is that the picture of evil in "The Stupid Boy and the Devil" seems rather different from those farcical, ineffectual devils-such as the vanapagan (Old Boy or Stupid Devil) discussed by Ülo Valk and others-that tend to occur in similar international tales associated with ATU 330 and M216.1. ${ }^{6}$ The Devil

4 Sara Garça da Silva and Jamshid J. Tehrani, “Comparative Phylogenetic Analyses Uncover the Ancient Roots of Indo-European Folktales," Royal Society Open Science 3 (2016): 1-11.

5 Da Silva and Tehrani, "Comparative Phylogenetic Analyses," 9.

6 See Ülo Valk, The Black Gentleman: Manifestations of the Devil in Estonian Folk Religion (Helsinki: Suomalainen Tiedeakatemia, 2001), 12-13. Valk notes that the word vanapagan literally means "old heathen," but that in Estonian folklore the word has come to refer either to the stupid devil or the primeval giants who have left marks of their existence upon the landscape in the form of boulders and hills (Valk, Black Gentleman, 12n2). 
in "The Stupid Boy" is sinister, capable of elaborate deceptions and disguises, and the commander of a host of monsters and demons that come to terrorize the boy and almost destroy the church. We get the sense that in this case, the Devil really could take the boy's soul, even though he is ultimately thwarted. "The Stupid Boy and the Devil" comes closer to the great cosmic war between God and the Devil discussed in the previous chapter, which, as Heiko A. Oberman suggests, had such an impact on the Lutheran mentality. ${ }^{8}$ In the great cosmic war, the prize is authority over the Kingdom of God and the casualties are the souls that might be stolen by the Devil and lost to eternal damnation. Reading this tale as a skirmish in the great cosmic war sheds light on the second of the intriguing peculiarities of "The Stupid Boy and the Devil": the importance of space and ritual.

Sæmundur instructs the boy to do exactly as he says: he must be standing in front of the altar, facing the nave, wearing the vestments, and holding the Sacraments; he must offer the Sacraments to anyone who enters and must not take even one step toward anyone-even Sæmundur himself-if they will not first accept the bread and wine of Communion. His success depends entirely upon both maintaining an appropriate relationship to the sacred space and adhering to the ritual of Holy Communion. These two elements, space and ritual, seem to indicate something about the severity of the threat the boy faces. Much like the uses of space and ritual discussed in the previous chapter, here we see the two working together to combat evil: it is through space and ritual that the boy will save his soul, or lose it. The consequences of losing this battle also involve the sacred space of the church. While the boy is resisting the visions of monsters and demons, it seems to him that "kirkjan hristast og skjálfa og hélt að hún mundi pá og pegar sökkva eða fara um koll" (the church began to shake and shiver, and he thought it would sink into the ground or come crashing down right then and there). ${ }^{9}$ That the church might sink into the ground is another motif common in both local Icelandic and international narratives. Internationally, the story draws from the Stith-Thompson motif F941.2 (Church sinks underground). ${ }^{10}$ In Iceland, F941.2 features in other narratives as well, most notably in a story discussed in the previous chapter, about Loftur Porsteinsson, Galdra-Loftur (the most sinister and tragic of all Icelandic galdramenn $)^{11}$. According to the narrative about him, Loftur

\section{108-11.}

8 Oberman, Luther, 104.

9 JÁ 1:484.

10 For a recent discussion of this motif, see Sandis Laime, "The Place Valence Approach in Folk Narrative Research: The 'Church Sinks Underground' Motif in Latvian Folklore," in Storied and Supernatural Places: Studies in Spatial and Social Dimensions of Folklore and Sagas, ed. Ülo Valk and Daniel Sävborg, Studia Fennica Folkloristica 23 (Helsinki: The Finnish Literature Society, 2018), 80-92.

II Historical sources indicate that Loftur Porsteinsson was born in the early 1700 s and that he went on to become a student at the Hólar Cathedral School (Einar Ólafur Sveinsson, Folk-Stories of Iceland, 207). Hannes Porsteinsson has done the most thorough examination of the legacy of Galdra-Loftur stories in his discussion of the 1915 play by Jóhann Sigurjónsson in the January 9 
tries to raise from the dead the evil bishop-magician, Gottskálk grimmi (the cruel) Nikulásson, ${ }^{12}$ for the purpose of stealing his magical book. Like the eponymous stupid boy, Loftur relies upon rituals - the Lord's Prayer, the singing of Hymns, and the act of confession-to achieve his purpose, although this time he reverses the rituals to pray to the Devil, glorify evil, and confess all the good he has done in his life. These parodies of Christian ritual are common to the international motifs G243 (Witch's Sabbath) and 243.2 (Parody of Church Ceremony at Witch's Sabbath).$^{13}$ In the Loftur story, these motifs function in concert with the desecration of sacred space to signal the seriousness of the proceedings. Loftur ultimately fails in his endeavour and dies a horrible death because of it. Evil though he clearly is, even Loftur seems to come to a moral line he is not willing to cross. After he has failed to get the grimoire from Gottskálk, Loftur says, "Rankaði ég fyrst við mér pegar svo langt var komið að hefði ég farið einu særingarstefi lengra pá mundi kirkjan hafa sokkið, og pað var pað sem hann ætlaðist til" (I came to my senses when, if I had chanted one incantation more then the church would have sunken into the ground, and that was what he [the Devil] intended all along). ${ }^{14}$ This story again depicts a high-stakes conflict that, if lost, could result in the loss of both the combatant's eternal soul and the presence of sacred space in the community.

Nor are the spatial and ritual elements of "The Stupid Boy and the Devil" recent additions to Icelandic cultural memory. The fourteenth-century family saga Bárðar saga Snæfellsáss includes a strikingly similar contest between a priest named Jósteinn and an evil king Raknar, who was buried alive with five hundred men. During the assault, Raknar tries to entice the priest to come with him, but the priest remains fixed in his position:

Mörg fádæmi sýndust honum, bæði troll ok óvættir, fjandr ok fjölkunnigar pjóðir. Sumir blíðkuðu hann, en sumir ógnuðu honum, at hann skyldi pá heldr burtu ganga en áðr. Par póttist hann sjá frændr sína ok vini, jafnvel Óláf konung með hirð sinni, ok bað hann með sér fara. Sá hann ok, at Gestr ok hans félagar bjuggust ok ætluðu í burt ok kölluðu, at Jósteinn prestr skyldi fylgja peim ok flýta sér í burt ... Ekki gaf prestr um petta, ok hvat

and January 13, 1915 iterations of Ísafold, a pdf copy of which can be found at https://timarit. is/page/3951352\#page/n1/mode/2up and https://timarit.is/page/3951358\#page/n1/mode/ 2 up. The fascination with Galdra-Loftur is due in no small part to the efforts of Skúli Gíslason, who edited and added a literary quality to existing oral accounts of Loftur. It is Skúli's work that we have in Jón Árnason's collection, and it is indeed a majestic retelling of Loftur's story. Of Skúli's effort, Einar Ólafur Sveinsson says, "it is as if a folk-legend is on the way to becoming something more sophisticated; one might perhaps call it a myth" (Folk-Stories of Iceland, 212). Einar Ólafur Sveinsson's discussion of Galdra-Loftur stories (Folk-Stories of Iceland, 207-13) is drawn largely from Hannes's study.

12 Again, a historical figure, bishop of Hólar 1497-1520, Gottskálk Nikulásson was rumoured to be especially cruel and to have magical ability.

13 See Heinrich Institoris, Malleus Maleficarum, trans. and ed. Christopher S. Mackay, 2 vols. (Cambridge: Cambridge University Press, 2006), 79 A-B and 96D.

I4 JÁ 1:574. 
undrum sem hann sá, eða hversu ólmliga pessir fjandr létu, pá kómu peir pó aldri nær presti sakir vatns pess, er hann stökki. ${ }^{15}$

Many marvels appeared to him - both trolls and evil beings/creatures [óvættir], fiends and people of the black arts. ${ }^{16}$ Some entreated him, while others threatened him, urging him to go away instead. He thought that he saw his family and friends there, and even Óláfur the king [whom Jósteinn serves] with his bodyguard, ${ }^{17}$ and asked him to come with him. He also saw that Gestur and his companions were making ready and intended to leave and called out that the priest Jósteinn should follow them and hasten away ... The priest did not give in to that, and no matter what wonders he saw or how dreadfully these fiends acted, they could never come near the priest on account of the [holy] water that he sprinkled.

The sprinkling of holy water connects the contest between the priest and Raknar with ritual aspersion and baptism, while the spatial element has gone from a church to a burial mound. Though the later narrative replaces Raknar with the Devil and the burial mound with a church, the sinister quality of this evil foe remains evident in the postReformation story of the stupid boy. Ritual and sacred space furthermore serve an important cultural function as a response to evil. The ritual element-aspersion with holy water in Bárðar saga, Holy Communion in "The Stupid Boy"-is fundamental to the fight against evil. Simply put, Christian ritual keeps us safe.

The role of space is less clear. The group that went with Jósteinn has struggled to open a burial mound in which Raknar was put to rest, but after the party toils each day to dig, the mound mysteriously fills itself each evening. Only by standing his ground through the night, relying on his ritual and remaining unmoved, can Jósteinn overcome the magic that thwarts their efforts. While there is no threat in Bárðar saga of the burial mound sinking into the ground like the church (F941.2), that may be because, as a burial mound, it is already in the ground. In fact, Sandis Laime has shown that, in Latvia, F941.2 (Church Sinks Underground) became associated with places in the landscape featuring hillforts and stone gravesites that were assumed to have an ancient, pre-Christian origin. ${ }^{18}$ Something similar may be happening with F941.2 in Iceland, where nineteenth-century narratives such as "The Stupid Boy and the Devil" and the Loftur narrative transform the sacred landscape of the context to match F941.2. In the

15 Bárðar saga Snæfellsáss, 295-355; Íslendingasögur, 3 (Reykjavík: Hrappseyjarprent h.f., 1946), 349-50.

16 Sara M. Anderson translates fjölkunnigar pjóðir here as "fairy folk," which has much to be said in its favour. I avoid connotations with "fairy" here because the etymology of the word fjölkunnigar, and the context of this quotation, does not quite seem to support the deep connotation of the "fairy." See Anderson's translation of the saga in The Complete Sagas of the Icelanders, ed. Viðar Hreinsson, 6 vols. (Reykjavík: Leifur Eiríksson Publishing, 1997), 2:237-66 at 263.

17 I prefer "retinue" here over Anderson's preference for "court," which to me connotes something different. My translation and Anderson's are otherwise largely the same. See Anderson, "Bard's Saga," 263.

18 Laime, "The Place Valence Approach," 84-86. 
nineteenth-century stories, what was once the underground burial mound of Bárðar saga is no longer the site of the conflict but rather the place into which the church sinks if the conflict goes terribly wrong.

Finally, even though the Bárðar saga episode predates the Lutheran mentality described by Oberman, the medieval text does contain a sense of the cosmic war fought by Christianity. To see it, however, it must be noted that the episode from Bárðar saga takes place at the heart of a conversion narrative that occupies the second half of the saga. Gestur, who ultimately leads the party against Raknar, converts to Christianity because of his own experience struggling against the evil king, and while the latter is not said to be the Devil, he is clearly an agent of evil.

Returning to the question of why the stupid boy gets to keep his cleverness, we find that an understanding of space and ritual illuminates something of the religious and cultural pressures upon ATU 330, M216.1, and other international influences in medieval and post-medieval Northern Europe. In contrast to the Devil figures in ATU 330, M216.1, and other narratives about defeating him-in which the devils are defeated by cleverness-here "The Stupid Boy and the Devil" and the medieval narrative Bárðar saga both use space and ritual to act out the skirmish between good and evil as a part of the cosmic war between God and the Devil. The once-stupid boy may have been able to keep his cleverness in the end because he earned the right to do so: Had he lost, he would have forfeited his soul; since he won, his spoils of war are the cleverness offered by the Devil to begin with. ${ }^{19}$

A more difficult question to answer is what, exactly, Sæmundur fróði Sigfússon is doing in this story at all. Based on the above discussion of ATU 330 and M216.1, Sæmundur appears to be an unnecessary complication. M216.1 states that the Devil helps a man become a priest, but when the man becomes a priest, he has learned enough to save himself from the Devil-a kind of ironic rite of passage for the man-becomepriest. It is true that the Finnish variant also includes a priest, but he seems to have no particular identity. In fact, of the unnamed priest in the Finnish variant of this story, E551, Elli-Kaija Köngäs and Pierre Maranda say, "It is obvious that it does not matter structurally who fools the Devil and by what means." ${ }^{20}$ That might be true about the Finnish variant, but it is certainly not true for the Icelandic variant. Not only is the priest named, but he is one of the most famous literary, historical, and legendary figures that Iceland has ever known.

To understand Sæmundur's presence in the tale, we must trace the history of both Sæmundur fróði Sigfússon and stories about him.

19 Similar uses of space occur in the previously discussed tale of Galdra-Loftur, though to a worse end. Skúli's version of the tale nonetheless reflects many of the important trends concerning spatial and ritual opposition to the evil forces that oppose Christianity noted here. See above for more on this point (105-8).

20 Elli-Kaija Köngäs and Pierre Maranda, "Structural Models in Folklore," Midwest Folklore 12 (1962): 133-92 at 171, www.jstor.org/stable/4317987. 


\section{The Folk Legacy of Sæmundur fródi}

By the time "The Stupid Boy and the Devil" was recorded in the mid-nineteenth century, stories of Sæmundur fróði as a galdramaður-in fact, the prototypical galdramaðurwere well established. Before becoming a prominent fixture in Icelandic folklore, Sæmundur fróði was first a historical personage who lived from 1056 to 1133 and was well respected as a historian and otherwise learned man. Sæmundur fróði ${ }^{21}$ has always been close to the centre of Icelandic cultural and literary history (even when he perhaps ought not to have been). ${ }^{22}$ He was apparently so respected a historian during his time that Ari Porgilsson submitted his Íslendingabók to Sæmundur for review, and Ari and other writers cite Sæmundur as an authority for historical information. ${ }^{23}$ Attributions of literary achievement to Sæmundur have little potency now, but during the sixteenth and seventeenth centuries, when many of the galdramaður tales about him would have been circulating for centuries, the cultural memory of Sæmundur's prowess as a writer and poet were alive and well. ${ }^{24} \mathrm{He}$ was, for example, presumed to have written the Poetic $E d d a$, and even today we may see this work referred to as the Sæmundar Edda. ${ }^{25}$ Even Jón Árnason believed that Sæmundur was the poet responsible for the moving thirteenthcentury poem "Sólarljóð" (The Lay of the Sun). ${ }^{26}$ Sæmundur's cultural status in both medieval and post-medieval Iceland afforded him the sympathy of the audiences of post-medieval folktales, so that from the start he would have been rather impervious to whatever criticisms came his way as a result of some of his more questionable dealings with magic as recorded in some narratives. The later folk tradition certainly maintains the sentiment, if not the wording, displayed first in Jóns saga Helga (early thirteenth century), which introduces Sæmundur as "bann mann er verit hefir einnhverr mestr Guðs kristni til nytsemðar á Íslandi" (that man who has been one of the most useful to God's kingdom in Iceland). ${ }^{27}$

2I Both Jón Hnefill Aðalsteinsson and Terry Gunnell have contributed extensive studies of the origins and development of folktales about Sæmundur fróði (Gunnell, "Return of Sæmundur"; Jón Hnefill Aðalsteinsson, "Sæmundr fróði"), to which I will refer regularly in this chapter. Halldór Hermannsson's 1932 study of Sæmundur and his cultural and literary context remains an invaluable source on the subject: Sæmund Sigfússon and the Oddaverjar, Islandica XXII (Ithaca: Cornell University Library, 1932), especially 33-36, for a discussion of Sæmundur's career as a historian.

22 As is well known, Sæmundur was wrongly given credit for the composition of several important medieval texts.

23 For Ari's appeals to Sæmundur's authority, see Íslendingabók: Landnámabók, ed. Jakob Benediktsson, Íslenzk Fornrit 1 (Reykjavík: Hið Íslenzka Fornritafélag, 1968), 3 and 16-17. Note also Siân Grønlie's comments in "The Book of the Icelanders," in Íslendingabók, Kristni saga: The Book of the Icelanders, The Story of Conversion, trans. Siân Grønlie (London: Viking Society for Northern Research, 2006), nn. 2 and 88.

24 Halldór Hermannsson, Sæmund Sigfússon, 36-37.

25 Halldór Hermannsson, Sæmund Sigfússon, 36-37.

26 JÁ 1:475.

27 Sæmundar páttr, in Biskupa Sögur 1, ed. Sigurgeir Steingrímsson, Ólafur Halldórsson, and Peter Foote, Íslenzk Fornrit 15 (Reykjavík: Hið Íslenzka Fornritafélag, 2003), 339. 
Regarding his connection to "The Stupid Boy and the Devil," it is interesting to note that medieval sources depict Sæmundur getting himself into a bind similar to that of the boy in "The Stupid Boy and the Devil." The medieval Icelandic text Jóns saga Helga (which was probably a translation of a lost Latin original) gives an account of Bishop Jón Ögmundarson (1052-1121) - the first bishop of the episcopal see at Hólar in the north of Iceland-going to retrieve Sæmundur from somewhere in Europe. ${ }^{28}$ The earliest version of Jóns saga Helga says only that Sæmundur had gone abroad and not been heard from in a long time, but Jón discovers his location and brings him back home. A later version (late thirteenth-/early fourteenth-century) goes into much more detail, stating that Sæmundur has been studying with an astrologer who teaches "mysterious" arts. It is likely that the medieval story of Bishop Jón and Sæmundur fróði was moulded after a similar twelfth-century account of Gerbert of Aurillac (who later became Pope Sylvester II), found in William of Malmesbury's Gesta regum Anglorum, ${ }^{29}$ which predates the earliest versions of Jón's vernacular vita (ca. 1300). ${ }^{30}$ Even though the moral quality of Sæmundur's mysterious learning is ambiguous in Jóns saga Helga, in this original story about Gerbert there is no mistaking the morality. While with the Saracens, Gerbert learned many things, including how "to summon ghostly forms from the nether regions, everything, in short, whether harmful or healthful, that has been discovered by human curiosity."31 When Gerbert absconds with a book that belongs to his Saracen master, he summons the Devil to help him escape. The text is also clear that Gerbert meets a horrible end because of his dealings with the Devil and forbidden arts. ${ }^{32}$ An important contrast between William of Malmesbury's narrative about Gerbert and the medieval Icelandic variation is, as Jón Hnefill Aðalsteinsson suggests, that the medieval saga writer appears to see no moral conflict between learning these mysterious arts and the Christian church service Sæmundur begins immediately upon his return to Iceland, ${ }^{33}$ but it should at least be clear that Jón is concerned about Sæmundur, wants him to leave his mysterious teacher and come home to Iceland, and that Sæmundur agrees.

Though it is true, as Jón Hnefill observes, that the medieval saga writer does not offer direct moral judgment of Sæmundur's motives, there is strong indication of an internal

28 Sæmundar páttr, 339-43. See commentary in Peter Foote's introduction to Jóns saga Helga, in Biskupa sögur 1, cclxvii-cclxxi. See also Ásdís Egilsdóttir, "From Orality to Literacy: Remembering the Past and the Present in Jóns saga Helga," in Reykholt som makt- og lærdoms-senter í den Islandske og Nordiske kontekst, ed. Else Mundal (Reykholt: Snorrastofa, Menningar og Miðaldasetur, 2006), 215-16, for a discussion of the manuscript traditions for Jóns saga Helga.

29 See William of Malmesbury, Gesta regum Anglorum, ed. and trans. R. A. B. Mynors, R. M. Thomson, and M. Winterbottom, 2 vols., Oxford Medieval Texts (Oxford: Clarendon, 1998-99), 1:279-95.

30 For information on Jóns Saga Helga, see Jóns Saga Hólabyskups ens Helga, ed. Peter Foote, Editiones Arnamagnæanæ, Series A, vol. 14 (Copenhagen: Reitzel, 2003).

31 William of Malmesbury, Gesta regum Anglorum, 1:280-81.

32 William of Malmesbury, Gesta regum Anglorum, 1:294-95. Also referenced in Jón Hnefill Aðalsteinsson's “Sæmundur fróði," 123.

33 Jón Hnefill Aðalsteinsson, "Sæmundur fróði," 124. 
struggle within the Sæmundur of Jóns saga Helga. There are two significant indicators of this struggle. First, when Jón finds the wayward Sæmundur, it is said that the latter is so deep in his studies of dubious lore that "hann týndi allri peiri er hann hafði á œskualdri numit ok jafnvel skírnarnafni sínu" (he had lost everything he had learned in his childhood, even his baptismal name). ${ }^{34}$ Jón Hnefill reads this passage as reflecting the possibility that the historical Sæmundur left to study at such an early age that he forgot much of what he knew of Iceland as a child. There may be a historical element to this passage, but the detail about the loss of his baptismal name (skírnarnafni) is also suggestive beyond any historical connection: The loss of a baptismal name indicates something about the spiritual standing of an individual. If the baptismal name has been forgotten, then the spiritual function of baptism may also be lost. In other words, Sæmundur's journey to acquire mysterious knowledge has taken him so far outside Christendom that he has forgotten not just his name but also his Christian identity. This loss of identity is also suggestive of a dramatized rite of passage, in which neophytes are sometimes characterized as forgetting or losing their own name during the liminal stage. As Edward Berry describes this function, "the liminal phase can be characterized as one of confusion, testing, and education, although 'confusion' is too trivial a word for the fundamental dislocation of self sometimes experienced ... this disorientation occurs in such activities as dying symbolically; losing one's name, language, and customary diet; disguising oneself, or mutilating or painting one's body."35 This "confusion" and "education" fit well with Sæmundur's experience here, for he has lost his identity, become confused, so to speak, for the purpose of acquiring a rather unique education. There may even be cause to view his psychological state as "disguised" or "mutilated," for in place of his baptismal name Sæmundur is using the name Kollur, which could mean "head,"36 as Jón Hnefill translates it, though it may also be read as an abbreviated version of kölski (devil). ${ }^{37}$

The nature of Jón's rhetorical rebuttal of Sæmundur's dubious name points to a second reason to perceive an internal struggle in Sæmundur: Jón does not merely correct him but rather answers "af gipt heilags anda" (with the gift of the Holy Spirit), ${ }^{38}$ which suggests a kind of spiritual rebuke or even exorcism of Sæmundur. When Sæmundur acquiesces to Jón’s entreaties, he says, “Vera má at sǫnn sé saga pín. Ok ef svá er, pá mun finnask í túninu í Odda hóll nọkkurr, sá er ek lék mér jafnan við” (It may be that what you say is true, and if it is, then a certain hill will be found in the field at Oddi where I used to play). ${ }^{39}$ Again, there is something about this scene that reminds us of a liminal phase for Sæmundur. As Turner puts it, "during the liminal period, neophytes are alternately

34 Sæmundar páttr, 339.

35 Edward Berry, Shakespeare's Comic Rites (Cambridge: Cambridge University Press, 1984), 4.

36 Jón Hnefill Aðalsteinsson, "Sæmundur fróði," 119.

37 See Sæmundar páttr, 339n7 and references there.

38 Sæmundar páttr, 339-40.

39 Sæmundar páttr, 339. 
forced and encouraged to think about their society, their cosmos, and the powers that generate and sustain them. Liminality may be partly described as a stage of reflection." ${ }^{40}$ This is just the sort of reflection affecting Sæmundur here. He feels a call to return to his childhood environment and retrieves the memory of himself within his native space at his home at Oddi. Spatial consideration of this story thus produces a similar binary to those observed in previous chapters: just as Auður's Christian lands (and her church) opposed the land that Gullbrá co-opted, and just as the Christian church opposed the elf church in Tungustapi, here too the hill at Oddi opposes a school of "mysterious arts" where Sæmundur has forgotten who he is and where he comes from. The internal struggle, then, is both spiritual (as he recalls his baptismal name) and spatial (as he recalls his childhood home). When his Icelandic, Christian origins win out, the internal struggle is resolved and he is Kollur (devil) no longer. What follows in the medieval text, Jóns saga Helga, is an outward reflection of the inward struggle which Sæmundur has already won: he must escape from his master and return to his home at Oddi, Iceland.

The connections between "The Stupid Boy and the Devil" and these early stories about Sæmundur fróði may not be obvious, but they are present even in the medieval version of Sæmundur's quest for "mysterious" knowledge. In both, we see a young man who seeks knowledge in a way that presents an internal struggle. For the boy, it is a deal with the Devil; for Sæmundur, it is the loss of his Christian identity and the remembrance of his childhood home. Likewise, both the stupid boy and Sæmundur are unable to resolve their struggles on their own. The stupid boy receives help from Sæmundur, while Sæmundur receives help from Bishop Jón Ögmundarson. Finally, in both Jóns saga Helga and "The Stupid Boy and the Devil," the principal characters retain what they have learned even after their ordeals. The long development of folk stories about Sæmundur fróði bears out the connection even further. In post-medieval folklore, Sæmundur stories have become associated with the well-known legend ML 3000, the Black School, in which the teacher at the school is the Devil himself. ${ }^{41}$ The final stage of Sæmundur's story in Jóns saga Helga-his life after he returns to his home at Oddi, Iceland-likewise bears an important connection to "The Stupid Boy and the Devil." In order to understand these connections, however, we must consider the development of Sæmundur stories from the medieval to the post-medieval period.

40 Victor Turner, "Betwixt and Between: The Liminal Period in Rites of Passage," in Betwixt \& Between: Patterns of Masculine and Feminine Initiation, ed. Louise Carus Mahdi, Steven Foster, and Meredith Little (La Salle: Open Court, 1987), 14.

4I Other stories represent the magicians' acquisition of forbidden knowledge in various ways. Instead of going to the Black School to learn magic, the priest Eiríkur of Vogsós (1638-1716) learns his dark arts from a magic book. The story of the galdrabók is traceable in Iceland at least as far back as Árni Magnússon's Sæmundur stories (ca. 1700), though there it is more or less an anecdote about a magical expedition gone wrong (JÁ 1:473-74). The folk figures (here they are Sæmundur, his friend Jón, and Jón's mistress) get word of a magic book buried in the graveyard at Oddi and try to raise the magician holding it in order to steal it. After raising all the ghosts in the cemetery, Jón's mistress, who had snuck in to see the show, becomes scared and screams, prompting Jón to ring the bell early and Sæmundur to lose the book. 


\section{Ministration and the Post-Medieval Sæmundur Stories}

After the medieval period, the narrative about Sæmundur and his escape from the astrologer drops out of written sources for more than three hundred years. The fact that it resurface again in 1701, when renowned Icelandic scholar Árni Magnússon began collecting accounts of Sæmundur fróði, is a testament to the vitality of the story in oral tradition in Iceland..$^{42}$ Later still, around 1850, Jón Árnason collected even more stories about Sæmundur fróði as a magician, adding further stories about more than thirty magicians, eleven of whom held some position in the Church. ${ }^{43}$ Terry Gunnell argues that the story recorded in Jóns saga Helga, which was clearly literary in style, ${ }^{44}$ must have entered (or re-entered) oral tradition and there became fully shaped over the next few hundred years. ${ }^{45}$ Of the connection between the medieval account of Jón and Sæmundur and the post-medieval stories about Sæmundur, Terry Gunnell suggests that the

late thirteenth-/early fourteenth-century account has little to do with the later, more well-known legends concerning Sæmundur's return [to Iceland] which are found in Jón Árnason's Íslenzkar pjóðsögur og ævintýri, apart from the central ideas that Sæmundur Sigfússon studied in a Northern European school under the guidance of a powerful Master who taught him "mysterious" arts (including "astronomian"); that Sæmundur's master did not intend him to leave, and thus needed to be tricked; and that Sæmundur (originally with Jón Ögmundarson) returned home to Iceland (by sea) to be awarded the position of the priest at Oddi in southern Iceland. ${ }^{46}$

Gunnell's point here is perhaps nowhere clearer than in the stories of what happens after Sæmundur returns to Iceland from the Black School. The medieval Jóns saga Helga offers a concise but complete description of the ministries of both Jón and Sæmundur upon returning to Iceland, saying that they both served their community humbly and well and relied upon good Christian doctrine to support and protect the Church, and gave wise counsel to whoever needed it. ${ }^{47}$ This description in the medieval tale of Sæmundur's and Jón's service to their churches is a key factor in the perception of both men. It is a testament to their fulfilment of their vocations as priests, and it shows that their various trials and travels contributed something not just to their own personal edification but also to their local Icelandic communities. It is also, from a literary and narratological perspective, a key feature in the completion of the dramatized (possibly latent) rite of passage mentioned above, since the neophyte has now completed the

42 Recorded by Bishop Björn Porleifsson and now found in AM 254 8vo. Terry Gunnell notes that Bishop Björn was from Oddi (where Sæmundur was priest for most of his career) and would likely have picked up stories about Sæmundur that were still alive in oral tradition during the seventeenth century. See Gunnell, "Return of Sæmundur," 90.

43 Jón Hnefill Aðalsteinsson, "Sæmundr fróði," 118. See also JÁ 1:468-599 and 3:490-622.

44 Jón Hnefill Aðalsteinsson, "Sæmundr fróði," 121.

45 Gunnell, "Return of Sæmundur," 109.

46 Gunnell, "Return of Sæmundur," 88.

47 Jóns saga Helga, 190. 
reincorporation stage of the rite and has returned to his home space to serve his community as a transformed, fully initiated member of the society.

In stark contrast to this description from the medieval narrative, the post-medieval stories about Sæmundur's life after his return describe his contests with a (typically) weak, ineffectual devil. As Jón Hnefill Aðalsteinsson concludes,

In the folk tales from about 1700 and 1850, there are no particular accounts concerning Sæmundur's priesthood or his work in the service of the church. These legends commonly mention that he was the priest at Oddi, but that is not seen as being of any real importance. Most accounts of Sæmundur concern his confrontations with the devil. ${ }^{48}$

Should Sæmundur's and Jón's ministries in Iceland be absent from the post-medieval tales, as Jón Hnefill's conclusions here suggest, it would signal a notable departure from the perception of Sæmundur in the medieval narrative.

I would argue, however, that an assessment of these post-medieval stories about Sæmundur show more nuance than Jón Hnefill allows. It is true, as he attests, that many of the post-medieval stories about Sæmundur's life after his return to Oddi depict his confrontations with the Devil. These narratives tend to be fairly typical international motifs ${ }^{49}$ that follow the view of a devil that is more or less a pathetic figure. ${ }^{50}$ Regarding Sæmundur's service to his church and community, however, the important aspect of these stories is not just that he defeats an ineffectual devil, but that in many of these stories he does so specifically in service to people of his church and community. For instance, the story "Kölski smíðar brú á Rangá” (The Devil Builds a Bridge over the River Rangá) ${ }^{51}$ follows a common international motif, G303.9.1.1 (The Devil Builds a Bridge), but to grasp the full meaning of the tale we must read beyond the motif. According to this short tale, Sæmundur has the Devil build the bridge, "pví oftsinnis var örðugt yfir ána að komast, einkum peim er til Odda skyldu tíðir sækja" (because it was often difficult to cross the river, especially for those who wished to go to Oddi to attend church). ${ }^{52}$ The means by which Sæmundur serves his congregants has become entangled with international folk motifs, but he is still tending to the needs his congregation. ${ }^{53}$ Likewise, in "Púkinn og

48 Jón Hnefill Aðalsteinsson, "Sæmundr fróði," 130.

49 Gunnell asserts that "The story of Sæmundur has evidently moved out of an international hagiographic tradition and shifted into an international folkloristic tradition. What is especially interesting, however, is the way in which the Icelandic legends deviate from their close relations in neighbouring countries" ("Return of Sæmundur," 89). That the tales were drawn back into the folk tradition suggests they had some usefulness to the folk belief, and that Icelanders developed the tales in their own unique way suggests that the usefulness was in some way shaped by the Icelandic mythic consciousness. All of this supports the approach to pagans as discussed in the Introduction.

50 Jón Hnefill, “Sæmundur fróđi," 130.

5I JÁ $1: 472$.

52 JÁ 1:472; my italics.

53 The theme of a magician-priest using knowledge of magic to provide a service is developed more fully in the folk figures of Eiríkur of Vogsós and Hálfdán of Fell. "Eiríkur frelsar konur frá 
fjósamaðurinn" (The Demon and the Cowherd), ${ }^{54}$ Sæmundur enlists the aid of a demon (púkinn) to teach a moral lesson to a cowherd with a vulgar tongue. ${ }^{55}$ Sæmundur's actions here may not qualify as teaching good Christian doctrine (kenningar helgar $)^{56}$ as he is described doing in Jóns saga Helga, but the Sæmundur of later tales is teaching a moral lesson nonetheless. And when Sæmundur makes the Devil lick up cow dung in the story "Kölski mokar Oddafjósið” (Kölski Mucks Out the Cowshed at Oddi) ${ }^{57}$ it is because the Devil has blocked the door with the dung and Sæmundur needs to get to his church service on time. Further, we may look at several tales in which Sæmundur defeats the Devil for the purpose of saving someone who has foolishly agreed to exchange their soul for something. For example, in "Vatnsburður Kölska" (The Devil Carries Water), ${ }^{58}$ Sæmundur tricks the Devil to help a housemaid in Oddi who has rashly made a deal with him; in "Fjósamaðurinn í Odda"59 (The Cowherd at Oddi), Sæmundur saves a foolish cowhand from eternal damnation by lending him a piece of clothing, which the Devil will recognize and thus abandon the man's soul. ${ }^{60}$ It is of course in this last category that we can place "The Stupid Boy and the Devil," 61 in which a boy would have lost his soul in exchange for the gift of cleverness, had Sæmundur not instructed him on how to escape. Finally, we find moments where Sæmundur's love and concern for those under his care is impossible to ignore. One folktale states: "Sæmundur hafði tekið meybarn til fósturs

óvættum" (Eiríkur Frees Women from Ogres) includes three tales, and here I refer her to the second (JÁ 1:556-59). Eiríkur helps a young, promising man find his lost wife, who has been abducted by ogres. Likewise, in "Málmeyjarkonan" (The Woman of Málmey; JÁ 1:501), Hálfdán of Fell attempts a similar rescue but with a less happy end. Both Eiríkur and Hálfdán serve a similar guardianship function to that of Sæmundur here.

54 JÁ 1:481.

55 Eiríkur of Vogsós also has a proclivity for instruction. In "Hestastuldurinn" (The Horse Theft; JÁ 1:548-49), two young boys take two of the priest Eiríkur's horses without permission, something that Eiríkur strictly forbids. As they try to escape, the boys realize that they are stuck to the saddles and the horses are riding fast back to Vogsós and Eiríkur. One boy decides to cut himself out of the seat of his pants and thereby escape the wrath of the magician, but the other boy panics and is caught. In the end Eiríkur scolds the boy who panicked, but says of the boy who cut himself out of his trousers that he would make a worthy pupil because of his resourcefulness. See also "Handbókin" (The Handbook; JÁ 1:545-46), which is an Icelandic example of the common tale of a young boy who opens a sorcerer's magic book without permission (a variant of ATU 325*, The Sorcerer's Apprentice) and must deal with the consequences. Eiríkur finds out, he praises the boy for his ability (rather than chastising him for his disobedience), and takes him on as a pupil. In another tale, "Sakamaðurinn" (The Convict; JÁ 1:559), the same boy aids Eiríkur in overcoming a sending that has been sent to kill the magician.

56 Jóns saga Helga, 190.

57 Já 1:473 and 481.

58 JÁ 1:470.

59 JÁ 1:473.

60 JÁ 2:473.

6I JÁ 2:483-84. 
af fátækum manni; honum pótti ósköp vænt um hana og unni henni svo mikið at hann mátti ekki af henni sjá né við hana skilja" (Sæmundur had taken in the daughter of a poor man as his foster daughter; she was extremely dear to him, and he loved her so much that he never took his eyes off her nor wanted to be separated from her). ${ }^{62}$ Even though the purpose of this story "Sæmundur á banasænginni” (Sæmundur on His Deathbed) is not necessarily to highlight Sæmundur's service to his community, this description of his affection for his foster daughter shows the selfless love one would expect from someone who possesses great compassion and concern even for those who are less fortunate.

\section{Sæmundur's Death and Accountability}

The end of Sæmundur fróði's life goes more or less unaccounted for in the medieval text Jóns saga Helga. With the exception of a statement indicating that he (and Jón) lived a long and prosperous life, there is no indication of how Sæmundur dies or the condition of his soul in his final moments (though we might assume the best). This absence, once again, is a notable departure from the source text for the Sæmundur story, the story of Gerbert/Silvester in William of Malmesbury's Gesta regum Anglorum. This is the second important departure from William of Malmesbury. We may remember that the medieval Icelandic narrative also does not include any direct moral assessment or condemnation of Sæmundur, while William of Malmesbury's text certainly does make moral judgment of Gerbert, Sæmundur's counterpart. The absence of moral judgment and the absence of an account of Sæmundur's death may not be unconnected, since Gerbert's death scene is clearly invested in his moral judgment and accountability. According to William of Malmesbury, when Gerbert of Aurillac (Pope Sylvester II) fell mortally ill, his final moments went as follows:

Calling, therefore, the cardinals together, he lamented his crimes for a long space of time. They, being struck with sudden fear were unable to make any reply, whereupon he began to rave, and losing his reason through excess of pain, commanded himself to be maimed, and cast forth piecemeal, saying "Let him have the service of my limbs, who before sought their homage; for my mind never consented to that abominable oath." ${ }^{\prime 6}$

The passage does not specify what exactly follows, but it can be assumed that he died immediately following his rant. There are several key elements of this passage to bear in mind. First, Gerbert makes a confession but receives no absolution because the cardinals present are "struck with sudden fear." Second, the antecedent of "him" who wants Gerbert's limbs is clearly the Devil with whom he made a deal long ago. Third, the meaning behind the phrase "my mind never consented to that abominable oath" is puzzling, but at least the narrator, William of Malmesbury, is convinced of his guilt. In an earlier allusion to Gerbert's death, William states, "The singular choice of his death confirms me in the belief of his league with the devil; else, when dying ... why should he,

62 JÁ 1:485.

63 William of Malmesbury, Gesta regum Anglorum, 181. 
gladiator-like, maim his own person, unless conscious of some unusual crime?" ${ }^{64}$ William of Malmesbury views this final torment of Gerbert's life as an indication of his oath to the Devil. Gerbert's mind may not have consented, but it is certainly broken, which leads to his demands that his body be mutilated in the most gruesome way possible.

It is telling, then, that the medieval story of Sæmundur, Jóns saga Helga, offers neither moral judgment of Sæmundur's pursuit of mysterious arts nor a final death scene, which may have provided an indication of the condition of Sæmundur's eternal soul, as William of Malmesbury's source text does for Gerbert. It is as though the medieval Icelandic writer wanted to keep things simple. Rather, as I suggested earlier, Jóns saga shifts Sæmundur's pursuit of mysterious arts away from a matter of culpability to a matter of internal struggle, and then takes time to illustrate Sæmundur's uncommonly good service to his community and church after his ordeal. The presence of an internal struggle instead of a moral judgment in Jóns saga affords the medieval narrative the freedom to show Sæmundur's service to his church and the community at Oddi in such a way that need not be complicated by any question of his motives.

It is further telling that post-medieval tales of Sæmundur include both an account of Sæmundur's service (though distorted into accounts of defeating the Devil) to his church and community at Oddi and an account of his death. Correspondingly, the prospect of moral accountability upon Sæmundur's deathbed also more closely resembles the deathbed of Gerbert than anything we see in Jóns saga Helga, though it has a conclusion quite different from what we see in William of Malmesbury's work. One story of Sæmundur collected about 1850 describes the final moments of his life: ${ }^{65}$ Sæmundur has a premonition of his death and asks his beloved foster daughter to sit at the foot of his bed through the night. She recognizes that he is anxious about whether he will go to Heaven or Hell when he dies, and Sæmundur tells her to watch for signs of what might occur. Later in the night, she sees a host of demons first try to tempt him into doing some evil, which Sæmundur resists, and then the demons begin to threaten him. This too fails, and a swarm of midges then attack Sæmundur and sting him mercilessly until a ray of light escapes his mouth, which his foster daughter perceives to be his soul flying off to Heaven.

Even though any direct transmission between the account of Gerbert's death in William of Malmesbury's work and this post-medieval tale seems quite unlikely, a comparison of the two texts remains useful because it gives us a sense of the development of this story over the centuries in Iceland. Both Sæmundur and Gerbert are concerned about the state of their eternal soul upon their deathbed, and both suffer torments during their final moments. While Gerbert ultimately confesses of all his wrongdoings, Sæmundur does not, and yet it is Gerbert who ends up in Hell while Sæmundur goes to Heaven. The fact that Gerbert confesses but does not receive forgiveness seems to have a ritualized implication as well. The cardinals, we may recall, are so stunned by

64 William of Malmesbury, Gesta regum Anglorum, 175.

65 JÁ 1:485-86. 
what Gerbert has said that they cannot speak. They would have had the responsibility of performing the last rites, but no one seems able to perform the ritual.

It seems that through the long development of the Sæmundur stories, the communities that sustained these narratives through oral transmission from the medieval to the post-medieval period grew unsatisfied with the absence of some sort of deathbed moral accountability. The point is driven home by the fact that other magicianpriests have similar deathbed experiences. ${ }^{66}$ Einar Ólafur Sveinsson seems to take these tales lightly, suggesting that these magicians "are a little worried about their eventual salvation, and piously coloured stories exist on this theme." ${ }^{67}$ I suggest rather that the crisis of faith and the prospects for the afterlife would have resonated with an audience who, as discussed earlier, viewed the last moments of life as a testament to the prospects of the soul after death, so much the more so if the dying person is connected with both malefic magic, on the one hand, and Christian ministration on the other. In life, the magicians call upon magical prowess to fight against supernatural forces.

In death, however, that assistance is lost to them, and they suffer-as Gísli Súrsson famously does at the end of his life-from an impotency in the struggle for their souls. In one of his violent dreams Gísli sees two loons fighting, covered in blood, and apparently symbolizing the two dream-women who struggle of Gísli's soul in Gísla saga. The two birds that fight one another in a bloody mess must somehow be connected to Gísli's fylgja (attendant spirit), whose presence often serves as an omen for an impending death. Nothing in Gísli's poetry indicates which bird wins, or indeed which bird is the good and which the bad, ambiguities which further contribute to the uncertainty of Gísli's fate after death. As in the Sæmundur stories, Gísla saga relates a profound anxiety that results from Gísli's impotence throughout the struggle, but the difference between Gísla saga and the later tales is that it gives little indication of what Gísli has done to warrant the struggle for his eternal well-being (it is surely not because he is an outlaw), but we understand precisely why the magicians' welfare hangs in the balance in the post-medieval tales: Sæmundur and the others are being made to answer for their acquisition and usage of black magic. They stand as representatives of both darkness and light, of sinfulness and good intentions, of living an inevitably sinful life and hoping for redemption nevertheless. At the point of death, the tally is taken; the galdramaður

66 See, for instance, "Eiríkur prestur grafinn" (The Reverend Eiríkur Buried), "Sæmundur á banasænginni," and especially "Dauði Hálfdanar prests" (The Death of the Reverend Hálfdan), in which Hálfdán asks his foster daughter to watch over him on his deathbed. She must observe whether the three candles at the head of the magician's bed remain lit through the night. Hálfdan has also placed a ram with a golden fleece under his bed. If the candles remain lit and the ram disappears, then Hálfdan will go to Heaven. Like Sæmundur, Hálfdan is now powerless in the struggle over his prospects in the afterlife, and once again, we see no hint of Heaven's forces there to protect him. Nevertheless, one candle burns through the night and the ram ascends from under the bed and through a hole in the roof. The ram is no doubt a part of folklore descended from the animal fylgjur of earlier legends and lore. When it ascends through the light, Hálfdan's watcher assumes that he has made his way to Heaven.

67 Einar Ólafur Sveinsson, Folk-Stories of Iceland, 202. 
is accountable for the life he has led. This, from the Christian perspective, is the human condition. The galdramaður's death thus serves as a dramatized template for any who face death and the afterlife.

Similar employment of the fylgja motif occurs in post-Reformation Icelandic folktales. In the deathbed tale "Eiríkur Prestur Grafinn" (The Reverend Eiríkur Buried) ${ }^{68}$ the motif of two fighting birds (E756.3, Black and White Birds Fight Over a Man's Soul) reappears, though, this time, the lines are more clearly defined because one is a black bird and the other white (like the fylgjur of piðranda páttr). Eiríkur, one of the subsequent guardian magician-priests to follow Sæmundur, has predicted that the two birds will fight over the right to perch on the roof of the church. If the white bird wins, then things will go well for Eiríkur and he can be buried in the churchyard, but if the black wins, he must be thrown under a cairn (perhaps echoing some remembrance of pagan burial though here it possesses an obviously negative connotation). All this should indicate that these magician-priests are more than just "a little worried about their eventual salvation," as Einar Ólafur suggests.

Jacqueline Simpson says of accounts of magicians on their deathbed that they "dramatize an ambivalent attitude toward magic, which is seen as intrinsically evil, but pardonable if used for good ends." ${ }^{69}$ Jón Hnefill Aðalsteinsson agrees with this assessment, pointing out that over the long development of these Sæmundur stories, Sæmundur is never said to have been charged with using magic. ${ }^{70}$ Simpson and Jón Hnefill make compelling arguments regarding views of magic, yet something about these deathbed stories remains unsatisfying. Sæmundur's deathbed scene is not just a matter of ambivalent attitudes toward magic but also a matter of spiritual condition. It is a matter of the cosmic war in which his soul will be won or lost depending on the outcome of this battle at the end of his life. In the Sæmundur story, just as in "The Stupid Boy and the Devil," demons first try to tempt and then threaten Sæmundur into doing evil. Also like the stupid boy, Sæmundur is victorious. Only, for Sæmundur, this is the final battle, so to speak, the battle that signals to his friends and family whether his soul is won or lost. For this reason, we must wonder how the development of an Icelandic understanding of death and dying might have influenced these stories as well.

Arnved Nedkvitne has conducted a comprehensive study of material and literary evidence for ritual practices in medieval (Christian) Norse society. His work indicates the importance of purification rituals intended to free the individual of their moral shortcomings in preparation for the afterlife. He argues that "the basic and absolutely necessary religious rituals for laymen were felt to be baptism, ... more or less frequent attendance at divine service during one's lifetime, and last rites at the end of life." ${ }^{.11}$ All

68 JÁ 1:565.

69 Simpson, Legends of Icelandic Magicians, 30n16.

70 Jón Hnefill Aðalsteinsson, “Sæmundur fróđi," 129.

7I Arnved Nedkvitne, Lay Belief in Norse Society, 1000-1350 (Copenhagen: Museum Tusculanum Press, 2009), 158. 
of these rituals, most importantly the last rites, required the presence of an ordained member of the clergy, though a deacon could administer shrift (sacrament of penance) if no priests were available. ${ }^{72}$

This concern with the condition of the soul and the direction it will travel in the afterlife are confirmed in later medieval Icelandic literature. Úlfar Bragason mounts a convincing argument that in Íslendinga saga, the centrepiece of the larger compilation Sturlunga saga, saga writer Sturla Pórðarson uses his description of death scenes to mark approval (or disapproval) of the life led by the deceased. ${ }^{73}$ Based upon Úlfar's examination, a character might experience a tranquil death which they predict, prepare for, and await peacefully, as do Guðmundur Arason and Pórður Sturluson (Íslendinga saga, chapter 120). The preparations serve to indicate the piety of the characters at their time of death. ${ }^{74}$ Particularly violent death scenes characterize the dying individual as heroic, as in Sighvatur Sturlason's case (Íslendinga saga, chapter 138).$^{75}$ Finally, the death of Sighvatur's brother, Snorri Sturlason, who faced death largely unprepared (both for the attack that killed him and for the afterlife), might indicate a life of cowardice. ${ }^{76}$

Margaret Cormack's study of death and dying in Icelandic saints' lives further confirms much of this assessment, but literary topoi allow for further clarification of Icelandic perceptions of the end of life. Cormack acknowledges that many of these topoi originate from European saints' lives and other literary sources, but she also surmises that while the Church leadership and scribes would have recognized international hagiographic borrowings, the laity in Iceland are not likely to have been aware of them. ${ }^{77}$ These literary descriptions of deaths indicate a notable concern for the status of the individual's spiritual condition at the time of death. Either immediately before or after death, some (often supernatural) signal indicates whether the deceased or dying will make their way directly to Heaven. Specifically, Cormack notes that medieval accounts of confession or pious gestures can indicate optimism about the ultimate destination of the deceased. ${ }^{78}$ In turn, posthumous miracles (rays of light illuminating the body, for example) not dissimilar to those indicating sainthood might also suggest the good fortune of the recently decease $\mathrm{d}^{79}$ and that consequently they can be buried in consecrated ground. ${ }^{80}$ Finally, it was not uncommon, Cormack observes, that those who

72 Nedkvitne, Lay Belief, 105.

73 Úlfar Bragason, "The Art of Dying: Three Death Scenes in Íslendinga saga," Sacandinavian Studies 63 (1991): 454. I cover this in "Prospective Memory of Death and the Afterlife," 550. See Philippe Ariès, The Hour of Our Death, trans. Helen Weaver (New York: Knopf, 1981).

74 Nedkvitne, Lay Belief, 457.

75 Nedkvitne, Lay Belief, 458.

76 Nedkvitne, Lay Belief, 459.

77 Cormack, "Saints and Sinners," 196.

78 Cormack, "Saints and Sinners," 189.

79 Cormack, "Saints and Sinners," 190-95.

80 Cormack, "Saints and Sinners," 196. 
receive posthumous indications of salvation also suffered from a questionable status in the eyes of the Church at the time of their death. ${ }^{81}$

It seems that variants of confession, piety, and certain literary topoi lived on in post-Reformation stories about Sæmundur fróði. In these tales, Sæmundur, too, has foreknowledge of his death, and he gives a trusted relative or disciple the responsibility of watching over him as he dies. Sæmundur fróði isolates himself from the world as much as he can and instructs the watcher to look for certain signs of his fate after death. As he is dying, the watcher observes demons first try to coax Sæmundur into succumbing to his evil past and then to scare him into it. Whatever magic ability he had in life to combat such evil creatures has left him here, for he endures the attacks much more than he combats them. Next, a host of midges enter the room and begin to devour the Christian magician. At last, a ray of light, presumably his soul, escapes from his mouth, the midges vanish, and the watcher reckons the magician to have gone to Heaven. The struggle that Sæmundur must endure takes a similar structure to that of Gísli's struggle. Just as Gísli is promised by his good dream-woman that he will go to a fair place after death, Sæmundur was told earlier in his life (upon being saved from the Black School of magic by Bishop Jón) that his soul would be free from eternal damnation. But when the time of death has come, the souls of both Gísli and Sæmundur seem to be quite up for grabs. Furthermore, in neither case does there seem to be any indication that any "good" power is there to combat the evil that has come to afflict the dying man; Gísli's good dream-woman is nowhere to be found, and until the very end, Sæmundur has not only lost his ability to fight evil but he is also completely separated from any form of good help; even the watcher does nothing.

These observations lead us to a larger, perhaps more interesting question for the present examination of Icelandic folklore, which is why these stories about defeating the Devil-some of them silly, others perhaps more serious-find a home in the context of Icelandic religious and cultural history. One possibility is that religious development in the country from medieval to post-medieval times may have brought about an unexpected deterioration of the diversity of spiritual guardianship in the country. In medieval Iceland the local priest might have been a possible spiritual guardian-provided he was local enough (and Icelandic enough) to win the trust of the average Icelander-but saints, supernatural sacred spaces, and icons also took up the responsibility of guardianship, facilitating both good fortune and the reversal of bad fortune. The conversion from Catholicism to Lutheranism had a significant impact on all three of these. Margaret Cormack has done the pioneering work on saints' lives and the veneration of saints in Iceland. As she shows, hagiographic elements had to some degree or another long been a part of Icelandic literature, both prose and poetry. Saints' lives were translated into Icelandic from Latin, ${ }^{82}$ and Old Norse poetry took saints as

8I Cormack, "Saints and Sinners," 196.

82 Margaret Cormack, The Saints in Iceland: Their Veneration from the Conversion to 1400 (Brussels: Society of Bollandistes, 1994), 32-34. 
its subject as early as the eleventh century, when poets began to venerate St. Óláfur. ${ }^{83}$ Cormack notes that "readings from saint's legends on their feast days were probably the primary, if not the sole, source of information about them." ${ }^{\prime 4}$ The establishment of feast days was in turn influenced by popular opinion. As Cormack points out, "the saints in whom interest is attested appear to have attained popularity before, rather than after, their feasts were adopted." ${ }^{\prime 5}$ We may deduce from Cormack's observations that legends of the saints' lives were perpetuated by both the Church and the laypeople, entering oral tradition from the pulpit and living on in orality to reinforce church practices. In other words, if the initial and most common means of transmission of information about saints' legends was from the pulpit, orally, then the saints' narratives had a mode of distribution to the literate and illiterate alike. It seems reasonable to think that the popularity of those saints should flourish within the oral tradition, particularly in an environment like Iceland, where we have reason to believe that oral transmission was a vital part of the cultural milieu. ${ }^{86}$ If the stories about saints intermingled with folk stories about other, fantastic guardians, then the cultural memory of the two may also have been intermingled.

In addition to feast days and oral transmission of legends, the veneration of saints involved employing holy relics, taking oaths on saints, pilgrimages, and of course, by prayers, offerings, and fasts. In some cases, such as on feast days, a direct replacement of pagan tradition occurred in a relatively orthodox manner; ${ }^{87}$ at other times oath taking and holy relics seem to have been used in less acceptable ways. In Iceland, holy men employed relics in various capacities, though most were used for healing people or animals, or blessing pools of water, springs, or rivers. ${ }^{88}$ While written narratives offer examples of people doubting the authenticity of relics, though these appear to have been hagiographic opportunities either to reveal the ultimate reality of a miracle, for instance by disproving the skeptic, or to justify the miracle by erudition..$^{89}$ Vows and relics were used together to acquire supernatural aid in both difficult tasks, such as raising the dead, and more menial ones, such as finding lost items. Oaths taken for the benefit of persons

83 Cormack, Saints in Iceland, 41.

84 Cormack, Saints in Iceland, 32.

85 Cormack, Saints in Iceland, 23.

86 For more on the orality and literacy of hagiography, see Evelyn Birge Vitz, "From the Oral to the Written in Medieval and Renaissance Saints' Lives," in Images of Sainthood in Medieval Europe, ed. Renate Blumenfel-Kosinski and Timea Klara Szell (Ithaca: Cornell University Press, 1991), 97-114. In specific relation to Icelandic hagiographical texts, see also Ásdís Egilsdóttir, "From Orality to Literacy," 215-28, especially 216-17.

87 Similarly, Cormack points to a story from Saga Óláfs Tryggvasonar af Oddr Snorrason munk, in which Martin appears to Óláfur and promises him the gift of eloquent speech if Óláfur will give toasts to him in place of the pagan toasts of old.

88 Cormack, Saints in Iceland, 64.

89 Cormack, Saints in Iceland, 65. 
could be small-scale, for the sake of individuals, or on a larger scale, for groups. ${ }^{90}$ of the twenty-nine petitions to saints that Cormack collects from Old Norse narrative texts and annals, ${ }^{91}$ five call for good fortune (two going into battle, one in a struggle with a walrus, one before a journey, and one just after a birth) and six are petitions for the reversal of bad fortune, while eleven are petitions made in dire situations (e.g., ships in a storm or during an enemy attack). Others simply note that vows were made.

After the Reformation, the validity of these guardian figures were called into question. The Communion of Saints no longer implied the ability to offer petitions to saints who had gone on to be with God in Heaven, or to venerated Catholic saints for personal, intimate, local, supernatural assistance. What resulted was a loss of supernatural guardianship at the local level. In Iceland, the timing could not have been worse. By the eighteenth century, Icelandic society was suffering possibly its worst years since the settlement. Famine and disease had taken a large percentage of the population, and economic, political, and cultural cohesion were as low as they would ever be. ${ }^{92}$ The causes and effects of this social climate were multiple, but it was within this cultural environment that some of the most significant Icelandic folk narratives come into being. It may not be surprising to discover that many of the tales that began to circulate during this time contribute to a uniquely formulated image of a distinctly Icelandic guardian figure-one who is local, familiar, intimate, and capable of combatting supernatural as well as natural threats. Folk narratives about Sæmundur fróði fill that gap on an imaginative, folkloric level if not in real life, as do other magician-priests found in the post-Reformation tales. ${ }^{93}$

\section{Final Thoughts: The Legacy of Sæmundur fródi and "The Stupid Boy and the Devil"}

We thus have an answer to the last of the three questions we started with: why does Sæmundur fróði appear in the tale "Tornæmi drengurinn og kölski"? The answer is that they are, in a way, the same story ... or, at least, they are stories of a similar type. Just as the ritual of Holy Communion saves the boy in "The Stupid Boy and the Devil," the complete, fully developed arc of Sæmundur's narratives articulate a similar saving ritual: A young man pursues knowledge that is forbidden, mysterious, or in some other way taboo. When the cost of this knowledge becomes too great, the young man must

90 Cormack, Saints in Iceland, 63.

91 Cormack, Saints in Iceland, 65-68.

92 See chapter 2 above, for a more complete discussion of these events. See also Karlsson's Iceland's 1100 Years, 142-48, for a brief overview.

93 Other magician-priests in the Icelandic folk record function similarly. Most notably Reverend Eiríkur of Vogsós (1638-1716), Hálfdán of Fell, and Snorri Bjornsson of Húsafell (d.1757), although the latter was a complicated figure (see Benedikts, "Introduction," 13), as well as other unnamed magicians who come to the aid of those in need, such as the magician who lays the deacon's ghost to rest in "Djákninn á Myrká." 
find a way to overcome the one who gave him his knowledge. These trials include temptation, fear, and the prospect of evil servitude to the Devil. Both Sæmundur and the stupid boy avoid that evil service (Sæmundur because he does not do black magic and the stupid boy because he escapes going into the service of the Devil in the first place). And both Sæmundur and the stupid boy are able to retain the forbidden knowledge they have acquired and, most importantly, they are able to use it after their ordeal is complete: Sæmundur serves his community and the stupid boy becomes a follower of Sæmundur for all the days of his life and becomes an ágætismaður (a great man).

There is something performative, even ritualistic about all this. In his description of the liminal phase in Shilluk rites of passage, Victor Turner writes: "The arcane knowledge or 'gnosis' obtained in the liminal period is felt to change the inmost nature of the neophyte, impressing him, as a seal impresses wax, with the characteristics of his new state. It is not a mere acquisition of knowledge, but a change in being." Oddi, Iceland is far from the Shilluk home of southern Sudan, yet the stupid boy and the young Sæmundur seem to experience a similar transformation. Unlike the rituals described by Turner, however, the Sæmundur stories must accommodate a Christian sense of culpability, moral judgment, and accountability for having acquired knowledge that is not just taboo but sinful. Post-medieval stories of Sæmundur's death address this unequivocally, and even though the story of "The Stupid Boy and the Devil" does not contain a deathbed scene for the stupid boy, it does describe something rather similar to Sæmundur's ordeal. Just as Sæmundur is first tempted on his deathbed to do evil acts and then terrorized by midges and demons, the stupid boy is likewise tempted to do evil and then terrorized at the end of his ordeal: first, his friends and family (even an image of Sæmundur) come to coax him away from the church, but when temptation does not work, the boy begins to see "alls konar ófreskjur og skrímsli og jafnvel djöflar" (all kinds of monsters ${ }^{95}$ and beasts and even devils). ${ }^{96}$ Both stories are also, in their own way, stories of redemption; both are the Christianized version of "happily ever after," in which not only is the protagonist saved from peril but he is also made better, smarter, wiser because of and through his peril; and further, not only is the protagonist redeemed, but the forbidden knowledge is somehow redeemed as well, so that our protagonist can use what he has learned to contribute something to his community. This redemption, of both personhood and knowledge, cuts to the heart of both stories: both Sæmundur and the stupid boy, in the end, remember who they are and where they come from.

94 Turner, "Betwixt and Between," 11.

95 Simpson translates this word, ófreskjur, as "supernatural visions" (Icelandic Magicians, 29). However, "monsters" is more appropriate because the term ófreskja refers to a physical creature who is clearly troublesome, not just supernatural but evil.

96 JÁ 1:484. 



\title{
CONCLUSION
}

\begin{abstract}
One may understand the cosmos, but never the ego; the self is more distant than any star. Thou shalt love the Lord thy God; but thou shalt not know thyself. We are all under the same mental calamity; we have all forgotten our names. We have all forgotten what we really are. All that we can call common sense and rationality and practicality and positivism only means that for certain dead levels of our life we forget that we have forgotten. All that we can call spirit and art and ecstasy only means that for one awful instant we remember that we forgot.
\end{abstract}

\section{G. K. Chesterton, Orthodoxy}

ONE OF THE great, if generally unspoken, tensions represented throughout this book is the anxiety between common sense, rationality, practicality, and positivism on the one hand, and spirit, art, and ecstasy on the other. Folklore, our modern sensibility tells us, is not rational and therefore not real, not verifiable, and not practical. But this is a false dichotomy predicated upon a misunderstanding of both folklore and rationality. Chesterton's reflection on this tension between the "dead levels of our life" and the "awful instant" in which we remember that humanity is on a common quest for its own identity may, if taken out of context, imply a certain kind of despair, yet Chesterton, for his part, sees it rather as the beginning of every fairy story. Every "forgotten name" in human history is also a precious opportunity for an exercise in remembering. This, Chesterton would assert, is the great adventure of every human life: to remember. Such adventures depend upon the act of storytelling, whether in literature, folklore, or even science. There is nothing unromantic about the pursuits of science, Chesterton would say. The scientific treatise has as much wonder and adventure in it as any of the "wonder tales" collected by Jacob and Wilhelm Grimm. The scientist may compose a different kind of narrative than the novelist, but both tell stories and thus both participate in the great adventure of humanity. All narratives-whether scientific, artistic, religious, political, social, romantic, or whatever else-contribute not only to the remembrances of a single individual identity but also to a broader cultural remembrance in which (or, at times, out of which) the individual must find their place. This cultural remembrancecalled "cultural memory" in the present study of Icelandic folklore-develops and changes over time according to the needs of the remembering community, and thus leaves an imprint upon the stories communicated throughout the long development of that culture.

For these reasons, Chesterton aims to illustrate in the above quotation that storytelling and cultural memory are now at a point of crisis. Science and logic can fail to achieve the status of romance for the same reasons that fairy tales and novels can fail: because the human mind can, at those "dead levels of our lives," cease to be awestruck by the parts of the world we do not understand. Only then do we "forget that we have forgotten" and our adventure fails. This type of second-order forgetfulnesswhich is so common in the modern world not because of our scientific mentality but because of our many and diverse distractions-leads to one of the most profound 
and destructive fallacies of the post-Enlightenment mindset: that the worlds of fairy, folklore, and elves (to say nothing of narrative more broadly conceived) must be illogical simply because they are unrealistic, and that they must be unscientific because they are un- (some may prefer to say "super-") natural. The present book answers this mistaken assumption about folklore by illustrating in five stories that folklore not only maintains an internal logical consistency but, further, that one of its primary functions as "story" is the establishing of a logic of belief. This assertion means more than just that an internal logic prevails in these stories; it means that these five stories provide conceptual and cultural mechanisms in which questions about the logic of beliefs are addressed by their tellers and hearers (whether in literate or oral modalities). In other words, participants who communicate and receive these stories go into their narrative experience with less of an understanding of the logic of belief than they have when they come out, and the process of participating in these stories helps participants formulate a way of understanding their own beliefs about the world around them. This is the cultural mechanism of folklore.

This mechanism may work in folklore upon any number of topics-medical, scientific, religious, sociological, or more. The five stories discussed here were chosen, in part, because they all indicate something about religious developments. These five stories represent the later stages of a long-developing cultural memory of belief that, when traced throughout its history, reveals the changing nature of religious belief in Iceland and beyond. The examination of the literary and folkloric history of "The Deacon of Myrká" illustrates how these developments occurred within a cultural memory of death, mourning, and the afterlife. As the religious climate in the North developed out of paganism and into Christianization and finally Lutheranization, views of the death and the afterlife changed as well. The development of these views in narratives from medieval vernacular texts and later, post-medieval folk narratives reflect not just the changes that took place in the respective religious systems but also an effort within the narratives to understand the changes, logically. The cultural memory imprinted upon these narratives seems unwilling - as Guðbrandur Porláksson would have wished- "to put away unprofitable songs"1 of the past and dispense with the "ancient images"2 of death and dying evident in the earliest Norse narratives. As is discussed in chapter 1 , the cultural memory at play in these narratives works to transform rather than to abandon, as is clear from the pejoration process evident in ATU 365 (The Dead Bridegroom Carries Off His Bride). We must recognize that this process is not a mechanism of Christian teaching but of folklore, narrative, and cultural memory. While the Christianization of the North might have provided the shift in religious belief that provoked such pejoration, the pejoration itself can only have occurred through narrative. The corresponding adjacency pair that sprang from the pejoration process in the history of ATU 365 may likewise

\footnotetext{
I Guðbrandur Porláksson, En nij Psalmabok, http://baekur.is/is/bok/000603210/0/23/Ein_ny_ Psalma_Bok__Bls_23.
}

2 Hastrup, “Iceland," 190. 
have had its moral and religious roots in Christianity, but the mechanism of developing an adjacency pair functions on a wholly folkloric and narrative level. These narratives become venues of belief in which cultural questions and anxieties about those beliefs are addressed to accommodate both the new, incoming religion (be it Christianity or Lutheranism) and the remembrances of the old religious and cultural world.

Gender, like death, represents a fundamental aspect of human existence. While different cultures may approach gender differently, all cultures must incorporate some understanding of gender into their views of their own past, present, and prospects for the future. This realization makes gender one of the most vital aspects of any study of cultural memory, particularly any study that proceeds diachronically or cross-culturally because it offers a common element of the human experience to examine. In other words, while different cultures will clearly approach gender in different ways, all cultures must approach it in some way. Thus, even apart from its obvious importance to the study of any culture, gender is one of the few human experiences and identities that truly allow for a rich and reliable cross-cultural or diachronic comparison.

The study of gender spheres in Old Norse and later Icelandic folktales-such as "Álfkonan hjá Ullarvötnum," “Gullbrá and Skeggi in Hvammur," and stories of female magic users in Iceland-suggests that gender and gender spheres were not passive during the long development of cultural memory throughout the North. Rather, they operated as functional contributors to their own transformation. Post-medieval narratives often rejected the expectation of a female gender sphere that was opposed to Christianity, as was evident in Old Norse sources. The Gullbrá narrative even created a tertiary sphere that took upon itself all of the evil and animosity toward Christianity that might have been perceived in the Old Norse female gender sphere. The Christian "male" sphere, as we might expect in Old Norse sources, is in this narrative occupied by the prominent (female) figure of the settlement period, Auður hin djúpuðga (the deep-minded), while the expected pagan "female" sphere is in the post-medieval narrative occupied by a wellknown pagan (male) of conversion narratives, Skeggi. It is the troll sphere, occupied by Gullbrá, that takes upon itself the identity of danger, of evil, and of heterodoxy. ${ }^{3}$ Other post-medieval female figures-such as Galdra-Manga (Manga the Sorceress), who turns the pains of childbirth upon an arrogant husband-assert the female sphere by their association with the home and by a certain heterodoxy, yet this heterodoxy does not possess the kind of evil we would expect from the troll sphere. Instead, the female sphere, once perceived as hostile to Christianity, has become in post-medieval tales a subject of conversion, as is evident in the story of the elf woman, Valbjörg. There, another new sphere, the elf sphere, takes shape. Like the troll sphere, the elf sphere represents a sphere of cultural identity that opposes Christianity. These narratives, for all this, sustain a cultural appropriation that can only be called misogynistic. The male, Skeggi, tracks down and kills the female troll, Gullbrá, and a group of males (representative of Christianity) capture and exorcise Valbjörg of her elf-hood. Nevertheless, these

3 Ármann Jakobsson, The Troll Inside You, 19. 
narratives participate in an arc of cultural memory that does not merely "deal with" gender spheres but works through the expectations of gender spheres in the North to make sense of the broader religious changes in the region.

In the study of attendant spirits, fylgjur, in chapter 3, a pejoration process once again occurs. This time, the pejoration takes the form of a peculiar demonization of the pagan attendant spirits of Old Norse sources. Though perhaps foreign to our modern minds, this type of supernatural attendance must have been of the most personal and intimate kind of belief. Norse fylgjur passed in families from generation to generation and in some instances were equated with the soul itself. Coming to terms with the loss of such an important element of pre-conversion belief must have been a deep and painful process. Here again the cultural memory of the region seems unable to abandon the remembrances of these pagan spirits entirely, opting instead to transform them into something terrifying (in the story Piðranda páttr ok Pórhalls) and, ultimately in the post-Reformation narratives, into something merely mischievous and destructive. Nevertheless, stories of these supernatural creatures preserve common functional characteristics with their pagan ancestors: inheritance, a soul-function, a (pejorated) assistance, and a propensity to exact punishments as they see fit.

In lieu of such pejoration, one must wonder whether fylgja stories possessed any obvious adjacency pair, such as is observed between "The Deacon of Myrká" and the story of the Reverend Porlákur, who dies on the same river as the deacon but who is kind and gentle in the afterlife. Here, the answer is ready-made, as Einar Ólafur Sveinsson points out: "Christianity brought to Iceland its own stock of stories to replace the myths and related stories it drove out: stories of angels, of the Blessed Virgin Mary, the apostles and other saints, of their miracles and glorious acts."4 These represent the Christian answer to attendant spirits. However, as this book attests, these Christian stories did not so much drive out those old "myths and related stories" as they did reckon with them. Nevertheless, an understandable anxiety crops up when considering the communication between the two examples of belief, perhaps namely because folk belief cannot be verified by any set doctrine or code (such as the Bible), yet as Tom Shippey notes concerning beliefs in ghosts, "people are perfectly capable of knowing several incompatible theories at once without feeling the need to decide on one or even to notice logical incompatibility." ${ }^{5}$ In broad terms, too, cultural memory can easily contradict itself, depending upon what version of a tale one hears, and Icelandic folk narratives are no exception to the rule. In folk narratives about fylgjur, for instance, the cultural memory represented there might best fit the description of "eclectic," but a warning should accompany this description. It is fair, and indeed necessary, to say that "eclectic" is the very nature of cultural memory, but in order for a folk tradition to be considered "living," it must possess this very quality, for only by transmission, shaping,

4 Einar Ólafur Sveinsson, Folk-Stories of Iceland, 74-75.

5 Tom Shippey, “Afterword: A Chair, A Sock, and Language," in The Shadow-Walkers: Jacob Grimm's Mythology of the Monstrous (Tempe: ACMRS, 2005), 382. 
and reshaping can folk beliefs come to be representative of the "folk." As Shippey states, "re-composition and experimentation are the mark of a living tradition, not ... the symptom of corruption." ${ }^{\prime}$ This recomposition of cultural memory may lead us to the conclusion that folk belief does not represent a codified religious doctrine, but the notion of a "code" of belief-a set of doctrines or beliefs that has been "codified," that is to say "written down" - came to Iceland and the rest of Scandinavia only with the introduction of Christianity. Pre-Christian belief itself functioned, it might be said, on the basis of eclecticism. No pagan "bible" or doctrine persisted throughout the pagan world; no universal church dictated what belief should look like. For this reason, too, the connection between folk belief and Christian religion becomes more readily visible in the study of the development of cultural memory in the North and especially in Iceland, where the function of folklore to "recompose," using Shippey's term, works not merely to replace old beliefs with new but rather to revise and remember them.

Cultural memories of sacred space display this function perhaps more than any other memories. On the level of religious belief, the changeover from paganism to Christianity and then to post-Reformation beliefs provided a gradual turn inward from the physical spaces of temples and churches to the heart and soul of each individual constituent, creating a new kind of sacred space that functioned on a more spiritual than physical level. This transformation provoked a deep cultural memory of contested sacred spaces in Iceland, which may be represented in four categories: contests between Christian and pagan spaces, contests in which pagan spaces have been defiled (and thus lost their sacredness), contests in which Christian sacred spaces have been defiled and must be cleansed, and finally contests between orthodox and heterodox Christian spaces. As the post-Reformation Lutheran ideas entered cultural memory, the great cosmic war between Heaven and Hell transformed these contested spaces into battlefields. The inward turn of sacred spaces, which focused more upon the internal soul than churches and sacred places, meant that the casualties of the cosmic war that raged upon these battlefields were the eternal souls of individuals, such as Galdra-Loftur Porsteinsson and Sveinn, the boy who wished to become an elf priest. One is lost and the other is saved, we may deduce from the narratives about them.

But the notion of sacred space in a Christian setting means more than just sacred and profane, Heaven and Hell, or the city of God and the city of the world.7 Transgression, as it is sometimes called, means going from sacred space into the profane, crossing the line that divides them. Post-Reformation Iceland again seems to have been reluctant to relinquish the diversity of landscapes that persisted in the long cultural memories of its past. Again, a transformation takes place, but in this case we do not observe a pejoration, as with the fylgjur and stories associated with ATU 365 (Dead Bridegroom), but rather a mediation, by which Sveinn, in the tale "Tungustapi," defies the typology of contests

\section{Shippey, "Afterword," 382-83.}

7 As is elaborated by Augustine of Hippo in The City of God. See De Civitate Dei = The City of God: Books XI \& XII, ed. and trans. P. G. Walsh (Oxford: Oxbow Books, 2015). See especially bk. 11, in which Augustine discusses the origins of both cities and the fall of the angels. 
of space in Icelandic cultural memory to bring some reconciliation to the memories of spaces outside Christendom, such as the elf church, and those inside Christendom, such as the Christian church at Tunga and the monastery at Helgafell. The cost of this type of mediation is great-Sveinn does not survive and thus becomes a tragic mediator-yet the rewards for his mediation are great as well. Though his journey costs him his life, the life of his brother, and eventually that of his father, Sveinn brings an uncommon beauty and wisdom into the world. His beautiful singing of mass and his wisdom that surpasses all others in Iceland indicate what can be gained by entering into the realm beyond Christendom and returning.

A similar function may be observed in the story of "The Stupid Boy and the Devil," in which a foolish, unintelligent boy unwittingly makes a deal with the Devil for the sake of becoming clever. The story has ancient roots in the history of Proto-Indo-European folklore and maintains over the centuries a multitude of iterations throughout the northern world, yet in the story of the "stupid boy" we also perceive a deeply local, deeply Icelandic experience. Like Sveinn, both the great Icelandic historical figure Sæmundur fróði and the stupid soy escape their desperate situation to bring a special skill or knowledge back to their community, yet some stories of Sæmundur at least (we hear nothing of the stupid boy's death) suggest that those forays into liminal spaces, forbidden knowledge, and heterodox beliefs bring about a beauty and knowledge that is not without a dear cost in the end. While Sveinn faces his death alongside his father upon again seeing the elf priest, Sæmundur (as is the case with other galdramenn, sorcerers) is assailed by demons upon his deathbed. Also like Sveinn, he seems to find salvation in the end. (Galdra-Loftur Porsteinsson was not so fortunate.) The function of the story of the stupid boy and that of the Sæmundur stories again suggests something of the cultural memory of the society that produced them. Again, Icelandic cultural memory was unwilling to ignore heterodox beliefs in forbidden knowledge and journeys into liminal places. Rather, that forbidden knowledge and journeys to the edges of orthodoxy became fundamental to the development of cultural memory of belief in the land-not, in this case, because these stories facilitate a transformation of cultural memory but rather because they became, and perhaps always had been, stories about the transformation of self.

Regarding this transformation of self, we may recall that one of the earliest iterations of the Sæmundur stories includes a deep and meaningful detail about his pursuit of forbidden knowledge: Sæmundur, it is said, has forgotten his name: Sæmundar páttr puts it, "hann týndi allri peiri er hann hafði á œskualdri numit ok jafnvel skírnarnafni sínu" (he had lost everything he had learned in his childhood, even his baptismal name). ${ }^{8}$ Sæmundur's adventure of remembering, of returning from the liminal space, and of using his forbidden knowledge (in some stories, it is his powerful magic and dominion over the Devil) serves as a prime example of a northern variation on the great adventure to which Chesterton alludes in the epigraph which opens this book. There can be no

8 Sæmundar páttr, 339. 
doubt that a real danger persists in Sæmundur's story, for there is no guarantee that he will ever remember his name-just as there is a real danger when the stupid boy treats with the Devil for the sake of gaining knowledge and wisdom, or when Sveinn wishes to become an elf priest, or when Galdra-Loftur strives (and fails) to wrench the magic book from the hands of Gottskálk grimmi, or when Valbjörg (or is her real name Vandráð?) struggles to resolve her own identity through the domination of (and ultimate submission to) Sigurður, or when the deacon (whose has forgotten that he was decent in life) desperately claws at the woman he loves, Guðrún (whose name carries within it the power of God-Guð), to join him in the afterlife. In one way or another-sometimes symbolically, sometimes directly-they have all forgotten their name. And when wereaders, listeners, the audience, or the storyteller-participate in their stories, we too internalize the experience of forgetting our own name; or, as G. K. Chesterton would say, "we remember that we forgot" ... and remembering is life's great adventure. 



\section{SELECT BIBLIOGRAPHY}

Almqvist, Bo. "Midwife to the Fairies (ML 5070) in Icelandic Tradition." In Legends and Landscape: Articles Based on Plenary Papers from the 5th Celtic-Nordic-Baltic Folklore Symposium, Reykjavík, 2005, edited by Terry Gunnell, 273-322. Reykjavík: University of Iceland Press, 2008.

al-Sīrāfi, Abū Zayd, and Aḥmad ibn Faḍlān, Two Arabic Travel Books: Accounts of China and India and Mission to the Volga. Edited and translated by Tim Mackintosh-Smith and James E. Montgomery, Library of Arabic Literature 17. New York: New York University Press, 2014.

Assmann, Jan. Cultural Memory and Early Civilization: Writing Rememberance, and Political Imagination. Cambridge: Cambridge University Press, 2011.

Ármann Jakobsson. The Troll Inside You: Paranormal Activity in the Medieval North. Earth, Milky Way: punctum, 2017.

— . "Vampires and Watchmen: Categorizing the Mediaeval Icelandic Undead." Journal of English and Germanic Philology 110 (2011): 281-300.

Bárðar saga. In Harðar saga; Bárðar saga; Porskfirðinga saga; Flóamanna saga: Pórarins páttr Nefjólfssonar; Porsteins páttr uxafóts; Egils páttr Síðu-Hallssonar; Orms páttr Stórólfssonar; porsteins páttr tjaldstœðings; Porsteins páttr forvitna; Bergbúa páttr; Kumlbúa páttr; Stjörnu-Odda Draumr, edited by Pórhallur Vilmundarson and Bjarni Vilhjálmsson, 99-172. Islenk Fornrit 13. Reykjavík: Hið Íslenzka Fornritafélag, 1991.

Benedikz, B. S. "Introduction." In Legends of Icelandic Magicians, edited by Jacqueline Simpson. Cambridge: Brewer, 1975.

Biskupa sögur 1. Edited by Peter Foote. Islenzk Fornrit 15.1-2. Reykjavík: Hið Íslenzka fornritafélag, 2003.

Biskupa sögur 2. Edited by Guðrún Ása Grímsdóttir. Islenzk Fornrit 16. Reykjavík: Hið Íslenzka fornritafélag, 2002.

Briggs, Katharine M. A Dictionary of British Folk-Tales in the English Language. 4 vols. Bloomington: Indiana University Press, 1970-71.

Bryan, Eric Shane. "Conversion and Convergence: The Role and Function of Women in Postmedieval Icelandic Folktales." Scandinavian Studies 83 (2011): 165-90.

. "Prospective Memory of Death and the Afterlife." Neophilologus 103 (2019): 543-60.

Byock, Jesse L. "Social Memory and the Sagas: The Case of Egils Saga." Scandinavian Studies 76 (2004): 299-316.

Christiansen, Reidar Thoralf. The Migratory Legends: A Proposed List of Types with a Systematic Catalogue of the Norwegian Variants. Helsinki: Suomalainen Tiedeakatemia, 1958.

Cleasby, Richard, and Gudbrand Vigfusson. Icelandic-English Dictionary. Oxford: Clarendon, 1874.

Clover, Carol. "Regardless of Sex: Men, Women, and Power in Early Northern Europe." Speculum 68 (1993): 363-87.

Cormack, Margaret. "Catholic Saints in Lutheran Legend: Post-Reformation Ecclesiastical Folklore in Iceland." Scripta Islandica 59 (2008): 47-71. 
The Saints in Iceland: Their Veneration from the Conversion to 1400. Bruxelles: Society of Bollandistes, 1994.

Cormack, Margaret J. "Saints and Sinners: Reflections on Death in Some Icelandic Sagas." Gripla 8 (1994): 187-218.

Cross, Tom Peete. Motif-Index of Irish Literature. Bloomington: Indiana University Press, 1952. Cunningham, Jack P. "Changing Fashions: The Coming of the Reformation to Iceland." Reformation 16 (2011): 65-92.

—. "Jón Arason, 'the Last Icelander' and the Coming of the Reformation to Iceland." Reformation and Renaissance Review 11 (2009): 245-73.

Driscoll, Matthew James. The Unwashed Children of Eve: The Production, Dissemination and Reception of Popular Literature in Post-Reformation Iceland. Enfield Lock: Hisarlik, 1996.

Duke, Siân. "Kristni Saga and Its Sources: Some Revaluations." Saga-Book 25 (2001): 346-66.

Eddukvæði. Edited by Jónas Kristjánsson and Vésteinn Ólason. Íslenzk Fornrit 2. Reykjavík: Hið Íslenzka Fornritafélag, 2014.

Einar Ólafur Sveinsson. The Folk-Stories of Iceland. Revised with preface by Einar G. Pétursson, translated by Benedikt Benedikz, and edited by Anthony Faulkes. Viking Society for Northern Research, Text Series 16. London: Viking Society for Northern Research, University College London, 2003.

Ellis, Hilda Roderick. The Road to Hel: A Study of the Conception of the Dead in Old Norse Literature. New York: Greenwood, 1968.

Erlendur Haraldsson. "Psychic Experiences a Third of a Century Apart: Two Representative Surveys in Iceland with an International Comparison." Journal of the Society for Psychical Research 75 (2011): 76-90.

Eyrbyggja saga: Brands páttr Qrva, Eiríks saga Raud́a Groenlendinga saga, Groenlendinga páttr. Edited by Einar Ólafur Sveinsson and Matthías pórðarson. Íslenzk Fornrit 4. Reykjavík: Hið Íslenska Fornritafélag, 1935.

Fentress, James, and Chris Wickham. Social Memory: New Perspectives on the Past. Oxford: Blackwell, 1992.

Gísla saga Súrssonar. In Vestfirðinga sögur. Edited by Björn Pórólfsson and Guðni Jónsson, 1-118. Íslenzk Fornrit 6. Reykjavík: Hið Íslenzka Fornritafélag, 1943.

Gísli Sigurðsson. The Medieval Icelandic Saga and Oral Tradition: A Discourse on Method. Cambridge, MA: Harvard University Press, 2004.

Green, Richard Firth. Elf Queens and Holy Friars: Fairy Beliefs and the Medieval Church. Philadelphia: University of Pennsylvania Press, 2017.

Grønlie, Siân. "The Book of the Icelanders." In Íslendingabók, Kristni saga = The Book of the Icelanders, The Story of Conversion, translated by Siân Grønlie, 3-14. London: Viking Society for Northern Research, 2006.

_. " 'Neither Male nor Female'? Redeeming Women in the Icelandic Conversion Narratives." Medium Avum 75 (2006): 293-318.

Guðbrandur Porláksson. En Ny Psalma Bok. Hólar, Iceland: 1589. http://baekur.is/is/bok/ 000603210/0/23/Ein_ny_Psalma_Bok_

—. Vísnabók Guðbrands. Edited by Jón Torfason. Reykjavík: Bókmenntafræðistofnun Háskóla Íslands, 2000.

Gunnar Karlsson. Iceland's 1100 Years: The History of a Marginal Society. London: Hurst, 2000. Gunnell, Terry. “Ansgar's Conversion of Iceland.” Scripta Islandica 60 (2009): 105-18. 
. "Clerics as Collectors of Folklore in Nineteenth-Century Iceland." ARV: Nordic Yearbook of Folklore 68 (2012): 45-66.

—. "Daisies Rise to Become Oaks. The Politics of Early Folktale Collection in Northern Europe." Folklore 121 (2010): 23-24.

. "Hof, Halls, Goðar and Dwarves: An Examination of the Ritual Space in Pagan Icelandic Hall." Cosmos 17 (2001): 3-36.

—. "Narratives, Space, and Drama: Essential Spatial Aspects Involved in the Performance and Reception of Oral Narrative." Folklore (Tartu) 33 (2006): 7-26.

—_. "The Return of Sæmundur: Origins and Analogues." In Pjóðlifog Pjóðtrú: Ritgerðir Helgaðar Jóni Hnefli Aðalsteinssyni, edited by Jón Jónsson et al., 87-111. Reykjavík: Pjóðsaga, 1998.

_. "Waking the Dead: Folk Legends Concerning Magicians and Walking Corpses in Iceland." In News from Other Worlds: Studies in Nordic Folklore, Mythology and Culture, edited by Merrill Kaplan and Timothy R. Tangherlini, 235-66. Berkeley: North Pinehurst, 2012.

Halbwachs, Maurice. Les Cadres sociaux de la mémoire. Paris: Alcan, 1925.

Hallgrímur Pétursson, Hallgrímskver: Sálmar ok kvæði. Reykjavík: Leiftur, 1952.

Handbook of Pre-Modern Nordic Memory Studies: Interdisciplinary Approaches. Edited by Jürg Glauser, Pernille Hermann, and Stephen A. Mitchell. 2 vols. Berlin: de Gruyter, 2018.

Hastrup, Kirsten. “Iceland: Sorcerers and Paganism." In Early Modern European Witchcraft, edited by Bengt Ankarloo and Gustav Henningsen, 383-401. Oxford: Clarendon, 1996.

—. Nature and Policy in Iceland 1400-1800. Oxford: Clarendon, 1990.

Hermann, Pernille, and Stephen A. Mitchell, eds. "Memory and Remembering: Past Awareness in the Medieval North." Special issue, Scandinavian Studies 85, no. 3 (2013).

Hughes, Shaun F. D. "The Re-emergence of Women's Voices in Icelandic Literature, 1500-1800." In Cold Counsel: Women in Old Norse Literature and Mythology, edited by Sarah M. Anderson and Karen Swenson, 93-128. New York: Routledge, 2002.

—_. "Report on Rímur." Journal of English and Germanic Philology 79 (1980): 477-98.

Íslendingabók. Landnámabók. Edited by Jakob Benediktsson. Íslenzk Fornrit 1. Reykjavík: Hið Íslenzka Fornritafélag, 1986.

Jochens, Jenny. "Late and Peaceful: Iceland's Conversion Through Arbitration in 1000." Speculum 74 (1999): 621-55.

—. Old Norse Images of Women. Philadelphia: University of Pennsylvania Press, 1986.

Jón Árnason. Íslenzkar pjóðsögur og ævintýri. Ed. Árni Böðvarsson and Bjarni Vilhjálmsson. 6 vols. New edition. Reykjavík: Pjóðsaga, 1954-61.

Jón Espólín, Íslands Árbækur í sögu-formi, vol. 9. Copenhagen: Hið Islendska Bókmentafélag, 1830.

Jón Hnefill Aðalsteinsson. A Piece ofHorse Liver: Myth, Ritual and Folklorein Old Icelandic Sources. Translated by Terry Gunnell and Joan Turville-Petre. Reykjavík: Háskólaútgáfan, 1998.

—_. "Sæmundr fróði: A Medieval Master of Magic." Arv 50 (1994): 117-32.

__. "Six Icelandic Magicians after the Time of Sæmundur Fróði." Translated by Terry Gunnell. Arv 52 (1996): 49-61.

—. Under the Cloak: A Pagan Ritual Turning Point in the Conversion of Iceland. 2nd ed. Reykjavík: Háskólaútgáfan, 1999.

Jón Porkelsson Vídalín. Vídalínspostilla: Hússpostilla eður Einfaldar predikanir yfir öll Hátíða og Sunnudagaguðspjöll árið um Kring. Edited by Gunnar Kristjánsson and Mörður Árnason. Reykjavík: Mál og Menning, 1995. 
Karras, Ruth Manzo. "God and Man in Medieval Scandinavia: Writing-and Genderingthe Conversion." In Varieties of Religious Conversion in the Middle Ages, edited by James Muldoon, 100-114. Gainesville: University Press of Florida, 1997.

Keyser, Rudolph, P. A. Munch, Gustav Storm, and Ebbe Hertzberg. Norges gamle love indtil 1387, vol. 1. Christiania: Gröndahl, 1846.

Kress, Helga. “'Óparfar unnustur áttu’: Um samband fjölkynngi, kvennafars og karlmennsku í Íslendingasögum.” In Galdramenn, edited by Torfi H. Tulinius, 21-49. Reykjavík: Hugvísindastofnun Háskóla Íslands, 2008.

Kvideland, Reimund, and Henning K. Sehmsdorf. Scandinavian Folk Belief and Legend. The Nordic Series 15. Minneapolis: University of Minnesota Press, 1988.

Le Roy Ladurie, Emmanuel. Montaillou: The Promised Land of Error. New York: Braziller, 1978. Lethbridge, Emily. "Gísla saga Súrssonar: Textual Variation, Editorial Constructions and Critical Interpretations." In Creating the Medieval Saga: Versions, Variability and Editorial Interpretations of Old Norse Saga Literature, edited by Judy Quinn and Emily Lethbridge, 123-52. Odense: University Press of Southern Denmark, 2010.

Loftur Guttormsson. Frá Siðaskiptum til Upplýsingar. Edited by Hjalti Hugason. Reykjavík: Alpingi, 2000.

Magnús Fjalldal. The Long Arm of Coincidence: The Frustrated Connection between Beowulf and Grettis Saga. Toronto: University of Toronto Press, 1998.

Margrét Eggertsdóttir. "From Reformation to Enlightenment." In A History of Icelandic Literature, edited by Daisy Neijmann, 174-250. Histories of Scandinavian Literature 5. Lincoln: University of Nebraska Press, 2006.

McKennell, John. Meeting the Other in Norse Myth and Legend. Cambridge: Brewer, 2005.

Minni and Muninn: Memory in Medieval Nordic Culture. Edited by Hermann, Pernille, Stephen A. Mitchell, and Agnes S. Arnórsdóttir. Turnhout: Brepols, 2014.

Mitchell, Stephen A. Witchcraft and Magic in the Nordic Middle Ages. Philadelphia: University of Pennsylvania Press, 2011.

Mundal, Else. Fylgjemotiva i Norrøn Litteratur. Oslo: Universitetsforlaget, 1974.

Möller, Arne. Vídalínspostilla. Copenhagen: Gyldendalske Boghandel, 1922.

Nedkvitne, Arnved. Lay Belief in Norse Society, 1000-1350. Copenhagen: Museum Tusculanum Press, University of Copenhagen, 2009.

Nora, Pierre. Rethinking France: Les Lieux de mémoire. 4 vols. Chicago: University of Chicago, 1999-2010.

Orri Vésteinsson. The Christianization of Iceland. Oxford: Oxford University Press, 2000.

Sæmundar páttr. In Biskupa sögur 1, edited by Peter Foote, 337-43. Islenzk Fornrit 15.2. Reykjavík: Hið Íslenzka fornritafélag, 2003.

Sagnagrunnar. http://sagnagrunnur.com.

Sawyer, Birgit. Kvinnor och Familj i det forn- och medeltida Skandinavien. Occasional Papers on Medieval Topics 6. Skara: Victoria bokfölag, 1992.

- "Women and the Conversion of Scandinavia." In Frauen in Spätantike und frühmittenlalter: Lebensbedingungen, Lebensnormen, Lebensformen, edited by Werner Affeldt and Ursula Vorwerk, 263-81. Sigmaringen: Jan Thorbecke, 1990.

Saxo Grammaticus. The Histories of the Danes, Books I-IX. Edited by Hilda Ellis Davidson, translated by Peter Fisher. Cambridge: Brewer, 1979.

Simpson, Jacqueline, trans. Icelandic Folktales \& Legends. Stroud: Tempus, 2004. 
— for the Folklore Society, 1975.

_. "Witches and Witchbusters." Folklore 107 (1996): 5-18.

Stitt, J. Michael. Beowulf and the Bear's Son: Epic, Saga and Fairytale in Northern Germanic Tradition. New York: Garland, 1992.

Strömbäck, Dag. "The Concept of the Soul in Nordic Tradition.” Arv: Tidskrift för Nordisk Folkminnesforskning 31 (1975): 5-22.

Sturlunga saga.Edited by Örnólfur Thorsson and Bergljót Kristjánsdóttir. 3 vols. Reykjavik: Mál og menning, 2010.

Sverrir Jakobsson. "Conversion and Cultural Memory in Medieval Iceland." Church History 88 (2019): 1-26.

_. "Heaven Is a Place on Earth: Church and Sacred Space in Thirteenth Century Iceland." Scandinavian Studies 82 (2010): 1-20.

Thompson, Stith. Motif-index of Folk-Literature: A Classification of Narrative Elements in Folktales, Ballads, Myths, Fables, Mediaeval Romances, Exempla, Fabliaux, Jest-Books, and Local Legends. Revised edition. 6 vols. Bloomington: Indiana University Press, 1955-58.

Thordarson, Sigurdur Arni. Limits and Life: Meaning and Metaphors in the Religious Language of Iceland. New York: Lang, 2012.

Uther, Hans-Jörg. The Types of International Folktales: A Classification and Bibliography, Based on the System of Antti Aarne and Stith Thompson. 3 vols. Helsinki: Suomalainen Tiedeakatemia, Academia Scientiarum Fennica, 2004.

Van Engen, John. "The Christian Middle Ages as an Historiographical Problem." American Historical Review 91 (1986): 519-52.

Vilborg Auður Ísleifsdóttir. Siðbreytingin á Íslandi 1537-1565: Byltingin að ofan. Reykjavík: Íslenska bókmenntafélag, 1997.

Vitz, Evelyn Birge. "From the Oral to the Written in Medieval and Renaissance Saints' Lives." In Images of Sainthood in Medieval Europe, ed. Renate Blumenfel-Kosinski and Timea Klara Szell, 97-114. Ithaca: Cornell University Press, 1991.

Wanner, Kevin J. "Purity and Danger in Earliest Iceland: Excrement, Blood, Sacred Space, and Society in Eyrbyggja Saga." Viking and Medieval Scandinavia 5 (2009): 213-50.

William of Malmesbury. Gesta regum Anglorum. Edited and translated by R. A. B. Mynors, R. M. Thomson, and M. Winterbottom. 2 vols. Oxford: Clarendon, 1998-99. 



\section{INDEX}

accountability, 131-33, 139

Adam and Eve, 119

adjacency pairs, 35, 38-39, 41, 43-44, $62,142-44$

aðsókn, 77, 81-83, 85-86, 88

Æsir, 107

afterlife

in folktales, 43-44

journey to, 28-36, 38

prospects in, 105, 133-35

views on, 113, 142, 144, 147

afturganga, 41

álag, 51, 86-87, 103

álagablettir, 52, 103

Aldis (king), 85

"Álfkonan hjá Ullarvötnum" (The Elf-

woman by Wool Lakes), 19, 45-47, 51, 60-66, 143-45

álfrek ganga (driving away the elves), 97,100

Álftanes, 20, 67-69

altar, 89-90, 92, 95-96, 120

Alping, 13, 14, 31, 68

alpyða (folk), 15, 16, 19

Angel of Death, 28

angels, 15, 76, 112, 144

"Anna á Bessastöðum” (Anna at

Bessastaðir), 81-82

"Árbæjar-Skotta eða Nýjabæjar-Skotta” (The

Skotta of Árbæjar or of Nýjabæjar), 79

Árbækur, Jón Espólín, 104

Ari Porgilsson's (1068-1148), 5-6, 14, 93

Ark of the Covenant, 97-98

Árni Magnússon, 51, 57, 128

Ásólfur (settler), 94

attendant spirits see fylgja/-ur

audience, 6, 10, 41, 43, 49, 96, 113, 124, 133,147

Auður Ketilsdóttir, 39, 41, 43, 51-54, 65, 94-96, 127, 143

Augustine of Hippo, 109, 145
Bægisá, 23-24

baptism, 42, 61, 95, 111, 122, 134

baptismal name, 126, 127, 146

Bárðar saga Snæfellsáss, 41-42, 88, 121-23

Bárður Snæfellsáss, 42, 88

Bear's Son Tales, 38-43

Benedikt Björnsson (parson), 68-69

Beowulf, 40-42

Bessastaðir, 68, 81

Bible (Christian), 32-33, 106, 112, 144-45;

see also Guðbrandur Porláksson

Bjarni Gunnlaugsson (headmaster), 68

Bjarni Halldórsson, 68

Björn Porleifsson (bishop, informant), 57, 128

blasphemy, 106-8, 115

blessings, 45, 74, 100, 110, 137

Brennu-Njáls saga, 48, 77

Brynhildur Buðladóttir, 27-28, 36

burial, 29, 30, 61, 95, 134

burial mound, 25, 27, 42, 122-23

Catholicism, 12-16, 31-32, 64, 100-102, 111,138

Chesterton, G. K., 141, 146, 147

Child, Francis, Ballads, 25, 31, 36, 44

childbirth, 58-60, 64, 74, 143

Christ, 93, 112-13, 37, 98, 109-10

Christenret (Jon of Nidaros) 99-100

Christian III (king), 15

Christianization, 1-2, 7-8, 11-12, 31, 34, 48, $50,56,73,77,88,142$

Christmas/Christmas Eve, 23, 45

church(es)

bells, 24, 40, 109, 117

building, 41, 43, 52, 53

moving, 91, 94, 97, 113

services/festivals, 33, 108, 125, 130

site/structure of, 96, 98-100, 111-15,

117-18, 120-23, 127

yard, 24, 61, 99, 107, 12, 134

see also elf church 
communion of saints, 98,138

conversion, 7-8, 11-12, 15-16, 39, 42-43, 47-48, 51-52, 60-65; see also

Christianization

Cornish folklore, 30

cosmic war, 108-10, 114, 120, 123, 134, 145

cremation, 29

cross (Christian), 39-40, 94, 98, 110

Crymogæa (Arngrímur Jónsson), 54

cultural compromise formation, 21, 62

cultural memory

of belief/religion, 43-44, 98, 116

contrasted with social memory, 4

definitions of, ix, 1-12, 141-46

of fylgjur, 70-72, 87

of gender (spheres), 50, 51-54, 64-66

Icelandic, 15-17, 21, 46-47, 110, 121

internal/external contexts for, 4, 6, 11, $19-20,43,65$

of Loftur Porsteinsson, 104-5

malleability of, 6, 10-11, 87

modalities of, 4, 6-7, 9-11

prospective cultural memory, 113

of sacred/profane space, 90-96,

101, 114-15

of Sæmundur Sigfússon, 124

within narratives, 25, 35, 118

Daði Guðmundsson, 14-15, 100

"Dalakúturinn" (The Treasure Cask), 81

"Dapur er dauðinn kaldi" (Dreary is Cold

Death), 36

"Dauði Hálfdanar prests" (The Death of Reverend Hálfdan), 133

death and mourning, 1, 20, 23-25, 27-31,

34-38, 43-44, 53, 58, 75, 90-91, 95,

108, 113, 131-36, 142-43; see also

prospective cultural memory of

deathbed scenes, 40-41, 132-34, 139, 146

De Gestis Regum Anglorum (William of

Malmesbury), 125, 131-32

Denmark, 12-15, 32, 100-101

Devil, 15, 55, 78, 103, 105-7, 109-10, 113, $115,117-27,129-32,136,139,146-47$ dís/-ir, 73-75, 77, 85 discursive tales, 35

“Djákninn á Myrká," 19-20, 23-25, 27, 29,

$31,34-35,38,43-44,78,142,144,147$

door(way)s, 40, 45, 89-90, 110, 114, 130

draugur/-ar

ættardraugur (family ghost), 70, 77, 83

bæjardraugur (farm ghosts), 77, 79

fylgidraugur (attendant ghost), 69-70

ghost(s), 70

dreams, 36-37, 42, 45, 49, 75, 81, 117

dream-woman, 48-49, 133, 136

dritsker (shit skerry), 97

“Dvergasteinn" (Dwarf Stone), 91, 94

Easter, 90-91

ecclesial belief/doctrine, 3, 12, 48, 101-2; see also orthodoxy

Eddic poetry, 1, 25-28, 30, 34

Eggert Bjarnason (reverend), 69, 80

Einar Ólafur Sveinsson, 8, 18-19, 71-73, 77-78, 104, 133-34, 144

einherjar, 26

Eiríkur of Vogsós (reverend, galdramaður), 45-46, 61, 64, 108, 127, 129n53, 130n55, 133-34, 138n93

"Eiríkur Prestur Grafinn" (The Reverend Eiríkur Buried), 133-34

elf/elves

álfkonan (elf woman), 45-47, 51, 60-66

-bishop/priest, 89-90, 97, 103n52

-church, 21, 89-92, 113-16

-priesthood, 89

-ride, $89-90$

-sphere, 64

Elliðá river, 67

Enlightenment, 18, 142

Eucharist/Communion, 98, 103, $117-20,138$

evil, 24-25, 34-35, 39, 42-43, 70, 143

different from paganism, 52-54, 63

punishment of, 78

magic and, 102, 119-23, 134, 136

rituals/acts, $60,113-14,139$

turning to, 105-8

Eyjafjörður, 37-38 
Eyjólfur Jónsson, 69, 80

Eyrbyggja saga, 91-92, 95-97, 99, 113-15

fairy/fairy dwelling, 46, 61, 141-42

farmstead, 15, 33, 80, 111

fate, $38,74-76,110$

feminization, 50, 55-56

fetch (as fylgjur or attendant spirit), 75, 81-86

"Fjósamaðurinn í Odda" (The Cowherd at Oddi), 130

Flateyjarbók, 8

flugumýrarskotta, 72

folk motifs

E501 (The Furious Host), 91

E756.3 (Black and white birds fight over a man's soul), 134

F302 (Fairy Mistress), 61

F302.1 (Man goes to fairyland and marries fairy), 61

F382 (Exorcizing Fairies), 61

F941.2 (Church Sinks Underground), 120,122

G243 (Witch's Sabbath), 121

G243.2 (Parody of church ceremony at witch's Sabbath), 121

G303.9.1.1 (The Devil builds a bridge), 129

M211 (Man sells soul to devil), 118

M216.1 (The Devil helping a man study for the priesthood in exchange for his soul), 118-19, 123

V331.8 (Fairy Converts to Christianity), 61

forbidden knowledge, 105-6, 111, 127, 138-39, 146

fornaldarsögur, 34, 75-76, 85

Frostaping, 99

fylgja/-ur, 20, 67-88, 109, 121, 133-34, 144-45

ættarfylgja, 68-70, 79, 87

fylgjuengill, $75 \mathrm{n} 26$

fylgjukona, 74-76, 82

as a good spirit 53

inheritance of, $68,71,78-80,144$ mannafylgjur, 77, 79

other variants (fylgð, fylginn, fylgisamur, kynfylgja) 74

galdramaður (magician), 31, 37, 54, 105, 118, 120-21, 124, 133-34; see also Sæmundur fródi Sigfússon, Eiríkur of Vogsós, Galdra-Loftur, and witchcraft Galdrakerlingar, 54, 59-60

Galdranornir, 54

"Galtardalstófa” (“Galtardal's Fox"), 81-84

Gárun (short for Guðrún), 24, 35

gender, 1, 19, 45, 62-64, 66

gender spheres, 45-48, 50-54, 58-60, 62-65, 143-44; see also troll-sphere, elf-sphere

Gerbert of Aurillac (Pope Sylvester II), 125, 131-33

Gestur Bárðsson, 42, 88, 121-23

Gísla saga Súrssonar, 133, 136

Gísli Vigfússon, 72

Gissur Einarsson, 13-14

God/Guð

Christian/Judeo-Christian, 15-16, 53, $120,123-24,138,141$

commandments of, 97-98

folktales about, 62n70, 78

indwelling of, 111-12

kingdom of, 145

the name of, 45-46, 61, 147

the trinity, 49

vs. pagan gods, $41-43$

goddess, 73,75

gods, pagan, 41-43, 75, 88

Göngu-Hrólfs saga, 75

Gottskálk grimmi (the cruel) Nikulásson

(bishop), 105-6, 109, 121, 147

Gráskinna, 105

grave/graveyard/ 24, 9, 24-25, 30-31, 105-9, 122, 127

grief/grieving, 26-30, 36, 86

Grimm, Jakob, 17, 73n21, 141, 144

Grímsnes, 69

guardianship (angel/spirit), 75, 82, 129n53, 136, 138 
Guðbrandur Porláksson (bishop)

Ein ný sálmabók (A New Book of Hymns), 15-16, 64, 142

Guðbrandsbiblía (Guðbrandur's Bible), 32

Lutheran leader, 15-16, 18, 32, 34, 37, 54, 65,142

Vísnabók Guðbrands (Guðbrandur's Book of Verse), 16, 47n7

Guðmundur Arason (bishop), 135

Guðrún (containing the name of God), 35,147

Guðrún Gjúkadóttir, 48-50

Guðrún of Sel (m. Jón of Sel, diplomat), 67-68, 70, 80, 86

Gullbrá, 39-43, 50-54, 60, 62-65

“Gullbrá og Skeggi í Hvammi” (Goldbrow and Skeggi in Hvammur), 39-40, 42-43, 50-54, 63-65, 143

Halldór Porbergsson (informant), 57

Halldór Bjarnason, 68

Hallfreðar saga, 75-76, 78

Hallfreður Óttarsson, 75-76

Hallgrímur Pétursson, 37, 44

hamaskipti, 77

hamingja/-jur, 73-73, 76-77

"Handbókin" (The Handbook), 130n55

Harðar saga og Hólmverja, 42

Heaven, 31, 35, 36, 44, 109, 112; see also lifandi manna landi

Helgafell, 14, 63, 90-91, 95-97, 101-2

"Helgafellsklaustur" (The Cloister at

Helgafell), 102

"Helgakviða Hundingsbana Önnur" (The

Second Lay of Helgi Hunding's Bane), $25,27,30-31$

Helgi Hundingsbani, 25-27

Hell, 31, 34, 44, 109, 132, 145

Hellisheiði, 69

"Hestastuldurinn" (The Horse

Theft), 130n55

heterodoxy

opposition to orthodoxy, ix, 2-4, 143

reconciliation with orthodoxy, 62, 64

relating to paganism, 44, 47, 96, 113 responses to, 91, 113-19;

within narratives, 34, 145-46

see also orthodoxy, lay belief

Hildishaug, 103

Historia de Antiquitate Regum

Norwagiensium (An Account of the

Ancient History of the Norwegian

Kings), 9

historical anthropology, 3n4

"Hítardals-Skotta," (Skotta of

Hítardalur), 85

Hítardalur, 68, 85

"Hleiðrargarðs-Skotta” (The Skotta of Hleiðrargarður), 79

hof (pagan temple), 95-97

Hofsstaðir, 95, 97

Hólar, 12-15, 32, 57, 100, 103, $105,112,125$

Hólmfríður Porvaldsdóttir (informant), 20n80, 67n2

Holy Cross Day, 117-18

holy water, aspersion, 99, 122

"Hörgslands-Móri" (Móri of

Hörgsland), 85-86

horse(s), 23-24, 38-39, 49, 76, 84-86, 90

Hörður Grímkelsson, 42

Hörgárdalur, 23, 37-38

Hugr (soul), 81

Huitfeldt, Christoffer, 13

huldufólk (hidden people), 38, 52n32, 60-61

Hvammur, 39-41, 51-53

"Hvítárvalla-Skotta" (The Skotta of Hvítárvellir), 78

ibn Faḍlān, Aḥmad, 38-40

indwelling of God, 111-12, 115

internal struggle, 111, 113, 125-27, 132

Ingibjörg Jónsdóttir, 69, 83

inward turn, 111-13

"Irafells-Móri" (Móri of Irafell), 83-84

Irish folklore, 93

Irish monks in Iceland, 61

Islandiæ Nova Descriptio (Peder Hansen

Resen), 72

Íslendinga saga, 48-49, 135 
Íslendingabók, 4-5, 93, 95, 101, 124

Íslendingasögur (Icelandic family sagas), 34; see also names of specific sagas

Jón Arason (bishop), 12-14, 100, 106

Jón Árnason, 1, 17-20, 24, 57-60, 64, 71, 73, $77-78,81,88,91,104,108,124,128$

Jón Jónsson (teacher), 68

Jón of Sel (diplomat), 67-68, 70, 80, 86

Jón Ögmundsson (bishop), 125-28

Jón Steingrímsson, 72

Jón Pórðarson, 85

Jón Porkelsson Vídalín (bishop), 32-34, 37, 110, 112-13

Vídalínspostilla, 33-34, 44, 112-13

Jón Porleifsson (reverend, informant), 20n78, 39n49, 51n30, 89n1, 91n5

Jóns saga Helga, 124-28, 130-32

Jóreiður Hermundardóttir, 49

Jórunn Halldórsdóttir, 69, 80

Ketill fiflski (the foolish), 103

Ketill Porsteinsson (bishop), 4-5

King Óláfur Haraldsson, 42

Kirkjubær, 101-3

Kópavogur, 68

Kort Kortsson, 83-84

Kristni saga, 39, 48, 53, 63

“Kölski mokar Oddafjósið” (Kölski Mucks out the Cowshed at Oddi), 130

"Kölski smíðar brú á Rangá” (The Devil Builds a Bridge over the Rangá River), 129

kvöldvaka (night-wake), 17, 33-34, $44,46-47$

Landnámabók (Book of the Settlements), 92-96, 101

landshjálp (land relief), 13

landvættir, 65, 93-94

ast rites, 133-35

lay belief, 2-3, 37, 134-35, 145

lifandi manna landi (to the land of the living), 36

liminal stage, 126-27, 139, 146 literacy, 2, 8-11, 42, 56, 88, 137, 142; see also orality

"Ljósmóðurstörf Höllu” ("Halla as Midwife"), 58

Loftur Porsteinsson (Galdra-Loftur), 102-11, 114-15, 120-23, 145-47

logic of belief, 21, 94, 142

Lord's Prayer, 106-7, 115, 121

Luther, Martin, 110

Lutheranism, 31-34, 108-11, 136,143

Lutheranization, 11, 15-17, 32-22, 142

magic

attitudes towards, 134, 136, 138-39

black/malefic, 106-8, 122, 133, 139

objects, 40-42

Sámi, 71

seduction, magical, 59

study/acquisition of, 102-8, 121-22, 124, $127 \mathrm{n} 40,146-47$

of witchcraft, 53-60

see also Black School

magician see galdramaður

Magnús Arason (informant), 57

Magnús Grímsson, 17

Magnús Ólafsson, 68

Malleus Maleficarum (The Hammer of

Witches), 55, 121

Margrét Pórðardóttir (Galdra-Manga),

59-60, 143

Markús Gíslason (informant, priest), 20n81, $117 \mathrm{n} 1,118 \mathrm{n} 2$

Marteinn Einarsson, 14-15

Mary Magdalene, 49

mechanisms of belief, 21, 44, 62, 97, 101, 142-43

midwife, 58-59

Mímir, 107

ministration/ministry, 128-31, 133

"Móhúsa-Skotta" ("Skotta of Móhús"), 84 móri/-ar, 77n42, 83-87; see also individual folktales about

Moses, 97 
Moving Day, 118; see also Holy Cross Day Myrká, 19-20, 23-25; see also “Djákninn á Myrká"

narrative doorways, 20-21 necromancy, 107-8

New Church Ordinance, 13

New Year's Eve, 89, 114-15

norn/-ir, 56-57, 77n36

"Nornin á Saxlandi" (The Witch of Germany), 57

Oddi, 126-30, 132, 139

Oddur Árnason (priest), 86

Óðinn, 26, 107

ófreskisgáfur (second sight), 37-38, 75, 81-83

Ögmundur Pálsson (bishop), 13

Óláfs saga Tryggvasonar, 94

Ólafur Sveinsson of Purkey (informant/ collector), 19n77, 45n1

Óláfur Tryggvasson, 12

ondvegissúlurnar (high seat pillars), 92, 95-96

Ong, Walter, 8

orality

oral culture/tradition, ix, 11, 30, 34, 42, 52, 64n80, 65-66, 113, 128, 137

oral transmission, $6,8-9,10,17,40 \mathrm{n} 52$, $47,78,104-5,133,137,142$

re-oralization, 33

see also literacy

Ormur Sturluson, lawman, 15

orthodoxy, ix, 2, 18, 21, 44, 50, 62, 64-66, 96, 113-15, 137, 145-46; see also heterodox

other-/under-world journey, 28-31, 36, 38, $46,78,91,116$

Öxará, 68

parfait (Albigensian priest), 81

Peder Hansen Resen: Islandiæ Nova

Descriptio, 72

pejoration

of assistance, $73-78$ of ATU 365, 29-35, 38

of elf stories, 62

process of, 29, 43-44, 142, 144-45

Pentateuch, 97

Pentecost, 112

performance, $6,9,19 \mathrm{n} 75,114,133,139$

periphery, 50n23, 62-66

post-medieval era, 1-2, 4, 8-12, 19-21, 29-34, 42-44

pre-Christian belief in ATU 365, 29-30, 37

folk-representatives of, 62-65

in Iceland, 39-44, 48-54, 92-101, 108, 109-10

post-conversion remnants of, 2, 7-8, 56

post-medieval remnants of, 20,34 , $70,72-75,77,83-88,113-15$, $122,142-45$

(Proto-)Indo-European, 21, 24, 29n12, 34, $43,70,91,118-19,146$

profaned space, 102, 106, 108, 109, 114-15

Psalms, 101-2, 106

"Púkinn og fjósamaðurinn" ("The Demon and the Cowherd), 129-30

pyre, 27-29; see also burial

Ragnheiður Bjarnadóttir, 68-69, 79

Raknar (evil king), 42, 121-23

Rauðskinna, 105, 109

redemption, 43, 64, 99, 106, 108-9, 117, 133,139

Reformation 1-3, 38, 56, 58, 100-103, 109-10

Icelandic history of, 11-15, 31-34

in folktales, 64-66

theology/doctrine, 15-17, 32-34, 44, 110-13, 138

see also Lutheranism, Lutheranization, post-medieval era

reginnaglar (sacred nails), 96

Reykjavík, 67-68

ríma/-ur, 16-17, 32-33, 61

rites of passage, 126-27, 139

Rūsiyyah/Rūs, 28-30 
Sacraments, 46, 98, 118, 120, 135

sacred/profane space 113-15, 118, 120-22, 136, 145, 91-100

contested spaces, 91-92, 94-95, 97, 100-101, 111

see also profaned space

sagnaskemmtun, 47

"Sakamaðurinn" (The Convict), 130n54

Sælingsdalur, 89, 91

Sæmundur fróði (the wise) Sigfússon, 4-5, 56-59, 104-6, 109, 117-18, 120, 123-34, 136, 138-39, 146-47

Sæmundur Magnússon Hólm, 63

"Sæmundur á banasænginni" (Sæmundur on his Deathbed), 131-33

Saurbæ, 23-24

Saxo Grammaticus, 5, 9

Skriver, Christian, 14

second sight see ófreskisgáfur

Sel, 67-68

“Sels-Móri eða Porgarður," 20, 67-70, 80

sending/-ar, 57n52, 60, 71-73, 81-86, $88,130 n 54$

Settlement of Iceland, 5, 39, 52, 91-95, 101, $103,138,143$

Seyðisfjörður, 91

ship burial, 28, 30; see also burial

Síðu-Hallur Porsteinsson, 76

Sigrún Hoqgnadóttir, 25-27

Sigurður Fáfnisbani, 27-28

"Sigurðarkviða in Skamma" (The Shorter

Lay of Sigurðr"), 27-31

Sigvarður Halldórsson (bishop), 14

Skaldic poetry, 9

Skálholt, 13-14, 105n60

Skeggi, son of Friðgerður, 39, 40n52, 41-43, 53, 64-65, 143; see also “Gullbrá og Skeggi i Hvammur"

Skildinganes, 68

"Skollabrækur" (The Devil's Underpants), 107

skotta/-ur, 77n42, 77-79, 83-86; see also individual folktales about

Skúli Gíslason, 104-6, 120n11,123n19

Snæfellsnes, 59, 88, 95
Sögupættir (Gísli Konráðsson) 104

sorcerers see galdramaður

soul

concepts of, 37, 104-5, 109, 111, 113

in deal with Devil, 113, 118-21, 123,130

eternal, 37, 58, 131-36, 145

as fylgja, 74-75, 77-78, 81-86, 144

see also húgr, aðsókn

Stefnir Porgilsson, 63

stjúpusögur (stepmother tales) 52 n34

Stokkseyrar-Dísa (Pórdís Markúsdóttir), 60

Stóridómur (Great Verdict), 16, 31

Straumfjarðar-Halla (Halla of

Straumfjörður), 58-59

Sturla Pórðarson, 51, 135

Sturlunga saga, 48-49, 77, 135

Sviðholt, 68-69

"Sweet William's Ghost," 25

Systrastapi, 102-3

Tabernacle, 97-98

tale types

ATU 325: The Sorcerer's Apprentice, 118, 130n55

ATU 326: The Youth Who Wanted to Learn What Fear Is, 118

ATU 330 The Smith and the Devil, 118-19, 123

ATU 365: The Dead Bridegroom Carries off his Bride, 23-25, 29-31, 35-38, $43,142,145$

ATU 810A* The Priest and the Devil, 118

ATU811: The Man Promised to the Devil Become a Clergyman, 118

ML 3000: The Black School, 109n77, 127-28, 136

ML 4000: Soul of a Sleeping Person Wanders on its Own, 81

Theodoricus Monachus (Pórir munkur), 9 Tómas Pórðarson (reverend), 59

“Tornæmi Drengurinn og Kölski” (The Stupid Boy and the Devil), 20, 117-18, 138

Trinity, Holy, 49 
trolls, 15, 21, 39-42, 52-54, 60-65, 121-22, 143

troll sphere, 53-54, 63-65, 143

Tungustapi

as contested space, 111, 113-15, 127,145

folktale about, 20-21, 89-94, 97, 103n52 "Tvær sagnir um fylgjur" (Two Stories about Fylgjur), 81-82

Ullarvötn (Wool Lakes), 45-46; see also "Álfkonan hjá Ullarvötn"

unconsecrated ground, 43, 95; see also profaned space

"Útisetur á Krossgötum" (Sitting out at the Crossroads), 107

Valbjörg (elf woman), 45-46, 61-65, 143 Valgerður Jónsdóttir (informant), 20n80, 67n1

Valkyrie, 25, 27, 49n22, 56, 74

vanapagan (Old Boy, Stupid Devil), 119

Vandrád/-ur, 45, 63, 147

Vanir, 107

"Vatnsburður Kölska" (The Devil Carries Water), 130

vestments, 89, 117-20

Vídalínspostilla (Jón Vídalín) 33-34, 44, 112-13

Vísnabók Guðbrands (Guðbrandur Porláksson), 16, 47n7

Viðey, 13-14

Virgin Mary 62

Volga River, 28

Völsunga saga, 48

von Minden, Didrich, 13, 100-101
Welsh folk tradition, 61

white witch, 58

William of Malmesbury:

De Gestis Regum Anglorum, 125, 131-32

witch burnings, 54-55, 103

witchcraft see galdramaður

witches, European, 56-57

witch hunts, 55-60; see also Malleus

Maleficarum

Ynglinga saga, 85

Pangbrandur Vilbaldússon, 39n50, 40n51, 48

"Peir koma pá fjórir" (They Come then Four), 81-82

piðranda páttr ok Pórhalls, 76, 88, 109-10, $113,134,144$

pjóð- (national-), 19

pórður Bjarnason, 69

Pórður Guðbrandsson, 135

Porgarður, Móri of Sel, 68-71, 79, 80, 84, 86-86; see also "Sels-Móri eða porgarður"

Porgerður Eyjólfsdóttir, 69, 80, 87

Porgerður Jónsdóttir, 68

Porlákur Runólfsson (bishop), 4-5

porlákur Skúlason (bishop), 112

Porlákur Pórarinsson (reverend), 36-38, 144

Pórólfur Móstrarskegg, 95-97, 99

Porsteins saga Víkingssonar, 76

porvalds páttr ens víðforla, 48

Porvaldur Koðránsson, 39n50, 48

puríður Bjarnadóttir, 68-69, 80, 87 